\begin{abstract}
UNIVERSIDADE DE SÃO PAULO
FACULDADE DE FILOSOFIA, LETRAS E CIÊNCIAS HUMANAS

DEPARTAMENTO DE HISTÓRIA

PROGRAMA DE PÓS-GRADUAÇÃO EM HISTÓRIA ECONÔMICA
\end{abstract}

FERNANDO FURQUIM DE CAMARGO

O Brasil e a Guerra Civil Espanhola: fluxos econômicos e negociações oficiosas (1936-1939) 


\author{
UNIVERSIDADE DE SÃO PAULO \\ FACULDADE DE FILOSOFIA, LETRAS E CIÊNCIAS HUMANAS \\ DEPARTAMENTO DE HISTÓRIA \\ PROGRAMA DE PÓS-GRADUAÇÃO EM HISTÓRIA ECONÔMICA
}

\title{
O Brasil e a Guerra Civil Espanhola: fluxos econômicos e negociações oficiosas (1936-1939)
}

Fernando Furquim de Camargo

Tese apresentada ao Programa de PósGraduação em História Econômica do Departamento de História da Faculdade de Filosofia, Letras e Ciências Humanas da Universidade de São Paulo para obtenção do título de Doutor em História Econômica.

Orientador: Prof. Dr. Lincoln Ferreira Secco

SÃO PAULO

2016 
Autorizo a reprodução e divulgação total ou parcial deste trabalho, por qualquer meio convencional ou eletrônico, para fins de estudo e pesquisa, desde que citada a fonte.

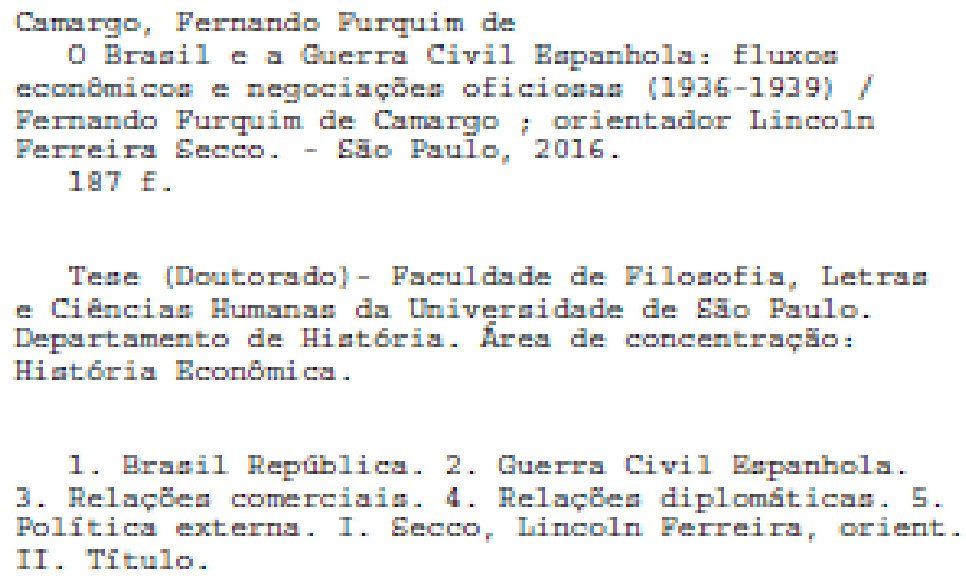


Nome: CAMARGO, Fernando Furquim de Camargo

Título: O Brasil e a Guerra Civil Espanhola: fluxos econômicos e negociações oficiosas (19361939)

Tese apresentada ao Programa de Pós-Graduação em História Econômica do Departamento de História da Faculdade de Filosofia, Letras e Ciências Humanas da Universidade de São Paulo para obtenção do título de Doutor em História Econômica.

Aprovado em:

\section{Banca Examinadora}

Prof. Dr.

Julgamento:

Prof. Dr.

Julgamento:

Prof. Dr.

Julgamento:

Prof. Dr.

Julgamento:

Prof. Dr.

Julgamento:
Instituição:

Assinatura:

Instituição:

Assinatura:

Instituição:

Assinatura:

Instituição:

Assinatura:

Instituição:

Assinatura: 
À Giovanna, meu grande amor e incansável apoiadora deste trabalho. Ao meu pai, Othoniel, por quem foi e pelo que representa.

À minha mãe, Lourdes, pelo constante apoio aos estudos. 


\section{Agradecimentos}

Ao Programa de Pós-Graduação em História Econômica que permitiu o desenvolvimento desta pesquisa de doutorado. E aos professores com quem tive contato e travei diálogos.

À Pró-Reitoria de Pós-Gradução pela concessão de auxílio de pesquisa no decorrer do doutoramento.

Aos camaradas do GMARX que apoiaram de forma contundente e ao mesmo tempo fraterna a elaboração desta pesquisa. Significante parcela das discussões surgiu dos encontros e discussões travados. Em especial: Ana Carolina Ramos, André Amano, Ciro Yoshiyasse, Felipe Lacerda, Fernando Sarti Ferreira, Rosa Gomes e Vivian Ayres. Estendo a todos os outros membros também o meu agradecimento.

Amplio o meu agradecimento ao André Amano que topou a empreitada de revisar o texto em condições adversas e urgentes.

Ao Prof. Dr. Wilson do Nascimento Barbosa pelo diálogo e ensinamentos durante todo o período de pesquisa.

Aos amigos Antonio Rago Filho e José Rodrigues Mao Junior pela contribuição no momento da qualificação.

Aos Professores do curso de Relações Internacionais da Universidade Federal do Tocantins. Em especial: Ana Lucia Gomes Muniz, Carlos Frederico P. da Gama e Silva, Fabiana Scoleso, Fernando José Ludwig, Ítalo Beltrão Sposito, José Pedro Cabrera Cabral e Rodolfo Ilário. A estes agradeço o suporte que deram nos momentos difíceis.

Aos colegas e professores da PUC-SP onde esse trabalho teve seu ponto de partida há 12 anos atrás. Às amigas Andrea e Vanessa e ao Prof. Dr. Antonio Pedro Tota, com quem dei largos passos com esta pesquisa.

Aos colegas e amigos da Unicastelo, que sempre se importaram e se interessaram, principalmente: Maria Candelaria, Sandra Colucci, Alberto, Juliana Monteiro, Washington Kuklinski e Talita Molina.

A todos meus atuais e ex-alunos que sempre se interessaram pela pesquisa aqui desenvolvida. Inclusive, agradeço a compreensão que sempre tiveram nos momentos de ausência e de insuficiente atenção.

Aos funcionários do Arquivo Histórico do Itamaraty, Archivo General de la Administración, Archivo del Ministerio de Asuntos Exteriores, National Archives and Records Administration, que auxiliaram de forma decisiva a coleta e quando necessário o envio transatlântico de fontes. Também agradeço aos funcionários das bibliotecas visitadas que sempre facilitaram a obtenção das obras.

Meus profundos agradecimentos ao Prof. Dr. Lincoln Secco, que acolheu o tema desta pesquisa para orientação e o apoio nos momentos críticos do desenvolvimento do trabalho. As 
reuniões em seu gabinete, às sextas-feiras, sempre trouxeram contribuições decisivas para a feitura deste doutoramento.

Aos meus familiares e amigos que acompanharam todo o processo deste trabalho.

Em especial ao meu pai, Othoniel, homem inigualável que me ensinou a doçura do viver. E, à minha mãe, Lourdes, que sempre estimulou o estudo.

À Giovanna Calabria, companheira e amor maior, que apoiou de forma inabalável a realização desta pesquisa. Não tenho palavras para agradecer o suporte essencial mesmo nos momentos da distância e da solidão na escrita. Te quiero.

Certamente, em um trabalho de tanta duração, muitos que compartilharam das preocupações não foram aqui citados nominalmente. Mas podem ter certeza que todos são amigos e com certeza colaboraram para o seu término. Meu abraço e muito obrigado.

Embora tenha tido muita contribuição, erros podem estar presentes, mas são de minha responsabilidade.

São Paulo, julho de 2016 


\section{RESUMO}

CAMARGO, F. F. de. O Brasil e a Guerra Civil Espanhola: fluxos econômicos e negociações oficiosas (1936-1939). $187 \mathrm{f}$. Tese (Doutorado) - Faculdade de Filosofia, Letras e Ciências Humanas, Universidade de São Paulo, São Paulo, 2016.

O objetivo desta pesquisa é analisar as relações entre o governo brasileiro e a Guerra Civil Espanhola. A partir da sublevação militar de 17 de julho de 1936, o cenário interno do estado espanhol tornou-se o epicentro do embate entre as forças conservadoras e a diversidade de grupos políticos de esquerda. Desde os seus primeiros momentos, a guerra civil transbordou as fronteiras espanholas e europeias. Se por um lado houve o envolvimento direto e indireto de países europeus, por outro, também houve substancial importância nas Américas. Assim, esta tese pretende desenvolver uma abordagem dos papéis existentes entre os órgãos públicos e privados relacionados ao governo Vargas e os grupos envolvidos na Guerra Civil Espanhola, sobretudo aqueles pertencentes aos militares sob o controle de Francisco Franco. As ações de órgãos como o Ministério de Relações Exteriores e do Departamento Nacional do Café, tiveram papel preponderante em um apoio oficioso aos rebelados, enquanto que as representações diplomáticas da Segunda República foram paulatinamente relegadas a uma situação marginal.

Palavras-chave: Brasil. Espanha. Guerra Civil Espanhola. Relações comerciais. Relações diplomáticas 


\begin{abstract}
CAMARGO, F. F. de. Brazil and the Spanish Civil War: economic flows and unofficial negotiations (1936-1939). $187 \mathrm{f}$. Tese (Doutorado) - Faculdade de Filosofia, Letras e Ciências Humanas, Universidade de São Paulo, São Paulo, 2016.

The aim of this research is to analyze the relations between the Brazilian government and the Spanish Civil War. From the military uprising of 1936 July 17th, the domestic scenery of Spanish State became the epicenter of a struggle between conservative forces and the diversity of left political groups. Since its first moments, the civil war crossed the Spanish and European borders. If, on the one hand, there was a direct and indirect involvement of the European countries, on the other hand, there was also a substantial significance in the Americas. Thus, this thesis intends to develop an approach between the roles of public and private organizations of Vargas government and the related groups of the Spanish Civil War, mainly those ones under the General Francisco Franco's control. The attitudes of public bodies as the Brazilian Ministry of Foreign Affairs and National Coffee Department, it had a key role to an unofficial support to the insurgents, meanwhile, the diplomatic representations of Spanish Second Republic were gradually sent to a marginal condition.
\end{abstract}

Keywords: Brazil. Spain. Spanish Civil War. Commercial relations. Diplomatic relations. 


\section{RESUMÉN}

CAMARGO, F. F. de. El Brasil y la Guerra Civil Española: flujos económicos y las negociaciones oficiosas (1936-1939). $187 \mathrm{f}$. Tese (Doutorado) - Faculdade de Filosofia, Letras e Ciências Humanas, Universidade de São Paulo, São Paulo, 2016.

El blanco de esa investigación es analizar las relaciones entre el gobierno brasileño y la Guerra Civil Española. A partir de la sublevación militar del 17 de julio de 1936, el escenario interno del estado español se volcó en el epicentro del embate entre las fuerzas conservadoras y la diversidad de grupos políticos de izquierda. Desde sus primeros momentos, la guerra civil trasbordó las fronteras españolas y europeas. Si por un lado hubo en envolvimiento directo e indirecto de los países europeos, por el otro, también hubo una sustancial importancia en las Américas. Así, esa tesis tiene la intención de desarrollar un abordaje de las relaciones entre los órganos públicos y privados del gobierno Vargas y los bandos envueltos en la Guerra Civil Española, sobre todo aquellos pertencientes a los militares bajo el control del General Francisco Franco. Las acciones de órganos como el Ministerio de Asuntos Exteriores y del Departamento Nacional del Café, tuvieron preponderantes papeles en un apoyo oficioso a los rebelados, mientras tanto, las representaciones diplomáticas de la Segunda República fueron paulatinamente puestas a una situación marginal.

Palabras-clave: Brasil. España. Guerra Civil Española. Relaciones comerciales. Relaciones Diplomáticas. 


\section{LISTA DE QUADROS, TABELAS E GRÁFICOS}

Gráfico 1 - Brasil-Espanha: Números Absolutos de Importações e Exportações (1929-1939)..... 25

Tabela 1.1 - Membros da Junta de Defensa Nacional (24/07/1936 - 03/10/1936)...................... 47

Tabela 1.2 - Atribuições da Junta Técnica del Estado (03/10/1936-31/01/1938) .......................... 50

Tabela 1.3 - Membros da Junta Técnica del Estado (03/10/1936-31/01/1938) ............................ 51

Tabela 1.4 - Primeira Composição do Gobierno de Burgos (31/01/1938) ................................ 53

Tabela 1.5 - Junta Oficial Nacionalista Española en el Brasil ............................................... 71

Tabela 2.1. Distribuição geográfica do comércio exterior espanhol (1827-1913). Principais países

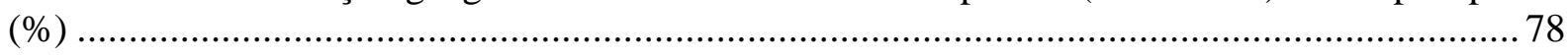

Tabela 2.2 - Comparação do comércio espanhol com os países latino-americanos (1931) - (\%) 79

Tabela 2.3 - Média quinquenal da participação brasileira no comércio externo espanhol. Porcentagem em relação ao total comercializado pela Espanha (1929-1935) ............................. 81

Tabela 2.4 - Comércio do Brasil com a Espanha (1931-1935) ................................................. 82

Tabela 2.5 - Participação das relações comerciais com a Espanha. Porcentagem em relação ao total

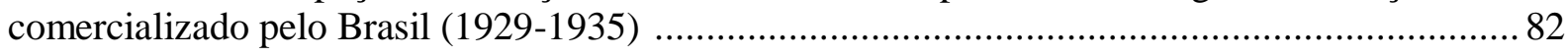

Tabela 2.6 - Prospecção espanhola para comércio com o Brasil (1935) ..................................... 84

Tabela 2.7 - Exportação de Café para áreas sob controle do Estado espanhol, 1935-1936. (Em sacas

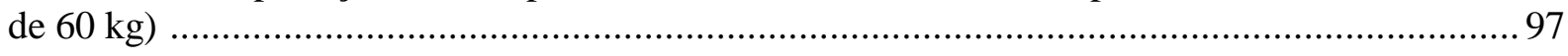

Tabela 2.8 - Variação mensal de exportação de Café, 1936. (Em sacas de 60 kg) ...................... 97

Tabela 2.9 - Variação mensal de exportação de Café, 1937. (Em sacas de $60 \mathrm{~kg}$ ) ...................... 99

Tabela 2.10 - Embarques de Café: Brasil-Espanha entre julho de 1936 e junho de 1937 (Em sacas

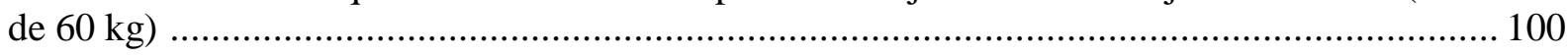

Tabela 2.11 - Variações mensais de exportação de Café para Portugal, 1936-1937. (Em sacas de 60

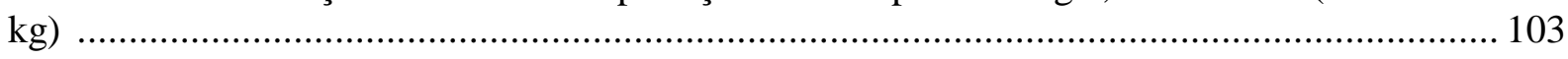

Tabela 2.12 - Importações e exportações de Café por Portugal, 1936-1937. (Em kg) ............... 105

Tabela 3.1 - Variações mensais de exportação de Café, 1937-1938 (Em sacas de 60 kg) .......... 132

Gráfico 2 - Brasil-Espanha: resumo das importações e exportações (1931-1945) .................... 149

Tabela 3.2 - Exportação de Café para a Espanha (1939-1945)................................................ 150 


\section{LISTA DE ABREVIATURAS E SIGLAS}

AGA $=$ Archivo General de la Admistración

AGGC $=$ Archivo General de la Guerra Civil

$\mathrm{AIB}=\mathrm{Ação} \mathrm{Integralista} \mathrm{Brasileira}$

$\mathrm{AHI}=$ Arquivo Histórico do Itamaraty

AMAE $=$ Archivo del Ministerio de Asuntos Exteriores

$\mathrm{AN}=$ Arquivo Nacional

ANL $=$ Ação Nacional Libertadora

$\mathrm{AB} / \mathrm{MF}=$ Arquivo e Biblioteca do Ministério da Fazenda

CAMPSA = Compañia Arrendataria del Monopolio del Petróleo S.A.

CEDA $=$ Confederación Española de Derechas Autonómas

CNT = Confederación Nacional del Trabajo

COMINTERN = Internacional Comunista

CPDOC/FGV = Centro de Pesquisa e Documentação de História do Brasil da Fundação Getúlio

Vargas

DNC $=$ Departamento Nacional do Café

FDR/PL = Franklin Delano Roosevelt Presidential Library

FET $=$ Falange Española Tradicionalista

FET y de las JONS = Falange Española Tradicionalista y de las Jornadas Ofensivas Nacional-

Socialistas

FRUS $=$ Foreign relations of the United States

HISMA = Hispano-Marroquí de Transporrte, S.L.

IBGE = Instituto Brasileiro de Geografia e Estatística

$\mathrm{INE} / \mathrm{BR}=$ Instituto Nacional de Estatística (Brasil)

$($ J.N.E.E.B) $=$ Junta Nacionalista Española en el Brasil

MRE = Ministério de Relações Exteriores

NARA/I = National Archives and Records Administration (Washington, D.C.)

NARA/II = National Archives and Records Administration (College Park, MD)

OSS $=$ Office of Strategic Services

$\mathrm{PCE}=$ Partido Comunista Español

POUM = Partido Obrero de Unificación Marxista

$\mathrm{PP}=$ Partido Popular 
PRR $=$ Partido Republicano Progresista

PSOE $=$ Partido Socialista Obrero Español

ROWAK = Rohstoff-und-Wareneinkausfsgesellschaft m.b.G

TEXACO $=$ Texas Oil Company

UGT = Unión General de Trabajadores

UP = Unión Patriótica 


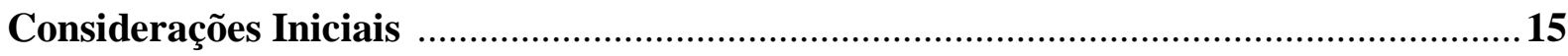

1. A Guerra Civil Espanhola: dos antecedentes à composição sublevada ........................29

1.1 Segunda República Espanhola: reformismo, conservadorismo e guerra ......................29

$1.2 \mathrm{O}$ estado paralelo sublevado: da militarização inicial à via espanhola do fascismo .......44

1.3 Sublevados: dinâmica interna e o apoio externo nos campos militar e econômico ........54

1.4 Os diplomatas contra a República: o surgimento da representação sublevada ..............63

2. O Brasil e o cenário inicial: posicionamento e interferências externas (1936-1937) ...76

2.1 A pífia trajetória das relações comerciais hispano-brasileiras na Segunda República ..76

2.2 Embates internos e influências externas no posicionamento brasileiro ..........................88

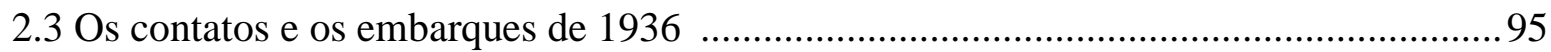

2.4 Estados Unidos: posicionamento e propostas continentais ........................................ 106

3. O adeus à República Espanhola: alinhamento e reconhecimento do Estado franquista

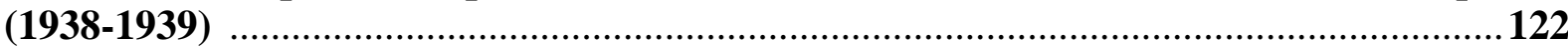

3.1 O Estado Novo no Brasil: esmorecimento republicano e fortalecimento sublevado.... 122

3.2 Os embarques de 1938: as interferências explícitas do Departamento Nacional do Café

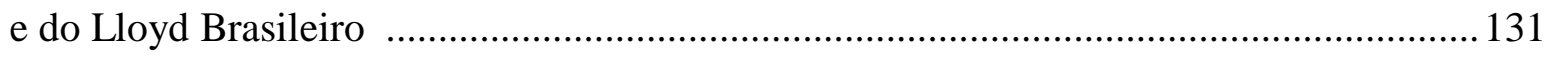

3.3 A Exposição Anticomunista e o ataque ao governo republicano ................................ 140

3.4 O fim da Guerra Civil Espanhola: o reconhecimento e a retomada do comércio hispano-

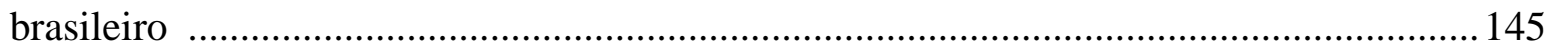

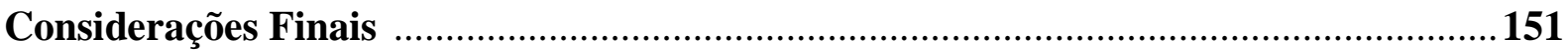

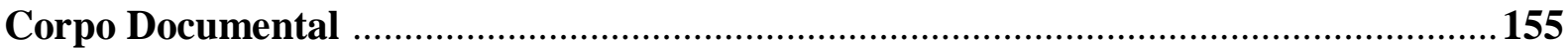

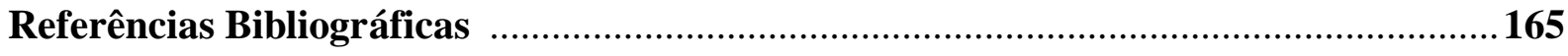

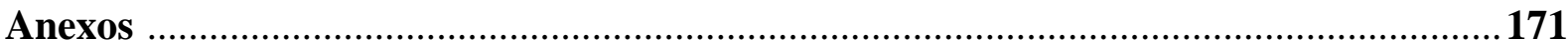




\section{Considerações Iniciais}

Ao folhear jornais espanhóis entre 2015 e 2016, uma boa parcela das notícias está concentrada nos seguintes temas: a situação econômico-social espanhola derivada da crise mundial iniciada em 2008, o enfraquecimento da polarização política entre o Partido Socialista Obrero Español (PSOE) e o Partido Popular (PP), o surgimento do Podemos e Ciudadanos e as negociações acerca do processo independentista da Catalunha. Embora em algumas circunstâncias, as apresentações de universalidades podem provocar imprecisões em análises políticas e econômicas, de forma indireta, esses temas são caudatários da própria condição do Estado espanhol atual: após 80 anos do início da sublevação militar de 17 de julho de 1936, os seus desdobramentos militares, políticos, econômicos e sociais dos três anos seguintes de peleja militar são indissociáveis da condição espanhola contemporânea.

Assim, de chofre, a própria condição atual espanhola justificaria o surgimento de uma pesquisa que retomasse algum nível de abordagem acerca do conflito ocorrido entre 1936 e 1939. No entanto, a elaboração e a constituição de um processo de pesquisa sobre o tema, ao menos no nosso trabalho, possuem raízes deitadas que vão além do presente e que envolvem as condições endógenas e exógenas da Guerra Civil, as "clássicas" e atuais abordagens historiográficas sobre o tema e hipóteses que podem trazer alguma contribuição. Dentro dos limites de uma tese de doutoramento e da própria impossibilidade de se esgotar as problemáticas do período, acreditamos que as circunstâncias que envolvem a Guerra Civil Espanhola são pertinentes para o desenvolvimento de uma nova pesquisa sobre o período.

No mesmo diapasão, encontram-se as possibilidades de encarar o período varguista, mesmo com a vasta historiografia e as constantes produções sobre o período entre 1930 e 1939. Em tempos de investidas conservadoras e reacionárias contra os trabalhadores no cenário brasileiro atual, acreditamos que é pertinente se aproximar dos contatos e os choques de tendências reformistas, conservadoras e de esquerda como foi o caso brasileiro na década de 1930.

Assim, das preocupações atuais e da nossa própria trajetória se desenvolveu esta pesquisa de doutoramento. Os delineadores temporais e espaciais surgiram ainda no decorrer da dissertação de mestrado ${ }^{1}$, que problematizou o ideário do fundador da Falange Española Tradicionalista (FET), José Antonio Primo de Rivera. No interior de sua composição

\footnotetext{
${ }^{1}$ CAMARGO, Fernando Furquim de. O Ideário Falangista de José Antonio Primo de Rivera (1931-1936). São Paulo, 2002. 262 f. Dissertação (Mestrado em História) - Programa de Estudos Pós-Graduados em História, Pontifícia Universidade Católica de São Paulo. O trabalho foi desenvolvido no Programa de Estudos PósGraduados em História da PUC-SP, sob orientação do Prof. Dr. Antonio Rago Filho.
} 
ideológica, alguns nexos que permeavam as forças tradicionais, como a manutenção do agrarismo como forma predominante do sistema produtivo espanhol, o anti-industrialismo e antiliberalismo, ademais das propostas de retomada do status colonial de suas antigas possessões nas américas. Deste último quesito, emergiu questionamentos a respeito das relações entre o Brasil e a Segunda República Espanhola (1931-1936).

As percepções iniciais sobre a ausência de análises sobre contatos bilaterais entre a Espanha e o Brasil tornaram-se o ponto de partida para a elaboração de um projeto de doutoramento para o ingresso no Programa de Estudos Pós-Graduados em História da Pontifícia Universidade Católica de São Paulo (PUC-SP). Durante a minha permanência na PUC-SP, entre os anos de 2006 e 2009, ${ }^{2}$ a pesquisa se restringia à análise dos contatos hispano-brasileiros por meio do viés da política.

No entanto, a partir do Ingresso no Programa de Pós-Graduação em História Econômica do Departamento de História da Faculdade de Filosofia, Letras e Ciências Humanas da Universidade de São Paulo (HE-FFLCH/USP), algumas problemáticas no campo das relações econômicas hispano-brasileiras tomaram corpo e protagonismo no desenvolvimento do trabalho.

Sem descurar do que já havia sido previamente abordado durante os anos de PUC-SP, o desenvolvimento da tese inclinou-se para abordar os contatos econômicos entre o Estado brasileiro e os atores de ambos os campos, republicanos e militares sublevados, durante a Guerra Civil Espanhola. Em concomitância com as justificativas iniciais acima expostas, a historiografia acerca da Guerra Civil Espanhola ${ }^{3}$ e das relações entre Brasil e Espanha nos apresentou uma série de lacunas e questionamentos que serão desenvolvidos no decorrer deste trabalho.

O conjunto de obras que abordam o conflito espanhol e seus contatos bilaterais se concentra nas relações dos militares sublevados com a Alemanha e a Itália, a participação direta e indireta dos Estados Unidos e as negociações do governo republicano junto à Inglaterra e França, bem como no âmbito do Comitê de Não-Intervenção criado em Londres após o início do conflito. Ressaltam-se também as diversas obras sobre as relações entre o governo espanhol

\footnotetext{
${ }^{2}$ Durante a fase puquiana deste trabalho, a orientação esteve à cargo do Prof. Antonio Pedro Tota.

${ }^{3}$ Existe uma vasta quantidade de livros, artigos e trabalhos acadêmicos sobre a Guerra Civil Espanhola. Não é nossa pretensão esgotar a sua apresentação ou as discussões existentes. No entanto, acreditamos que é relevante apresentar um corpo bibliográfico que dá sustentação a grande parte dos trabalhos, além das obras que estão interligadas com o desenvolvimento desta pesquisa.
} 
da Frente Popular e a União Soviética, principalmente em torno da ajuda militar e ao "Ouro de Moscou".

Em seus aspectos mais amplos, ao abordar as relações dos múltiplos atores e cenários acima citados, construiu-se um gradiente de análises que realizam uma mão-dupla na qual transitam as participações no conflito e as determinações históricas internas do Estado e da sociedade espanhóis dos anos de 1930. Entre a imensa quantidade de publicações que constituem a base da crítica ou sustentação, estão obras coautorias e individuais de Pierre Broué$^{4}$, Emile Témine ${ }^{5}$, Manuel Tuñon de Lara ${ }^{6}$, Javier Tusell ${ }^{7}$, Gabriel Jackson ${ }^{8}$ e Ramón Tamames ${ }^{9}$.

Nos anos mais recentes, especialmente nas proximidades do $70^{\circ}$ aniversário do início do conflito, em 2006, um novo conjunto de obras foram publicadas. Entre aquelas que tomaram destaque, encontram-se a de Antony Beevor ${ }^{10}$ e uma trilogia de Angel Viñas. ${ }^{11} \mathrm{Na}$ abordagem sobre o desenrolar da Guerra Civil e a vitória do exército rebelado em 1939 nas suas relações com a América Latina, destacam-se os textos de Lorenzo Delgado Gómez-Escalonilla ${ }^{12}$ e outras obras coletivas $^{13}$, que trazem aportes nos capítulos que as compõe.

Ao abordar as questões materiais e econômicas no Estado espanhol e no decorrer da Guerra Civil Espanhola, um dos pontos de referência foi as obras de Pierre Vilar. O historiador francês, a partir de suas análises sobre a circulação de moeda e capital tanto na Espanha, ${ }^{14}$ como

\footnotetext{
${ }^{4}$ BROUÉ, Pierre. A Revolução Espanhola, 1931-1939. São Paulo: Perspectiva, 1992.

${ }_{5}^{5}$ BROUÉ, Pierre; TÉMINE, Emile. La Revolución y la guerra de España. Mexico D.F.: Fondo de Cultura Económico, 1989.

${ }^{6}$ TUÑON DE LARA, Manuel. La II República. Madrid: Siglo Veintiuno, 1976.

${ }^{7}$ Embora em suas publicações mais recentes Tusell tenha enveredado por abordagens mais liberais e em alguns momentos mais próxima da neofranquista, suas obras mais antigas ainda são dignas de leitura: TUSELL, Javier. El regimen de Franco (1936-1975). Madrid: UNED, 1993.

${ }^{8}$ JACKSON, Gabriel. La República española y la Guerra Civil. 2a. Ed. Barcelona: Grijalbo, 1976.

${ }^{9}$ TAMAMES, Ramón. La República/La Era de Franco. Madrid: Alfaguara/Alianza Editorial, 1979.

${ }^{10}$ BEEVOR, Antony. La Guerra Civil Española. Barcelona: Crítica, 2005.

${ }^{11}$ VIÑAS, Angel. El escudo de la República. El oro de España, la apuesta soviética y los hechos de mayo de 1937. Barcelona: Crítica, 2010; VIÑAS, Angel. El honor de la República. Entre o acoso faccioso, la hostilidade britânica y la política de Stalin. Barcelona: Crítica, 2010; VIÑAS, Angel. La Soledad de la República. El abandono de las democracias y el viraje hacia la Unión Soviética. Barcelona: Crítica, 2010.

${ }^{12}$ GÓMEZ, ESCALONILLA, Lorenzo D. Diplomacia franquista y política cultural hacia Iberoamerica, 19391953. Madrid: Consejo Superior de Investigaciones Científicas, 1988; GÓMEZ, ESCALONILLA, Lorenzo D. Imperio de papel. Acción cultural y política exterior durante el primer franquismo. Madrid: Consejo Superior de Investigaciones Científicas, 1992.

${ }^{13}$ TUSELL, Javier et al. La política exterior de España em el siglo XX. Madrid: UNED, 2000; CERVANTES, Ángel; PEREIRA, Juan Carlos. Relaciones Diplomáticas entre España y America Latina. Madrid: Editorial Mapfre, 1992.

${ }^{14}$ VILAR, Pierre. Crecimiento y Desarrollo. Economia e historia. Reflexiones sobre el caso español. Barcelona: Ariel, 1983.
} 
de forma universalizada ${ }^{15}$, o profundo estudo sobre a Catalunha ${ }^{16}$ e sua pioneira análise sobre o conflito espanhol. ${ }^{17}$ Nesta última, surge um fio condutor argumentativo que Vilar conceitua como os "dois campos", em que dialoga com as múltiplas formas do espaço espanhol durante o conflito ao balizar as ações dos militares revoltosos, do governo republicano e dos movimentos operários que apresentaram resistência de forma autônoma.

As análises sobre o caráter econômico da Segunda República e da Guerra Civil possuem dois parâmetros: um deles é o que compreende o período entre o surgimento do novo regime em 1931 e o início da Guerra Civil em julho de 1936, com o sistema estatístico espanhol possuía pleno funcionamento, com a publicação anual da atividade econômica; e o segundo é o que está inserido dentro do lapso temporal do conflito espanhol, quando a periodicidade e mesmo a coleta de dados esteve prejudicada. ${ }^{18}$ Ou seja, obras que analisam os primeiros cinco anos republicanos possuem dados consolidados, com os questionamentos surgidos no espaço da Guerra.

Ainda no final da década de 1970, uma das pioneiras e mais extensivas obras a respeito das relações comerciais externas espanhola, organizada por Angel Viñas, já trazia advertências do caráter fragmentado e da confiabilidade das estatísticas do período da Guerra Civil. ${ }^{19}$ Embora essa problematização tenha surgido prontamente nos primeiros anos após o fim da Ditadura franquista, somente nas décadas seguintes é que houve um aprofundamento na temática, por meio de ensaios que confrontavam as estatísticas disponíveis e as metodologias até então adotadas. ${ }^{20}$

As circunstâncias da incompletude dos dados de atividade econômica envolvem a própria fragmentação e divisão do Estado espanhol com a Guerra. Com o início do conflito, as publicações que possuíam o título de Anuario Estadístico de España têm a sua última edição

\footnotetext{
15 VILAR, Pierre. Oro y moneda en la historia (1450-1920). $3^{\text {a }}$. Ed. Barcelona: Ariel, 1974.

16 Idem. La Catalogne dans l'Espagne moderne: recherches sur les fondements économiques des structures nationales. Paris: S.E.V.P.E.N., 1962.

${ }^{17}$ Idem. La guerra civil española. $5^{\text {a }}$. Ed. Barcelona: Crítica, 2005.

${ }^{18}$ Os anuários econômicos do estado espanhol estão disponíveis em fac-símile, a partir da edição de 1858 , no site do Instituto Nacional de Estadística (INE). Disponível em:

$<$ http://www.ine.es/prodyser/pubweb/anuarios_mnu.htm>. Acesso em: 30 dez. 2015.

${ }_{19}$ VIÑAS, Angel et al. Política Comercial Exterior em España (1931-1975). Madrid: Banco Exterior de España, 1979,2 vols.

${ }^{20}$ TENA, Antonio J. Las estadísticas históricas del comércio internacional: fiabilidade y comparabilidade (18901960). Estudios de Historia Económica, no. 24. Madrid: Banco de España - Servicios de Estudios, 1992. Em 2006 uma nova reconstrução de dados estadísticos do comércio exterior espanhol foi realizado, mas com ênfase no período entre 1936 e 1939: MARTINEZ RUIZ, Elena. Guerra Civil, Comercio y Capital Extranjero. El sector exterior de la economía española (1936-1939). Estudios de História Económica, no. 49. Madrid: Banco de España, 2006.
} 
em maio. ${ }^{21}$ As publicações seriadas somente foram retomadas em 1943, já sob a Ditadura de Franco, com os dados de 1935 e a partir de $1940^{22}$ e com isso, as únicas compilações de dados originados do próprio território espanhol são os relatórios provisórios feitos pela Segunda República em 1936 e $1938 .^{23}$

As reflexões que analisam a participação de brasileiros na Guerra Civil e do governo varguista se dividem essencialmente em dois pontos. O primeiro deles é o conjunto de obras de cunho memorialista e que estão concentradas em atuações nas fileiras das Brigadas Internacionais. ${ }^{24}$ Em grande medida, esses artigos e trabalhos acadêmicos se utilizam das memórias de José Gay da Cunha e de Apolônio de Carvalho. ${ }^{25}$

A respeito das obras sobre as relações do governo brasileiro com a Guerra Civil, a quantidade de publicações é extremamente restrita e com uma produção desenvolvida no decorrer dos anos de 1980. Um dos primeiros trabalhos sobre as relações hispano-brasileiras foi o de Sandra Maria L. Brancato, que publicou um artigo pioneiro no qual abordava as relações entre o governo varguista, a partir do Estado Novo, e o regime republicano espanhol. ${ }^{26}$ Em seu texto, a autora fixa sua análise nos efeitos que a Embaixada espanhola sofreu, com o surgimento do regime estadonovista, com uma documentação centrada na correspondência entre o então Encarregado de Negócios espanhol no Brasil, Fernando Morales Llamas, o Ministério de Relações Exteriores do Brasil e o Ministério de Estado espanhol. Essencialmente, a problemática encontrava-se na forma como, a partir da criação do Estado Novo, a representação diplomática do Estado espanhol e outros órgãos vinculados aos cidadãos daqueles países foram sistematicamente reprimidos e fechados, principalmente pela vinculação, criada pelo governo de Vargas, do regime republicano espanhol como uma ameaça comunista.

\footnotetext{
21 ESPAÑA. MINISTERIO DE TRABAJO, SANIDAD, Y PREVISIÓN. SUBDIRECCIÓN GENERAL DE ESTADÍSTICA. Pequeño Anuario Estadístico de España. Madrid: Talleres Tipográficos PLUTARCO, 1936.

22 ESPAÑA. MINISTERIO DE TRABAJO. DIRECCIÓN GENERAL DE ESTADÍSTICA. Anuario Estadístico de España. Madrid, Año XX, 1943.

${ }^{23}$ ESPAÑA. Dirección General de Aduanas. Sección de Estadística. Resumen provisional de estadística del comercio exterior: enero a marzo de 1938. Madrid: Sucesores de Rivadeneyera, 1938; ESPAÑA. Dirección General de Aduanas. Sección de Estadística. Resumen provisional de estadística del comercio exterior: julio a deciembre de 1936. Madrid: Sucesores de Rivadeneyera, 1936.

${ }^{24}$ ALMEIDA, Paulo Roberto de. "Brasileiros na Guerra Civil Espanhola, 1936-1939” In: Revista de Sociologia e Política. Curitiba, UFPR, ano 4, no. 12, junho de 1999, pp. 35-66; BATTIBUGLI, Thaís. A militância antifascista: comunistas brasileiros na Guerra Civil Espanhola (1936-1939). São Paulo: Dissertação de Mestrado, Universidade de São Paulo, 2002; RODRIGUES, Pedro. "Brasileiros na Espanha" In: Temas das Ciências Humanas. São Paulo, volume 9, 1980, pp. 125-128.

${ }^{25}$ CUNHA, José Gay da. Um brasileiro na Guerra Civil. São Paulo: Alfa-Ômega, 1987; CARVALHO, Apolônio de. Vale a pena sonhar. Rio de Janeiro: Rocco, 1987.

${ }^{26}$ BRANCATO, Sandra Maria Lubisco. “As relações Brasil/Espanha na transição para o Estado Novo”. In: Estudos Ibero-Americanos, XIII (2), 1987, p. 151-160.
} 
Ainda naquele mesmo período, Carlos Sixirei Paredes ${ }^{27}$ também situa-se como um dos pioneiros nos estudos das relações entre Brasil e Espanha. Sendo subsequente ao fim dos regimes ditatoriais e com implementação dos regimes democrático-liberais em ambos os países, o autor traça um panorama em um recorte que vai da subida de Getúlio Vargas, em 1930, até a sua deposição em 1945.

Após um grande hiato, duas novas pesquisas vieram à tona e abordaram diretamente as relações entre o Brasil e a Espanha no decorrer do século XX. Embora ambos trabalhos possuam um recorte temporal e problemáticas que estão além daqueles que propomos, os doutoramentos de Ismara Izepe de $\mathrm{Souza}^{28}$ e de Bruno Ayllón Pino ${ }^{29}$ produziram novas reflexões sobre os contatos bilaterais entre ambos os países.

No caso de Souza, o seu trabalho tem como fio uma trajetória das relações hispanobrasileira entre 1936 e 1960. Em relação ao período da Guerra Civil Espanhola, embora concentrada apenas em um capítulo, a autora concentra a sua análise no papel do Ministério de Relações Exteriores do Brasil e sua postura anticomunista diante do conflito, além de refletir a respeito das condições do corpo diplomático brasileiro, o processo de reconhecimento do governo franquista pelo Brasil e a ascendência de Oswaldo Aranha sobre Getúlio Vargas a respeito do posicionamento do governo frente ao conflito. ${ }^{30}$

Embora a autora tenha desenvolvido em sua pesquisa uma acurada análise sobre as condições políticas do MRE, do posicionamento dos órgãos institucionais sobre os efeitos da Guerra Civil no Brasil e junto aos imigrantes espanhóis, algumas questões que não foram abordadas podem ser desenvolvidas e trazerem novas luzes sobre as relações entre Brasil e Espanha no período da Guerra Civil Espanhola. Entre as quais, a correspondência recebida por Vargas, e que teria sido enviada por Franco como agradecimento pelo envio de sacas de café e açúcar, e o próprio quadro geral das relações com as representações dos revoltosos em território brasileiro, como foram a Comisión Nacionlista Española e a Junta Nacionalista Española en el Brasil (J.N.E.E.B) no decorrer do conflito espanhol.

E, como citamos anteriormente, a outra produção relevante que traz reflexão sobre o tema e a esta pesquisa, é a de Ayllón Pino. Em seu doutoramento pela Universidad Complutense

\footnotetext{
27 SIXIREI PAREDES, Carlos. El Brasil de Vargas (1930-1945). Madrid: Tesis Doctoral, Universidad Complutense de 1988.

${ }^{28}$ SOUZA, Ismara Izepe de. Caminhos que se cruzam: relações históricas entre Brasil e Espanha (1936-1960). São Paulo, 2009. Tese (Doutorado em História Social) - Faculdade de Filosofia Letras e Ciências Humanas, Universidade de São Paulo.

${ }^{29}$ AYLLÓN PINO, Bruno. Las relaciones entre Brasil y España ponderadas desde la perspectiva de la política exterior brasileña (1979-2000). Madrid: Tesis Doctoral, Universidad Complutense de Madrid, 2004.

${ }^{30}$ SOUZA, Ismara Izepe de. op. cit., 2009, p. 28.
} 
de Madrid, o autor concentra em seu capítulo cinco o que ele conceitua como mútua irrelevância entre Brasil e Espanha. ${ }^{31}$ A trajetória apresentada pelo autor, que mostra uma longa linha das relações entre o Estado espanhol e as diversas formas governamentais desde o período colonial, se concentra estritamente no aspecto político desses contatos. Em relação ao cenário econômico das ligações entre os dois países, entre os anos de 1931 e 1936, e mesmo durante a Guerra Civil, da mesma forma que Souza, não apresenta uma análise direta dos seus contatos bilaterais.

A procura pelo corpora da Guerra Civil Espanhola padeceu das mesmas dificuldades e vantagens de se estabelecer problemáticas sobre o tema. Por um lado, a disponibilidade de uma imensidão de documentos que envolvem atores estatais, não-estatais, memórias publicadas, dados econômicos e coleções particulares; por outro, devido ao próprio caráter do conflito, a vasta disponibilidade documental encontra-se fragmentada em arquivos públicos e privados tanto na própria Espanha, bem como no exterior, como é o caso de arquivos, principalmente os pertencentes às políticas externas, na Alemanha, Estados Unidos, França, Itália, México, Reino Unido e Rússia, além do próprio Brasil. Dessa forma, da mesma sorte que a Guerra Civil se caracterizou como internacional desde os seus primeiros momentos, as localizações espaciais de sua documentação também tomaram esse caráter.

Ademais, no caso do corpus situado em território espanhol que sofreu os efeitos do fim do conflito, da Ditadura franquista e das disputas pela posse documental, principalmente as de origem catalã, após 1977, com o processo de democratização. ${ }^{32}$ Em nosso caso, os problemas encontrados situam-se no mesmo diapasão que o apresentado por Angel Viñas, quando este ressalta em três casos, em uma de suas obras mais recentes ${ }^{33}$, as dificuldades em abordar temas relacionados às questões econômicas do governo republicano e dos militares sublevados. Primeiro, a queima de vasta documentação da embaixada republicana em Moscou ao final da guerra. Em segundo lugar, as perdas e as destruições deliberadas ou involuntárias quando Madri foi tomada pelos sublevados e houve a transferência da sede do governo republicano para Valência e depois para Barcelona, quando uma grande quantidade de papéis relacionada à política externa comercial espanhola desapareceu durante o translado. E, por último, nos momentos finais da Ditadura franquista, no decorrer dos anos de 1970, com a eliminação de

\footnotetext{
${ }^{31}$ AYLLÓN PINO, Bruno. op. cit., 2004, p. 239-277.

${ }^{32}$ Com a Ley de Memória Historica De España (Ley 52/2007, de 26 de deciembre), além das resoluções a respeito do reconhecimento das vítimas da Guerra Civil e do Franquismo e da formação de grupos de trabalho sobre a questão da memória, também acentuaram as problemáticas acerca da documentação catalã situada no Archivo General de la Guerra Civil, em Salamanca. Em 2013, o judiciário espanhol decidiu pela restituição dos documentos da Generalitat ao governo catalão.

${ }^{33}$ VIÑAS, Angel. op. cit., 2006, p. xiv.
} 
materiais de origem republicana que estavam armazenados no Instituto Español de Moneda Estranjera (IEME), em Madri.

Dada as condições da pesquisa, dos objetivos e das problemáticas apresentadas, optamos pela visita em fundos documentais e bibliotecas situados nos Brasil, na Espanha e nos Estados Unidos; outrossim, também utilizamos vasta documentação primária impressa principalmente por organismos internacionais e por instituições estatais, muitas vezes situados nos próprios locais de pesquisa in loco:

\section{- Brasil}

Em relação às fontes de origem brasileira, os esforços se concentraram nos fundos documentais com registros sobre as políticas externas e internas do primeiro período em que Getúlio Vargas esteve à frente do Estado brasileiro (1930-1945). Assim, foram locais primários de pesquisa: o Centro de Pesquisa e Documentação de História do Brasil da Fundação Getúlio Vargas (CPDOC/FGV), o Arquivo Histórico do Itamaraty (AHI), o Arquivo Nacional (AN) e o Arquivo e Biblioteca do Ministério da Fazenda (AB/MF), todos localizados no Rio de Janeiro.

No CPDOC/FGV, os esforços foram concentrados nas correspondências, escritos e discursos de Getúlio Vargas, Oswaldo Aranha e de Alcebíades Peçanha, além de outros indivíduos que porventura tiveram participação direta, por meio do governo brasileiro, nas ações governamentais na Guerra Civil Espanhola. No AHI, onde se concentram os arquivos da diplomacia brasileira entre 1808 e 1959, nos dedicamos aos maços documentais relacionados às representações diplomáticas do governo brasileiro no Estado espanhol e grupamentos temáticos, como foi o caso daqueles pertencentes às negociações econômicas hispanobrasileiras. $\mathrm{E}$, no $\mathrm{AB} / \mathrm{MF}^{34}$, onde se concentra uma imensidão de publicações sobre o desempenho econômico brasileiro, doméstico e internacional, convergimos para a busca quantitativa de índices e estatísticas, com especial atenção à coleção publicada pelo Serviço de Estatística Econômica no decorrer dos anos de 1930 e 1940.

Além das publicações do Ministério da Fazenda localizadas no próprio local, a busca por publicações impressas se focou em bibliotecas públicas, privadas, universitárias e em sítios de internet que disponibilizam versões fac-símiles.

\footnotetext{
${ }^{34}$ De forma paulatina, está em curso a digitalização do acervo do AB/MF. Conforme informações colhidas junto às arquivistas, existe uma parceria entre a Organização Não-Governamenal "Internet Archive" e o Ministério da Fazenda. Até o momento, publicações do século XIX e da primeira metade do XX estão disponíveis em: <memoria.org.br> e <https://archive.org>. Acesso em: 29 dez. 2015.
} 
No primeiro caso, foi constante a frequência na Biblioteca Florestan Fernandes, da Faculdade de Filosofia, Letras e Ciências Humanas (FFLCH) e na Biblioteca da Faculdade de Economia e Administração (FEA) da Universidade de São Paulo. Em ambas, foi possível localizar anuários estatísticos de órgãos e autarquias públicas, como os do Departamento Nacional do Café (DNC), e uma parcela das publicações sobre comércio internacional da Liga das Nações. Em referência aos sítios de internet, tanto de origem governamental, bem como de centros e institutos de pesquisa nacionais e internacionais, foi encontrada uma vasta quantidade de publicações digitalizadas. No sítio do Instituto Brasileiro de Geografia e Estatística $(\mathrm{IBGE})^{35}$, foi obtida a série “Anuário Estatístico do Brasil” da década de 1930, que à época ainda era publicado pelo Instituto Nacional de Estatística (INE/BR). E no endereço eletrônico do Center for Research Librairies (CRL) ${ }^{36}$, sob a denominação de Brazilian Government Documents, há um conjunto documental bastante amplo que inclui os relatórios dos presidentes provinciais (1830-1930), mensagens presidenciais (1889-1993), o Almanak Laenmmert (18441899) e os Relatórios Anuais Ministeriais (1821-1960).

\section{- Estados Unidos}

A decisão de se utilizar documentação pertencente ou situada nos Estados Unidos justifica-se pelo seu papel durante o conflito espanhol e pela influência de sua política externa durante o período de entreguerras no continente americano, sobretudo no Brasil. Além disso, os fundos documentais nos Estados Unidos possuem diversos subsídios que, embora produzidos no Brasil ou na Espanha, não estavam disponíveis em arquivos nos países de origem. O processo de pesquisa foi conduzido nos dois principais complexos do National Archives and Records Administration: sua sede em Washington, D.C., (NARA/I) e o situado em College Park, Maryland (NARA/II), e na Franklin Delano Roosevelt Presidential Library (FDR/PL), localizado em Hyde Park, no estado de Nova York.

No NARA/I foram coletados documentos referentes aos serviços militares e de inteligência da Marinha sobre as ações dos militares sublevados no continente americano. Em College Park (NARA/II) se armazena a maior parte da produção documental dos Estados Unidos durante o século XX. Assim, assentamos a nossa procura no corpus produzido pelo Departamento de Estado e do Office of Strategic Services (OSS), do qual privilegiamos o que

\footnotetext{
35 <biblioteca.ibge.gov.br>. Acesso em: 29 dez. 2015.

36 <www.crl.edu/brazil . Acesso em: 29 dez. 2015.
} 
foi produzido internamente a respeito da Guerra Civil Espanhola, das missões diplomáticas existentes no Estado espanhol e no Brasil e das informações coletadas pelos serviços de inteligência. E em Hyde Park, antiga casa de campo de Franklin D. Roosevelt e atual arquivo e biblioteca, foi possível encontrar correspondências, discursos e memorandos do próprio presidente e de membros do alto-escalão de seu governo, como o Secretário de Estado, Cordell Hull.

No mesmo diapasão que a documentação brasileira, as publicações impressas percorreram o caminho das bibliotecas, localizadas nos Estados Unidos, e de sítios de internet. Em relação às bibliotecas, foi visitada a Library of Congress, em Washington D.C., a Public Library of New York e as pertencentes à University of Maryland. A utilização de sítios de internet para publicações, foi fundamental para percorrer as obras governamentais às quais não houve tempo hábil, como por exemplo, o Foreign relations of the United States (FRUS) ${ }^{37}$ que foram digitalizados pela University of Wisconsin em parceria com outras universidades dos Estados unidos.

\section{- Espanha}

No território espanhol, três centros documentais se tornaram a espinha vertebral das pesquisas sobre a Guerra Civil Espanhola: o Archivo del Ministerio de Asuntos Exteriores (AMAE), o Archivo General de la Admistración (AGA) e o Archivo General de la Guerra Civil (AGGC).

No AMAE, em Madri, está localizada a maior parte do acervo sobre a política externa espanhola, com uma documentação que remete ao governo republicano e à Ditadura do General Francisco Franco. A maior parcela dos papeles dos militares sublevados e das ações realizadas no exterior, no decorrer da Guerra Civil, se encontra em Alcalá de Henares (AGA). Nesse arquivo foi encontrada relevante documentação da ação dos representantes dos amotinados no exterior. As caixas encontradas revelaram que além de documentação referente ao dia-a-dia e à prestação de contas, também se incluía uma farta papelada (conhecimentos de embarque e correspondências com órgãos governamentais brasileiros) sobre a doação e venda de sacas de café do governo varguista aos militares sublevados. E, finalmente, no AGGC, em Salamanca,

\footnotetext{
$37<$ https://uwdc.library.wisc.edu/collections/FRUS/>. Acesso em: 29 dez. 2015.
} 
foram localizadas publicações impressas de difícil acesso, como é o caso de relatórios comerciais provisórios produzidos pelo governo republicano durante o conflito. ${ }^{38}$

Do encontro entre a produção historiográfica e a documentação localizada, tantos nos momentos preliminares e no decorrer da elaboração da pesquisa, surgiram os objetivos e problemáticas deste trabalho. Como escopo central, iremos desenvolver as relações entre o governo brasileiro e a Guerra Civil Espanhola, com um recorte temporal concentrado nos anos de ocorrência do conflito, ou seja, entre 1936 e 1939. Decidimos estabelecer como ponto de contato do Brasil, em suas esferas burocráticas, com a Guerra Civil e não de forma estancada junto ao governo republicano ou aos rebelados de julho de 1936 pela própria dinâmica de seu desenvolvimento.

Ao observarmos o Gráfico 1 podemos perceber que, entre 1929 e 1936, houve uma acentuada queda no volume de importações e exportações entre Brasil e Espanha. Uma trajetória que pode ser vista como "normal" dada a diminuição do fluxo comercial planetário após a crise de 1929. E, apesar do diminuto fluxo comercial entre as duas partes, entre 1929 e 1932 havia superávit a favor do Brasil, com uma inversão desse cenário entre 1933 e 1936.

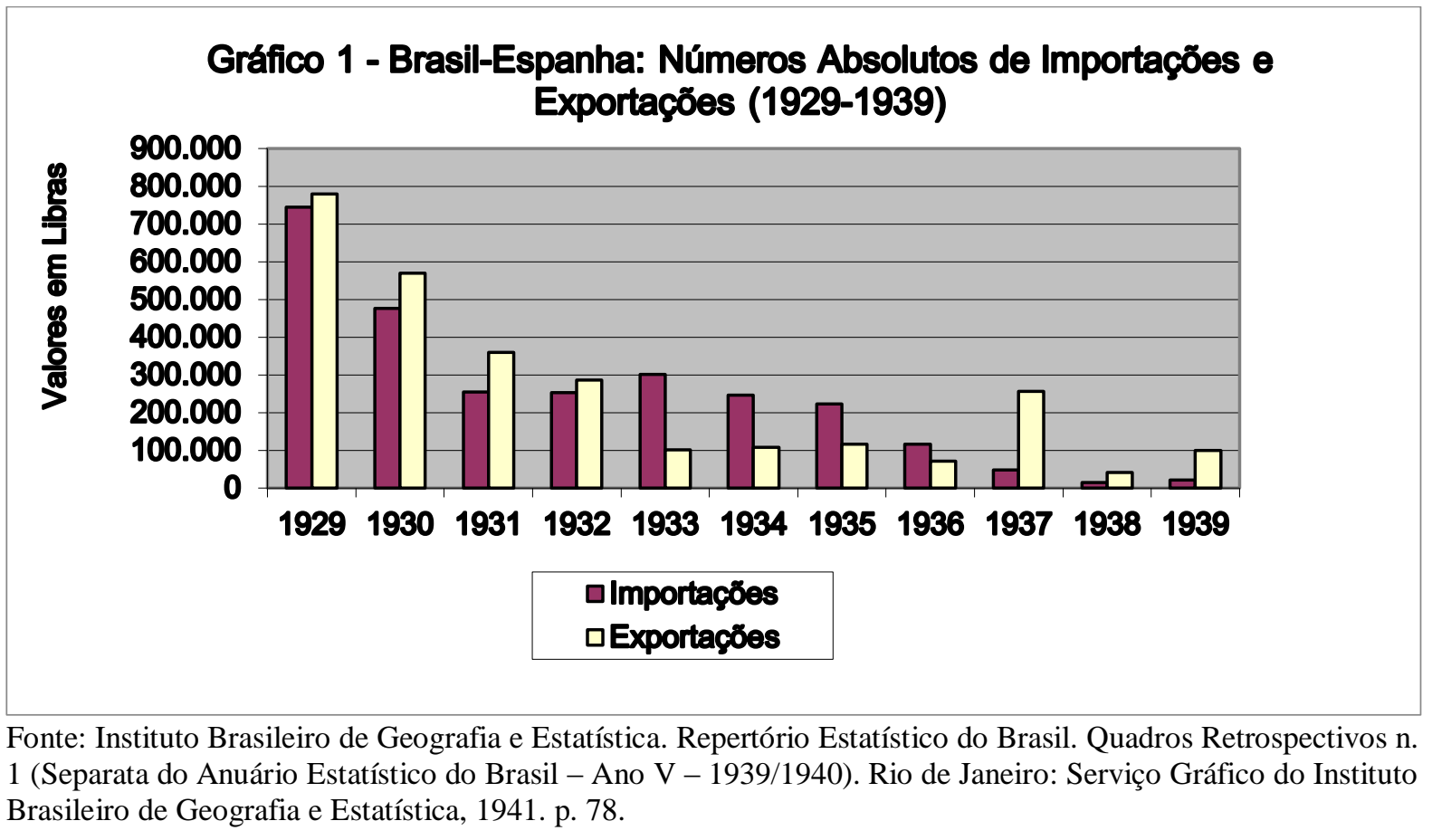

\footnotetext{
${ }^{38}$ ESPAÑA. Dirección General de Aduanas. op. cit., 1938; ESPAÑA. Dirección General de Aduanas. Sección de Estadística. op. cit., 1936.
} 
O que nos chamou atenção, inicialmente, foi o pico de exportações existente em 1937, já no decorrer de 1937 e o leve crescimento em 1938 e 1939. Principalmente em relação à 1939, justifica-se pela retomada dos contatos comerciais a partir de abril daquele ano com o fim do conflito intestino espanhol. O pico de 1937 foi alcançado, principalmente pelo envio de carne brasileira ao governo republicano. E, ainda que o processo de exportações para o governo de Madri tenha suma importância para a compreensão dos fluxos comerciais entre o Brasil e a Guerra Civil Espanhola, decidimos nos concentrar nos contatos com os sublevados.

Com o tema central da tese baseado nas relações entre o Brasil e os sublevados nos territórios espanhol e brasileiro, tomamos os seguintes objetivos a serem abordados no corpo deste trabalho:

a) Abordar as possibilidades da concretude dos embarques realizados pelo governo Vargas, em 1936, e como o percurso via Portugal foi o meio para o envio de café e açúcar;

b) Analisar e apontar as diferenciações entre os diversos embarques de café realizados em 1937 e 1938 (ao governo republicano, doações por meio da Cruz Vermelha e os embarques secretos em fins de 1937) e com isso delimitar que houve um deliberado apoio aos franquistas por parte do governo brasileiro;

c) Analisar a relação entre o governo brasileiro e as representações dos sublevados no Brasil, com o apoio destes últimos em eventos anticomunistas.

Como a Guerra Civil Espanhola teve uma duração de pouco menos que três anos, decidimos organizar a apresentação do trabalho, em três capítulos. Cada um deles objetiva analisar o espaço de um ano. No entanto, esta divisão, em alguns momentos do trabalho não foi totalmente respeitada, porque se fazia necessário retomar períodos anteriores.

No primeiro capítulo apresentamos, inicialmente, o cenário espanhol no período anterior à Guerra Civil, ou seja, do período de criação da Segunda República às vésperas do início da sublevação, em julho de 1936. Com esse cenário inicial no qual apresentamos a ascensão das forças conservadoras e as limitações do projeto republicano, o segundo item concentra-se na formação das estruturas proto-estatais e da própria formação do Gobierno de Burgos, em 1938. No terceiro item veremos a dinâmica interna de como os militares lidaram com as questões materiais conforme avançavam no controle do território espanhol. E, finalmente, no último item, apresentamos um fio condutor para o segundo capítulo. Esse quarto item, expõe o percurso adotado por certos indivíduos para a composição das representações sublevadas em 
território brasileiro, que foi estabelecido por meio de funcionários e diplomatas dos órgãos espanhóis situados no Brasil.

Em um segundo movimento, nos concentramos nas formas iniciais de contato do governo brasileiro varguista com a Guerra Civil Espanhola. Destarte, o segundo capítulo aponta, inicialmente, a trajetória das tênues relações entre o Brasil e o Estado espanhol, com um caminho que tem origem antes mesmo do início da década de 1930. Em seguida, apresentamos as possibilidades acerca do "famigerado" embarque de café por ordem de Vargas após as primeiras semanas de conflito, com as possibilidades que os dados econômicos possam contribuir para o debate desta questão e o caminho realizado por meio de Portugal. Em terceiro lugar, vamos atentar sobre os efeitos da Guerra Civil nas Américas, as tentativas de influência norte-americana para um posicionamento continental e o comportamento brasileiro diante de seus pares, principalmente no decorrer das conferências interamericanas.

Em nosso terceiro capítulo, nos concentramos no aprofundamento das relações entre o governo brasileiro e as organizações vinculadas ao franquismo que se se instituíam paulatinamente na Espanha. No interior dessa terceira parte da pesquisa, iniciamos com a concentração de estratégias de aproximação e de reconhecimento que os "nacionalistas" gestavam junto ao governo brasileiro e a percepção que os sublevados possuíam sobre o Estado Novo. Ademais, abordaremos a interferência que o putsch integralista de 1938, provocou junto aos representantes do pronunciamiento de 17 de julho de 1936. E, finalmente, os dois últimos itens deste capítulo, embora expostos de forma fracionada, fazem parte de um mesmo ponto de análise: um aprofundamento na aproximação entre as representações nacionalistas no Brasil e órgãos do governo brasileiro. Esse processo aconteceu por meio de embarques secretos e deliberadamente desviados de seus destinos finais para fornecer café ao território franquista; e, pela solicitação de apoio à Junta Nacionalista no Brasil para o fornecimento de material para uma exposição anticomunista em 1938, com um acento final sobre o processo de reconhecimento do Estado franquista pelo Brasil.

Em nossas considerações finais, apresentamos um cenário de transição e um amplo quadro acerca das condições das relações entre o Brasil e a Espanha, já sob o completo jugo franquista. E, como as doações continuaram a ocorrer, mesmo com o reconhecimento do novo regime por Vargas e o paulatino reestabelecimento de uma certa normalidade das relações bilaterais entre os dois países, ainda que começasse a pesar a influência norte-americana para o isolamento internacional do Estado franquista. 
Os anexos apresentam uma parcela dos documentos e fontes abordadas no decorrer desta pesquisa. Durante todo o processo de pesquisa, iniciado ainda em 2004, mais de cinco mil páginas de documentos foram coletadas, entretanto, preferimos expor aqueles que fizeram parte dos itens centrais deste trabalho, principalmente no decorrer do primeiro e do terceiro capítulo. 


\section{A Guerra Civil Espanhola: dos antecedentes à composição sublevada}

\subsection{Segunda República Espanhola: reformismo, conservadorismo e guerra}

O Estado espanhol sofreu, no decorrer dos séculos XVIII e XIX, um lento processo que o levou ao patamar mais baixo do capitalismo europeu, com um território amplamente agrícola e parcos focos industrializados, como era o caso da Catalunya e Euskadi. Essa condição, capitaneada pela monarquia e/ou pelos pronunciamientos ${ }^{39}$ militares no decorrer do século XIX e em sua penúltima ocorrência em 1923, pelo General Miguel Primo de Rivera, esteve relacionada à manutenção de uma aristocracia tradicionalista aliada à Igreja Católica no controle da Espanha e de seus espaços coloniais. ${ }^{40}$ No interior desse longo espaço temporal, também houve a manutenção de uma débil classe média, operários e camponeses em condições de extrema penúria. A afirmação de Marx sobre as condições germânicas de produção, que eram "atormentadas não só pelos vivos, como também pelos mortos", ${ }^{41}$ também pode ser estabelecida, como uma abstração razoável, para a longa e decadente trajetória espanhola.

A tentativa da monarquia e dos próprios militares para retomar para si as rédeas da combalida sociedade espanhola, se sintetizou no pronunciamiento do General Miguel Primo de Rivera em 1923. Após uma década envolta em greves e movimentos operários de grande envergadura que rondaram o Estado espanhol, o princípio da década de 1920 assistiu ao surgimento do Partido Comunista Español (PCE), ao fortalecimento dos sindicatos e o próprio descrédito do Exército com as derrotas nas possessões coloniais no norte africano. Assim, a ascensão de Primo de Rivera surgiu como uma tentativa autocrática do Exército, embora

\footnotetext{
${ }^{39}$ Com origem nas Guerras Napoleônicas, o exército espanhol tornou-se um dos principais recônditos das classes dominantes espanholas. De acordo com Pierre Broué: “(...) o Exército é uma força social que busca o apoio de uma classe dominante ferida de morte, e sua coluna vertebral, a casta de oficiais, aferra-se mais do que a todos os seus outros privilégios, ao de se 'pronunciar', isto é, de apossar-se, em proveito próprio, das prebendas do Estado através do golpe de Estado military cuja tradução exata em epsanhol é o pronunciamiento ( = rebelião, revolta)." BROUÉ, Pierre. A Revolução Espanhola, 1931-1939. São Paulo: Perspectiva, 1992, p. 21.

${ }^{40}$ Como apresentado em nossas considerações iniciais, o atraso do capitalismo espanhol atravessa a vasta historiografia existente. No entanto, no conjunto total de obras, destacam-se: "La República en España. Der Volkstaat. 01 de marzo de 1873”. In: MARX, Karl; ENGELS, F. Escritos sobre España. Extractos de 1854. Madrid: Editorial Trotta/Fundación de Investigaciones Marxistas, 1992; NADAL, Jordi. El fracas de la revolución industrial en España, 1814-1913. Barcelona: Ariel, 1975; TROTSKY, Leon. Escritos sobre España. Paris: Ruedo Ibérico, 1971; VILAR, Pierre. A História da Espanha (1936-1939). Rio de Janeiro: Paz e Terra, 1992.

41 "Prefácio da Primeira Edição" In: MARX, Karl. O Capital. Crítica da Economia Política. Livro Primeiro. O Processo de Produção do Capital. Tomo 1. São Paulo: Nova Cultural, 1996, p. 131.
} 
avalizada pelo próprio rei Alfonso XIII (1886-1931), em impedir tanto o avanço dos movimentos operários, como da classe média. ${ }^{42}$

Os atos iniciais da Ditadura, se sustentaram em um aprofundamento da repressão, com outorga de uma lei marcial em casos de distúrbios que poderiam ser causados por sindicatos, movimentos de esquerda e a população em geral. Em outubro de 1923, um mês após a criação do regime ditatorial, se realizou a substituição de elementos civis por militares na maioria dos cargos administrativos, como foi o caso dos conselhos municipais, que eram vistos como um dos focos de intrusão das esquerdas no âmbito estatal.

O processo autocrático de poder teve continuidade na instituição de um regime unipartidário por meio da criação da Unión Patriótica (UP). Mesmo sem ter sido concebido como um partido fascista, foi fundado em 1925 e tornou-se um dos bastiões iniciais da introdução do fascismo italiano em território espanhol, por meio de um de seus principais líderes civis, Angel Herrera. ${ }^{43}$

Em relação ao seu programa econômico, foram apresentadas propostas extremamente restritas e que se circunscreviam à obras públicas e à manutenção da tradicional política protecionista aduaneira espanhola, em vigência desde o século XIX.${ }^{44}$ Destarte, se por um lado os problemas de hegemonia política conservadora tentavam ser solucionados, por outro, a Ditadura de Primo de Rivera agiu no sentido de impedir a autonomia do restrito empresariado em território espanhol. Mesmo com a penetração do capital espanhol em um fluxo bastante elevado, até a crise da Ditadura em 1930, a sua concentração ficou nas mãos do Estado. O alto dirigismo estatal fez com que houvesse um salto de $40 \%$ na participação industrial no interior do Estado espanhol, fenômeno que só alcançaria índice semelhante no decorrer das décadas de 1960 e $1970 .{ }^{45}$

No decorrer dos 7 anos de Primo de Rivera foram criados diversos dispositivos burocráticos, que tinham como objetivo o constante controle econômico e uma retomada dos saldos positivos da balança comercial espanhola logo após o fim da Grande Guerra. Um dos

\footnotetext{
${ }^{42}$ Cf. TUSSEL, Javier. Radiografia de un golpe de Estado. El ascenso al poder del General Primo de Rivera. Madrid: Alianza Editorial, 1987. Tussel apresenta em uma das poucas obras que se aprofundam na ascensão de Primo de Rivera, uma profunda análise do golpe em 1923 e as relações entre os militares e civis até 1930.

${ }^{43}$ Em nossa dissertação de mestrado apresentamos, sob a orientação do Prof. Dr. Antonio Rago Filho, no decorrer do primeiro capítulo, o curso de chegada das ideias fascistas no estado espanhol: Cf. CAMARGO, Fernando Furquim de. O Ideário Falangista de José Antonio Primo de Rivera (1931-1936). São Paulo, 2002. Dissertação (Mestrado em História) - Programa de Estudos Pós-Graduados em História, Pontifícia Universidade Católica de São Paulo.

${ }^{44}$ Cf. SANCHEZ-ALBORNOZ, Nicolás (comp.) La modernización de España, 1830-1930. Madrid: Alianza Editorial, 1987.

${ }^{45}$ PAYNE, Stanley G. Franco y José Antonio: El Extraño Caso del Fascismo Español. Barcelona: Planeta, 1997, p. 101.
} 
principais pontos da tentativa de estimular a economia externa espanhola e promover o seu desenvolvimento interno foi a criação, ainda em 1924, do Conselho Nacional de Economia. O mecanismo intervencionista que pretendia conciliar os interesses liberais com os interesses de um maior ingresso de divisas, terminou por aprofundar o modelo protecionista espanhol. Um dos casos emblemáticos foi a criação da Compañia Arrendataria del Monopolio del Petróleo S.A. (CAMPSA), que passou a deter o monopólio sobre a distribuição do petróleo e seus derivados.

As ações no campo do transporte também alcançaram patamares bastante elevados na tentativa de expansão produtiva e comercial. Para o incremento da malha ferroviária e das estradas de rodagem, que havia sido negligenciado nas décadas anteriores, houve um crescimento de $50 \%$ no conjunto dos impostos cobrados, que seriam amenizados com os aumentos da distribuição interna de mercadorias e do fluxo externo. Contudo, a relação entre a elevação de impostos e o incremento da malha distributiva redundou em crise, pois, mesmo com uma maior arrecadação, devido aos baixos salários e diminuto poder aquisitivo dos trabalhadores, não foi o suficiente para que as contas saíssem de sua condição de desequilíbrio. E no caso externo, certas condições de seu atraso não foram superadas. ${ }^{46}$ Assim, o problema crucial do desequilíbrio espanhol residia na incompatibilidade entre a tentativa de uma política progressiva e de expansão externa, com a condição de restrição do seu mercado interno. ${ }^{47}$

Ao final da década de 1920, houve tentativas derradeiras de se manter a tradicional concentração de poder no Estado espanhol nas mãos da aristocracia e da monarquia. No entanto, com suas condições de sociabilidade agravada pela deterioração interna do período da Ditadura de Primo de Rivera e com os grupos que estiveram profundamente marginalizados em franca ascensão, surgiram mínimas condições de transformação. Segundo Gabriel Jackson:

(...) quando a depressão mundial abalou a Espanha, pelos fins de 1929, o rei despediu Primo de Rivera e esforçou-se em vão para arranjar um ditador que o substituísse. Em 17 de agosto de 1930, numerosas personalidades políticas assinaram, em San Sebastián, um pacto político que já anuncia, de certo modo, a Segunda República. Nesse documento concorda-se no estabelecimento do regime republicano, se necessário pela força, garante-se a liberdade religiosa, se defende a realização de eleições para Cortes Constituintes e a permissão

46 VIÑAS, Angel et al. Política Comercial Exterior en España (1931-1975). Madrid: Banco de España, tomo 1, 1979, p. 33.

${ }^{47}$ Em sua obra mais recente, Barry Eichengreen promove um aprofundamento das análises dos países envolvidos em crises financeiras. Nesse sentido, os ajustes voltados para estimular o desenvolvimento do capitalismo espanhol na década de 1920 e sua intersecção com os efeitos limitadores da crise de 1929 tornam-se relevantes para a compreensão das diversas especificidades existentes. Cf. EICHENGREEN, Barry. Hall of Mirrors. The Great Depression, The Great Recession and the uses - and misuses - of History. New York: Oxford University Press, 2015. 
das regiões, que o desejassem, de organizarem estatutos de autonomia e de os submeterem à aprovação das Cortes. ${ }^{48}$

Em uma franca tentativa de se obter um protagonismo até então inexistente, o Pacto de San Sebastián envolveu uma amplitude de vieses políticos, com católicos conservadores (Niceto Alcalá-Zamora e Miguel Maura), republicanos de direita (Alejandro Lerroux), republicanos considerados progressistas (Manuel Azaña e Casares Quiroga), socialistas (Idalecio Prieto) e mesmo forças regionais que lutavam por projetos autonômicos, como foi o caso do liberal catalão Nicolau d'Oliver. Nota-se que no conjunto dos participantes da reunião em San Sebastián não houve a participação dos movimentos operários e camponeses, com exceção da Unión General de Trabajadores (UGT), que de forma indireta foi representado pelo dirigente do Partido Socialista Obrero Español (PSOE), Idalecio Prieto.

As eleições municipais, realizadas em 12 de abril de 1931, tornaram-se o momento de ascensão dos signatários do Pacto. O pleito, convocado pela própria monarquia e por meio de caciques locais e regionais que apoiassem os candidatos monarquistas, objetivava a tentativa de continuidade de um regime que já se encontrava moribundo pelo acirramento das contradições sociais no interior do Estado espanhol. Dois dias após a votação, com a vitória dos candidatos de oposição, chegou ao fim a monarquia espanhola e o reinado de Alfonso XIII, que desde 1923 havia se mantido no poder por intermédio de um Diretório Militar (1923-1925) e um Civil (1925-1931), ainda que controlado pelos militares. O regime controlado pelo rei, pelo General Primo de Rivera (1923-1930) ${ }^{49}$ e em sua reta final, entre janeiro de 1930 e abril de 1931, pelo General Dámaso Berenguer y Fusté, terminou com Berenguer sendo processado, o rei exilado e a criação da Segunda República Espanhola.

Após dois dias, a Segunda República emergiu em um governo provisório e sob a presidência de Niceto Alcalá-Zamora, com a composição do novo regime com a maioria dos membros oriundos do Pacto de San Sebastián. ${ }^{50}$ Em consonância com o Governo Provisório, elegeu-se, em junho de 1931, Cortes Constituintes para a elaboração de uma carta constitucional que rompesse com a estrutura tradicional do Estado espanhol. No entanto, a própria variedade de posicionamentos políticos trouxe à tona, de forma célere, diversas contradições existentes no interior do Pacto e da própria sociedade espanhola.

\footnotetext{
${ }^{48}$ JACSKON, Gabriel. La República española y la Guerra Civil. 2a Ed. Barcelona: Grijalbo, 1976, p.28.

49 O General Miguel Primo de Rivera após sair da direção da Ditadura, se exilou em Paris e faleceu em 16 de março de 1930.

${ }^{50}$ O Governo Provisório da Segunda República teve, além de Niceto Alcalá-Zamora como presidente, Miguel Maura (Ministro do Interior), Nicolau d'Olwer (Ministro da Economia), Idalecio Prieto (Ministro das Finanças), Manuel Azaña (Ministro da Guerra) e Largo Caballero (Ministro do Trabalho), entre outros.
} 
As forças políticas pertencentes ao grupo monárquico e que haviam sido apeadas do poder tentaram aproveitar, desde os primeiros momentos do novo regime, a democracia da nova república parlamentarista para retomar a centralidade política perdida. $^{51}$ Os grupos privilegiados que não faziam parte da monarquia e da Ditadura Militar dos anos de 1920, como certas parcelas da oligarquia e a diminuta burguesia urbana, viam a Segunda República como um dos meios de se evitar quaisquer iniciativas revolucionárias por parte dos trabalhadores. E, uma pequena burguesia urbana contemplava a possibilidade de uma regeneração econômica do país, da qual ela poderia sair beneficiada a partir do aumento de importância dos centros urbanos em substituição ao campo.

O operariado e o campesinato encontravam-se em uma situação complexa. Os partidos de esquerda, como o PSOE, sindicatos e grupos anarquistas, encontravam-se em uma condição de fragmentação devido à multiplicidade de posicionamentos da esquerda, que, segundo Pierre Broué, se comportavam como uma hidra sem cabeça. ${ }^{52}$ No entanto, a militância dos trabalhadores rurais e urbanos viam o novo governo republicano como um instrumento para a reivindicação de seus direitos e a superação da condição de extrema miséria sob a qual eram submetidos. O julgamento de estarem em um processo revolucionário foi bastante acentuado para os trabalhadores e, baseado em ações diretas e com fortes movimentos anticlericais, devido à tradicional aliança da Igreja com a monarquia espanhola, tomaram profundos contornos nos dias seguintes ao surgimento do governo provisório republicano. De acordo com Tuñon de Lara:

Em Madrid arderam seis conventos, uma igreja e uma residência dos jesuítas. A Guarda Civil patrulhava a cavalo, mas sem intervir. (...) foram incendiados um convento e o Palácio Episcopal de Málaga. No dia seguinte, os incêndios se propagaram por Sevilha, Cádiz, Córdoba, Murcia, Alicante, Valência.... Nada aconteceu na Catalunha, nem no norte da Espanha. ${ }^{53}$

\footnotetext{
51 As estratégias de dispersões e reagrupamentos dos partidos conservadores, em suas diversas especificidades podem ser observadas nas diversas alterações partidárias entre 1931 e 1933. Ademais, nota-se também, as tentativas de enraizamento do ideário fascista presente no interior do estado espanhol desde 1925. Embora não seja objeto desta pesquisa, sugerimos a seguinte literatura sobre o tema: CUEVAS, Pedro C. González. Historia de las derechas españolas: De la Ilustración a nuestros días. Madrid: Biblioteca Nueva, 2000; PASTOR, Manuel. Los Orígenes del fascismo en España. Madrid: Tucar, s/d; PAYNE, Stanley G. Franco y Jose Antonio: El Extraño Caso del Fascismo Ibérico. Barcelona: Planeta, 1997; PAYNE, Stanley G. Falange: Historia del fascismo español. Paris: Ruedo Iberico, 1970; PRESTON, Paul. The Coming Of The Civil War: Reform, Reaction and Revolution in The Second Republic. London: Routledge, 1994.

52 BROUÉ, Pierre. A Revolução Espanhola (1931-1939). São Paulo: Perspectiva, 1992, p. 25-33.

53 TUÑON DE LARA, Manuel. La II República. Madrid: Siglo Veintiuno, 1976, p. 68.
} 
Enquanto os trabalhadores se organizavam para o combate às velhas forças conservadoras, o governo republicano dirigido por Alcalá-Zamora, católico conservador, entrou em convulsão interna devido as propostas da nova carta constitucional espanhola. Pois, além da própria instituição de um governo republicano, dos estatutos autonômicos e das próprias liberdades individuais, a questão religiosa tornou-se um dos motivos da saída dos membros mais conservadores do governo provisório. De acordo com a Constituição de 1931, o artigo 26 afirmava que:

O Estado, as regiões, as províncias e os Municípios não manterão, favorecerão, nem auxiliarão econômicas às Igrejas, Associações e Instituições religiosas. (...). Ficam dissolvidas aquelas Ordens religiosas que estatutariamente imponham, além dos três votos canônicos, outro especial de obediência a autoridade distinta da legítima do Estado. Seus bens serão nacionalizados e dirigidos a fins benéficos e docentes. ${ }^{54}$

Ainda que em um momento anterior à da aprovação da Constituição, as discussões nas Cortes e a relação com um poder executivo que se comportava de forma dividida, provocaram a saída do próprio Alcalá-Zamora, em 14 outubro de 1931. Com a ascensão do então Ministro do Interior, Manuel Azaña, as reformas pela instituição de leis agrárias, de autonomia regional e do próprio laicismo do novo regime republicano tomaram fôlego e foram incluídas no novo texto constitucional. No entanto, em eleição realizada no dia seguinte à proclamação da nova Constituição, as próprias Cortes reconduziram Alcalá-Zamora à presidência da República e Azaña como Presidente de Governo.

A transição do Governo Provisório, ou Governo da República, para a plenitude de um regime presidencialista não alterou as condições de tensões internas existentes no Estado espanhol. Ainda que a Acción Republicana (AR), fundada pelo próprio Manuel Azaña estivesse em seu discurso alinhada às propostas de esquerda, a coexistência no poder junto ao Partido Republicano Progresista (PRR), de Alcalá-Zamora, tornou o próprio poder executivo um palco das contendas existentes na Espanha. Ou seja, um governo que se expunha como de esquerda ou de forma progressista, mas que nos dois anos seguintes, cunhado como o biênio republicano, manteve a lógica repressiva, principalmente junto aos camponeses, que em grande parcela era adepta da ação direta e que não estava no PSOE, partido de esquerda que compunha a base republicana. Sobre a situação, Calleja afirma que:

\footnotetext{
54 CONGRESO DE LOS DIPUTADOS. Constitución de la República Española (9 de deciembre de 1931).
} Disponível em: 〈http://www.congreso.es/docu/constituciones/1931/1931_cd.pdf>. Acesso em: 19 dez. 2015. 
O papel do Exército como poder arbitral (...) não seria durante a República muito diferente do Reischwer durante a República de Weimar. Sua ruptura com o regime monárquico (...) não se rompeu com a proclamação da República, mas que se manteve como fator residual até a ação falha de Sanjurjo em Sevilha. ${ }^{55}$

A situação de similaridade dos primeiros anos de governo republicano com as circunstâncias de Weimar apresentou-se com a manutenção incólume da estrutura militar espanhola do regime anterior. Ou seja, manteve-se um oficialato de origem monárquica que enveredou pelo controle do governo republicano junto aos grupos que não compactuavam com a proposta reformista que se implementou com a Segunda República. Em 1932, com as limitações impostas pela Segunda República, as ações dos grupos anarquistas tomaram maior vulto, devido à manutenção de condições societárias que não se alteraram com as propostas apresentadas pela nova Constituição e pelo próprio governo.

Na própria virada de 1931 para 1932 ocorreu uma forte repressão da Guarda Civil na cidade de Castilblanco, situada na Extremadura. Após uma manifestação de operários ter sido considerada ilegal, uma escaramuça entre trabalhadores e soldados terminou com a morte desses últimos. Quase de forma concomitante, outra ação da Guarda Civil, em 5 de janeiro de 1932, acarretou na morte de 11 de pessoas e mais uma trintena de feridos no povoado de Arnedo, na La Rioja. Em decorrência do massacre houve a destituição do diretor-geral da Guarda Civil, o General José Sanjurjo. Assim, logo em princípios do primeiro ano de existência da República, o governo angariou a oposição do Exército, pela destituição do General, e da população que clamava por maiores punições aos culpados pelos acontecidos em Arnedo e Castilblanco.

A reação do próprio Sanjurjo aconteceu em 10 de agosto de 1932, com uma tentativa de golpe conhecida como "Sanjurjada". Com um pronunciamento realizado em Sevilha, houve a primeira tentativa de derrubada do governo por parte do Exército. Embora tenha tido um caráter restrito, o governo de Manuel Azaña, após a prisão do General direcionou-se à uma aproximação com os trabalhadores e com os interesses regionais com tentativas de aceleração da reforma agrária e da instituição do Estatuto da Catalunha. Devido ao grande índice de desemprego, começou a ocorrer uma forte pressão por parte das principais centrais sindicais: a

\footnotetext{
${ }^{55}$ CALLEJA, Eduardo G. La violencia política y la crisis de la democracia republican (1931-1936). Hispania Nova: Revista de Historia Contemporánea, número 1, 1998-2000. Disponível em: <http://hispanianova.rediris.es/general/articulo/003/art003.htm〉. Acesso em: 19 dez. 2015.
} 
anarquista Confederación Nacional del Trabajo (CNT) e a socialista Unión General de los Trabajadores (UGT).

No entanto, a perda do frágil apoio dos anarquistas ao governo republicano e um profundo enfraquecimento de Manuel Azaña ocorreu com os acontecidos de "Casas Viejas". Em 10 de janeiro de 1933, uma ocupação anarquista da CNT no vilarejo de Casas Viejas, na Andaluzia, destituiu o alcaide local e tentou tomar o quartel da Guarda Civil. A repressão do governo republicano, por meio da própria Guarda Civil e da Guarda de Assalto republicana, provocou a morte de inúmeros anarquistas.

Além da perda de apoio das esquerdas por parte do governo, o ano de 1933 concentrou a organização de partidos voltados à lógica fascista. Acelerou-se o crescimento e fortalecimento da Confederación Española de Derechas Autonómas (CEDA), dirigido pelo antigo colaborador da Ditadura Militar de Primo de Rivera, José María Gil-Robles; e, da Falange Española Tradicionalista, comandada por José Antonio Primo de Rivera, filho do General Primo de Rivera.

A relação entre o enfraquecimento das esquerdas e o fortalecimento das direitas espanholas nos primeiros meses de 1933 foi sentida nas eleições municipais de abril daquele ano. Com a perda do apoio anarquista, a composição republicana perdeu uma grande parcela dos municípios o que ocasionou o retorno dos conservadores aos cargos municipais. Ademais, no pleito de novembro para as Cortes, a CEDA obteve 115 cadeiras, os socialistas conseguiram 55 e o grupo governista-azañista ocupou somente 5 das vagas parlamentares. Os governamentais efeitos deletérios do biênio republicano também atingiram grupos que obtiveram conquistas na nova carta constitucional de 1931. Esse fenômeno pode ser atribuído, pela própria lógica impetrada desde 1931, por um processo de transformação imposto de forma hierarquizada e que impedia um caminho transformador (ou revolucionário) que emergisse desde as bases da sociedade espanhola, pois, o enraizado conservadorismo e a influência da Igreja Católica não haviam sido extirpados.

De forma concomitante à vitória do viés mais conservador dos republicanos, dos incipientes partidos hispano-fascistas e de antigos monarquistas, a guinada do novo governo republicano nos dois anos em que esteve no poder (1933 a 1935) provocou no Estado espanhol um retorno a condições políticas similares ao período anterior a 1931. Enquanto houve a manutenção de Niceto Alcalá-Zamora na presidência republicana, o biênio conservador alçou ao poder Alejandro Lerroux, como presidente de governo, que estancou os avanços alcançados pelos primeiros dois anos republicanos. De acordo com Enric Mompó: 
(...) a direita conseguia a vitória nas eleições. Ao não alcançar a maioria absoluta e como consequência da nova correlação de forças, a tarefa de formar o governo recaiu ao centro (Alejandro Lerroux). A direita (a CEDA e os monárquicos) apoiou ao novo governo à espera de que logo chegaria a sua oportunidade. ${ }^{56}$

A concentração de conservadores à frente da Segunda República anistiou os militares envolvidos na Sanjurjada, imobilizou os processos de reforma agrária, reduziu os salários agrícolas e a presidência dos Jurados Mistos, que negociava as relações entre patrões e empregados de forma paritária, concentrou-se nas classes patronais. E, no movimento de aliança entre a CEDA e republicanos moderados, dinamizou-se a entrega do poder aos grupos de direita e de talhe tradicionalista, sobretudo os oriundos das regiões agrárias. Ademais, os moderados, que estiveram ao lado das forças mais progressistas do governo republicano, acabaram por compor o governo conservador.

O movimento reativo dos trabalhadores relacionado com a vitória conservadora de 1933 apresentou-se por meio de convocações de greves gerais, tanto pelo PSOE e pela UGT, bem como pelos anarquistas. Enquanto que os primeiros promoveram uma série de levantes contra o governo de Madri, o anarquismo esteve à frente de ações diretas revolucionárias, como nas greves de mineiros e na criação da Comuna das Astúrias, em outubro de 1934. Embora as tentativas de movimentações de trabalhadores terem alcançado diversas regiões do Estado espanhol, se destacaram as ações na província de Oviedo. Pois, se em outras regiões o limite do movimento operário eram greves, a emergência de um sistema comunal e autônomo transformou-se, como afirma Enric Mompó, ${ }^{57}$ no ponto em que a mobilização dos trabalhadores alcançaria seu ponto mais alto, com um caráter insurrecional e autonômico.

Com o fim da curta revolução asturiana e o fracasso das greves nos grandes centros espanhóis, o governo republicano-conservador deu continuidade ao seu processo de desmantelamento das conquistas obtidas entre os anos de 1931 e 1933. Dessa forma, o ano de 1935 iniciou-se com uma hegemonia das direitas, o que não impediu as fraturas na condução do governo.

Embora o gabinete fosse composto de diversos vieses de direita, o controle do legislativo e a grande influência da CEDA no executivo impediam quaisquer propostas de alteração da composição social e econômica espanhola. Esse caráter se destacou nas tímidas

\footnotetext{
${ }^{56}$ MOMPÓ, Enric. La Revolución sin cabeza. Barcelona: mimeo, 2001, p. 04.

${ }^{57}$ Idem. Octubre de 1934. Barcelona: mimeo, 2001, p. 02.
} 
tentativas de alteração das leis de terras e na disseminação, ou ao menos a manutenção, de escolas públicas primárias nos pequenos povoados.

Em relação a situação das terras e de sua produtividade, o próprio Ministro da Agricultura, Manuel Giménez Fernández, tentou criar leis para o fomento de pequenas propriedades familiares e o Ministro de Instrução Pública, Filiberto Villalobos, teve sua proposta de ampliação de escolas e subsídios para moradia de professores nos próprios povoados sumariamente negada. Ao primeiro, lhe foi imposto cláusulas que impediriam o sucesso da empreitada tornando a proposta inútil; o segundo, além de ser acusado de promover a laicidade na educação, foi demitido ao final de 1934.

De forma incisiva, Gabriel Jackson ao analisar a situação afirma que apesar de certos matizes, em 1935, o governo republicano era descaradamente reacionário. A reforma agrária foi peremptoriamente negada e o orçamento da educação pública foi paulatina e miseravelmente reduzido. Além disso, devolveu as propriedades aos jesuítas, favoreceu o setor antirrepublicano do Exército, e não houve a aprovação de impostos que de alguma maneira pudessem prejudicar os ricos. Sua impopularidade e sua carência de programa o forçou a depender constantemente de poderes de exceção. ${ }^{58}$

Em um cenário mais amplo, a Revolução das Astúrias no ano anterior, tornou-se um elemento balizador da política interna espanhola. Em torno das direitas, o fato de um levante de trabalhadores ter alcançado tamanha amplitude e não ter sido punido de forma profunda, ou seja, com pena de morte, trazia maiores desconfianças no interior da própria administração. E, alimentou o surgimento e/ou fortalecimento de partidos mais associados aos pressupostos do fascismo europeu do que dos tradicionais grupos oligárquicos. Nesse caso, o fenômeno mais contundente foi o crescimento da Falange criada pelo filho do General Primo de Rivera, José Antonio. ${ }^{59}$

Nesse ínterim, as esquerdas também passaram por uma reorganização. A reestruturação do movimento operário, seja por meio dos sindicatos ou partidos tiveram um pilar interno e outro externo. Internamente, o PSOE e seu braço sindical, a UGT, iniciaram discussões a

\footnotetext{
${ }^{58}$ JACSKON, Gabriel. La República española y la Guerra Civil. 2a. Ed. Barcelona: Grijalbo, 1976, pp. 165.

${ }^{59}$ Criada em outubro de 1933 por José Antonio Primo de Rivera, a Falange Española (FE) possuía uma proposta antiliberal e antidustrialista que absorveu diversas influências do fascismo italiano. Em 1934 fundiu-se com outro grupo de orientação fascista, as Juntas de Ofensiva Nacional-Sindicalista (JONS). Nominada inicialmente como Falange Española de las Juntas de Ofensiva Nacional-Sindicalista (FET de las JONS), no decorrer da Guerra Civil e após a morte de José Antonio (1936) tornou-se o principal braço político de apoio aos militares sublevados e ao fim do conflito, o único partido permitido no decorrer da Ditadura franquista. Cf. CAMARGO, Fernando F. De. O ideário falangista de José Antonio Primo de Rivera (1931-1939). São Paulo: Dissertação de Mestrado, PUCSP, 2002; PAYNE, Stanley G. Franco y Jose Antonio: El Extraño Caso del Fascismo Ibérico. Barcelona: Planeta, 1997.
} 
respeito dos caminhos a serem tomados após o apoio de parte majoritária do partido. A Federación Anarquista Ibérica (FAI) e a CNT tomaram maior protagonismo, pois além dos sucessos no movimento asturiano, conseguiram promover um conjunto de greves gerais em grande parte do território espanhol. E, finalmente a situação do Partido Comunista Español (PCE). Criado em 1920, e com um papel bastante restrito nos primeiros anos da Segunda República, o PCE obteve um aumento em suas fileiras, a partir de 1935, com as mudanças de diretrizes a partir das resoluções da Terceira Internacional. As resoluções estabeleciam a prioridade no combate ao fascismo em substituição ao combate à socialdemocracia.

Com o aumento do poder e pressão exercidos pelos movimentos operários e os conflitos internos do governo conservador republicano, o Presidente Alcalá Zamora dissolveu o Parlamento e convocou eleições para 16 de fevereiro de 1936.

O processo eleitoral aprofundou a bipolarização no cenário espanhol. No decorrer dos 4 anos anteriores em que predominou um biênio composto por reformistas (hegemônicos politicamente nos primeiros dois anos republicanos) e outro por conservadores, as possibilidades para um processo revolucionário situaram-se de forma reduzida e pontual. Salvo a revolução asturiana de 1934, não houve ameaça concreta aos poderes constituídos das administrações republicanas. No entanto, com o pleito que se avizinhou, solidificou-se a formação de dois blocos distintos, sendo que um deles teria maciço apoio de vertentes de esquerda e o outro de conservadores e reacionários.

A Frente Popular, ainda que formalmente constituída em janeiro de 1936, agrupou os reformistas e os diversos setores de esquerda, com uma amplitude que incluía republicanos liberais, socialistas e comunistas, que de uma forma ou de outra estavam excluídos do governo republicano desde 1933. ${ }^{60}$ De forma abrangente, o programa da Frente Popular centrava-se na plena anistia aos prisioneiros políticos das revoltas camponesas e operárias do período conservador, no retorno das políticas seculares, educacionais e regionais do biênio reformista (1931-1933) e a restauração da autonomia catalã. ${ }^{61}$

\footnotetext{
${ }^{60}$ A Frente Popular foi formada pelo PSOE, PCE, Izquierda Republica (IR), Partido Sindicalista (uma dissidência da CNT), Partido Republicano Federal (PRF), Partido Obrero de Unificación Marxista (POUM) e a UGT. Além do apoio de diversos grupos anarquistas e partidos regionais. Cf. TUÑON DE LARA, M. \& NÚÑEZ DE ARENA, M. Historia del movimento Obrero Español. Barcelona: Nova Terra, 1979; BROUÉ, Pierre. A Revolução Espanhola (1931-1939). São Paulo: Perspectiva, 1992; IBÁRRURI, Dolores et al. Guerra y Revolución em España (1936-1939). Moscú: Editorial Progreso, 3 tomos, 1967.

${ }^{61}$ JACKSON, Gabriel. "The Spanish Popular Front, 1934-7” In: Journal of Contemporary History, Vol. 5, N. 3, Popular Fronts (1970), p. 28.
} 
O bloco conservador se tornou um amálgama de candidatos da contrarrevolução, como afirma Enrique Moradiellos, ${ }^{62}$ ou seja, um disperso conjunto de candidaturas de diversas tendências conservadoras e reacionárias, com dois traços comuns: o apoio da Igreja Católica e a rejeição contra quaisquer transformações reformistas ou revolucionárias. Dessa, forma ainda que houvesse a propagação de que as candidaturas contra a Frente Popular seriam uma coalização "centrista", o predomínio da CEDA em seu interior não permitia margem a propostas que fossem minimamente transformadoras.

A vitória eleitoral da maior parte dos candidatos da Frente Popular, ainda que por uma margem estreita (não mais que 200.000 votos), deu a maioria nas Cortes ao deter 278 cadeiras, contra 124 dos conservadores/reacionários e 51 do que se convencionou chamar de centristas. ${ }^{63}$

A vitória frentista trouxe à tona possibilidade de que partidos, organizações autonomistas e sindicatos, que na trajetória espanhola estiveram marginalizados e alheios à quaisquer formas de participação política, tomassem a frente na condução do governo republicano. Ou ainda, que fossem vanguardas de um processo revolucionário. No entanto, o governo conservador, que havia ascendido em 1933, intentou no dia 17 de fevereiro, dia seguinte às eleições, articular uma intervenção militar. O líder da CEDA, José María GilRobles, e o General Francisco Bahamonde Franco propuseram a utilização das Forças Armadas ao então primeiro-ministro, Manuel Portela-Valladares, para que se evitassem "incidentes" vinculados à vitória da Frente Popular. Com a recusa do primeiro-ministro e do presidente Alcalá-Zamora em utilizar a manu militari, Franco foi questionado dos motivos pelos quais o próprio Exército não tomava a dianteira. De acordo com o próprio general, o Exército não possuía a unidade moral necessária para tal empreitada. ${ }^{64}$

Enquanto a formação da "unidade moral" citada por Franco não tomava corpo, ou seja, a organização de uma conspiração para a derrubada da Frente Popular contra a vitória eleitoral dos trabalhadores, o novo governo se iniciava presidido novamente por Manuel Azaña, com crises gestadas no seu interior com os diversos grupos de esquerda. Ou seja, a unidade de esquerda acabou por se constituir de forma momentânea, mas após o pleito eleitoral criou-se

\footnotetext{
62 Embora dispersas, as candidaturas da direita incluíram cedistas, carlistas, monarquistas, republicanos conservadores e mesmo membros da Falange. MORADIELLOS, Enrique. El reñidero de Europa. Las dimensiones internacionales de la guerra civil española. Barcelona: Ediciones Península, 2001, p. 41.

${ }^{63}$ Em grande medida, o conjunto de partidos considerados como de "centro" estavam constituídos por aqueles que não compactuavam com o conservadorismo extremo dos contrarrevolucionários ou as propostas revolucionárias dos membros da Frente Popular. Como foi o caso do Partido Nacionalista Vasco (PNV), Liga Catalana e o Partido del Centro Democrático (PDC), capitaneado pelo próprio primeiro-ministro Portela Valladares.

${ }^{64}$ PRESTON, Paul. Franco. A Biography. New York: BasicBooks, 1994, p. 117.
} 
um cenário de diversas oscilações, hesitações e escaramuças entre as esquerdas constitutivas da Frente Popular.

Azaña tomou posse no dia 18 de fevereiro e nomeou um gabinete republicano. De chofre anistiou os cerca de 30.000 prisioneiros políticos e em seguida foram suspensos os pagamentos de ocupação de terra em Extremadura e Andaluzia, como um dos atos direcionados a acelerar a retomada da reforma agrária. Ademais, também restaurou os governos de cunho socialista e a administração autônoma catalã que estava suspensa. E, tentou isolar os dois generais mais associados ao conservadorismo e à proposta de golpe que pairava com a vitória da Frente Popular. Francisco Franco foi removido para as Ilhas Canárias e o General Manuel Goded para as Ilhas Baleares no Mediterrâneo. ${ }^{65}$

Entretanto, a coalização de esquerda frentista não resistiu nos meses posteriores à vitória eleitoral. Com um grupo composto, em virtude das eleições, pela classe média, pelo operariado, por marxistas, socialistas e anarquistas, a sua fragmentação não tardou em acontecer. Pois, enquanto esses dois últimos grupos pretendiam superar o espectro reformista sob o qual havia iniciado a Frente Popular, os comunistas, oriundos do PCE, se enveredavam por assumir a vanguarda de um processo revolucionário.

O posicionamento comunista transparece nas palavras de Palmiro Togliatti:

\begin{abstract}
Mais de uma vez a posição dos anarquistas teve peso decisivo no curso da revolução espanhola. O abstencionismo dos anarquistas favoreceu a vitória das direitas nas eleições de 1933. A traição dos dirigentes anarquistas catalães permitiu ao estado uma fácil repressão da insurreição das Astúrias. Em muitos casos, os chefes anarquistas locais, ao mobilizar as massas sem nenhuma preparação séria, sem nenhum plano revolucionários sério e sem nenhuma perspectiva de êxito, objetivamente se alinharam com a reação e determinaram a extensão das divisões no seio do movimento trabalhadora e da desorientação e cansaço entre as massas.

Superar as divisões causadas pelos anarquistas e atrair de novo amplas massas de trabalhadores anarco-sindicalistas a uma frente única de luta contra o fascismo, é uma das tarefas mais importantes para o futuro da revolução, tarefa que a parte mais consciente do proletariado espanhol se propôs a alcançar. ${ }^{66}$
\end{abstract}

\footnotetext{
${ }^{65}$ JACKSON, Gabriel. "The Spanish Popular Front, 1934-7” In: Journal of Contemporary History, Vol. 5, No. 3, Popular Fronts (1970), p. 30.

66 "La Victoria del Frente Popular y el desarrollo de la Revolución en España" In: TOGLIATTI, Palmiro. Escritos sobre la guerra de España. El testimonio histórico del dirigiente extranjero que más influyó en la lucha contra el fascismo en España. Barcelona: Editorial Crítica, 1980. p. 51-52.
} 
Enquanto o PCE se movimentava para concentrar e trazer certa unicidade à Frente Popular, o Partido Obrero de Unificación Marxista (POUM), em fevereiro de 1936 expõe as suas considerações sobre o papel do Partido Comunista:

\begin{abstract}
Se começa a guerra entre a França e a Alemanha, os comunistas franceses, em virtude da política da Frente Popular, serão os treinadores no seio da massa trabalhadora favor da luta armada e em defesa do imperialismo alemão Na Espanha, a atuação oficial do Partido Comunista se conduz a posições parecidas. Os governos burgueses de esquerda encontram o mais firme apoio dos comunistas estalinianos. Praticamente esta política de proteção conduz ao frear da ação massas em marcha à revolução socialista. A burguesia de hoje tem um aliado de enorme valor: é o Partido Comunista com sua resoluta defesa da Frente Popular. ${ }^{67}$
\end{abstract}

E a respeito da participação do POUM na própria Frente Popular, que utilizou o conjunto de alianças como estratégia para um dos pontos de convergência da proposta frentista:

Se tratava, então, de um simples pacto eleitoral tendo como principal finalidade a Anistia. O POUM desenvolveu, então, sua propaganda com completa independência, assinalando que não poderia dar outra interpretação ao pacto assinado, senão de que é um compromisso pura e exclusivamente eleitoral. ${ }^{68}$

Enquanto que duas das principais organizações comunistas teciam suas tramas políticas para o governo da Frente Popular, os anarquistas apresentavam um outro viés para o governo frentista:

(...) é exato dizer que o governo da Frente Popular na Espanha nada mais é que o reflexo de um compromisso entre a pequena burguesia e o capitalismo internacional.

Pela mesma força dos fatos, esse compromisso tem apenas um valor transitório e deverá dar lugar às reivindicações e à linha de conduta estabelecidas com vistas a uma profunda transformação social.

Veremos então desaparecer a praga dos negociantes e dos conservadores que agem hoje à sombra dos republicanos e liberais de Barcelona, Valência e Madri. A ideia de substituir esses governos, guardiães débeis do status quo da propriedade e da finança estrangeiras, por um governo forte, baseado numa ideologia e numa organização política 'revolucionária', só poderia resultar num adiamento da explosão revolucionária.

Não se trata, portanto, nem de que o Marxismo tome o poder, nem de uma autolimitação da ação popular por oportunismo político. O 'Estado operário'

\footnotetext{
67 "Qué es y qué quiere el Partido Obrero de Unificación Marxista". Disponível em: 〈www.fundanin.org/POUM.htm>. Acesso em: 04 jul. 2016.

${ }^{68}$ Ibidem.
} 
constitui o ponto final de uma ação revolucionária e o começo de uma nova servidão. ${ }^{69}$

Os excertos acima apresentados, de membros ou organizações que compunham a Frente Popular, e mesmo no período que engloba os meses antecedentes e aqueles depois do início da Guerra Civil, apresentam a fratura interna existente no bloco vencedor das eleições de fevereiro de 1936. Ainda que em alguns momentos tenha havido o reconhecimento de que alianças, à guisa de exemplo, entre anarquistas e certos núcleos comunistas haviam caminhado para um caminho revolucionário $^{70}$, a chegada ao governo republicano alterou profundamente esse panorama.

Assim, como afirma Jackson, no intervalo entre fevereiro e junho, os diversos grupos de esquerda estabeleceram táticas "extra-legais". ${ }^{71}$ Ou seja, o combate entre as diversas vertentes da esquerda, que chegaram às vias de fato com a invasão de comitês políticos de ambos os lados. Enquanto as esquerdas se fragmentavam, o grupo conservador nas eleições se reorganizava em um ambiente interno extremamente desfavorável para as suas pretensões de retomada do status quo anterior.

Após a malfadada proposta de golpe militar e os atos de isolamento de militares envolvidos, no decorrer da primavera de 1936, se reiniciou a aproximação desses últimos com a vasta gama de conservadores derrotados em fevereiro. Além da "ameaça" que havia se tornado a Frente Popular com a hegemonia de esquerdas no controle governamental da Segunda República, o gatilho para um novo pronunciamento foi apertado com a morte de um dos principais líderes da direita espanhola: José Calvo Sotelo.

A consequência da morte de Sotelo, no contexto de embates entre falangistas e grupos de esquerda, levou a uma aceleração dos preparativos de uma sublevação, que vinha sendo organizada pelo General Emilio Mola Vidal e com substantivo apoio de guarnições militares comandadas por militares que haviam sido enviados para fora da península, como foi o caso de Francisco Franco.

\footnotetext{
69 "A inutilidade do Governo", Boletín de Informaciones C.N.T., n. 41, 03 de setembro de 1936. In: BROUÉ, Pierre. A Revolução Espanhola (1931-1939). São Paulo: Perspectiva, 1992, pp. 140-141.

${ }^{70}$ A própria CNT/FAI reconheceu o papel preponderante dos comunistas durante a Revolução Asturiana de 1934. Cf. Information Bulletin of the C.N.T. and F.A.I., n. 01, agosto de 1936. A dispersão de fontes anarquistas e a busca por um corpora mais completo foi uma dificuldades encontradas para a pesquisa. No entanto, destaca-se o Bibliotek der Freien. Anarchistiche Bücherei im Haus der Demokratie Berlin. Disponível em: <www.bibliothekderfreien.de/lidiap>. Acesso em: 07 jul. 2016. O site possui uma extensa coleção de publicações anarquistas, inclusive relacionadas à Guerra Civil Espanhola.

${ }^{71}$ JACKSON, Gabriel. "The Spanish Popular Front, 1934-7” In: Journal of Contemporary History, Vol. 5, n. 3, Popular Fronts (1970), p. 31.
} 
Em 17 de julho de 1936, se iniciou a sublevação militar contra o governo da Frente Popular com a movimentação de tropas na porção europeia-continental, nos arquipélagos mediterrânicos (Ilhas Baleares) e do Atlântico (Ilhas Canárias) e nas possessões espanholas no Norte da África.

\subsection{O estado paralelo sublevado: da militarização inicial à via espanhola do fascismo}

Com o avanço dos militares sublevados, de 17 de julho, sobre a porção continental do Estado espanhol, os aliados políticos e econômicos conservadores principiaram um movimento reacionário para impedir a manutenção das ações reformistas, adotadas no primeiro biênio republicano, e as propostas e políticas praticadas nos primeiros seis meses da Frente Popular. Ainda que os processos de transformações proporcionados pelas facetas progressistas do governo republicano, como foi o caso da incipiente reforma agrária e direitos mínimos aos trabalhadores, se caracterizassem em alguns aspectos de forma emergencial e mesmo imediatista, o objetivo dos insurgentes era o retorno às condições pré-1931. Não havia espaço, no interior do Movimiento, como foi denominado pelos próprios insurgentes, para propostas de transformação societária mesmo que fossem derivadas de sistemas liberais e democráticos. $^{72}$

A estratégia para a derrota republicana se apresentou por meio de uma tentativa acelerada de conquistar Madri e a consequente restauração do poder nas mãos da conservadora elite espanhola. Entretanto, no decorrer das primeiras semanas de combate, percebeu-se que uma vitória sobre a Frente Popular, o governo republicano e as forças dos trabalhadores não seria obtida de modo tão rápido quanto foi inicialmente imaginado. $\mathrm{O}$ caráter reativo do governo republicano nas esferas internas e externas da política, a afirmação de movimentos revolucionários de operários e camponeses e a própria manutenção de uma pequena parcela do Exército na defesa da capital, foram algumas das circunstâncias que impediram a derrota imediata do governo de Madri.

Diante desse cenário, dois pontos pareceram peremptórios para os rebelados: internamente, a construção de organismos de administração nas áreas que estavam a ser controladas; e, de forma concomitante, no campo internacional, o reconhecimento do "novo Estado espanhol" pela comunidade internacional. Ou seja, o caminho adotado foi de "afirmações de sua própria legalidade" como salientou Pierre Vilar. ${ }^{73}$

\footnotetext{
${ }^{72}$ BRICALL, Josep M. "La Economía Española (1936-1939)” In: TUÑON DE LARA, Manuel et alii. La Guerra Civil Española. 50 años después. Barcelona: Labor, 1989, p. 365.

${ }^{73}$ VILAR, Pierre. A Guerra da Espanha (1936-1939). Rio de Janeiro: Paz e Terra, 1989, p. 76.
} 
Internamente, os sublevados começaram a instituir de forma autocrática um conjunto de normas administrativas, jurídicas e econômicas que passaram a coexistir com o corpo constitucional republicano e com a criação de "fronteiras" que se constituíam pari passu aos desdobramentos dos avanços militares. No decorrer do intervalo entre a sublevação de julho e o fim dos combates em março de 1939, a trajetória das constituições administrativas perpassaram das formas precárias iniciais, essencialmente em 1936, e a formatação de uma estrutura estatal paralela ao governo republicano: a Junta de Defensa Nacional, a Junta Técnica del Estado, e o Primero Gobierno de Franco ou como ficou conhecido, o Gobierno de Burgos.

A primeira das estruturas insurgentes e que impetrou atos e decretos de forma autônoma àquela existente em Madri, foi a Junta de Defensa Nacional que perdurou no decorrer dos três primeiros meses e instituiu os atos iniciais de controle sobre as regiões ocupadas. Criada em 24 de julho e já sediada em Burgos, cidade que se constituiria no decorrer do conflito na sede dos inimigos do governo republicano, a sua organização foi elaborada em decorrência do fracasso em tomar o poder nas 48 horas após o início do levante. Inicialmente, a Junta seria controlada pelo General José Sanjurjo Sacanell, o mesmo da tentativa do pronunciamiento de 1932. No entanto, com a sua morte, após um acidente aéreo ao retornar do exílio em Portugal, assumiu o general de maior antiguidade, Miguel Cabanellas Ferrer.

Nas suas primeiras semanas de existência, a Junta publicou decretos que envolveram a destituição dos governadores civis, mesmo que de forma retroativa ao dia 19 de julho, e a declaração de Estado de Guerra nos territórios sob o controle militar. ${ }^{74}$ Formada inicialmente por militares de maior patente, ela era o próprio reflexo do avanço reacionário da insurgência em curso. Os seus membros mais proeminentes eram militares oriundos, principalmente, do antigo Exército monárquico e vinculados principalmente a uma noção de primazia religiosa católica como condutora do Estado espanhol.

Além da fração rebelada das Forças Armadas do Estado espanhol, houve a formação de milícias com grande contingente de membros de origem falangista, cedista e de outros grupos de menores expressão vinculados a posicionamentos conservadores.

Se as ações militares não alcançavam a celeridade necessária para o pleno domínio do Estado espanhol, as regiões iniciais que iam sendo ocupadas sofriam um processo de expurgo dos representantes do governo republicano, por meio da exclusão de quadros administrativos

74 "Decreto núm 14", "Decreto núm. 15". In: Boletín oficial de la Junta de Defensa Nacional de España, Burgos 30/07/1936, n. 3. 
locais pertencentes ao governo de Madri. E, vinculado a esse processo, houve a criação de execuções, na maioria delas de forma generalista - ser minimante "simpatizante" das propostas republicanas - como uma outra tônica do processo de militarização. ${ }^{75}$

Esse processo de constituição de uma estrutura militarizada vinculava-se a um princípio que se expunha como "apolítico". ${ }^{76}$ A ideia de um pretenso apoliticismo por parte dos militares revoltosos se concentrou na ideia de que as propostas de alteração, ainda que restritas, da sociabilidade espanhola por parte do governo republicano representava a própria noção de política. E, o caminho da militarização seria o viés pelo qual seria possível obter a subjugação da população civil.

A composição militarizada da Junta de Defensa Nacional nos dias seguintes à insurgência, com a divisão exclusiva dos poderes transformou o corpo militar espanhol revoltoso em um demiurgo dos anseios conservadores. Eles se tornaram a síntese e incorporaram a necessidade de que fossem superadas tais possibilidades de divisões internas que existiram nos primeiros anos da Segunda República. A superação de cânones liberais e as diversas tendências igualitaristas de revolução proletária se constituíram no moto sublevado, com a noção do "apolítico" indissociável do movimento autocrático dos militares.

Esse caráter se tornou bastante claro com a composição do primeiro gabinete, ainda que improvisado, dos militares golpistas:

\footnotetext{
${ }^{75}$ Cf. ESPINOSA, Francisco y LEDESMA, José Luis "La violencia y sus mitos" In: VIÑAS, ÁNGEL. En El Combate por la Historia. La República, La guerra civil, el franquismo. Barcelona: Pasado \& Presente, 2012 pp. 475-497. Em seu texto, os autores realizam um balanço quantitativo das execuções e fuzilamentos por parte dos golpistas e da violência por parte do governo republicano. A compilação dos números de mortos - 130.199 executados pelo bando franquista e 49.272 por republicanos - com origem documental de diversos historiadores, fontes oficiais e as descobertas de valas comuns feitas pela Ditadura de Franco, mostram, no decorrer da guerra civil, a sua dinâmica repressiva sistematizada e institucionalizada.

${ }^{76}$ Cf. GALLEGO, Ferran "La evolución política de la zona sublevada" In: VIÑAS, Angel (Ed.). En el combate por la historia. La República, la Guerra Civil, el franquismo. Barcelona: Pasado \& Presente, 2012, pp. 311-333.
} 


\begin{tabular}{|c|c|c|}
\hline \multicolumn{3}{|c|}{$\begin{array}{l}\text { 1.1. Membros da Junta de Defensa Nacional } \\
(24 / 07 / 1936-03 / 10 / 1936)\end{array}$} \\
\hline Patente militar e nome & Cargo & Data de ingresso \\
\hline General de Divisão Miguel Cabanellas Ferrer & Presidente & $24 / 07 / 1936$ \\
\hline General de Divisão Andrés Saliquet Zumeta & Vocal & 24/07/1936 \\
\hline General de Brigada Miguel Ponte y Manso de Zúñiga & Vocal & $24 / 07 / 1936$ \\
\hline General de Brigada Emilio Mola Vidal & Vocal & 24/07/1936 \\
\hline General de Brigada Fidel Dávila Arrondo & Vocal & $24 / 07 / 1936$ \\
\hline Coronel do Estado-Maior Federico Montaner Canet & Vocal & $24 / 07 / 1936$ \\
\hline Coronel de Estado-Maior Fenando Moreno Calderón & Vocal & $24 / 07 / 1936$ \\
\hline General de Brigada Germán Gil Yuste & Vocal & $29 / 07 / 1936$ \\
\hline Capitán de Navio Francisco Moreno Fernández & Vocal & $30 / 07 / 1936$ \\
\hline General de Brigada (reserva) Alfredo Kindelán Duani & Vocal & 29/07/1936 \\
\hline General de Divisão Francisco Bahamonde Franco & Vocal & 03/08/1936 \\
\hline General de Divisão Gonzalo Queipo de Llano y Sierra & Vocal & $19 / 09 / 1936$ \\
\hline General de Brigada Luiz Orgaz Yoldi & Vocal & 19/09/1936 \\
\hline
\end{tabular}

Fontes: Boletín oficial de la Junta de Defensa Nacional de España, Burgos 25/07/1936, no. 1, Boletín oficial de la Junta de Defensa Nacional de España, Burgos 30/07/1936, no. 3, Boletín oficial de la Junta de Defensa Nacional de España, Burgos 04/08/1936, no. 4, Boletín oficial de la Junta de Defensa Nacional de España, Burgos 19/09/1936, n. 24. Disponível em: 〈www.boe.es〉. Acesso em: 22 mai. 2016. (Adaptado pelo autor)

Durante esses três primeiros meses de avanço sublevado, além do fracasso em conquistar rapidamente a capital e destituir o poder governo republicano, a Junta de Defensa Nacional começou a sofrer os efeitos da falta de um comando centralizado, mesmo com a proposta de militarização social em voga. Ora pela própria característica hierárquica do corpo militar, ora pela própria necessidade de organização de uma estratégia unificada, ou ainda pela diferença de gerações do oficialato, se iniciaram diversas disputas internas pelo seu controle.

A solução para a fragmentação que se iniciava no interior do agrupamento militar sublevado foi a realização de eleições entre os principais oficiais e membros da Junta. O pleito interno, de 29 de setembro, determinou a nomeação do então comandante das tropas das Ilhas Canárias, General Francisco Franco, em “Generalissímo”. Ao assumir a Junta Tecnica del Estado, concentrou todos os poderes do novo Estado e chefe das forças nacionais de terra, ar 
e mar. ${ }^{77}$ A deliberação ainda assinada por Cabanellas, mas que se absteve na votação por ser contrário à ascensão de Franco, justificava o caminho centralizador do golpe militar:

Organizada com prefeita normalidade a vida civil nas províncias resgatadas e estabelecido o laço entre as várias frentes dos Exércitos que lutam pela salvação da Pátria, desta vez pela causa da civilização, já se impõe um novo regime orgânico e eficiente, que responda adequadamente à nova realidade espanhola e prepare com a máxima autoridade, seu porvir. ${ }^{78}$

Se por um lado, o lento desenho de uma arquitetura de um estado de viés fascista começou a ser elaborado com a centralização do poder insurgente na figura do General Francisco Franco, igualmente a lógica de administração dos espaços exclusivamente controlados por militares apresentou profundas alterações. Ato contínuo à sua nomeação como Chefe de Estado e ao desfile de $1^{\circ}$ de outubro de 1936 em Burgos, houve a criação de um novo formato proto-governamental por meio da criação da Junta Técnica del Estado.

Com as atribuições instituídas pela nova Junta, é possível visualizar o encadeamento conservador entre as diversas comissões. Na maioria das descrições apresentadas pela nova organização sublevada e já sob o pleno controle de Francisco Franco. Além da própria organização burocrático-administrativa, foram também apresentadas ações repressivas: intervenções educacionais, submissão dos trabalhadores e "colaboração" com os demais elementos produtivos, estabelecimento de patrimônios particulares, expressão que se vinculava diretamente à uma regressão na reforma agrária que esteve em curso no governo republicano.

Em grande medida, a maioria desses atos foram realizados na última quinzena de setembro, ou seja, uma preparação em se superar o Estado provisório existente entre julho e setembro de 1936. Assim, se organizou a institucionalização dos anseios não só do Exército, mas das facções conservadoras e reacionárias do Estado espanhol.

No caso da educação, em setembro se aprofundou perseguições e expurgos no interior das universidades, escolas primárias e secundárias. A tentativa era excluir das regiões ocupadas todos os intelectuais associados ao conceito generalizado de "republicanos".

Os professores cujos informes sejam totalmente desfavoráveis por suas atuações anteriores, não só em seu aspecto perturbador das consciências

\footnotetext{
77 “Decreto núm. 138” In: Boletín oficial de la Junta de Defensa Nacional de España, Burgos 30/09/1936, n. 32.
}

${ }^{78}$ Ibidem. 
infantis, mas também por sua conduta amoral ou antipatriótica, serão imediatamente suspensos do emprego e salário. ${ }^{79}$

De forma coordenada à expulsão de centenas de professores, ${ }^{80}$ houve o rompimento do laicismo estatal na matéria educacional e que os inspetores e agentes da Junta,

(...) só autorizarão, nas escolas primárias, as obras cujo conteúdo responda aos sãos princípios da Religião e moral cristã, dando a entender claramente, que a Escola Nacional deixou de laica, mas perante às dúvidas surgidas, se esclarece explicitamente que o ensino da Religião e História Sagrada são obrigatórias e formam parte do labor escolar. ${ }^{81}$

As determinações de submissão e controle dos trabalhadores aos sublevados se consolidaram às vésperas da criação da Junta Técnica, com a proibição de todas as atuações políticas e sindicais:

O interesse supremo da Espanha e os heroicos serviços que tantos espanhóis de boa vontade vem prestado, exige, a todo custo, manter a fervorosa união de todos os cidadãos enquanto o Exército assuma os Poderes do Estado, aniquilando se preciso for, todo ramo de atividades ou de parcialidades política ou sindicais de partido (...). Chegará o dia no qual o Governo que conduza os destinos da Espanha saberá desenvolver a única política e a única sindicalização possível em toda a Nação bem organizada: a política e a sindicalização que conduzam e controlem os diretores da coisa pública como depositários da confiança do povo. ${ }^{82}$

Os decretos e imposições publicadas às vésperas da criação da Junta Técnica del Estado, as atribuições das comissões que formavam o governo paralelo que se instituiu em Burgos já se apresentavam delimitadas antes mesmo de seu início:

\footnotetext{
79 “Circular" In: Boletin Oficial de La Junta de Defensa Nacional de España. Burgos, 19/09/1936, n. 24, p. 96.

${ }^{80}$ As listas de expulsão praticamente permearam todas as publicações do Boletin Oficial de La Junta de Defensa Nacional de España. Burgos no decorrer do mês de setembro de 1936.

81 "Orden 186 del 21 de septiembre de 1936" In: Boletin Oficial de La Junta de Defensa Nacional de España. Burgos, 24/09/1936, n. 27, p. 107.

82 "Decreto núm. 131" In: Boletin Oficial de La Junta de Defensa Nacional de España. Burgos, 28/09/1936, n. 30, p. 118.
} 


\begin{tabular}{|c|c|}
\hline \multicolumn{2}{|r|}{$\begin{array}{l}\text { 1.2. Atribuições da Junta Técnica del Estado } \\
\qquad(03 / 10 / 1936-31 / 01 / 1938)\end{array}$} \\
\hline Comissão/Cargo & Descrição das Atribuições \\
\hline Presidente & $\begin{array}{l}\text { Resolverá os diversos assuntos atribuídos às comissões, presidirá suas } \\
\text { reuniões (da Junta) parciais ou totais, organizará a cooperação de } \\
\text { técnicos com caráter consultivo que forem nomeados oportunamente e } \\
\text { submeterá suas resoluções à aprovação do Chefe de Estado }\end{array}$ \\
\hline Governador Geral & $\begin{array}{l}\text { Inspeção das províncias ocupadas e do que fosse relacionado à vida } \\
\text { cidadã, proventos, trabalho e benfeitorias, em estreita relação com as } \\
\text { autoridades das mesmas e os com os correspondentes departamentos da } \\
\text { Junta Técnica del Estado. }\end{array}$ \\
\hline $\begin{array}{l}\text { Secretaria de Relações } \\
\text { Exteriores }\end{array}$ & $\begin{array}{l}\text { Tem a seu cargo a seu cargo as questões diplomáticas e consulares com } \\
\text { os demais países e uma seção de imprensa e propaganda, que será } \\
\text { presidida por um Chefe que dependerá diretamente do Chefe de Estado. }\end{array}$ \\
\hline $\begin{array}{l}\text { Secretaria Geral do } \\
\text { Chefe de Estado }\end{array}$ & $\begin{array}{l}\text { Composto por pessoal especialista nas matérias que são objeto das } \\
\text { distintas seções da Junta Técnica e com um membro destacado do } \\
\text { departamento de Relações Exteriores. }\end{array}$ \\
\hline Comissão de Fazenda & $\begin{array}{l}\text { Estudo e preparação de divisas, donativos, impostos, contribuições, } \\
\text { bancos, Tesouro Nacional, Aduana, rubricas, orçamentos, Câmaras de } \\
\text { compensação, impostos alfandegários, monopólios, operações de crédito } \\
\text { e de gastos }\end{array}$ \\
\hline Comissão de Justiça & $\begin{array}{l}\text { Proposição de normas que na atual ordem processual não tem aplicação } \\
\text { tangível, bem como a modificação ou alteração daquelas vigentes. }\end{array}$ \\
\hline $\begin{array}{l}\text { Comissão de Indústria, } \\
\text { Comércio e Provisões }\end{array}$ & $\begin{array}{l}\text { Estudo estatístico das diversas atividades, mercadorias e provisões } \\
\text { existentes nas províncias ocupadas, regime de coordenação entre as } \\
\text { mesmas e auxílios que necessitem, fomento das exportações e } \\
\text { determinação das importações necessárias, assim como arbitrar os } \\
\text { primeiros meios para a subsistência das indústrias. }\end{array}$ \\
\hline $\begin{array}{l}\text { Comissão de Agricultura } \\
\text { e Trabalho Agrícola }\end{array}$ & $\begin{array}{l}\text { Fixar as normas indispensáveis para a continuação das atividades } \\
\text { agrícolas e preparar a revalorização dos produtos da terra, } \\
\text { estabelecimentos de patrimônios familiares, cooperativas agrícolas e } \\
\text { melhoras na vida camponesa. }\end{array}$ \\
\hline Comissão de Trabalho & $\begin{array}{l}\text { Tudo o que compete ao relacionado com as bases vigentes e relatórios de } \\
\text { trabalho e o estudo de novas orientações que destinadas ao bem-estar da } \\
\text { classe trabalhadora e a colaboração desta com os demais elementos da } \\
\text { produção. }\end{array}$ \\
\hline $\begin{array}{l}\text { Comissão de Cultura e } \\
\text { Ensino }\end{array}$ & $\begin{array}{l}\text { Assegurar a continuidade da vida escolar e universitária, reorganização } \\
\text { dos centros de ensino e estudos das modificações necessárias para adaptá- } \\
\text { los às novas orientações do novo Estado. }\end{array}$ \\
\hline $\begin{array}{l}\text { Comissão de Obras } \\
\text { Públicas e } \\
\text { Comunicações }\end{array}$ & $\begin{array}{l}\text { Missão de assegurar a continuação das obras públicas em curso, } \\
\text { empreender novas obras onde seja indispensável, reestabelecer as linhas } \\
\text { de transporte de todos os tipos, organizar um perfeito serviço de } \\
\text { comunicações postais e telegráficas para toda a região ocupada, assim } \\
\text { como o pessoal necessário para estes serviços. }\end{array}$ \\
\hline
\end{tabular}

Fonte: “Gobierno del Estado, Ley” In: Boletin Oficial del Estado, Año 1, 02/10/1936, núm 1, pp. 1-2. (Adaptado pelo autor) 
Com a organização dos nódulos internos da Junta direcionados à construção de um corpo burocrático controlado, normatizou-se também a estratégia de ação externa com a criação de uma Secretaria de Relações Exteriores, que nas suas atribuições assumia o ambiente externo como preponderante para a constituição do Estado sublevado. E estrategicamente atrelado ao Chefe de Estado, Francisco Franco. Embora Francisco de Assis Serrat y Bonastre tenha se tornado o titular da pasta ministerial de Relações Exteriores, a ligação umbilical com as pretensões de Franco, fez com que este assumisse para si as ações no campo externo. À sombra de Serrat y Bonastre, estava o próprio irmão de Franco, Nicolás, que participava de forma mais incisiva das negociações externas.

\begin{tabular}{|c|c|c|c|}
\hline \multicolumn{4}{|c|}{$\begin{array}{l}\text { 1.3. Membros da Junta Técnica del Estado } \\
(03 / 10 / 1936-31 / 01 / 1938)\end{array}$} \\
\hline \multirow{2}{*}{ Cargo } & \multirow{2}{*}{ Nome } & \multicolumn{2}{|c|}{ Mandato } \\
\hline & & Início & Fim \\
\hline Chefe de Estado & Francisco Franco & $30 / 09 / 1936$ & $31 / 01 / 1938$ \\
\hline Presidente (s) & Fidel Dávila Arrondo & 03/10/1936 & $03 / 06 / 1937$ \\
\hline & Francisco Gómez-Jordana Sousa & 03/06/1937 & $31 / 01 / 1938$ \\
\hline Secretaria de Relações Exteriores & Francisco de Asis Serrat y Bonastre & $01 / 10 / 1936$ & $30 / 01 / 1938$ \\
\hline Comissão de Justiça & José Cortés Lopez & 03/10/1936 & $31 / 01 / 1938$ \\
\hline Comissão de Fazenda & Andrés Amado & $05 / 10 / 1936$ & $31 / 01 / 1938$ \\
\hline $\begin{array}{l}\text { Comissão de Indústria, Comércio e } \\
\text { Provisões }\end{array}$ & Joaquim Bau Nolla & $05 / 10 / 1936$ & $31 / 01 / 1938$ \\
\hline $\begin{array}{l}\text { Comissão de Agricultura e Trabalho } \\
\text { Agrícola }\end{array}$ & Eufemio Olmedo Ortega & 05/10/1936 & $31 / 01 / 1938$ \\
\hline Comissão de Trabalho & Alejandro Gallo Artacho & $04 / 10 / 1936$ & $31 / 01 / 1938$ \\
\hline Comissão de Cultura e Ensino & José María Pemán y Permatín & $05 / 10 / 1936$ & $31 / 01 / 1938$ \\
\hline $\begin{array}{l}\text { Comissão de Obras Públicas e } \\
\text { Comunicações }\end{array}$ & Mauro Serret Y Mirete & $05 / 10 / 1936$ & $31 / 01 / 1938$ \\
\hline
\end{tabular}

A organização da Junta Técnica del Estado apresentou uma característica marcante que foi a formação de um gabinete composto por civis, enquanto que a maioria do corpo militar foi removido para postos e cargos voltados exclusivamente à esfera militar. ${ }^{83}$ Esta nova

\footnotetext{
${ }^{83}$ De acordo com as determinações de Franco, assim se situaram os antigos membros da Junta de Defensa Nacional em cargos relacionados à nova estrutura estatal que tentavam impor: Miguel Cabanellas (Inspetor Geral do Exército), Fidel Dávila que acumulou inicialmente com o cargo de presidente da Junta (Chefe geral do Estado-
} 
composição se vestia de dois sentidos: o afastamento dos militares da esfera administrativa do Estado e que de alguma forma poderia ameaçar o poder alcançado por Franco; e, os membros que compõe a nova Junta vinculavam-se aos grupos conservadores que apoiaram o levante de julho de 1936.

O caráter "provisório" da Junta Técnica del Estado terminou em 30 de janeiro de 1938, com a criação de uma estrutura estatal que foi concebida como a Administração Central do Estado. A superação das formas anteriores de administração, consolidou de jure um Estado paralelo. O cenário que anteriormente havia sido ensaiado pela Junta Técnica del Estado se concretizou com o decreto publicado por Francisco Franco:

(...) apesar do esforço dos homens a serviço daquela organização, exclusivamente administrativa, a normalidade da vida pública na parte liberada do solar da Pátria, o volume e a complexidade crescente das funções de governo e de gestão, e a necessidade de ter construído de modo completo o sistema administrativo, aconselham a reorganização dos serviços centrais que, sem pré-julgar uma definitiva forma do Estado, abra razão à realização de uma obra de governo estável, ordenada e eficaz. ${ }^{84}$

De acordo com o publicado e os cargos iniciais designados, percebe-se que as transformações ocorridas se pautaram por uma organização que após o fim da guerra se tornaria o núcleo da Ditadura franquista. Abaixo segue a composição inicial do Primeiro Governo de Franco ou como foi mais conhecido, o Gobierno de Burgos:

Maior), Luis Orgaz y Yoldi (Alto Comissário da Espanha no Marrocos e Chefe superior das forças na África). Os outros membros foram deslocados para o comando de tropas. Cf. Boletin Oficial del Estado, Año 1, 02/10/1936, núm 1, pp. 1-3.

84 “Gobierno del Estado. Ley.” In: Boletín Oficial del Estado. Burgos, 31/01/1938, núm. 467, p. 5514. 


\begin{tabular}{|c|c|}
\hline \multicolumn{2}{|c|}{$\begin{array}{l}\text { 1.4. Primeira composição do Gobierno de Burgos } \\
\qquad(31 / 01 / 1938)\end{array}$} \\
\hline Cargos & Titulares \\
\hline Chefe de Estado e Presidente do Governo & General Francisco Franco Bahamonde \\
\hline $\begin{array}{l}\text { Vice-presidente e Ministro de Assuntos } \\
\text { Exteriores }\end{array}$ & Tenente-Coronel Francisco Gómez-Jordana Sousa \\
\hline $\begin{array}{l}\text { Ministro da Agricultura e Ministro-Secretário } \\
\text { Geral do Movimento }\end{array}$ & Raimundo Fernández Cuesta y Merelo \\
\hline Ministro da Defesa & General Fidel Dávila Arrondo \\
\hline Ministro de Educação Nacional & Pedro Sainz Rodríguez \\
\hline Ministro da Fazenda & Andrés Armado y Reygondaud de Villebardet \\
\hline Ministro de Indústria e Comércio & Juan Antonio Suanzes Fernández \\
\hline Ministro do Interior & Ramón Serrano Suñer \\
\hline Ministro da Justiça & Tomás Domínguez Arévalo \\
\hline Ministro de Obras Públicas & Alfonso Peña Boeuf \\
\hline Ministro da Ordem Pública & Severiano Martínez Anido \\
\hline Ministro de Organização e Ação Sindical & Pedro González-Bueno y Bocos \\
\hline
\end{tabular}

Fonte: Decretos 443 a 453. In: Boletin Oficial del Estado, Año 1, 01/02/1936, núm. 468, p. 5547. (Adaptado pelo autor)

O caráter do Gobierno de Burgos, já havia se mostrado antes mesmo de sua criação formal, em janeiro de 1938. No decorrer de 1937, ocorreu o processo de aglutinação em torno da Junta Técnica e, sobretudo, do General Franco, dos grupos conservadores existentes no interior do Estado espanhol, principalmente a CEDA e a Falange Española Tradicionalista y de las Jornadas Ofensivas Nacional Sindicalistas (FET y de las JONS). No caso dessa última, após a morte de seu fundador, José Antonio Primo de Rivera, o comando do partido havia ficado com Raimundo Fernández Cuesta. Dessa forma, um levante militar que na aparência se colocava como "apolítico", ou ainda de "salvação da Pátria espanhola contra a subversão comunista". A partir de novembro de 1937, por meio de um decreto, Franco estabeleceu que os falangistas e suas organizações seriam absorvidas pela administração militar. Ou seja, a travessia definitiva da constituição da via fascista espanhola que havia começado em outubro de 1936, alcançou a outra margem nos últimos dias de 1938.

As necessidades da autonomia falangista para se controlar as regiões mais distantes de Burgos ou de pequenas localidades, foi substituída pela própria absorção do grupo pela primeira administração do governo paralelo controlado pelo General Francisco Franco. A partir de 1938, a Falange se tornou o partido único e de controle social do Estado franquista que se formava. 
Além da utilização da FET y de las JONS como um dos pilares do Estado paralelo franquista, uma das peças essenciais para a sua manutenção, como foi exposto no quadro acima, a nomeação de Ramón Serrano-Suñer, como Ministro do Interior, também serviu a esse propósito. Aquele que seria conhecido como o Cuñadisímo (por ser cunhado de Carmem Polo, esposa de Franco), foi um dos responsáveis diretos em construir, no último ano da Guerra Civil e após o fim do conflito, em março de 1939, a variante espanhola do fascismo.

Um dos nódulos sociais controlados pela Falange Española Tradicionalista y de las J.O.N.S. foi o Fuero del Trabajo. O documento criado dois meses após a criação do Gobierno de Burgos apresenta duas características essenciais: traços que o colocam no mesmo patamar que os documentos clássicos do fascismo italiano, como o Estado total, corporativo e militarizado; e, por outro, especificidades que dão guarida a um caminho específico para a "via espanhola do fascismo":

(...) o Estado Nacional enquanto é instrumento totalitário a serviço da integridade pátria, e Sindicalista enquanto representa uma reação contra o capitalismo liberal e o materialismo marxista, empreende a tarefa de realizar - com ar militar, construtivo e gravemente religioso - a Revolução que a Espanha tem pendente.

(...)

E partindo de uma concepção da Espanha como unidade de destino, manifesta, (...) também que a produção espanhola - em irmandade de todos os seus elementos - seja uma Unidade que servia à fortaleza da Pátria e sustenha os instrumentos de seu poder. ${ }^{85}$

O caráter fascista do Estado implementado por Franco e por Suñer traz à tona algumas questões sobre a sua natureza e o próprio desenrolar do cenário no Estado espanhol, tanto no decorrer da Guerra Civil, bem como no regime ditatorial, implementado em 1939, que se findou com a transição negociada após a morte de Franco em 1975.

\subsection{Sublevados: dinâmica interna e o apoio externo nos campos militar e econômico}

Desde o início do Golpe de 17 de julho, as regiões sublevadas tomaram como ação pragmática inicial a retomada da estrutura econômica que havia sido objeto de mudança, seja pela lógica reformista, que havia imperado desde o começo da República, ou pelas poucas mudanças que ocorreram com a Frente Popular. Os insurgentes buscaram reestruturar o intervencionismo econômico e o domínio sobre todas as atividades e recursos minerais e

85 “Decreto: Fuero del Trabajo, 09/03/1938." In: Boletín Oficial del Estado. Burgos, 10/03/1938, núm. 505, p. 6178-6181. 
agrícolas. Essa linha geral de conduta no campo econômico atendia às elites locais, distribuídas em território espanhol, e que haviam perdido seu controle produtivo devido à reforma agrária, ainda que não tivesse ocorrido de forma tão profunda quanto se desejava. E, ademais, principiava os itens programáticos de partidos e grupos fascistas que se comportavam como antiliberais.

O processo paulatino de forte intervenção econômica, em curso desde os primeiros dias após a sublevação, não podia se restringir somente às demandas civis, mas também deveria se voltar para ganhar o conflito bélico que se estendia. Dessa maneira, o conjunto de decisões econômicas que possuiu um corte militar, também deveria criar uma economia de guerra. ${ }^{86} \mathrm{E}$, indubitavelmente, a construção de formas estatais por parte dos revoltosos que culminou, em 1938, com a criação de uma plena estrutural governamental paralela à de Madri, e as políticas econômicas adotadas no interior de cada uma delas, têm suma importância no aspecto de se criar uma economia de guerra.

Os movimentos ocorridos na ocupação ocorreram em áreas que eram essencialmente agrícolas, como, aliás, era a quase totalidade do Estado espanhol. Os principais centros urbanos com sólidas plantas industriais e financeiras - Madri, Barcelona, Bilbao - estiveram sob o controle republicano na maior parte do conflito. Assim, a sublevação dependeu do apoio externo para a sua continuidade, que foi obtido, principalmente, junto à Alemanha nazista, Itália e, em menor escala, à Portugal.

A trajetória da criação e desenvolvimento da economia insurgente pode ser observada a partir de três fases distintas. ${ }^{87}$

Uma primeira fase, que abordamos parcialmente no começo deste capítulo, compreendeu o período entre a noite de 17 de julho até meados de novembro, após a constituição da Junta Técnica del Estado em Burgos. Nesse intervalo temporal, com os territórios ocupados sendo administrados pela primeira estrutura provisória, a Junta de Defensa Nacional, a precariedade e o controle de regiões mais distantes de Madri apenas permitia, por um lado, o apoio imediato dos caciques locais e o fornecimento imediato de insumos alimentícios e de matérias primas; e, por outro lado, a falta de uma alta concentração de indústrias de transformação impedia o acesso a bens de origem fabril ou a possibilidade de

\footnotetext{
${ }^{86}$ SÁNCHEZ ASIAÍN, José Ángel. La financiación de la guerra civil española. Una aproximación histórica. Barcelona: Crítica, 2012, p.8.

87 VIÑAS, Angel et al. Política Comercial Exterior en España (1931-1975). Madrid: Servicios de Estudios Económicos, Banco Exterior de España, 1979, 2 vols., pp. 142-143. Adotamos a divisão realizada pelo autor. Embora ela apresente alguns traços generalizantes, foi essencial para que fosse possível apresentar os desdobramentos pertinentes para o desenvolvimento do trabalho.
} 
transformação de plantas fabris para a indústria bélica. Assim, a ocupação inicial dos territórios impedia a plena institucionalização da produção industrial de se voltar para uma economia de guerra.

No espaço desses quatros primeiros meses, a facção sublevada do Exército consolidou os seus primeiros atos internos. Além de criar controles autônomos na produção e circulação de divisas, também se constituiu o cerne da aliança com os governos da Alemanha e Itália.

No âmbito interno, com o controle de províncias e regiões geradoras de excedentes agrícolas e de criação bovina, foi possível o estabelecimento de um horizonte a médio prazo para abastecimento das tropas e da população, sem que se necessitasse de importações para tal fim. Entretanto, as regiões agrícolas controladas inicialmente não possuíam altos índices de produtividade. Uma das tentativas de abastecer as regiões ocupadas, sem aprofundar a dependência do comércio externo, foi a reversão dos produtos que então eram exportados, como foi o caso daqueles produzidos nas Ilhas Canárias, como o azeite de oliva e a cortiça. ${ }^{88}$

Dentro do princípio de intervencionismo interno adotado pelos militares, um dos primeiros atos foi, além da derivação do comércio para as áreas controladas, o aproveitamento objetivo sobre as poucas divisas e produtos disponíveis. Os primeiros envolveram o controle da produção do trigo, em 28 de julho, sobre o fluxo externo de ouro (14 de agosto) e de preços e produção industrial, em 17 de agosto. Em 14 de setembro constituem um Conselho próprio para o Banco de España e anulam, a partir do dia 25 do mesmo mês, todas as disposições salariais e agrárias que haviam sido criadas desde 12 de fevereiro. ${ }^{89}$

O ponto de partida para as decisões, acima expostas, ganharam contornos “institucionais" com a declaração unilateral de Estado de Guerra em 28 de julho e que abrangia todo o território espanhol. Além da lógica repressiva estatal contida na declaração, houve a delimitação inicial do controle sobre trabalho e a produção. No artigo sexto, dois itens abordam de forma objetiva as questões econômicas e seriam considerados inimigos aqueles que,

E) Os que se inclinem a impedir ou dificultar o abastecimento de artigos de primeira necessidade, elevem injustificadamente os preços dos mesmos ou de algum modo contribuam para o seu encarecimento

F) Os que impeçam a liberdade de contratação ou de trabalho ou que abandonem este, mesmo que se trate de empregados, patrões ou operários. ${ }^{90}$

\footnotetext{
${ }^{88}$ VIÑAS, Angel et al. Política Comercial Exterior en España (1931-1975). Madrid: Servicios de Estudios Económicos, Banco Exterior de España, 1979, vol. 1, p. 142.

${ }^{89}$ VILAR, Pierre. La guerra civil española. 5a. Ed. Barcelona: Crítica, 2010, p. 121.

90 "Bando" In: Boletin Oficial de La Junta de Defensa Nacional de España. Burgos, 30/07/1936, n. 3, p. 9.
} 
O controle sobre o fluxo externo de ouro, que havia ficado com o governo republicano, tornou-se um dos pontos centrais ao princípio do conflito. Com clara intenção de impedir que continuasse a ser utilizado na obtenção de recursos externos para a Segunda República e que fosse utilizado para a precária economia de guerra que se instalava, a Junta de Defensa Nacional definiu que:

O caráter delitivo das exportações de ouro da Nação, depositado no Banco de España, quando se está realizando por ordem de quem, nem sequer nominalmente, exercem jurisdição sobre a totalidade do território nacional, é evidente.

(...)

Se declara delito de traição o acontecido com as exportações de ouro do Banco de España que se tenham efetuado até esta data e que se realizem em seguida, assim como as que puderem existir procedentes dos bancos privados ou de particulares. $^{91}$

A partir da tentativa inicial de estancar a saída de ouro para o exterior que o governo republicano já utilizava em suas tentativas de obter armamentos, principalmente de aviação junto à França, outras medidas foram adotadas. Em adição à saída de divisas para o exterior, adotou-se a proibição de que fossem vendidos quaisquer tipos de moeda de ouro, fossem nacionais ou estrangeiras. Ato proibitivo que também foi criado para a obtenção de moedas estrangeiras. Elas envolveram a imposição de um controle sobre a produção industrial, com o reconhecimento dos militares de que o poder que possuíam sobre a capacidade industrial nos territórios ocupados era limitada:

Existem dentro do território submetido à Autoridade da Junta de Defensa Nacional importantes estabelecimentos fabris ou industriais cujos Conselhos de Administração se radicam em cidades que estão em rebeldia armada contra o legítimo Governo da Junta e cujos capitais pertencem em sua quase totalidade aos encarniçados inimigos da Espanha.

Este estado de fato, obriga a ditar as medias de previsão que impeçam que os produtos destas indústrias e as utilidades destas empresas possam se empregar no dano da Pátria. ${ }^{92}$

A decisão adotada foi o controle e a repressão sobre os dirigentes dessas empresas. A partir da formação de um grupo que envolvia os governadores civis das províncias e as representações locais da Fazenda, o diretor do Banco de España, o engenheiro-chefe de

\footnotetext{
91 “Decreto núm. 36" In: Boletin Oficial de La Junta de Defensa Nacional de España. Burgos, 14/08/1936, n. 6, 1936, p. 22-23.

92 “Decreto núm. 37" In: Boletin Oficial de La Junta de Defensa Nacional de España. Burgos, 17/08/1936, n. 7, 1936, p. 25
} 
indústrias, os presidentes das Câmaras Oficiais de Indústria, Comércio e Agricultura, além dos representantes dos bancos privados estabelecidos nas respectivas províncias. Com a estruturação de um órgão repressivo colegiado formado por membros nomeados pela Junta de Defensa Nacional e pela iniciativa privada determinou-se o registro e uma classificação daqueles que colaborariam com os revoltosos. Esse processo teria a seguinte normativa:

(...) se formará uma relação devidamente classificada de todos os estabelecimentos e empresas ou sociedade fabris ou industriais de estimável importância e bancos ou estabelecimentos de crédito que existam na respectiva província, detalhando:

A) Classe das principais operações que realizam, seu montante anual aproximado ou sua produção fabril e industrial e seus mercados principais; o capital imobiliário e o de exploração ou movimento.

B) O nome e domicílio dos Gerentes, Diretores ou Administradores de destes estabelecimentos locais, e em caso que dependam de Conselhos ou Sociedades, o domicílio social dos mesmos e o nome de seus Conselheiros diretivos.

Esta relação deverá ser remetida à Junta de Defensa. ${ }^{93}$

A nova legalidade em relação ao comércio exterior formalizou-se lentamente. Com a instrução $n^{\circ}$ 37, de 28 de setembro de 1936, o General Queipo de Llano estabeleceu a criação da "Junta Reguladora de Exportación y Importación" no território sob seu controle. A ela deveriam ser solicitadas as permissões para importação e exportação, que eram concedidas por meio de um mecanismo de discricionariedade absoluta. Então, a Junta enviava as solicitações a uma "Comisaría de Comercio y Banca", que levaria em conta a totalidade de exportações e importações com a função de fomentar as exportações ou, no mínimo, manter um equilíbrio entre a entrada e a saída de produtos e divisas. ${ }^{94}$

De forma concomitante à constituição das estruturas estatais comandadas pelos rebelados e do controle produtivo e monetário das áreas ocupadas no território espanhol, no campo externo, os generais agiam, como citamos anteriormente, em razão de obter apoio político e militar dos países que poderiam diretamente apoiar suas pretensões contra o governo republicano, ou seja, Alemanha e Itália. Com um avanço inicial que se pautou pela invasão e permanência em regiões predominantemente agrícolas, sem o acesso aos centros industriais mais desenvolvidos da Espanha, alguns dos generais líderes da sublevação e associados às

\footnotetext{
93 “Decreto núm. 37” In: Boletin Oficial de La Junta de Defensa Nacional de España. Burgos, 17/08/1936, n. 7, 1936 , p. 2

94 VIÑAS, Angel et al. Política Comercial Exterior en España (1931-1975). Madrid: Servicios de Estudios Económicos, Banco Exterior de España, 1979, vol. 1, p. 146.
} 
tendências mais conservadoras do Exército - Francisco Franco, Queipo de Llano, Emilio Mola e Miguel Cabanellas Ferrer -, enviaram emissários à Roma e à Berlim.

A partir do alçamento militar desde o Marrocos, se alteraram as relações formais que o Estado espanhol possuía junto à Alemanha nazista durante os primeiros anos republicanos. Os representantes enviados pelos revoltosos foram recebidos diretamente por Hitler e Rudolph Hess que prontamente forneceram o apoio solicitado. Além do suporte prestado pelo Führer, por meio do envio de tropas, materiais bélicos e outros insumos, houve a formação de uma seção especial no Ministério da Guerra alemão, chamado Cos W, para a coordenação das operações na Espanha. Além da logística da intervenção alemã em território espanhol, a nova seção também promoveu a elaboração de uma estratégia para os contatos entre a Alemanha e a Espanha. ${ }^{95}$

Essas estratégicas tiveram como elemento basilar a criação de duas empresas que se transformaram na essência das relações hispano-germânicas e de interferência no conflito intestino espanhol. Para atender os interesses dos rebelados, os primeiros movimentos de ajuda alemã se deram por parte da conexão "Tetuã-Berlim", ou seja, os envios de todo tipo de provisões fariam uma escala no Marrocos espanhol, um dos pontos de partida da sublevação, antes de chegar às mãos dos generais conservadores. Para isso, por um lado, na cidade de Tetuã, capital do Protetorado Espanhol no Marrocos, foi criada em 31 de julho de 1936 uma empresa privada hispano-alemã. Essa empresa agiria sob a razão social de "Carranza y Bernhardt, Sociedad Limitada" e que seria conhecida pelo nome de "Hispano-Marroquí de Transporrte, S.L." (HISMA), controlada exatamente pelos dois emissários que, sob o comando de Franco, haviam solicitado ajuda à Alemanha: Johannes Bernhardt, destacado membro do Partido Nazista e empresário radicado em Tetuãn, e Fernando de Carranza Y Fernandes Reguera, antigo oficial da Marinha espanhola (1876-1950). ${ }^{96}$ Por outro lado, para dar suporte às ações da HISMA foi criada, em 7 de outubro de 1936, por Herman Göring, a "Rohstoff-undWareneinkausfsgesellschaft m.b.G" (ROWAK). ${ }^{97}$

O plano de esquivar-se das determinações da Comissão de Não-Intervenção, não se reduziu somente à criação das duas empresas. Com a complexidade do cenário europeu daquele momento, praticamente toda a condução da política econômica externa da zona

\footnotetext{
${ }^{95}$ CORDERO OLIVERO, Inmaculada y LEMUS, Encarnación, "La internacionalización de la Guerra Civil (19361939)" In: PEREIRA, Juan Carlos (coord.). La política exterior de España (1800-2003): Historia, Condicionantes y Escenarios. 1a. edición. Barcelona: Ariel, 2003, p. 476.

${ }^{96}$ VIÑAS, Angel. La Alemania nazi y el 18 de julio. 2a . edición. Madrid: Alianza Universidad, 1977, p. 386

97 VIÑAS, Angel et al. Política Comercial Exterior en España (1931-1975). Madrid: Servicios de Estudios Económicos, Banco Exterior de España, 1979, vol. 1, p. 147.
} 
nacionalista ficou, a partir de princípios de outubro de 1936, nas mãos das empresas HISMA/ROWAK. A indissociabilidade das empresas possuía motivo bastante claro: a criação de um sistema de caixa de compensação, que permitia aos rebelados evitar a saída das poucas divisas que possuía e aos alemães impedia que os rastros de sua ajuda fossem facilmente descobertos. Ademais, dava vazão a uma das poucas formas que os rebelados tinham de comercializar com o exterior, ou seja, por meio do fornecimento de matérias primas, fossem vegetais ou minerais.

Embora o aparato HISMA/ROWAK tenha servido de ponto de partida quase imediato para sustentar os rebelados, o caminho percorrido pelos nacionalistas para a construção de um organismo político-econômico que viesse a enfrentar a Segunda República não se restringiu somente às duas empresas associadas à Alemanha nazista, mas a uma condição dependente em relação aos germânicos, que conseguiram privilégios na obtenção de produtos primários.

Enquanto os acordos com os nazistas deitavam raízes, a ajuda fornecida pela Itália se apresentou de forma mais objetiva: o fornecimento de soldados e armas. Com uma aproximação política entre conservadores espanhóis e o governo de Mussolini que havia começado, ainda no decorrer do biênio conservador de 1933 e 1935, o fornecimento de armas se apresentou prontamente. As informações expostas pelo consulado norte-americano em Sevilha afirmavam que:

Seguinte material de guerra chegou a Sevilha em 9 de agosto: dez novos bombardeiros Savoia, tri-motores, com cerca de vinte pilotos, dezoito bombardeiros Junker, trimotores, a maioria novos, com cerca de trinta pilotos alemães, duas unidades de tipo similar chegaram depois seis aviões alemães de reconhecimento capazes de quatrocentos e cinquenta quilômetros e seus baterias antiaéreas de último modelo com efetivo alcance de sete mil metros. ${ }^{98}$

No caso português, a sua condição fronteiriça com o Estado espanhol permitiu que o apoio militar fosse mais rápido, além do fato de que Portugal havia dado asilo a militares antes do início da Guerra Civil, como foi o caso de Sanjurjo. Ainda que de forma velada, um dos elementos que se mostrou capital para os militares foi o apoio de Francisco Salazar. Huelva, localizada nas proximidades da fronteira hispano-portuguesa, foi um dos principais focos da rebelião dos militares. Com a base militar ali sediada e comandada por Queipo de Llano sofreu ainda uma débil tentativa de ter o seu levante estancado. No entanto, após o pedido do governo

\footnotetext{
98 “Telegram from Consulate in Seville (Charles A. Bay) to Department of State. Strictly Confidential. August 12 ,
} 1936." General Correspondence of the Department of State. NARA/II. 
de Madrid para que o General fosse preso, o Governador ao ligar para a base, recebeu como resposta que era tarde demais para obedecer tais ordens, ou seja, o Golpe já estava em movimento: ${ }^{99}$

Na manhã de 18 de julho, o General Gonzalo Queipo de Llano, um inspetor de Carabineros atuando diretamente sob as ordens do General Franco, esteve em Huelva. O propósito da sua visita, como explicada para o Governador da Província, era receber na fronteira espanhola, das mãos de certas autoridades portuguesas, certas bandeiras de significância regimental. ${ }^{100}$

A segunda fase abrange desde novembro de 1936 até agosto de 1937. Do ponto de vista do comércio exterior, o bando nacionalista teve a ampla disponibilidade de produtos primários, que foi a base do esforço de manutenção do conflito. Assim, havia dois condicionantes relacionados ao comércio exterior nesse período: a necessidade de manter a fluidez da entrada de materiais de guerra e da entrada de produtos energéticos e industriais para as Forças Armadas, bem como para a população civil, já que não seria possível desenvolver uma base industrial em um período de tempo tão curto e que atendesse as necessidades no decorrer do conflito. E, como ainda não dispunha de reservas de ouro ou outras divisas para suas transações internacionais, era necessário obter cada vez mais produtos primários para a auto-sustentação da rebelião.

Dessa forma, torna-se clara a estratégia de dirigir as ações militares para as regiões mineradoras e industriais no Norte. Ángel Viñas considerava este avanço como "recuperação parcial" das premissas de controle econômico de um Estado. ${ }^{101}$ Os triunfos com a queda da frente republicana asturiana provocaram a ampliação da base produtiva e de uma maior diversificação de correntes exportadoras próprias.

A terceira fase é aquela que corresponde aos triunfos da zona nacional com a queda da frente asturiana. A conquista das regiões ao Norte da Península provocou tanto uma substancial entrada para a ampliação da base produtiva, como também uma maior diversificação das correntes de exportações próprias e uma intensificação do comércio exterior, ainda que não se salvasse de forma definitiva do estrangulamento externo. Esse período foi pautado pela continuidade das precárias relações comerciais com o exterior, com exceção daquelas travadas

\footnotetext{
99 "From Consulate in Seville (Charles A. Bay) to the Department of State. Military uprising in Seville and vicinity. Confidential. August 26, 1936." General Correspondence of the Department of State. NARA/II.

100 "From Consulate in Seville (Charles A. Bay) to the Department of State. Military uprising in Seville and vicinity. Confidential. August 26, 1936." General Correspondence of the Department of State. NARA/II.

101 VIÑAS, Angel et al. Política Comercial Exterior en España (1931-1975). Madrid: Servicios de Estudios Económicos, Banco Exterior de España, 1979, vol. 1, p. 143.
} 
com a Alemanha, a Itália e a Inglaterra, ainda que a emergência de discursos nacionalizantes e autárquicos do novo regime fosse de encontro com o funcionamento dos mecanismos comerciais impostos pelo Terceiro Reich. ${ }^{102}$

No decorrer das duas fases finais, ou seja, a maior parcela de tempo transcorrido sob o conflito interno espanhol, as alterações nas condições específicas não foram tão profundas quanto nos primeiros meses de guerra. $\mathrm{O}$ impacto provocado pelas conquistas militares no período das Juntas e mesmo, a partir de fevereiro de 1938, com o primeiro governo de Franco, não proporcionou alterações drásticas no campo econômico e no fornecimento militar dos três principais parceiros dos sublevados: Alemanha, Itália e Portugal.

É possível perceber que se não houve uma modificação drástica das estruturas que se consolidavam no campo sublevado conforme se alterava a ocupação do território, por outro lado ocorreu um aprofundamento na dinâmica de fluxos externos. No campo político esse processo teve a sua consolidação em 1938, mas no campo econômico a ampliação da chegada de insumos externos no formato de mercadorias, armas e capitais já possuíra um acréscimo e estabilidade a partir do reconhecimento dos sublevados como representantes "legítimos" do Estado espanhol, em novembro de 1936 (Alemanha e Itália) e abril de 1938 (Portugal) ${ }^{103}$

Com a sublevação iniciada, os contatos exteriores se transformaram em um dos pilares da Guerra Civil Espanhola. Nos primeiros momentos após o 17 de julho houve o apoio imediato da Itália, Alemanha e Portugal junto ao rebelados. Quanto ao governo republicano, podemos dizer que ele não teve a mesma sorte. Com as dificuldades encontradas por cenários internos de outros países, ou mesmo perante as políticas continentais de Apaziguamento, além da associação da Frente Popular com a uma pretensa ameaça de sovietização da Espanha, fizeram com que os republicanos ficassem mais isolados. Após o fracasso do apoio da Front Populaire

\footnotetext{
102 VIÑAS, Angel et al. Política Comercial Exterior en España (1931-1975). Madrid: Servicios de Estudios Económicos, Banco Exterior de España, 1979, vol. 1, p. 143.

$103 \mathrm{O}$ reconhecimento de jure do governo português ocorreu de forma tardiamente (28 de abril de 1938) se for levado em consideração o apoio institucional fornecido nos primeiros momentos do conflito espanhol. No entanto, existe um debate na historiografia sobre o momento do reconhecimento de facto que poderia ser considerado desde setembro de 1936 com reclamações de Salazar à Junta Técnica sobre incursões no território português ou quando o cônsul geral de Portugal se instala em Salamanca perante a Secretaria de Relações Exteriores (junho de 1937). Juan Carlos Jiménez Redondo entende como marco de reconhecimento a assinatura do Acordo Provisório de Regulação do Comércio luso-espanhol, em 15 de maio de 1937. Cf. JIMÉNEZ REDONDO, Juan Carlos. "La política del bloque ibérico: las relaciones hispano-portuguesas (1936-1949). Mélanges de la Casa de Velázques (MCV), 1993, t. XXIX (3), p. 181. E, além das considerações de Jiménez Redondo, pode se discutir se o caráter dos iniciais auxílios militar e político, em julho e agosto de 1936, e a facilitação de deslocamentos internos e externos de conservadores asilados em território português, não poderiam ser considerados como o reconhecimento ou pré-reconhecimento.
} 
francesa, o seu apoio financeiro ficou essencialmente nas mãos de Moscou e militarmente com a contribuição das Brigadas Internacionais.

Enquanto o crescente conflito espanhol se tornou o foco imediato europeu, os seus efeitos atravessaram o Atlântico, encontrando o continente americano e os cenários dos Estados Unidos e do Brasil

No caso estadunidense, o conflito atingiu diretamente o seu conjunto de exportações que necessitavam da maior quantidade possível de mercados, afinal era ainda a frágil a recuperação econômica do entreguerras. E, concomitantemente, se aprofundavam os debates sobre a política externa e suas tendências internacionalistas e isolacionistas.

A situação do Brasil, similar ao espanhol na seara internacional, não impactava na condução do conflito. O papel inicial do governo brasileiro frente à Guerra Civil Espanhola vinculava-se diretamente às suas políticas domésticas e os conflitos existentes entre a esquerda e a direita. Dessa forma, as atitudes que surgiram dos debates institucionais internos e de um primeiro apoio velado aos rebelados, se coadunam com a própria dinâmica da política externa brasileira no período.

\subsection{Os diplomatas contra a República: o surgimento da representação sublevada}

Com o início do conflito espanhol, uma precoce manifestação de lealdade dos diplomatas de carreira junto aos nacionalistas, ainda que não soubessem qual era a tendência ideológica hegemônica ou mesmo suas reais chances de triunfo ocorreram de forma acelerada no exterior. Esse movimento de apoio e principalmente de deserção do corpo diplomático vinculado ao governo de Madri sustentava-se na característica de uma camada burocrática vinculada ao tradicionalismo da elite espanhola, que se chocava diretamente com as propostas da Frente Popular e com os atos relacionados com o início do regime republicano. Ademais, causou descontentamento a intenção do então Ministro Augusto Barcia de requerer às Cortes, uma reforma no modo de seleção e formação do corpo diplomático republicano.

Logo após a proclamação de 14 de abril de 1931, a renovação dos quadros políticos espanhóis com a Segunda República também afetou a organização burocrática da diplomacia espanhola. O desconforto dos membros do então corpo diplomático teve seu início com a tendência de nomear pessoas que não faziam parte da carreira para prover rapidamente os cargos daqueles que se demitiram no início do novo governo. Uma circunstância que inicialmente se apresentou como temporária, a partir de 1932 aprofundou-se com aposentadoria compulsória de membros da velha guarda ministerial que haviam apoiado o Pronunciamento do General Sanjurjo. 
Dessa forma, se por um lado, essas nomeações foram consideradas essenciais para a manutenção do serviço exterior, para a construção de um corpo leal ao novo regime e prestigiar as relações externas espanholas como uma clara demonstração de superação das características do velho regime monárquico; por outra, a proposta de nomeação intelectuais vinculados a posicionamentos mais progressistas do que da elite tradicional ${ }^{104}$ para o corpo diplomático espanhol, foi tomado como uma intromissão e que provocava cisões internas que iam do campo ideológico aos processos de promoção de carreira.

Com o fim do primeiro biênio republicano e a retomada do controle do estado Estado por parte dos conservadores, o cenário de modificação da diplomacia espanhola se paralisou e houve um retorno às condições pré-republicanas. A partir de 1934, com a formação de um novo gabinete de talhe conservador e o retorno ao poder de uma parcela dos antigos partidários de Alfonso XIII, as diretrizes diplomáticas da Espanha distanciaram-se dos Estados mais liberais e social-democratas e iniciaram contatos mais próximos junto às potências conservadoras europeias: a Itália e a Alemanha.

No entanto, foi feita uma proposta de reforma da carreira e das regras do corpo diplomático do Estado espanhol, em junho de 1936, pelo Ministro Augusto Barcia Telles. Ela consistia na unificação da carreira consular e diplomática e criava a possibilidade de participação por meios técnicos e facultativos, que atingiria tanto os membros mais antigos, como aqueles que haviam ingressado durante a Segunda República, além de atender aos interesses políticos imediatistas. Com as regras estabelecidas, os cargos de embaixador e de ministro plenipotenciário de $1^{\mathrm{a}}$ classe podiam ser conferidos tanto àqueles de carreira bem como às pessoas de reconhecido prestígio que fossem de formação diplomática. E, os cargos de ministro de $2^{\mathrm{a}}$ e $3^{\mathrm{a}}$ classes e os secretários de embaixada de $1^{\mathrm{a}}, 2^{\mathrm{a}}$ e $3^{\mathrm{a}}$ classes seriam compostos obrigatoriamente por funcionários de carreira, com a promoção sendo executada pela ordem de antiguidade. ${ }^{105}$ Entretanto, mesmo antes da implantação das novas regras, a reforma acabou por ser abortada pelo levante militar de julho.

Os primeiros efeitos do Golpe de 17 de julho foram sentidos rapidamente nas esferas diplomáticas espanholas. A simples possibilidade de um movimento que representara a volta da "lei" frente à "anarquia" da Frente Popular, foi o suficiente para o elitista corpo diplomático espanhol apoiar aos rebeldes em busca do retorno aos moldes tradicionais, com a manutenção da velha hierarquia e das crenças perdidas com a hegemonia das frações mais progressistas da

\footnotetext{
${ }^{104}$ TABANERA GARCIA, Nuria. "Los orígenes de la diplomacia franquista en America Latina. " In: El Régimen de Franco (1936-1975). Actas del Congreso Internacional. Madrid, Mayo 1993, t. II, p. 507.

${ }^{105}$ Ibidem.
} 
Segunda República. O rápido apoio aos rebelados, que levou a uma adesão de $84,5 \%$ da totalidade dos membros do Ministerio de Asuntos Exteriores, provocou um rompimento dos trabalhos em Madri e a paralisação no serviço exterior.

Com a vinculação de antigos membros do corpo diplomático republicano junto à administração militar, que se formava na cidade de Burgos, apontou-se no horizonte um caminho do corte das vias de comunicação entre espanhóis no estrangeiro com o governo republicano em Madri. Com isso, embora por um lado as lideranças dos rebelados ainda possuíssem um certo caráter policêntrico na Península, já se tornava claro que havia um determinado grupo de diplomatas que estabeleciam um corpo coeso contra o governo republicano. Os efeitos do conflito tomaram um caráter dentro da sociedade que ultrapassou as fronteiras espanholas e europeias, com significativo impacto nas áreas com um grande contingente de imigrantes, como era o caso da América Latina. Efeito provocado tanto nas representações diplomáticas, como na própria população espanhola vivente na região.

Enquanto os republicanos intentavam recompor o serviço diplomático e defender, junto aos governos locais, a legalidade do Estado e da Frente Popular e dessa forma representar e executar os direitos diplomáticos e consulares que lhe correspondiam, começou a tomar corpo as representações Nacionais, que de forma célere tentavam criar uma estrutura de política externa que englobasse tanto o corpo diplomático, como o estabelecimento de uma infraestrutura para as suas ações. Para tanto, a América Latina foi uma das primeiras áreas em que se tentou consolidar o projeto "Espanha Nacional". 106

E, finalmente, os rompimentos que se deram no interior das comunidades de espanhóis na América ibérica, entre aqueles que eram a favor da república ou dos sublevados. $\mathrm{O}$ posicionamento dos primeiros envolvia, principalmente, parte dos imigrantes intelectualizados e aqueles ligados aos movimentos sociais e sindicais. Enquanto que aqueles que eram a favor dos sublevados situavam-se principalmente entre os espanhóis que possuíam interesses econômicos e que possuíam penetração e influência política em alguns Estados latinoamericanos, invocando o papel de combate ao comunismo.

As representações espanholas, da embaixada no Rio de Janeiro aos consulados em outras cidades, também se fragmentaram de forma acelerada. Em um mesmo gradiente de divisão que atingiu o continente, os diplomatas fiéis ao governo republicano entraram na espiral de tentativa de apoio externo contra os sublevados, enquanto que os diplomatas sublevados apresentaram uma ofensiva para anular a política externa republicana junto ao Brasil para serem

${ }^{106}$ CERVANTES, Ángel; PEREIRA, Juan Carlos. op. cit., 1992, 45. 
reconhecidos como os representantes do Estado espanhol em território brasileiro. De acordo com um dos primeiros espanhóis a se apresentar como sublevado, assim se distribuía as representações espanholas:

Espanha vem sustentando no Brasil uma Embaixada (1 Chefe, 2 Secretários; 1 Canciller $^{107}$ ), um Consulado Geral em São Paulo (1 Cônsul Geral, o ViceCônsul de carreira e o Oficial de Chancelaria) e os consulados de carreira de Rio, Santos, Porto Alegre, Bahia e Pernambuco (1 Cônsul efetivo em cada consulado e 1 oficial de chancelaria). E mais de 40 Vice-Cônsules honorários. ${ }^{108}$

Em um dos primeiros posicionamentos a respeito dos efeitos da sublevação em território brasileiro, imputava-se que o governo Vargas tendia claramente para o anticomunismo, devido principalmente aos eventos que ocorreram no ano anterior. Assim, o representante dos militares rebelados enxerga como propício o momento para uma aproximação junto ao governo:

A opinião pública é mais que favorável a nosso lado. O governo brasileiro também vê a causa com simpatia. A colônia espanhola em sua imensa maioria está a nosso lado. E os que não estão deverão se recolher pois a polícia já há detido a alguns por se expressar com veemência a favor dos espanhóis marxistas. ${ }^{109}$

E, em um primeiro momento, pensa que quaisquer tentativas de estabelecer o reconhecimento dos facciosos como governo legítimo está em uma condição muito mais fácil do que aparenta.

\begin{abstract}
A beligerância teria que ser pedida por circular de maneira simultânea a todos os governos amigos; naturalmente que cabe a um governo concedê-la, já o sei de forma direta, mas resultaria em posição de franca hostilidade desde esse momento o governo que agora é só de Madrid e antes era de Espanha. A concessão sairia imediata, como já telegrafei a V.E., pois o Brasil está claramente ao lado da causa; ${ }^{110}$
\end{abstract}

\footnotetext{
107 A função de Canciller, relacionado à função de auxiliar de embaixadas, legações, consulados e agências diplomáticas e consulares será traduzida, doravante, como oficial de chancelaria.

108 "Número 09". De Julián Chacel ao General Presidente da Junta de Defesa Nacional (General Miguel Cabanellas) em Burgos. 31/08/1936. AMAE, R/1001(3).

${ }^{109}$ De Julián Chacel ao General Presidente da Junta de Defesa Nacional (General Miguel Cabanellas) em Burgos. n. 3. 12/08/1936. AMAE, R/1001(3).

${ }^{110}$ Ibidem.
} 
Em contato direto com a Junta de Defensa Nacional, Julián Chacel esclarecia que ao fim de agosto de 1936 Teodomorio Aguilar (embaixador) e os cônsules de São Paulo (José Maria Sempere y Olivares) e Porto Alegre (Fulgencio Vidal y Saura) estavam a favor do governo republicano e mantinham seus cargos pré-sublevação. Aqueles que haviam se demitido, mas que haviam aderido à Madri, constavam José de Carcer y Lassance $\left(1^{\circ}\right.$ Secretário), Luis Viñals y Fons ( $2^{\circ}$ Secretário) e o Cônsul Eduardo Danís, lotado no Rio de Janeiro. ${ }^{111}$ Destaca-se na comunicação de Chacel, a observação do paradeiro do $1^{\circ}$ Secretário da embaixada que teria voltado à Europa para se apresentar à Junta de Defensa Nacional e reportar a sua situação e dos outros dois demitidos. No entanto, aparenta que o remetente sabia ou imaginava das intenções de Cárcer e seus companheiros em assumir a representação sublevada no Brasil e sugeria a falta de compromisso do trio:

Destes três senhores não tenho informação alguma de que tenham realizado qualquer trabalho prático para defender e apoiar os interesses da nossa causa. ${ }^{12}$

Não tardou para que uma resolução viesse desde a Junta. E que as tentativas de desqualificar os dois secretários e o Cônsul Danís foram infrutíferas. Um telegrama enviado pelo próprio General Cabanellas a Viñals os apresentava como o núcleo inicial e de confiança dos sublevados para constituir a representação sublevada:

Telegrafado ontem Chacel insisto conteúdo do telegrama encarregando formem todos únicos Junta única. Díga-lo Chacel. CABANELLAS ${ }^{113}$

A comunicação de Miguel Cabanellas residiu claramente a partir da intervenção de José de Cárcer y Lassance para que os três ex-diplomatas republicanos assumissem o comando em território brasileiro junto de outros simpatizantes do golpe em curso na Espanha.

A Junta Oficial tomou a seu cargo o trabalho de ampliar, coordenar e disciplinar todo o movimento no Brasil pró-Junta de Defesa Nacional de

\footnotetext{
111 Conforme os documentos 923.1 (8h).(h2) e 923.2 (8h).(h2) arquivados no AHI, em 31 de julho de 1936, a embaixada espanhola, sob controle republicano, enviou duas notas que comunicavam ao MRE o desligamento desses diplomatas.

112 “Número 09”. De Julián Chacel (Rio de Janeiro) ao General Presidente da Junta de Defesa Nacional (General Miguel Cabanellas) em Burgos. 31/08/1936. AMAE, R/1001(3).

113 “Telegrama Oficial” De Miguel Cabanellas (Burgos) a Eduardo Viñals (Rio de Janeiro). 08/09/1936. AGA
} 
Burgos controlando todas as atividades que se relacionem com o movimento libertador da Espanha nesse país. ${ }^{114}$

O impulso inicial de Chacel - que era oficial do exército e, segundo o próprio, estava de férias no Rio de Janeiro quando houve a sublevação -, de concentrar em si as ações da constituída Junta Oficial Nacionalista Española en el Brasil e ignorar as instruções dos sublevados foi atacada de forma aguda. E que ele seria um ponto de fragmentação nas relações com os membros da colônia espanhola que apoiavam os insurgentes:

(...) começou certa divergência e rivalidade, às vezes por mínimos detalhes, que graças aos constantes esforços meus e de Danis conseguimos apaziguar. Não queriam admitir nenhuma indicação que procedesse de Chacel, pois não conta com nenhuma simpatia. Pouco a pouco as coisas vão se encaminhando e procuramos contentar a todos para evitar males maiores e evitar nesses momentos a divisão da colônia, que seria de lamentar e produziria péssima impressão. ${ }^{115}$

Os conflitos narrados por Viñals envolviam a formação inicial sublevada no Brasil que havia sido intitulada como Comisión Nacionalista Española, que havia sido criada pelo próprio Julián Chacel e que envolvia uma grande quantidade de espanhóis residentes no Rio de Janeiro:

Depois de vencer algumas dificuldades pelo seu caráter reservado, organizamos uma Comissão, sob o nome de Comissão Nacionalista Espanhola do Rio de Janeiro, para se encarregar da propaganda e da remessa de fundos. ${ }^{116}$

No entanto, no momento da elaboração de tal Comisión, Chacel havia convidado outros elementos que, segundo o antigo segundo secretário, não teria influência para angariar apoio à "Causa". A estratégia teria sido de apenas conseguir maioria nas votações para que se pudesse controlar o direcionamento do Movimiento em terras brasileiras:

Desta forma, a Junta, podes imaginar, que a nossa influência dentro da mesma quase nula, pois tudo se resolve por maioria y Chacel conta com sete votos em qualquer assunto e ocasião. Dita Junta interpretando fielmente o telegrama de Burgos deveria estar formada por Chacel, Danis, eu, e os cinco senhores que formam a Comissão de arrecadação, mas Chacel antepôs sua ambição e ânsia de domínio às convinências do momento. ${ }^{117}$

\footnotetext{
${ }^{114}$ Do Segundo Secretário Luis de Viñals y de Fons da Embaixada no Rio de Janeiro ao General Presidente da Junta de Defesa Nacional (General Miguel Cabanellas) em Burgos. 30/09/1936. AMAE

${ }^{115}$ Carta de Eduardo Viñas (Rio de Janeiro) a José de Carcer y Lassance (Burgos). 03/09/1936. AGA

${ }^{116}$ De Julián Chacel ao General Presidente da Junta de Defesa Nacional (General Miguel Cabanellas) em Burgos. n. 13. 01/09/1936. AMAE

${ }^{117}$ Carta de Luis Viñals y Fons (Rio de Janeiro) a José de Carcer y Lassance (Burgos). 03/09/1936. AGA
} 
Em contínua correspondência com o General Cabanellas, enquanto também da presença de Cárcer em Burgos, Viñals comunicou que o núcleo "duro" da Junta Nacionalista brasileira, responsável pela propaganda e aproximação junto às autoridades nacionais, estava composto por antigos diplomatas do governo republicano. Dentro do panorama daqueles que ficaram a favor do governo republicano e os outros que foram ao encontro dos sublevados, percebe-se que estes últimos estavam compostos dos funcionários de carreira do Ministério de Asuntos Exteriores.

No consulado espanhol em Porto Alegre, os processos de deserção e fragmentação do pessoal que trabalhava na repartição tomou um corpo mais sólido em fins de setembro de 1936, quando o oficial de chancelaria, Álvaro Raya Ibañez, adotou as diretrizes da Junta Oficial Nacionalista Española. Ao retornar e assumir o controle do consulado, a partir de 15 de outubro, afirmou que,

(...) me encarreguei interinamente deste Consulado e desde então mantive esta Representação a serviço do Governo do Estado Espanhol. Não cumpri, antes dessa data, nenhuma missão política que pudesse favorecer ao mal-chamado Governo de Madri, ao qual não prestei adesão. Uma prova dessa confirmação é o fato de não ter acolhido nenhum oferecimento de voluntários para as milícias vermelhas, apesar de ter recebido, então, alguns pedidos não só de espanhóis, mas de estrangeiros, estes em maior número. ${ }^{118}$

Com a mesma amplitude de interesses que os militares atendiam no interior da Espanha, surgiu uma miríade de posicionamentos e grupos que tomavam para si, no interior das comunidades imigrantes espanholas, o protagonismo dos interesses da administração nacionalista no exterior. Para que se evitasse esse tipo de competição e que era leal aos revoltosos, Raya Ibañez solicitou algum tipo de credencial que pudesse ligá-lo ao incipiente Governo de Burgos.

(...) agora me movimento e aonde alguma vez tropeço com a desconfiança de alguns núcleos nacionalistas que creem dúbia minha atitude ao continuar à frente do Consulado que por certo é mantido para defender os interesses de um Governo que não reconheço, que não me paga salário nem paga o aluguel do Consulado, mas para por este mesmo Consulado à serviço do legítimo Governo do Estado Espanhol, a Junta de Defensa Nacional, não descuidando ao mesmo tempo a defesa dos interesses espanhóis nesta demarcação. ${ }^{19}$

\footnotetext{
118 Oficio el Canciller encargado del Consulado español en Porto Alegre, Álvaro Raya Ibañez, al Secretario de Relaciones Exteriores del Gobierno de Burgos. Oficio n. 10, 8 de diciembre de 1936. AMAE

${ }^{119}$ Ibidem.
} 
Os embaixadores e principais cônsules eram os homens de confiança da Segunda República, os diplomatas em graus de segundo escalão ou outros funcionários, como era o caso de oficiais de chancelaria, se tornaram os principais aríetes para o avanço insurgente no Brasil. Dessa forma, os problemas que haviam emergido em 1931 com a tentativa de renovação dos quadros diplomáticos tomaram vulto com o levante de julho de 1936 e a participação incisiva de funcionários aliados e pertencentes, ideologicamente, aos conservadores e militares espanhóis. Em 9 de setembro houve a criação formal de jure da Junta Oficial Nacionalista en el Brasil, embora já estivesse em ação desde meados de agosto:

A Junta Oficial assumiu o trabalho de ampliar, coordenar e disciplinar todo o movimento no Brasil pro-Junta de Defensa Nacional de Burgos controlando todas as atividades que se relacionem com o movimento libertador da Espanha neste país. ${ }^{120}$

Além da criação da Junta, com sede no Rio de Janeiro, também foi determinada a criação de delegados em todos os Estados brasileiros. No caso específico do Estado de São Paulo, foram nomeados como delegados locais Miguel Cordomi (Vice-Cônsul em São Paulo), Fernando Navarro (Cônsul em Santos) e José Ozores, que era Presidente da Câmara de Comércio de São Paulo. ${ }^{121}$ Abaixo, a composição total de seus fundadores conforme se apresenta na Ata de constituição:

\footnotetext{
${ }^{120}$ Carta de Luis Viñals y Fons (Rio de Janeiro) ao General Presidente da Junta de Defesa Nacional (Miguel Cabanellas) em Burgos. 30/09/1936. AGA

${ }^{121}$ Ibidem.
} 


\begin{tabular}{|l|l|}
\hline \multicolumn{2}{|c|}{ 1.5 Junta Oficial Nacionalista Española en el Brasil } \\
\hline Don Julián Chacel & Comandante de Estado-Maior (aposentado) \\
\hline Don Francisco Ignacio Areal & Comerciante \\
\hline Don José Pellicer Ramos & Comerciante \\
\hline Dr. Luis Hontán de Yparraguirre & Advogado e industrial \\
\hline Don José Bernardes & Comerciante \\
\hline Don José Vicente Velo & Comerciante \\
\hline Don A. Gasca & Comerciante \\
\hline Don Camilo F. Garrido & Comerciante \\
\hline Don Eduardo Danis y Navarro & Cônsul da Espanha no Rio de Janeiro \\
\hline Don Luis de Viñals y de Fons & Secretário da Embaixada no Rio de Janeiro \\
\hline \multicolumn{1}{|c|}{ Delegados nomeados da J.O.N.E.E.B } \\
\hline Estado de São Paulo & Fernando Navarro Jordán - Cônsul de Santos \\
\hline Cidade de São Paulo & Miguel Cordomí - Vice-Cônsul em São Paulo \\
\hline Cidade de Santos & José Ozores - Pres. Camara de Comercio Española de San Pablo \\
\hline Rio Grande do Sul & Juan Llopart - Vice-Cônsul da España \\
\hline Bahia & José Cortizo Bouzas - Comerciante \\
\hline Recife (Pernambuco) & Luiz Perez - Comerciante e ex-Vice-Cônsul \\
\hline Fonte: ACTA DE LA CONSTITUCION DE LA “Junta Oficial Nacionalista Española en el Brasil” AGA
\end{tabular}

Fonte: ACTA DE LA CONSTITUCION DE LA “Junta Oficial Nacionalista Española en el Brasil” AGA

Em relação à situação de Chacel, os líderes da Junta Nacionalista encontraram uma forma para que houvesse sua participação, mas sem ter o protagonismo ou ligações diretas com Burgos. ${ }^{122}$ Foram criadas funções distintas para a Junta e para Comisión Nacionalista:

(...) para a "Junta Oficial" centralizar e ampliar por todo o Brasil o apoio e adesão dos espanhóis e estrangeiros à nobre causa que o Governo de Burgos dirige da salvação de Espanha, e para a "Comisión Nacionalista", fomentar o apoio material e moral do apoio no Rio de Janeiro, canalizando a ela as arrecadações pequenas de alguns pontos do interior do país. ${ }^{123}$

\footnotetext{
${ }^{122}$ Entre novembro e dezembro houve aprofundadas discussões entre Julián Chacel e José de Cárcer sobre o controle da Junta Nacionalista Española en Brasil. Embora alguns elementos da disputa envolvam, ainda que de forma lateral, temas desta pesquisa, decidimos excluir tais disputas da discussão sobre a Junta. E que ao final foi retirado do comando. Em momento futuro a documentação a respeito das escaramuças entre ambos e que foi localizada no Archivo General de la Administración, em Alcalá de Henares, será objeto de uma abordagem mais profunda.

${ }^{123}$ Carta de Luis Viñals y Fons (Rio de Janeiro) ao General Presidente da Junta de Defesa Nacional (Miguel Cabanellas) em Burgos. 30/09/1936. AGA
} 
Como expõe Souza, ${ }^{124}$ em 9 novembro de 1936, Cárcer y Lassance apresentou Carta Credencial ao Itamaraty e que consta arquivada nos fundos documentais do Itamaraty. Enquanto a autora sugere que haveria uma postura dúbia do Ministério de Relações Exteriores, para nós, a trajetória que a representação sublevada possuiu durante o governo Vargas mostrou que a proximidade era muito maior que simples "jogo-duplo". Com o cargo de Encarregado de Negócios do Governo do Estado Espanhol, essa aproximação junto ao governo brasileiro, por meio do Itamaraty, tem destaque em dezembro de 1936, com a conversa entre ele e o ministro Pimentel Brandão, que já coloca condições para o reconhecimento do novo regime comandado pelos militares:

(...) fui recebido pelo Ministro Interino de Relações Exteriores Senhor Pimentel Brandão, a quem já me une uma antiga amizade.

(...) me disse espontaneamente que o Governo brasileiro estava disposto a reconhecer o nosso, conquanto fossemos os donos de Madri, não o fazendo antes por temor de possíveis represálias, não somente contra o seu Embaixador, mas também contra os refugiados políticos que se encontram na Embaixada do Brasil (...). ${ }^{125}$

Enquanto que no campo político houve o processo de organização da Junta Nacionalista, ações de arrecadação e de manutenção financeira do órgão sublevado foram organizadas entre outubro e dezembro de 1936. A estratégia utilizada pela Junta no Brasil foi de enviar para as representações dos militares para outros países europeus. Duas remessas foram realizadas para Lisboa e Paris, destinadas respectivamente à Junta de Representación Española e a José María Quiñones León, antigo embaixador de Alfonso XIII na capital francesa e que seria um dos principais articuladores contra as ações políticas do governo republicano na França:

As remessas de fundos até agora efetuadas foram as seguintes: DEZ MIL francos franceses ao Exmo. Sr. D. José Quiñones de León em Paris e um total de Oitenta e um mil escudos portugueses a Lisboa, como tive a honra de comunicar a V. Exa. em telegrama de 21 de setembro e cartas de 7 e 21 de outubro passado. ${ }^{126}$

\footnotetext{
${ }^{124}$ Cf. SOUZA, Ismara Izepe de. op. cit., p. 67.

125 “Informa acerca visita Ministro Relações Exteriores do Brasil.” Do Representante do Estado Nacional Espanhol no Rio de Janeiro (José de Carcer) ao Secretario de Relaciones Exteriores do Governo do Estado Espanhol (Francisco Serrat y Bonastre) em Burgos. n. 3. 15/12/1936.” AMAE

${ }^{126}$ Carta de Miguel Cordomí (São Paulo) ao Secretário de Estado. Gobierno Nacional de Burgos. 04/11/1936. AGA.
} 
O ano de 1937 se iniciou com os sublevados se reportando a Burgos sobre as condições da política interna brasileira. ${ }^{127} \mathrm{O}$ conteúdo da missiva expõe a renúncia do então governador de São Paulo, Armando Salles de Oliveira, para poder concorrer às eleições presidenciais de 1938, além da saída de Vicente Rao, do Ministério de Justiça, e de José Carlos Macedo Soares, do Itamaraty. E que as instabilidades poderiam trazer um cenário de movimentação militar ainda para o ano de 1937:

Dado que falta mais de um ano para as eleições gerais, a situação política sofrerá profundas e constantes modificações, não sendo de estranhar que os mais pessimistas vejam em tudo isso a possibilidade de transtornos graves que obriguem a intervenção das forças armadas. ${ }^{128}$

Na esfera pública, as ações dos sublevados no Rio de Janeiro se concentraram na divulgação dos programas políticos conservadores e nas aproximações junto ao governo brasileiro pelo reconhecimento de beligerância. Os eventos se tornaram uma constante no Rio de Janeiro e voltavam-se principalmente para os membros da colônia espanhola que não haviam se associado àqueles que promoviam um rompimento com a Segunda República Espanhola. Um desses eventos mais divulgados e que apresentava força foi aquele anunciado para ocorrer no Instituto Nacional de Música no dia $1^{\circ}$ de junho de 1937, por Cárcer y Lassance. Inclusive com apelos para que o governo brasileiro interferisse, conforme comunicação do Encarregado de Negócios do governo republicano, José Maria Sempere:

Como dita conferência está anunciada em um local que ostenta caráter oficial, o conferencista se atribuindo de uma representação legal que não possui e pretende abordar assunto de índole política, me permito rogar a V.E., com a urgência possível se assim possível, as ordens oportunas para que o referido ato seja suspenso para evitar possíveis protestos e distúrbios por pessoas que veem com desagrado esta atividade oficiosa por parte de elementos que pretendem semear a discórdia entre a trabalhadora colônia espanhola radicada nesta capital. ${ }^{129}$

Enquanto a claudicante representação republicana agia para impedir as aparições públicas da Junta Nacionalista brasileira, o reconhecimento enquanto Estado ou da condição

\footnotetext{
127 “Informa sobre politica interior y dimisión Ministros Relaciones Exteriores y Justicia”. De José Carcer (Rio de Janeiro) a Francisco Serrat y Bonastre, Secretario de Relaciones Exteriores (Salamanca). 03/01/1937. AGA 128 Ibidem.

${ }^{129}$ Nota de José Maria Sempere (Rio de Janeiro) a Mario de Pimentel Brandão. 01/07/1936. AHI.
} 
de beligerância foi um tema constante dos sublevados, desde a organização inicial, feita por Julián Chacel, à consolidação do órgão por José Cárcer y Lassance.

Para alcançar o reconhecimento por parte do governo brasileiro de alguma espécie de ato que tivesse validade na seara internacional e de forma bilateral, foi inicialmente gestada a proposta de considerar as estruturas estatais dos sublevados como uma entidade autônoma à de Madri. As resoluções e análise sobre a matéria do reconhecimento de Estado e governo, na década de 1930, do ponto de vista do Direito Público Internacional, era àquele tempo, como no tempo presente, de livre arbítrio da parte que deseja reconhecer. ${ }^{130}$ Com os impedimentos que tal reconhecimento tomaria em um âmbito interno, com os grupos políticos internos ou mesmo com a colônia de origem ibérica; e, junto aos Estados Unidos, a quem haviam consultado nas primeiras semanas de combate, e as relações com a Alemanha nazista. Embora os sublevados tenham se enveredado pela estratégia do tema da beligerância.

Entre julho e agosto de 1937, a tática utilizada foi a de consultar as representações diplomáticas localizadas no Rio de Janeiro e que estavam dentro do círculo de polarização e posicionamento internacional da Guerra Civil Espanhola. Após ir ao encontro dos italianos, Cárcer afirmou que:

Em conversa que tive com o Embaixador da Itália essa manhã, ele me disse que acreditava que o Brasil procederia a este reconhecimento independentemente do que fizessem outras nações. Me permito opinar o contrário ao adiantar que, ao meu parecer, não é de se esperar que o Brasil tome uma decisão unilateral neste assunto. ${ }^{131}$

Pelo comentário do embaixador italiano, Vicenzo Lojacono, o governo brasileiro se encontrava alinhado com um posicionamento externo, que claramente era o adotado pelos Estados Unidos. Em consulta ao representante norte-americano, o homem de ligação dos sublevados espanhóis no Brasil recebeu uma ducha de água fria a respeito de suas intenções:

Ontem me encontrei casualmente, em uma recepção, com o Encarregado de Negócios yankee que me disse com toda franqueza que, por hora, seu Governo se mostrava oposto a que o Brasil fizesse algum passo para reconhecer nossa beligerância. ${ }^{132}$

\footnotetext{
${ }^{130}$ Cf. MAZZUOLI, Valerio de Oliveira. Curso de Direito Internacional Público. $7^{\text {a }}$ Edição. São Paulo, Revista dos Tribunais, 2013, p. 435.

131 “Acerca reconocimiento beligerancia". Do Representante do Estado Nacional Espanhol no Rio de Janeiro (José de Carcer) ao Secretario de Relaciones Exteriores do Governo do Estado Espanhol (Burgos). 06/07/1937. AMAE 132 "Acerca reconocimiento nuestra beligerancia". Do Representante do Estado Nacional Espanhol no Rio de Janeiro (José de Carcer) ao Secretario de Relaciones Exteriores do Governo do Estado Espanhol em Salamanca. 03/08/1937." AMAE
} 
A insistência no reconhecimento de beligerância da Junta Técnica del Estado junto ao governo brasileiro voltava-se à possibilidade de que lhe fosse atribuída um caráter incipiente e provisório de Estado e com certos status jurídicos que equivalessem com os plenamente estatais e que teriam efeitos jurídicos imediatos na arena internacional. ${ }^{133}$ Ser reconhecido de facto permitiria que os militares revoltosos pudessem estar em pé de igualdade com o governo de Madri tanto no âmbito político como no econômico. ${ }^{134}$

${ }^{133}$ Cf. MAZZUOLI, Valerio de Oliveira op. cit., p. 436; 484.

${ }^{134}$ As análises pertinentes ao campo do Direito Público Internacional, ainda que atinentes à estratégia dos militares espanhóis rebelados, não serão objeto de maiores desdobramentos nesta pesquisa. A abordagem de doutrinas, que surgiram nas primeiras décadas do século XX e que se voltam à questão do reconhecimento de entidades do Direito Público Internacional, como a Doutrina Estrada e a Doutrina Tobar, não são o escopo desta pesquisa. De forma preliminar, além da obra de Mazzuoli, sugerimos os seguintes trabalhos: ACCIOLY, Hildebrando, NASCIMENTO E SILVA, G. E.; CASELLA, Paulo Borba. Manual de Direito Internacional Público. $20^{\mathrm{a}}$ Edição. São Paulo: Saraiva, 2012. DINH, Nguyen Quoc; DAILLIER, Patrick; PELLET, Alain. Direito Internacional Público. 2 2a Ed. Lisboa: Fundação Calouste Gulbenkian, 2003. 


\section{O Brasil e o cenário inicial: posicionamento e interferências externas (1936-1937)}

\subsection{A pífia trajetória das relações comerciais hispano-brasileiras na Segunda República}

Desde o século XIX, as relações entre Brasil e Espanha nunca foram pautadas por um estreitamento de interesses comerciais. Embora, nunca tenha existido circunstâncias específicas impeditivas, tampouco houve algum tipo de aprofundamento. Alguns autores, como Ayllon Pino $^{135}$ e Perez Herrero ${ }^{136}$, ressaltam, que havia contatos bilaterais apenas por um "eixo sentimental", como diz o primeiro autor, ou que o Brasil não era um país pertencente à região hispano-americana. Esses dois posicionamentos, embora possuam relevância na compreensão das tíbias relações hispano-brasileiras, não podem ser conclusivos para a compreensão dos poucos contatos entre os dois países, pois também envolveram outros atores e não foram uma exceção dentro do contexto ibero-americano.

Na virada do século XIX para o XX, a relação da Espanha com a América Latina pautava-se por meio de um pan-hispanismo ${ }^{137}$, sustentado na exaltação do catolicismo, na hegemonia da língua castelhana, em uma reivindicação do passado colonial como elemento histórico central e a construção de uma ordem social sustentada na hierarquização e no nacionalismo. Os conjuntos de ação relacionados a essa forma de se ver e abordar a América Latina desde o governo do rei Alfonso XIII estavam sob a batuta da Junta de las Relaciones Culturales, que além de apresentar o discurso governamental de submissão da lógica social, política e cultural latino-americana, também eram o centro das relações econômicas com as repúblicas latino-americanas. Em grande medida, prevaleceu entre 1898 e o começo da década de 1920, tênues ligações políticas entre a antiga e decadente metrópole e suas antigas colônias.

$\mathrm{O}$ afastamento da Espanha em suas relações externas frente à América Latina, a ponto de chegar ao total rompimento, centrou-se a partir das consequências das Guerras HispanoAmericanas e suas decorrências. Os conflitos ao final do século XIX envolveram, por um lado, os Estados Unidos em franca expansão política e econômica e, por outro, a Espanha que estava em um diapasão completamente oposto, já que essa vinha paulatinamente sofrendo a perda de importância tanto no continente europeu, como ao redor do globo. E, em meio aos dois países

\footnotetext{
135 AYLLÓN PINO, Bruno op. cit., 2004. O autor considera que a superação dessa condição somente ocorreria a partir do governo de 1995 com o governo de Fernando Henrique Cardoso.

${ }^{136}$ HERRERO, Pedro Pérez. "Las relaciones de España con América Latina durante los siglos XIX y XX: discursos gubernamentales y realidades" In: PEREIRA, Juan Carlos (coord.). La política exterior de España (1800-2003). Barcelona: Editorial Ariel, 2003, p. 332.

137 Ibidem.
} 
houve o fracionamento interno da população das áreas em conflito, que penderam ora para o lado espanhol, ora para o norte-americano.

Os Estados Unidos, desde o fim da Guerra de Secessão (1861-1865), estavam em um crescente processo de expansão: primeiramente, no âmbito territorial interno com a ocupação, colonização e fixação no Oeste da América do Norte; e em segundo lugar, na expansão de seus tentáculos que estabeleceria sua hegemonia política e econômica no Caribe, América Central e no Pacífico. A rápida vitória dos Estados Unidos nos conflitos que tiveram entre três meses (Guerra hispano-cubano-americana) e três anos - no caso filipino - acabou por destruir os últimos resquícios do Império espanhol nas Américas. Com as derrotas, Cuba e Porto Rico passaram em menor ou maior grau ao controle norte-americano, além da inclusão das Filipinas e Guam nos acordos finais do Tratado de Paris. Assim, com o chamado "Desastre de 98", a Espanha foi relegada a um posto extremamente marginal, tanto nas áreas de influência política, como no campo econômico.

Essa condição pode ser percebida na Tabela 2.1, com a queda do fluxo comercial para Cuba e com os seus principais parceiros comerciais na trajetória entre o século XIX e a década de 1910. Embora não apresentasse a totalidade dos países latino-americanos, os casos cubano e argentino podem trazer um panorama otimista das relações comerciais com outros países da região, pois eram os principais parceiros comerciais do Estado espanhol na porção latina do continente: 


\begin{tabular}{|c|c|c|c|c|c|c|c|}
\hline \multicolumn{7}{|c|}{ 2.1. - Distribuição geográfica do comércio exterior espanhol (1827-1913). } \\
Principais países (\%) \\
\hline \multicolumn{7}{|c|}{ Exportacões } \\
\hline Anos & Alemanha & $\begin{array}{c}\text { Grã- } \\
\text { Bretanha }\end{array}$ & França & Itália & $\begin{array}{c}\text { Estados } \\
\text { Unidos }\end{array}$ & Cuba & Argentina \\
\hline 1827 & 4,1 & 28,3 & 27,9 & 5,0 & 3,0 & 16,6 & 0,0 \\
\hline $1855 / 59$ & 1,7 & 25,6 & 26,4 & 2,9 & 5,2 & 19,4 & 2,5 \\
\hline $1875 / 79$ & 1,3 & 36,9 & 22,2 & 0,9 & 3,0 & 15,2 & 3,1 \\
\hline $1890 / 94$ & 1,4 & 23,0 & 37,9 & 1,0 & 2,1 & 14,7 & 1,3 \\
\hline $1910 / 13$ & 5,9 & 21,4 & 24,9 & 3,5 & 5,8 & 5,3 & 6,1 \\
\hline & & & $\underline{\text { Importaç̃es }}$ & & \\
\hline 1827 & 1,7 & 30,4 & 35,1 & 4,5 & 0,8 & 20,3 & 0,0 \\
\hline $1855 / 59$ & 0,8 & 19,4 & 33,0 & 1,8 & 11,2 & 12,2 & 0,8 \\
\hline $1875 / 79$ & 2,4 & 28,1 & 28,4 & 2,2 & 12,2 & 5,3 & 1,1 \\
\hline $1890 / 94$ & 3,5 & 21,3 & 28,8 & 2,1 & 10,0 & 4,5 & 1,5 \\
\hline $1910 / 13$ & 9,9 & 17,7 & 15,8 & 1,3 & 11,8 & 0,3 & 4,6 \\
\hline
\end{tabular}

Fonte: PRADOS DE LA ESCOSURA, Leandro. De imperio a nación. Crecimiento y atraso económico en España (1780-1930). Madrid: Alianza Editorial, 1993, p. 183-184.

As consequências das derrotas foram bastante profundas nos contatos ibero-americanos. A participação mais perceptível da influência espanhola deu-se com os fluxos migratórios nas primeiras décadas do século passado, com a ausência quase total das relações diplomáticas formais. Algumas poucas tentativas de reaproximação junto ao continente deram-se somente no decorrer da Ditadura do General Primo de Rivera (1923-1930), por meio de interesses econômicos e por destacar o processo migratório recente como parte da "perpetuação" da presença espanhola na América Latina. O ponto culminante dessas tentativas de aproximação ocorreu sob a forma, em Sevilha, da realização da Exposição Ibero-americana em 1929. No entanto, a lógica de preparação e exibição da exposição na Espanha denota um caráter ainda sustentado em princípios conservadores e nostálgicos. ${ }^{138}$

No entanto, as tentativas de aproximação não se traduziram em um aumento na proporção do setor comercial externo junto a uma ampla parcela dos países latino-americanos.

\footnotetext{
${ }^{138}$ HERRERO, Pedro Pérez. op. cit., In: PEREIRA, Juan Carlos (coord.). La política exterior de España (1800-
} 2003). Barcelona: Editorial Ariel, p. 322, 2003. 


\begin{tabular}{|c|c|c|c|c|c|c|}
\hline \multicolumn{7}{|c|}{$\begin{array}{l}2.2 \text { - Comparação do comércio espanhol com os países latino-americanos (1931) } \\
\text { (Em \%) }\end{array}$} \\
\hline \multirow[t]{2}{*}{ País } & \multicolumn{2}{|c|}{ Espanha } & \multicolumn{2}{|c|}{ Estados Unidos } & \multicolumn{2}{|c|}{ Grã-Bretanha } \\
\hline & Importação & Exportação & Importação & Exportação & Importação & Exportação \\
\hline Argentina & 4,1 & 1,2 & 15,8 & 6,0 & 21,0 & 39,0 \\
\hline Bolívia & 0,9 & - & 25,2 & 5,0 & 16,5 & 82,1 \\
\hline Brasil & 0,9 & 0,7 & 25,0 & 43,6 & 17,5 & 7,2 \\
\hline Chile & 1,4 & 2,6 & 34,3 & 33,4 & 16,0 & 16,3 \\
\hline Colômbia & 2,0 & 0,3 & 41,9 & 80,2 & 16,1 & 2,6 \\
\hline Costa Rica & 1,5 & - & 51,8 & 23,0 & 11,2 & 60,3 \\
\hline Cuba & 5,2 & 1,5 & 57,3 & 74,9 & 5,3 & 13,9 \\
\hline Equador & 1,9 & 4,7 & 37,5 & 46,2 & 18,2 & 3,6 \\
\hline Guatemala & 1,2 & 0,1 & 54,9 & 35,4 & 8,9 & 2,1 \\
\hline Haiti & 0,1 & 0,4 & 68,7 & 8,1 & 7,0 & 8,5 \\
\hline Honduras & - & - & 71,6 & 72,4 & 4,7 & 6,0 \\
\hline México & 2,1 & 0,2 & 66,8 & 61,1 & 7,2 & 12,0 \\
\hline Paraguai & 5,6 & - & 16,1 & 0,5 & 12,3 & 0,1 \\
\hline Peru & 0,9 & 0,1 & 40,5 & 36,4 & 14,1 & 21,5 \\
\hline $\begin{array}{c}\text { Rep. } \\
\text { Dominicana }\end{array}$ & 2,4 & 1,8 & 58,0 & 26,2 & 5,0 & 30,9 \\
\hline Uruguai & 4,0 & 0,5 & 19,3 & 4,4 & 19,0 & 35,4 \\
\hline
\end{tabular}

Fonte: VIÑAS, Angel et al. op. cit., 1979, p. 33.

Com o advento da Segunda República, iniciou-se uma alteração, ainda que tímida e conflituosa, em relação à América Latina. Por um lado, o novo regime do Estado espanhol encarou as antigas colônias, com seus regimes republicanos, salvo os hiatos ditatoriais, como modelo. Este novo olhar sobre o continente latino-americano, que levava a reboque aquele que se tinha sobre a própria Espanha, provocou um embate interno e estava imerso em uma dicotomia entre os círculos progressistas e tradicionais envolvidos após o surgimento do regime republicano espanhol em 14 de abril de 1931.

Após o hiato provocado por um distanciamento que perdurou até 1931, o governo espanhol passou a utilizar-se de estratégias para uma maior aproximação junto aos imigrantes espanhóis, por meio da intervenção em assuntos políticos, da criação de novas embaixadas e de reforma no corpo diplomático. Essas atitudes visavam atingir o máximo possível de imigrantes, ou mesmo latino-americanos, sem que houvesse distinções de caráter político. Essa prática fica 
clara quando a Espanha se tornou o único Estado europeu que reconheceu o governo revolucionário de Grau San Martín em Cuba, em setembro de 1933. Os governos republicanos se mostraram também muito interessados em intervir na revolução pacífica dos conflitos interamericanos. De forma destacada, não diminuíram os interesses de Madri em conseguir o utópico objetivo de substituir os Estados Unidos no papel central que ocupava na América Latina, especialmente utilizando de novo a Sociedade das Nações, em que se veio à tona a possibilidade de que a Espanha liderasse de alguma forma os Estados ibero-americanos, chegando a elaborar planos precisos de atuação na região. ${ }^{139}$

Embora o Ministério de Estado tivesse criado novos organismos que possibilitavam ações políticas, comerciais e culturais de maior interesse, as modificações foram tímidas. A intenção de efetuar uma presença mais efetiva na América Latina esbarrou em alguns obstáculos, como a fragilidade e a instabilidade tanto do novo governo republicano, como do conturbado contexto internacional. Dessa forma, as atitudes do governo republicano se restringiram à elevação de escritórios de negócios e legações ao patamar de embaixada, como no caso do México, em 1931, e do Brasil, em 1933. ${ }^{140}$

Em uma mão-dupla de análise, se tomarmos tanto as especificidades da Espanha, como do Brasil, a partir da Tabela 2.2 na qual apresentou-se, de forma comparativa, o fluxo comercial no continente americano, vêm à tona as considerações de Lenin sobre o processo imperialista e a concentração de capital. Em sua comparação sobre o imperialismo nas políticas coloniais, o revolucionário russo afirma que:

\begin{abstract}
(...) é necessário tomar nota que o capital financeiro e sua política exterior, que é a luta das grandes potências pela partilha econômica e política do mundo, originam diversas formas transitórias de dependência estatal. Não somente existem os dois grupos fundamentais de países - os que possuem colônias e as colônias -, mas também é característico dessa época as formas variadas de países dependentes que, desse um ponto de vista forma, são politicamente independentes, mas que em realidade se encontram envolvidos nas redes da dependência financeira e diplomática. ${ }^{141}$
\end{abstract}

Ao continuar sua análise, Lenin aborda as condições de Portugal. No interior da lógica do atraso do capitalismo ibérico, característico do cenário produtivo e societário lusitano e espanhol, suas considerações contribuem para o debate estabelecido:

\footnotetext{
${ }^{139}$ CERVANTES, Ángel; PEREIRA, Juan Carlos. Op. cit., 1992, p. 42.

${ }^{140}$ Ibidem, p. 44.

${ }^{141}$ LENIN, Vladimir Ilitch. Obras selectas. Tomo I (1898/1916). Buenos Aires: Ediciones IPS, 2013, p. 573.
} 
Sempre existiram relações desse tipo entre pequenos e grandes Estados, mas na época do imperialismo capitalista se convertem em sistema geral, forma parte do conjunto de relações que regem a "partilha do mundo" e se convertem em elos da cadeia de operações do capital mundial. ${ }^{142}$

O sistema geral, no caso brasileiro e espanhol, foi indissociável da trama que envolveu: a irrelevância pautada pela condição de ambos os países no cenário interno e os impactos das potências estrangeiras desde, ao menos, o século XIX. Assim, ambos se encontravam do lado da partilha do mundo que deveria ser subjugada verticalmente, com as relações comerciais hispano-brasileiras no sentido horizontal sendo postas em um plano distante.

\begin{tabular}{|c|c|c|c|c|c|c|c|}
\hline \multicolumn{7}{|c|}{$\begin{array}{c}\text { 2.3 - Média quinquenal da participação brasileira no comércio externo espanhol. } \\
\text { Porcentagem em relação ao total comercializado pela Espanha (1929-1935) }\end{array}$} \\
\hline \multirow{3}{*}{ Importações } & $\mathbf{1 9 0 0 - 1 9 0 4}$ & $\mathbf{1 9 0 5 - 1 9 0 9}$ & $\mathbf{1 9 1 0 - 1 9 1 3}$ & $\mathbf{1 9 1 5 - 1 9 1 8}$ & $\mathbf{1 9 2 0 - 1 9 2 5}$ & $\mathbf{1 9 2 6 - 1 9 3 0}$ & $\mathbf{1 9 3 1 - 1 9 3 5}$ \\
\cline { 2 - 8 } & 0,86 & 0,89 & 0,89 & 1,16 & 0,83 & 0,97 & 0,42 \\
\hline \multirow{3}{*}{ Exportações } & $\mathbf{1 9 0 0 - 1 9 0 4}$ & $\mathbf{1 9 0 5 - 1 9 0 9}$ & $\mathbf{1 9 1 0 - 1 9 1 3}$ & $\mathbf{1 9 1 5 - 1 9 1 8}$ & $\mathbf{1 9 2 0 - 1 9 2 4}$ & $\mathbf{1 9 2 5 - 1 9 2 9}$ & $\mathbf{1 9 3 1 - 1 9 3 5}$ \\
\cline { 2 - 8 } & - & - & - & - & 1,21 & 0,71 & 0,69 \\
\hline
\end{tabular}

Fonte: TENA, Antonio. op. cit., In: CARRERAS, Albert y TAFUNELL, Xavier (Coords.). op. cit., 2005, p. 614625 .

Entre 1929 e 1935, mesmo com as distintas alterações no âmbito político e econômico no plano mundial e nas alterações de regimes no Brasil e na Espanha, o volume comercial entre os dois países se manteve estável em termos da balança comercial brasileira, com a predominância do comércio com a Argentina, Estados Unidos, França, Grã-Bretanha e Alemanha. A escassez das relações hispano-brasileiras, do ponto de vista do Brasil, pode ser observada na Tabela 2.4. ${ }^{144}$

\footnotetext{
${ }^{142}$ LENIN, Vladimir Ilitch. Obras selectas. Tomo I (1898/1916). Buenos Aires: Ediciones IPS, 2013, p. 573.

143 De acordo com Tena, foi seguida a classificação dos anuários das Nações Unidas para as exportações e importações. As estatísticas de 1923 não oferecem a distribuição geográfica do comércio. Cf. TENA, Antonio. "Sector Externo" In: CARRERAS, Albert y TAFUNELL, Xavier (Coords.). Estadísticas históricas de España.

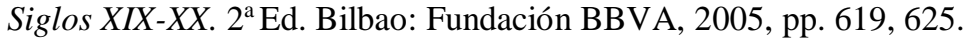

${ }^{144}$ A preferência pela utilização dos dados do IBGE deu-se pela situação dos índices das relações comerciais espanholas, especialmente no decorrer da Guerra Civil Espanhola, que são extremamente irregulares pela falta de sua coleta. A abordagem dessa especificidade da Espanha está em constante reanálise devido ao surgimento de novos vestígios documentais. Dois trabalhos estabelecem um panorama acerca da construção das estatísticas do comércio exterior espanhol: TENA, Antonio. op. cit., 1992; MARTINEZ RUIZ, op. cit., 2006.
} 


\begin{tabular}{|l|l|l|l|l|}
\hline \multicolumn{5}{|c|}{ 2.4 - Comércio do Brasil com a Espanha (1931-1935) } \\
\hline & \multicolumn{2}{|c|}{ Importação } & \multicolumn{2}{c|}{ Exportação } \\
\hline & Tonelagem & Contos de Réis & Tonelagem & Contos de Réis \\
\hline 1931 & 21.538 & 17.638 & 21.035 & 25.022 \\
\hline 1932 & 25.818 & 17.188 & 22.908 & 20.547 \\
\hline 1933 & 16.961 & 24.523 & 4.033 & 7.599 \\
\hline 1934 & 9.795 & 24.064 & 5.371 & 10.617 \\
\hline 1935 & 6.640 & 31.988 & 7.727 & 14.812 \\
\hline
\end{tabular}

Fonte: BRASIL. MINISTÉRIO DA FAZENDA. SERVIÇO DE ESTATÍSTICA ECONÔMICA E FINANCEIRA DO TESOURO NACIONAL. Quadros Estatísticos. No. 3-Q.E.A. 1932-1939. Rio de Janeiro: Imprensa Nacional, 1940, p. 34.

Os resultados das fracas relações comerciais bilaterais, podiam ser observadas om a porcentagem da participação comercial que os dois países possuíam entre si no mesmo período. Do ponto de vista do comercializado pelo Brasil:

\begin{tabular}{|c|c|c|}
\hline \multicolumn{3}{|c|}{ 2.5 - Participação das relações comerciais com a Espanha } \\
\multicolumn{2}{|c|}{ Porcentagem em relação ao total comercializado pelo Brasil (1929-1935) } \\
\hline & Importações & Exportações \\
\hline 1929 & 0,86 & 0,82 \\
\hline 1930 & 0,89 & 0,87 \\
\hline 1931 & 0,89 & 0,73 \\
\hline 1932 & 1,16 & 0,78 \\
\hline 1933 & 1,07 & 0,28 \\
\hline 1934 & 0,97 & 0,31 \\
\hline 1935 & 0,81 & 0,35 \\
\hline
\end{tabular}

Fonte: Instituto Brasileiro de Geografia e Estatística. Repertório Estatístico do Brasil. op. cit., 1941.

Se pelo lado brasileiro não existiam grandes reações frente ao diminuto comércio com o Estado espanhol, em princípios de 1935, a Camara Oficial Española de Comercio e Industria en Rio de Janeiro enviou ao embaixador espanhol um relatório pormenorizado dos fluxos comerciais dos países entre os anos de 1931 e 1933. Ao analisar a situação do comércio entre os dois países, a Camara argumentava que as dificuldades e diminuições nos fluxos de mercadorias se concentravam mais nos problemas internos do Brasil, do que em circunstâncias de origem espanhola. 
A posição real do intercâmbio comercial hispano-brasileiro não nos é dado nas cifras que obtemos, pois, inclusive, somente chegam até 1933. Em 1934, a situação piorou não somente pela diminuição do poder de compra do Brasil, mas pelo bloqueio de créditos, que sem analisar suas origens e causas, seus efeitos não poderiam ser senão os de contribuir à redução das transações comerciais. ${ }^{145}$

Entretanto, ao abordar as estratégias de exportadores e importadores de ambos os países, o informe não hesita em apontar os pontos deficitários nas ações comerciais dos produtores espanhóis e de sua representação em território brasileiro:

Até [1]933 as compras do Brasil poderiam talvez terem sido maiores, para as quais, tivesse contribuído uma propaganda maior ou melhor orientada, feita pelos exportadores lá na Espanha e pelos representantes aqui, que nem todos pensam no futuro, senão que vivem às vezes no presente procurando um lucro fácil e obstaculizam a difusão de seu artigo no mercado. Justamente em nossa Câmara se observou que existem produtos que após ter a sua clientela no Rio, vão saindo do mercado por falta de estoque e ao desaparecer o representante significa organização defeituosa da propaganda. Mas devemos ser justos e assinalar que o Brasil inclusive, aumentou seus gastos na Espanha até 1933, adquirindo mercadorias por valor maior em moeda nacional que nos anos anteriores. ${ }^{146}$

Ao compararmos as quantidades gerais de importação brasileira percebe-se que as mercadorias de origem espanhola acompanham o mesmo ritmo. Na quantidade geral da importação de minerais, a demanda brasileira por ferro e aço sofreu uma queda de $60 \%$ em 1933 frente ao que havia sido comercializado nos dois anos anteriores. No ano de 1934, até junho, esse índice havia sofrido uma pequena melhora, com patamares próximos aos de 1930. E, mesmo sendo um dos principais produtos de exportação espanhola, a quantidade vinda para o Brasil reduziu-se de forma significante, com uma queda de $33 \%$ em $1934 .{ }^{147}$

No caso dos alimentos, a situação não destoava frente aos produtos de mineração. No cômputo geral, a importação de azeite, em 1934, havia diminuído em torno de $60 \%$, se comparado com 1930 e os de origem espanhola houve o consumo de somente $38 \%$. A importação do sal comum sofreu uma agressiva diminuição. Nos seis primeiros meses de 1934, foram adquiridos apenas $24 \%$ do que foi em 1930, o que representava uma pequena melhora frente ao ano de 1933, com apenas 19\%; e, aquele originário da Espanha teve uma queda de $50 \%$, sobre a base de 1930. Somente a importação de frutas frescas seguiu um caminho distinto,

\footnotetext{
${ }^{145}$ Informe comercial n ${ }^{\mathrm{o}} 31$. Da Camara Oficial Española de Comercio e Industria en Rio de Janeiro al Embajador Español. 16/01/1935, p. 04. AGA.

146 Ibidem.

${ }^{147}$ Ibidem, p. 05. AGA
} 
com um aumento de três vezes mais do que em 1930, com o crescimento daquelas originárias da Espanha, em torno de 20\%. ${ }^{148}$

Mesmo com o comércio bilateral restrito, como apontado, o governo republicano rastreou as possibilidades de se aumentar o comércio entre os dois países. O mapeamento realizado atendia, essencialmente, aos interesses da oligarquia espanhola para um acréscimo de vendas de produtos primários, assim as principais áreas industriais da Espanha e seus produtos não eram nem citados. Esse sintoma coadunava-se com o predomínio do próprio corpo político conservador à frente do Estado espanhol no ano de 1935.

Em um quadro elaborado pela própria Camara, tomou-se como ponto de partida para uma maior oferta de produtos espanhóis, as mercadorias que eram parte integrante das importações brasileiras e que poderiam ser fornecidas desde a Espanha:

\begin{tabular}{|c|c|c|c|}
\hline \multicolumn{5}{|c|}{ 2.6 - Prospecção espanhola para comércio com o Brasil (1935) } \\
\hline $\begin{array}{c}\text { Importado pelo } \\
\text { Brasil }\end{array}$ & $\begin{array}{c}\text { Possibilidade de } \\
\text { exportação espanhola }\end{array}$ & $\begin{array}{c}\text { Exportado pelo } \\
\text { Brasil }\end{array}$ & $\begin{array}{c}\text { Possibilidade de } \\
\text { importação espanhola }\end{array}$ \\
\hline Carvão & Sim & Carne Conservada & Sim \\
\hline Cimento & Sim & Carne congelada & Sim \\
\hline Ferro e aço & Sim & Couros & Sim \\
\hline Massa para papel & Sim & Algodão & Sim \\
\hline Peles & Sim & Açúcar & Sim \\
\hline Tecidos de algodão & Sim & Cacau & Sim \\
\hline Cobre & Sim & Café & Sim \\
\hline Chumbo & Sim & Madeiras finas & Sim \\
\hline Louça, porcelana & Sim & Dormentes & Sim \\
\hline $\begin{array}{c}\text { Máquinas } \\
\text { e acessórios }\end{array}$ & Sim & Mate & Sim \\
\hline Azeite & Sim & Tabaco & \\
\hline Bacalhau & Sim & & \\
\hline Trigo & Não & & \\
\hline Bebidas alcoólicas & Sim & & \\
\hline Frutas de mesa & Sim & Sim & \\
\hline Sais potássicos & Sim & & \\
\hline
\end{tabular}

Fonte: Informe comercial $\mathrm{n}^{\mathrm{o}}$ 31. Da Camara Oficial Española de Comercio e Industria en Rio de Janeiro al Embajador Español. 16/01/1935, p. 07. AGA.

De acordo com a avaliação inicial da Camara, perante a situação de desvalorização da moeda espanhola após a crise de 1929, haveria a tendência de que o comércio hispano-brasileiro poderia ter um acréscimo com compensações para se obter produtos que seriam mais baratos.

\footnotetext{
${ }^{148}$ Informe comercial n ${ }^{\text {3 }}$ 31. Da Camara Oficial Española de Comercio e Industria en Rio de Janeiro al Embajador Español. 16/01/1935, p. 04. AGA.
} 
Entretanto, ressaltou-se a condição de submissão dos dois países perante o imperialismo internacional, pois para eles existiam,

(...) razões que temos de buscar na trama geral da política econômica fizeram com que Espanha e Brasil, dentro da linha média de redução do comércio mundial situação comum, em todas as nações do mundo civilizado, adquiriram de outros países, seguramente a preço menos convenientes, produtos que antes compravam diretamente entre si. ${ }^{149}$

E, mesmo ao apresentar um cenário de que um acréscimo nas relações entre os dois países não ocorreria de forma acelerada, a Camara demandou que houvesse maior empenho dos governantes de ambos os países. Uma das estratégias apresentadas se sustentava no direcionamento dos produtos espanhóis para os imigrantes e descendentes daquele país radicados no Brasil. E, devido à própria condição de penúria na qual viviam, se aumentaria a quantidade consumida, pois seriam obtidos por valores mais baixos do que aqueles existentes em produtos oriundos das grandes potências. Uma estratégia que seria benéfica para o Estado e produtores espanhóis, mesmo com as perspectivas da manutenção de uma balança comercial deficitária frente o Brasil. ${ }^{150}$ A proposta apresentada coadunava-se com a avaliação sobre o processo de diversificação de importações brasileiras estabelecida durante a década de 1930, além de ressaltar o cenário interno de crise econômica enfrentada pelo governo Vargas:

Dada a crise econômica do Brasil, que não é por uma diminuição de produção, nem pela discutível qualidade dos produtos, senão por uma defeituosa arrecadação interna somada às suas enormes dívidas externas em quantidade mais elevada que em outros países, devido a isso, que para o meio ambiente brasileiro improvisado e querendo ganhar muito com pouco esforço, os Governos se viram forçados a buscar quase sempre o dinheiro estrangeiro, fácil de conseguir em seu momento e mais barato que o dinheiro interno, mas ao que há de vir pela falta de confiança, dada à instabilidade política, se está produzindo a quebra do Brasil. ${ }^{151}$

O caráter exposto, em janeiro de 1935, não era casuístico ou uma tentativa desesperada de se ampliar as exportações espanholas para o Brasil, embora, como foi ressaltado, os patamares comerciais eram extremamente baixos.

\footnotetext{
${ }^{149}$ Informe comercial n ${ }^{\circ}$ 31. Da Camara Oficial Española de Comercio e Industria en Rio de Janeiro al Embajador Español. 16/01/1935, p. 8. AGA.

${ }^{150}$ Ibidem, p. 9. AGA.

${ }^{151}$ Ibidem, p. 10. AGA
} 
Em outubro de 1935, a Camara apresentou o diagnóstico do que, de forma presumida, impedia um crescimento do comércio bilateral: o sistema de caixa de compensações o qual a Espanha estava submetida.

Assim se está sucedendo entre o Brasil e a Espanha. Na Espanha somente se desbloqueia se recebe mercadorias brasileiras; no Brasil somente pode o importador de artigos espanhóis comprar pesetas para o pagamento de suas letras vencidas se o Banco do Brasil - ou outro da praça - dispõe de divisas espanholas.

(...)

Somente temos pesetas se exporta mercadoria brasileira para a Espanha. ${ }^{152}$

Uma das estratégias específicas que foi cogitada pela Camara residia no fluxo da principal mercadoria de exportação brasileira, tanto para o Estado espanhol como para o resto do mundo:

A solução é única; a prática o diz; o prova até saciar; Espanha tem que comprar café do Brasil. ${ }^{153}$

A afirmação acima concentrava a solução do problema para a obtenção de pesetas para a caixa de compensação Brasil-Espanha a partir dos impostos indiretos que recaíam sobre os exportadores de café. Ademais, também seria necessário que a balança comercial fosse favorável ao Estado espanhol.

Em grande medida, atribuía-se responsabilidade ao governo Vargas por tentar solucionar as condições provisórias que abarcavam as relações comerciais brasileiras:

Antes de 1931, o Brasil não possuía propriamente uma política comercial. É certo que havia celebrado alguns convênios que tinham por objetivo garantir a entrada do café em diferentes países, em condições não inferiores às concedidas aos seus competidores, mas sem nenhuma preferência. ${ }^{154}$

A "culpa" da não existência de uma política comercial brasileira já havia sido identificada em 1934, pela Camara Oficial Espãnola de Comércio e Industria: a denúncia, pelo

\footnotetext{
${ }^{152}$ Informe comercial n ${ }^{\circ} 31$. Da Camara Oficial Española de Comercio e Industria en Rio de Janeiro al Embajador Español. 16/01/1935, p. 9. AGA

${ }^{153}$ Informe $n^{\circ}$ 1166-1935. Da Camara Oficial Española de Comercio e Industria en Rio de Janeiro al Embajador Español. 28/10/1935, p. 9. AGA

154 “Los acuerdos comerciales del Brasil actualmente en Vigor." Servicio Comercial del Ministerio de Asuntos Exteriores. 28/09/1934, p. 01. AGA
} 
Governo Provisório de Vargas, dos acordos comerciais existentes no decreto publicado em 8 de setembro de 1931,

Art. $1^{\circ}$. O Ministerio da Fazenda procederá, sem demora à revisão integral da Tarifa das Alfandegas da República, procurando conciliar os interesses do fisco com os da lavoura, da indústria e do comércio do país. ${ }^{155}$

O prazo para a conclusão da revisão deveria ser de seis meses, para que de forma acelerada fossem estabelecidos novos acordos comerciais externos. E, dois anos depois, os acertos comerciais com os outros países não haviam ainda sido concluídos. Umas das tentativas iniciais do governo varguista em iniciar o seu primeiro ciclo ascendente ${ }^{156}$ havia se tornado, para o Estado espanhol, mesmo em 1935, um impeditivo para o aumento de suas exportações junto ao Brasil. Uma esperança que já havia sido aventada no ano anterior:

Estão em vias de preparação no momento, as negociações para a conclusão de tratados com os Estados Unidos da América e com a Espanha. Ambos teriam seu ponto inicial nas taxas das novas tarifas de aduana e por tal razão não poderiam ser iniciadas até depois da conclusão da mencionada da nova tarifa publicada no "Diário Oficial" de junho de 11 de junho último e que entrou em vigor em $1^{\circ}$. de setembro de $1934 .{ }^{157}$

É claro que o comércio com os Estados Unidos possuía uma importância muito maior, tanto pelo lado brasileiro, como pelo norte-americano, no contexto das assinaturas que Vargas fez junto à Alemanha. Destarte, o desprezo recebido pelo Estado espanhol somente tentou ser superado pelo governo republicano após a sublevação militar de julho do ano seguinte.

No campo comercial entre os dois países, os efeitos dos primeiros seis meses de 1936, não alteraram as restritas trocas entre eles, pois sem maiores aprofundamentos do comércio bilateral entre Brasil e Espanha, o que estava ainda em voga era o acordo comercial provisório de 1931. A constituição de novos termos comerciais entre os dois países, voltou a se fazer premente, ao menos do lado espanhol, com a deflagração do movimento de 17 de julho, em que houve a tentativa da Segunda República em estabelecer um novo acordo:

Agradeço profundamente à Vossa Excelência a amável notificação que há tido o bem de me fazer, significando que o meu Governo está animado pelo melhor

\footnotetext{
155 “Decreto no. 20.380” In: Diário Oficial da União. Seção 1, 11/09/1931, p. 14382.

156 Cf. BARBOSA, Wilson do Nascimento. Balanço da Economia Brasileira, 1940-1980. São Paulo: LCTE Editora, 2006.

157 "Los acuerdos comerciales del Brasil actualmente en Vigor." Servicio Comercial del Ministerio de Asuntos Exteriores. 28/09/1934, p. 3. AGA
} 
desejo para poder chegar o quanto antes a um Acordo Comercial com o Brasil que regularize definitivamente o intercâmbio entre os nossos dois países e que desta forma espero que para a data de 10 do atual possa ficar ultimado o Acordo provisório que se negocia. ${ }^{158}$

O aceleramento da criação de um novo veio por parte do embaixador espanhol Teodomiro Aguilar, embutida à pressão que o representante republicano exercia, situava-se uma dupla estratégia. Uma delas era a de ao estabelecer um acordo comercial permanente, promover, ainda que indiretamente, a manutenção do Estado espanhol republicano como oficial; e, por outro lado, de garantir os fluxos comerciais que poderiam escassear com a guerra.

Envolto nos conflitos internos para decidir o papel brasileiro em razão da insurgência militar no Estado espanhol, houve uma nova prorrogação até o dia 10 de agosto, a partir de um acordo comercial provisório, que estava em vigência e em vias de ser concluído. No entanto, mais uma prorrogação foi feita até o dia 15 de setembro. No entanto, no mesmo dia, o ministro brasileiro em exercício, Mario de Pimentel Brandão, propôs a manutenção, sem prazo de validade, mas com a adição de uma cláusula de denúncia, ou seja, do seu cancelamento, que deveria ser feito com uma antecedência de 30 dias. ${ }^{159}$

Contudo, um novo acordo somente seria alcançado ao final da guerra intestina espanhola, em 1939, já sob os auspícios do governo franquista.

\subsection{Embates internos e influências externas no posicionamento brasileiro}

A tomada de decisão do que fazer frente à questão espanhola, envolveu os nódulos da cúpula do Estado varguista com a influência política das representações diplomáticas brasileiras no exterior. Neste último caso, foi de capital importância o papel representado pelos diplomatas, principalmente aqueles lotados no Estado espanhol, como foi o caso do embaixador Alcebíades Peçanha e de Oswaldo Aranha, então embaixador brasileiro em Washington. Assim, se por um lado a importância de Peçanha se apresentava per se ao estar lotado em Madri, a de Aranha vinculava-se ao papel que os Estados Unidos possuíam na conjuntura continental e na política externa brasileira.

Enquanto na primeira quinzena, após o pronunciamiento militar de 17 de julho, era eminente o silêncio do governo brasileiro, as primeiras notícias vinculadas ao conflito intestino espanhol centravam-se, ainda que de forma hesitante, em um discurso de caráter legalista das

\footnotetext{
${ }^{158}$ Do embaixador espanhol Teodomiro de Aguilar ao Ministro José Carlos de Macedo Soares. Rio de Janeiro, 1 de agosto de 1936. AHI.

159 Do Ministro Mario de Pimentel Brandão ao embaixador espanhol Teodomiro. Accordo Comercial Provisorio entre o Brasil e a Hespanha. Rio de Janeiro, 15 de setembro de 1936. AHI.
} 
relações hispano-brasileiras. Esse sintoma inicial se traduziu, ao menos nos jornais de grande circulação, como a manutenção do status quo do governo republicano espanhol nas relações externas brasileiras:

(...) o Itamaraty não reconhecerá a Junta Militar de Burgos, na Hespanha, em virtude de existir em Madrid um governo legal que não interrompeu as relações diplomáticas com o nosso paiz. ${ }^{160}$

No entanto, a notícia publicada na Folha da Manhã se coadunava com a situação interna que perpassava o governo brasileiro. Por um lado, se havia a publicidade externa de um posicionamento de não-intervenção nos assuntos espanhóis, por outro, no interior da administração varguista, os debates acerca do posicionamento brasileiro frente ao conflito não eram unânimes.

Na primeira quinzena de agosto de 1936, as discussões feitas no Rio de Janeiro, no ínterim do primeiro mês, que envolveram diretamente o ministro de relações exteriores, José Carlos de Macedo Soares, e o próprio Getúlio Vargas tomam um maior destaque. De acordo com este último,

O ministro do Exterior procura-me com um pesado cartapácio de informações sobre a Espanha, propondo uma manifestação do Brasil no sentido de definirse a favor dos rebeldes, ou pelo reconhecimento da beligerância destes, ou por outro ato qualquer que [tenha] por objetivo uma quebra de neutralidade. ${ }^{161}$

Ainda que não tivesse sido o primeiro encontro entre os dois para se abordar a sublevação militar no Estado espanhol, o posicionamento de Macedo Soares trazia certo incômodo a Vargas:

(...) o ministro do Exterior insistiu, apresentando-me o esboço de um decreto, pela declaração de neutralidade do Brasil na Guerra Civil da Espanha. Novamente recusei-me em concordar com tal atitude. É uma questão de política interna da Espanha que só cabe a esta intervir, não nos competindo opinar no assunto sobre o qual ninguém nos consultou. ${ }^{162}$

\footnotetext{
${ }^{160}$ Folha da Manhã, 01/08/1936, p. 1

161 “10/08/1936” In: VARGAS, Getúlio. Diário. São Paulo/Rio de Janeiro: Siciliano/Fundação Getúlio Vargas, 1995 , p. 53. 
O desconforto apresentado se vinculava ao próprio princípio de neutralidade. Pois ao adotá-lo, o governo brasileiro, de forma subsumida, avalizava as ações de parte do oficialato espanhol contra o governo republicano.

No entanto, enquanto Vargas escrevia a respeito das conversas com Macedo Soares, se estabeleceu uma abordagem de consulta junto ao governo dos Estados Unidos. Para tal empreitada, ao invés de solicitar, por meio de seu ministro de relações exteriores, informações junto ao Departamento de Estado do governo Roosevelt, se utilizou de Oswaldo Aranha, então embaixador em Washington, para o envio de um telegrama que solicitava:

(...) carater reservado se governo americano pretende fazer declaração guerra civil Hespanha, conforme jornais aqui noticiam. ${ }^{163}$

A relutância estratégica de Vargas em interferir no conflito, mesmo com a pressão oriunda do Itamaraty e de seus contatos com o seu embaixador em Washington, emergia como mais um dos sintomas do fracionamento do cenário político brasileiro da década de 1930. A contenda entre o comando do Itamaraty e Vargas, acerca do posicionamento brasileiro perante a situação no interior do Estado espanhol, ficava clara mais clara. Por um lado, pelo comportamento do próprio Estado brasileiro no instante em que as negociações com os Estados Unidos e a Alemanha se agudizavam, devido principalmente à realização de acordos comerciais e ao aumento no fluxo comercial com este último. E, por outro, a partir das divisões no posicionamento ideológico do corpo diplomático, fossem aqueles no Rio de Janeiro ou os que estavam em postos no exterior, que possuíam uma tendência conservadora-germanófila, ou os de viés mais liberal que mostraram os seus posicionamentos com a Guerra Civil Espanhola.

O conflito interno tornou-se relativamente público quando da divulgação do relatório anual do Ministério de Relações Exteriores. O seu conteúdo se pautou pela não-intervenção brasileira de forma alguma, sob a alegação de que não havia sido constituído um estado de beligerância entre os grupos em disputa em solo espanhol. Ainda que publicado no ano seguinte, o documento apontava que o Brasil,

(...) não deseja intrometter-se de forma alguma em lutas intestinas de qualquer paiz estrangeiro. Depois, parecia-lhe que no, caso em apreço, para haver mediação propriamente dita, deveria previamente ser reconhecido o estado de

163 Telegrama de Getúlio Vargas a Oswaldo Aranha. Rio de Janeiro. GVc1936.08.13 (Vol. XXIII/50). CPDOC/FGV 
belligerancia dos rebeldes, pois o contrário seria abertamente a intervenção na vida interna da Espanha. ${ }^{164}$

No mesmo documento ficou clara uma contradição. Se por um lado, verificava-se de acordo com as considerações de Getúlio, por outro, coadunava-se com as pressões que ele recebia do ministro Macedo Soares:

\begin{abstract}
O desenvolvimento entretanto, assumido pela guerra civil e as medidas de neutralidade adoptadas em conjunto por varias potencias europeias, associadas numa comissão reunida em Londres, já não deixam dúvida quanto à existência de verdadeira guerra civil na Espanha, no sentido jurídico da palavra, e quanto ao reconhecimento implícito da belligerancia dos insurrectos. ${ }^{165}$
\end{abstract}

Entretanto, enquanto o ministro de relações exteriores brasileiro pressionava por um posicionamento, ou seja, a neutralidade e condição de beligerante dos insurgentes militares, que favorecia esses últimos, Oswaldo Aranha despontava suas considerações pelo viés anticomunista.

Aranha, ao associar a Frente Popular espanhola com o movimento internacionalista de expansão do comunismo, mostrou suas preocupações em relação aos efeitos que o desenvolvimento da Guerra Civil Espanhola poderia causar no continente americano, principalmente nos países que foram colônias espanholas. Ao tomar o comunismo como inimigo de primeira ordem, quaisquer que fossem os contatos entre a Segunda República e os países latino-americanos, suas preocupações tomavam maiores dimensões. A sua associação entre a expansão comunista, sobretudo na América Latina, e o conflito espanhol adquiriu contornos mais densos ao abordar a situação do México, que em um período recente havia experimentado um processo revolucionário que apeou do poder, tanto os grupos mais conservadores, como aqueles que tinham ligações mais íntimas com o governo norteamericano.

O Mexico, que está sendo indianizado e bolshevizado pelo proprio governo despachou hontem um navio com armas e munições para o governo hespanhol!

As consequencias deste acto serão graves. Se vencerem os rebeldes, naturalmente, tratarão de favorecer as direitas mexicanas. Se, ao contrário, -

164 BRASIL. MINISTÉRIO DAS RELAÇÕES EXTERIORES. Relatório apresentado ao Dr. Getúlio Vargas, Presidente dos Estados Unidos do Brasil pelo Ministro de Estado de Relações Exteriores. Rio de Janeiro: Imprensa Nacional, 1936, p. 20.

${ }^{165}$ Idem. 
cousa pouco provavel - vencerem as esquerdas hespanholas, a ofensiva comunista e a bolshevização dos paizes indo-hespanhóis é uma ameaça a temer. ${ }^{166}$

No cenário europeu se apresentaram duas situações de análise perante os primeiros seis meses de conflito espanhol: uma delas, foi o posicionamento e os relatos de Alcebíades Peçanha; e a outra, aquelas decorrentes dos envolvidos no processo de tentativa de "apaziguamento" das tensões no teatro da Europa durante o entreguerras, ou seja, Inglaterra e França.

A análise de Alcebídades Peçanha nos primeiros dias, após o início do levante militar, não se distanciava das percepções apresentadas na historiografia da Guerra Civil e das ações "burocráticas" que a embaixada brasileira deveria adotar com o início das ações militares. Enquanto o governo republicano, sediado em Madri, intentava debelar as quarteladas na capital e nas principais cidades do Estado espanhol, principalmente Barcelona, nas regiões mais meridionais e que possuíam maior influência dos caciques locais, o movimento golpista conseguia controlar rapidamente quartéis e centros urbanos. Segundo o próprio diplomata, em um telegrama expedido durante o intervalo de um tiroteio:

Este governo declara que a sublevação das guarnições do Exército está quasi totalmente dominada, pela aviação, a guarda civil, a guarda de assalto e populares em armas, e na zona marroquina. As guarnições de Barcelona e Madrid estão dominadas, havendo numerosos mortos. Os Regimentos de Sevilha, Cadiz, Valladolid e Mlaga continuam resistindo. Estão mantidas as comunicações entre a capital e as províncias, inclusive S. Sebastian, onde se acha o Corpo diplomatico estrangeiro. ${ }^{167}$

De forma concomitante ao avanço das forças militares, também era notada a composição de resistência dos trabalhadores. Como o relato enviado por Peçanha ocorreu no decorrer da primeira semana pós-17 de julho, de forma consciente ou não, atribuía uma composição de milícias que não distinguia ao certo aqueles que as compunham. Ademais, apresentou, pela primeira vez, o comparecimento de atores exógenos ao cenário espanhol:

O Governo Espanhol prossegue na operação contra os focos de sublevação. Esta capital continua policiada por obreiros armados. Entre esses, e os que compõem as milicias, contam-se numerosos communistas, o que preocupa as classes conservadoras. Os rumores me induzem crer que a dominição se

\footnotetext{
${ }^{166}$ Carta de Oswaldo Aranha a Getúlio Vargas. Washington. GVc1936.08.26 (Vol. XXIII/58). CPDOC/FGV 167 "Revolução na Espanha". Telegrama da Embaixada em Madrid à Secretaria de Estado das Relações Exteriores. 24-25/07/1936. AIH
} 
prolongará. Os Estados Unidos e a Inglaterra já enviaram alguns navios de guerra para aguas espanholas. ${ }^{168}$

Enquanto em Madri o embaixador tentava apresentar um cenário inicial do conflito por meio de informações que se originavam mais da vista da sua janela e de outras origens incertas, nas representações brasileiras consulares, em outras regiões do Estado espanhol, ações eram apresentadas de forma mais objetiva ao Itamaraty, sem o intermédio do embaixador em Madri. Desde o consulado brasileiro em Tenerife, ou seja, um dos principais focos do levante militar, Alvaro Magalhães denunciava os atos dos rebelados:

As forças miliares do exercito, revoltadas, tendo dominado esta região, atacaram o edificio do Consulado com cerrado tiroteio, penetrando na Chancellaria a procura de communistas armados hostilizados pelas mesmas. Protestei energica, mas prudentemente, contra a violação dos principios de Direito Internacional, procurei a autoridade militar que se recusou a dar garantias, declarando a necessidade absoluta de reprimir, com violência, a aggressão partida do edificio do Consulado. Presenciei a captura de João Siqueira, communista, portuguez expatriado, marido da porteira e autorizado, pelo meu predecessor, a residir na Chancellaria. As comunicações com a Embaixada em Madrid estão interrompidas. ${ }^{169}$

No Estado espanhol a situação oscilava entre o desencontro de informações, como era o caso de Madri, e a invasão dos sublevados às representações diplomáticas, como ocorreu em Las Palmas. Nesse ínterim, na França, o Embaixador Luís Martins de Sousa Dantas, rapidamente fez eco com a solicitação do governo republicano para que fosse auxiliado no combate aos revoltosos. O pedido que havia sido feito, principalmente do fornecimento de aviões para a força aérea republicana, que havia sido desfalcada com a adesão da maioria de seu corpo aos revoltosos, era uma das tônicas iniciais da ajuda que o Estado espanhol solicitava contra os insurgentes. No entanto, o incipiente governo da Front Populaire française, comandado por León Blum e eleito em 3 de maio de 1936, foi duramente atacado pelos partidos conservadores da Assembleia francesa, quando do pedido de ajuda:

Aviadores espanhoes chegados aqui de improviso, sem passaportes, trouxeram a missão de adquirir quarenta aviões de bombardeio para o Governo espanhol. Corre que as autoridades francezas estariam inclinadas a ceder esse material, allegando a existencia de uma encommenda anterior a actual sedição em Espanha. Os órgãos da direita, comentando o facto,

\footnotetext{
168 "Revolução na Espanha". Telegrama da Embaixada em Madrid à Secretaria de Estado das Relações Exteriores. 24-25/07/1936. AIH

169 Telegrama do Consulado em Las Palmas à Secretaria de Estado das Relações Exteriores. 24/07/1936. AIH
} 
previnem o Governo francez contra a inconveniência e incorreção de intrometter-se este paiz nos negócios internos da Espanha. ${ }^{170}$

Em novembro de 1936, Alcebíades Peçanha comunica ao governo brasileiro as primeiras semanas de combate. É colocado de forma clara que existe uma participação exterior no conflito, principalmente por intermédio de armas e do rápido avanço das tropas rebeladas:

Não obstante a resistencia das milicias governamentaes, superiores em numero e munidas de armamentos modernos, fornecidos pelo Mexico, a França e a Russia, as tropas do General Franco estão ás portas de Madrid. Já se está organizadno a resistencia nas ruas da cidade, a despeito das declarações do Governo que havia affirmado só daria combate nos arredores da Capital. ${ }^{171}$

Segundo Aranha, em relatório enviado a Vargas, em junho de 1937, no qual faz um balanço da situação naquele momento, tanto na América Latina, bem como na Europa, a situação da Espanha é crítica e mostra o entrelaçamento dos interesses americanos na Europa, com a situação da Guerra Civil e os países do Eixo. No tocante ao conflito, o embaixador brasileiro em Washington, expõe, ainda que de forma superficial, a participação de nações estrangeiras e como a guerra civil possuía importância no cenário internacional, pois no decorrer dos confrontos:

A parte que está levando o peor, sejam os rebeldes ou os governistas, procura trazer mais gente para a fogueira. É uma táctica comprehensivel. ${ }^{172}$

Após o bombardeio do navio alemão Deutschland ${ }^{173}$, em Ibiza, pela aviação republicana, Aranha com fina ironia diz que "Era a ajuda necessária no momento em que Bilbao estava ameaçada de todos os lados". ${ }^{174}$ Esse comentário justifica-se pela morte e ferimentos dos marinheiros da embarcação, e, pelo ataque direto ás força alemães, embora objetivasse atacar o Canarias, que estava ao lado do exército rebelado. A represália de Hitler causou o ataque direto à cidade de Almería.

\footnotetext{
170 "Situação politica franceza". Telegrama da Embaixada em Paris à Secretaria de Estado das Relações Exteriores, 24-07-1936. AIH

${ }^{171}$ Telegrama de Alcebíades Peçanha a Getúlio Vargas. Madri, 07-08/11/1936. GV c 36.11.07. Volume XXIV/55a

${ }^{172}$ Carta de Oswaldo Aranha a Getulio Vargas, 06/06/1937. GV c 1937.06.04, volume XXVI/54. p.1-2

${ }^{173}$ O Deutschland foi um navio da classe Deutchland, junto com os seus "irmãos" Almirante Graf Spee e Almirante Scheerer, foi um dos navios produzidos ao fim da década de 1920 e lançado no decorrer da década de 1930, ainda sob os regulamentos do Tratado de Versalhes, após o fim da Primeira Guerra.

${ }^{174}$ Carta de Oswaldo Aranha a Getúlio Vargas, 06/06/1937. GV c 1937.06.04, volume XXVI/54. p.1
} 
Ao tratar da situação espanhola e de um reconhecimento de beligerância, a recomendação de Aranha é a de que o país deve evitar tomar tal atitude e reservar-se ao isolamento, pois "tal acto é desnecessário e será erro [com] consequencias desagradáveis". ${ }^{175}$ Em consonância com a opção de Aranha, Vargas vai no mesmo caminho e afirma que continuaria o posicionamento anterior e que evitaria uma ação isolada do governo brasileiro, com uma atitude que seria tomada somente com a "coordenação outros paízes américa". ${ }^{176}$

A combinação entre os fatores internos do governo Vargas e as incertezas que se colocavam no cenário interno espanhol e europeu, expõe as fraturas internas do próprio Ministério de Relações Exteriores do Brasil. O posicionamento individual do corpo diplomático, no Rio de Janeiro e nas representações no exterior, expôs o governo brasileiro a uma dependência das ações individuais em torno da Guerra Civil Espanhola.

Com as questões políticas pertinentes ao posicionamento brasileiro no conflito, também havia a situação econômica. O posicionamento oficial de neutralidade, por parte do governo Vargas, situava o Brasil em uma ampla planície de governos que haviam adotado a mesma postura. No entanto, quanto ao fluxo comercial e a chegada de mercadorias à zona de conflito houve uma outra dinâmica, que envolveu o próprio princípio de neutralidade assumido.

\subsection{Os contatos e os embarques de 1936}

Uma das questões que estabeleceu o tripé comercial, político e militar das abordagens sobre o governo brasileiro e os primeiros meses da Guerra Civil, foi uma carta recebida por Vargas em outubro de 1936. O "famoso" conteúdo da missiva sustentava um apoio direto feito aos rebelados por meio do envio de açúcar e café. O recebimento foi acusado por um telegrama de agradecimento do próprio Francisco Franco, em outubro de 1936, em que afirma:

Com a mais viva satisfação, tomei conhecimento de seu nobre e generoso gesto de doar às tropas nacionais que lutam em defesa da Espanha e da civilização contra as hordas marxistas, importantes quantidades de açúcar e café. ${ }^{177}$

E, toma um caráter particular e oficioso, ao menos para o doador, de manter as aparências de não demonstrar quaisquer traços de intervenção do governo brasileiro na

\footnotetext{
175 Telegrama de Oswaldo Aranha a Getúlio Vargas, 12/07/1937, GV c 1937.07.12, volume XXVI/80a.

176 Telegrama de Getúlio Vargas a Oswaldo Aranha, 13/07/1937. GV c 1937.07.12, volume XXVI/80b.

177 Carta de Francisco Franco a Getúlio Vargas. Salamanca. GVc1936.10.29/1 (Vol. XXIX/44). CPDOC/FGV
} 
contenda espanhola, principalmente em relação aos rebelados. Assim, Franco complementa que,

Por momento e cumprindo os desejos de V.E., tão importante donativo será mantido dentro da mais estreita reserva até que as circunstâncias permitam divulgá-lo e então todo o povo espanhol possa agradecê-lo. ${ }^{178}$

Como em outras obras do corpo bibliográfico que utilizamos sobre a as relações entre Brasil e o Estado espanhol, ou ainda em perfis biográficos de Vargas, não foram localizadas referências a respeito do tal envio deliberado de café e açúcar aos sublevados. E, tampouco apresentou-se algum tipo de comunicação preliminar antes do envio ou mesmo de réplica à carta de Franco. Diante disso, o que ocorre é que tal remessa se confirmaria somente pela própria existência documental de tal telegrama, sem nenhum cotejo com outros dados ou documentos. Ou ainda, se apresenta somente como mais uma informação sobre o gaúcho de São Borja e suas tendências conservadoras, que já estariam relacionadas a um posicionamento de alinhamento às forças nazifascistas europeias. ${ }^{179}$

No entanto, tomamos esses embarques como concretizados e realizados por meio dos organismos dos militares revoltosos. As chegadas de café e açúcar às regiões já controladas pelas facções do exército sublevado ocorreram de duas formas, uma delas por meio de embarques realizados antes do 17 de julho e as outras após essa data. No primeiro caso, é claro, houve a saída de portos nacionais antes da insurgência; e, no segundo, aqueles que chegaram ao novo controle estabelecido em certos portos e regiões.

No primeiro caso, de forma indireta e pela própria dinâmica do avanço dos insurgentes, não há dúvida de que os contingentes de mercadorias que chegavam ao Estado espanhol podem ter caído em mãos insurgentes. No entanto, devemos atentar para os carregamentos realizados após o 17 de julho.

Inicialmente, ao observarmos as exportações de café para as áreas de controle espanhol, estão computadas, de acordo com o Departamento Nacional do Café, por meio de um critério regional: Espanha, que representa a parte continental do Estado espanhol, o conjunto das Ilhas Canárias e, em terceiro, as possessões espanholas no Norte da África, nominadas como Marrocos Espanhol. No biênio 1935 e 1936, o comércio de café entre os dois países necessita ser analisado sobre dois prismas distintos: na sua totalidade e em uma divisão semestral. Em

\footnotetext{
${ }^{178}$ Carta de Francisco Franco a Getúlio Vargas. Salamanca. GVc1936.10.29/1 (Vol. XXIX/44). CPDOC/FGV

${ }^{179}$ Cf. NETO, Lira. Getúlio (1930-1945). Do governo provisório à ditadura do Estado Novo. São Paulo: Cia. das Letras, 2013; SOUZA, Ismara Izepe de. op. cit., 2009.
} 
relação às quantidades anuais embarcadas e na comparação entre o espaço desses dois anos, se registraram quedas de 21,3\% do embarcado para a Espanha, 13,3\% para as Ilhas Canárias e 44,8\% para o Marrocos Espanhol:

\begin{tabular}{|c|c|c|c|c|c|c|}
\hline \multicolumn{7}{|c|}{$\begin{array}{r}2.7 \text { - Exportação de Café para áreas sob controle d } \\
\text { (Em sacas de } 60 \mathrm{~kg} \text { ) }\end{array}$} \\
\hline \multirow[t]{2}{*}{ Ano } & \multicolumn{3}{|c|}{1935} & \multicolumn{3}{|c|}{1936} \\
\hline & $\underline{1^{\circ} \text { Sem. }}$. & $\underline{2^{\circ} \text { Sem. }}$. & Total & $\underline{10}$ Sem. & $\underline{2^{\circ} \mathrm{Sem}}$. & Total \\
\hline Espanha $^{180}$ & 33.814 & 36.593 & 70.407 & 51.922 & 3.448 & 55.370 \\
\hline Ilhas Canárias & 7.960 & 9.220 & 17.180 & 11.990 & 2.983 & 14.883 \\
\hline Marrocos Espanhol & 5.782 & 4.794 & 10.576 & 3.571 & 2.265 & 5.836 \\
\hline Total & 47.556 & 50.607 & 98.163 & 67.483 & 8.696 & 76.089 \\
\hline
\end{tabular}

Fontes: BRASIL. DEPARTAMENTO NACIONAL DO CAFÉ. SECÇ̃̃O DE ESTATÍSTICA. Anuário Estatístico do Café, 1939/40. Rio de Janeiro, pp. 378, 390 e 419;

A diferença na quantidade do café exportado, ao tomá-lo de forma semestral, se apresenta de forma bastante acentuada após julho, que pode ser entendida tranquilamente como um efeito do início do conflito intestino espanhol. No entanto, embora nos cinco meses finais de 1936 a quantidade de café exportada para a fração continental da Espanha e para a possessão espanhola na região marroquina terem cessado, ainda se mantém um diminuto fluxo para as Ilhas Canárias:

\begin{tabular}{|l|c|c|c|}
\hline \multicolumn{4}{|c|}{2.8 - Variação mensal de exportação de Café, 1936 } \\
(Em sacas de 60 kg) \\
\hline & Espanha & Ilhas Canárias & Marrocos \\
\hline Janeiro & 12.729 & 2.000 & 363 \\
\hline Fevereiro & 7.530 & 740 & 250 \\
\hline Março & 11.951 & 3.950 & 425 \\
\hline Abril & 9.222 & 1.810 & 465 \\
\hline Maio & 5.944 & 1.480 & 1.378 \\
\hline Junho & 4.546 & 2.010 & 690 \\
\hline Sub-total 1 ${ }^{\text {. }}$. Sem. & $\mathbf{5 1 . 9 2 2}$ & $\mathbf{1 1 . 9 9 0}$ & $\mathbf{3 . 5 7 1}$ \\
\hline Julho & 3.448 & 1.295 & 2.265 \\
\hline Agosto & - & 790 & - \\
\hline Setembro & - & - & - \\
\hline Outubro & - & - & - \\
\hline Novembro & - & 683 & - \\
\hline Dezembro & - & 215 & - \\
\hline Sub-Total 2 ${ }^{\boldsymbol{o}}$. Sem. & $\mathbf{3 . 4 4 8}$ & $\mathbf{2 . 9 8 3}$ & $\mathbf{2 . 2 6 5}$ \\
\hline Total: Ano & $\mathbf{5 5 . 3 7 0}$ & $\mathbf{1 4 . 9 7 3}$ & $\mathbf{5 . 8 3 6}$ \\
\hline Fontes: BRASIL. DEPARTAMENTO NACIONAL DO CAFÉ. SECÇÃO DE ESTATÍSTICA. \\
Anuário Estatistico do Café, 1939/40. Rio de Janeiro, pp. 378, 390 e 419.
\end{tabular}

${ }^{180}$ Porção territorial na Península Ibérica. 
De acordo com os registros do Departamento Nacional do Café, o total de 2.983 sacas embarcadas corresponderam a $24,8 \%$ da variação anual que chegou às Ilhas Canárias. A quantidade apontada se destacou ainda mais, se levado em consideração que não houve, como ressaltamos anteriormente, embarques para a fração continental do Estado espanhol e para a sua possessão marroquina. Dessa forma, por um lado, não foi possível localizar as datas de embarques para o mês de julho e se foram realizadas antes da sublevação; mas, por outro, não resta dúvida que houve o embarque deliberado, para regiões sob o controle do exército sublevado, de 790 sacas de café em agosto, 683 em novembro e mais 215 em dezembro, ou seja, mais de $50 \%$ (1.688 sacas) no período.

A hipótese que temos sobre o recebimento de café por Franco, se refere aos embarques de agosto, pois se for levado em conta o tempo de navegação marítima, a chegada das sacas de café e a elaboração de uma resposta por parte do comando dos sublevados, se enquadraria o envio de uma comunicação datada de 29 de outubro de 1936.

Ademais, existem dois outros fatores: de que o próprio destino desses produtos eram as Ilhas Canárias, um dos focos iniciais da sublevação e cuja guarnição estava sob o controle de Franco; e, com segundo fator, a própria composição dos aparatos paraestatais criados pelos militares.

Como apresentamos no Capítulo 1, a Junta de Defensa Nacional, primeira estrutura provisória do comando sublevado, estava entre julho e começo de outubro de 1936 sob o controle do General Miguel Cabanellas Ferrer. Naquele momento, embora Franco fosse um dos principais membros da Junta, não é viável situá-lo como um dos responsáveis pela captação de ajuda externa. Somente em fins de setembro, com a sua elevação à Generalisímo, que um maior controle do Estado lhe foi atribuído, assim, é possível presumir que um envio específico que chegou às Ilhas Canárias, tornou-se, pelas próprias circunstâncias da elevação de Francisco Franco à cabeça do movimento, em um envio para toda a zona sublevada, o que pode ser atestado pela carta enviada a Getúlio Vargas nos últimos dias de outubro de 1936. No entanto, ainda restam dúvidas sobre a origem do envio das sacas 790 sacas de café. Ao tomarmos em conjunto as circunstâncias dos debates no interior do Itamaraty com o MRE, os registros do próprio Getúlio e a documentação republicana ou dos rebelados, não existem quaisquer referências que o tal embarque tenha sido deliberado pelo próprio governo.

No entanto, como pode ser observado na Tabela 2.8, ainda em 1936 houve uma lenta retomada do comércio cafeeiro. As exportações foram destinadas aos portos das Ilhas Canárias. Assim, o governo Vargas permitiu, ou fez "vistas grossas", ao embarque de sacas para uma 
região na qual o controle dos sublevados era público e notório. Embora de forma ínfima, se comparada com a quantidade global comercializada pelos produtores brasileiros, 898 sacas em novembro e dezembro de 1936, no primeiro semestre de 1937, houve um grande aumento na quantidade exportada se comparada com o período anterior.

\begin{tabular}{|l|c|c|c|}
\hline \multicolumn{4}{|c|}{2.9 - Variação mensal de exportação de Café, 1937} \\
(Em sacas de 60 kg)
\end{tabular}

Fontes: BRASIL. DEPARTAMENTO NACIONAL DO CAFÉ. SECÇÃO DE ESTATÍSTICA. Anuário Estatístico do Café, 1939/40. Rio de Janeiro, 1941, pp. 378, 390 e 419.

O envio de café para o Estado espanhol, sobretudo para as regiões controladas pelos sublevados, continuou no decorrer do primeiro ano do conflito. Assim, se de alguma forma se poderia supor que os primeiros embarques "caíram em mãos indevidas", o mesmo não pode ser dito daqueles realizados entre agosto de 1936 e julho de 1937.

No decorrer desse tempo, foram embarcados 639.300 quilos de café para o território espanhol continental, as Canárias e o Marrocos Espanhol: 


\begin{tabular}{|c|c|c|c|c|c|c|c|c|}
\hline \multicolumn{7}{|c|}{ 2.10 - Embarques de Café: Brasil-Espanha entre julho de 1936 e junho de 1937 } \\
(Em sacas de 60 kg)
\end{tabular}

Fontes: BRASIL. DEPARTAMENTO NACIONAL DO CAFÉ. SECÇÃO DE ESTATÍSTICA. Anuário Estatístico do Café, 1939/40. Rio de Janeiro, 1941.

A Tabela 2.10 apresenta duas situações bastante claras a respeito do embarque de café no primeiro ano da Guerra Civil. (1) Os embarques destinaram-se às regiões que ainda estavam sob controle republicano e, (2) que os embarques originados no Rio de Janeiro destinaram-se à região sublevada.

No primeiro caso, esse fenômeno pode ser associado diretamente ao fato de que a maioria da colônia de origem espanhola que trabalhava na região portuária de Santos vinculavase, de uma forma ou de outra, ao governo legalista. Em relação ao porto carioca, inferimos que houve permissividade ou incentivo para que fossem direcionados embarques aos locais onde a 
sublevação se havia iniciado e que estavam mais afastados da região continental, que estava cercada por via marítima.

Um outro percurso adotado para o envio de café foi por meio de Portugal, ao menos em embarques em dezembro de 1936 e, posteriormente, nas negociações de 1937 e $1938 .{ }^{181} \mathrm{O}$ caminho português possibilitava, inclusive, escamotear os embarques e evitar represálias dos trabalhadores portuários que apoiavam a Segunda República.

Um embarque de 5.000 sacas de café foi apontado pelo presidente da Comisión Nacionalista Española como tendo sido enviado em 30 de dezembro de 1936. E, na mesma comunicação, reforça que já haviam sido realizados embarques anteriores. De acordo com Victor Fernández Alonso, membro da Comisión, em comunicação com Francisco Serrat y Bonastre, secretário de Relações Exteriores da Junta de Defensa:

(...) juntos a diversos políticos e do Departamento Nacional de Café deste país, conseguimos o segundo donativo de 5.000 sacas de café deste Governo, assim como do frete nos vapores do Lloyd Brasileiro, sendo embarcada tal mercadoria no vapor Santos que saiu deste porto no dia 30 de dezembro último. (...) conseguimos que este Governo abrisse mãos dos impostos que este produto possui e que no presente embarque se elevavam a mais de $200.000 \$ 000 . .^{182}$

E ressalta que, em fevereiro de 1937, serão realizados mais embarques:

Temos a satisfação de adiantar a V. Ex. que dentro de 10 ou 15 dias /.../ embarcaremos outras 5.000 sacas de café livre de todos os impostos. ${ }^{183}$

Esses embarques, segundo pode-se inferir a partir do conteúdo da carta, foram intermediados pela Junta De Representación del Estado Español, capitaneada por Mariano Amoedo ${ }^{184}$ em Lisboa. Esse elemento sublevado surgiu como o primeiro intermediário entre os órgãos sublevados do Brasil e de Portugal para o envio de mercadorias para os militares espanhóis. A conexão portuguesa ganha mais força como via de chegada de café e outras

\footnotetext{
${ }^{181}$ A abordagem sobre as negociações secretas e os embarques está no Capítulo 3.

182 Carta de Victor Fernández Alonso, da Comisión Nacionalista Española (Rio de Janeiro), al Secretário de Relaciones Exteriores de la Junta Técnica de Defensa, Francisco Serrat y Bonastre (Salamanca). 28/01/1937. AGA ${ }^{183}$ Ibidem.

${ }^{184}$ Mariano Amoedo foi membro do corpo diplomático espanhol em solo português. Com as fragmentações dos diplomatas e os respectivos posicionamentos junto ao governo republicano ou a Burgos, ele se alinhou a estes últimos. Inclusive foi o responsável por receber doações materiais e em moeda desde o Brasil e repassá-las aos militares. Cf. Carta de Victor Fernández Alonso, da Comisión Nacionalista Española (Rio de Janeiro), al Secretário de Relaciones Exteriores de la Junta Técnica de Defensa, Francisco Serrat y Bonastre (Salamanca). 28/01/1937. AGA.
} 
mercadorias, quando na própria carta, se reconheceu que o novo representante dos negócios de Burgos em Lisboa seria o fundador da CEDA:

Também temos a honra e por em conhecimento de V. Ex. que recebemos telegrama de Lisboa nos comunicando nome de Senhor Gil-Robles para próximos envios. ${ }^{185}$

A correspondência entre a Comisión e Salamanca mostra agudeza em suas afirmações, com a participação de um notório membro do conservadorismo de tendência fascista, como era o caso de José Maria Gil-Robles. Mas outros vestígios desses embarques também emergem e permitem uma maior assertividade nesses embarques via Portugal e na remessa de divisas direcionadas à zona sublevada. Dois dias após acusar o recebimento do telegrama que instituía Gil-Robles em Lisboa como representante dos militares revoltosos de 17 de julho de 1936, o novo intermediário já foi citado como destinatário de doações oriundas desde o Brasil:

Temos a honra de comunicar a V. Ex. que nesta data e em nome de Don José María Gil-Robles, Lisboa, remetemos cheque n: 552.957 no valor de SEIS MIL SETESCENTOS E ONZE (6.711) escudos, a cargo do Banco Espirito Santo de tal cidade e que constituem o quarto envio da Comisión Nacionalista Española de Manaus, Estado do Amazonas a esse governo e resultado das subscrições ali aberta entre os aderidos da colônia espanhola e os simpatizantes brasileiros e estrangeiros da causa Nacionalista. ${ }^{186}$

Ao tomarmos os embarques de café para Portugal nos lapsos temporais dos contatos entre Fernandéz Alonso e Serrat Bonastre temos o seguinte panorama:

185 Carta de Victor Fernández Alonso, da Comisión Nacionalista Española (Rio de Janeiro), al Secretário de Relaciones Exteriores de la Junta Técnica de Defensa, Francisco Serrat y Bonastre (Salamanca). 28/01/1937. AGA 186 Carta de Victor Fernández Alonso, da Comisión Nacionalista Española (Rio de Janeiro), al Secretário de Relaciones Exteriores de la Junta Técnica de Defensa, Francisco Serrat y Bonastre (Salamanca). 30/01/1937. AGA 


\begin{tabular}{|c|c|c|}
\hline \multicolumn{3}{|c|}{$\begin{array}{c}2.11 \text { - Variações mensais de exportação de Café para Portugal, } \\
1 \text { 1936-1937 (Em sacas de } 60 \mathrm{~kg} \text { ) }\end{array}$} \\
\hline & 1936 & 1937 \\
\hline Janeiro & 1.025 & 2.867 \\
\hline Fevereiro & 975 & 2.800 \\
\hline Março & 1.204 & 3.071 \\
\hline Abril & 3.111 & 2.252 \\
\hline Maio & 2.125 & 30 \\
\hline Junho & 700 & 3.408 \\
\hline Sub-total $1^{o}$. Sem. & 9.140 & 14.428 \\
\hline Julho & 2.596 & 815 \\
\hline Agosto & 2.030 & 2.550 \\
\hline Setembro & 1.850 & 551 \\
\hline Outubro & 4.079 & 3.218 \\
\hline Novembro & 7.942 & 3.675 \\
\hline Dezembro & 9.698 & 915 \\
\hline Sub-Total $2^{o}$. Sem. & 28.195 & 11.724 \\
\hline Total: Ano & $\mathbf{3 7 . 3 3 5}$ & 26.152 \\
\hline
\end{tabular}

Ao cotejar as afirmações contidas na correspondência anteriormente citada, percebe-se que nos meses de outubro e dezembro de 1936 houve um aumento que duplicou, ou mesmo triplicou, a média dos meses anteriores. E se tomarmos o mês de dezembro, a marca de 9.868 sacas apresentava-se de forma desproporcional, com uma quantidade muito acima das médias até setembro daquele ano, cujo pico havia sido alcançado ainda em abril, com 3.111 sacas. Nesse sentido é o abrupto crescimento do café exportado a Portugal que se relaciona diretamente com os envios da Comisión. E no mesmo diapasão as amplas quantidades, se também comparadas com os períodos anteriores, de 7.942 sacas do período de novembro de 1936.

Além do café, também é possível iluminar o caso do envio de açúcar, como igualmente havia sido exposto no telegrama de agradecimento de Franco. ${ }^{187}$ De acordo com a posterior correspondência de Julián Chacel, a doação de açúcar foi feita por meio de outro órgão do governo Vargas, o Instituto Nacional do Açúcar e do Álcool (INAA), que desde Pernambuco havia efetuado o embarque. A remessa havia sido organizada, em conluio com o INAA, por meio do desertor Luis Perez, antigo Cônsul republicano em Recife:

187 Carta de Francisco Franco a Getúlio Vargas. Salamanca. GVc1936.10.29/1 (Vol. XXIX/44). CPDOC/FGV 
(...) segundo me comunica o Sr. D. Luis Perez, de Pernambuco, compatriota que ali encarreguei do embarque dos 2.000 sacos de açúcar doados pelo Instituto do Açucar e do Álcool, para os exércitos nacionais, enviaram ao Sr. Victor Fernandez, Presidente da Comisión Nacionalista Española do Rio, a quantidade de 6:007\$700 réis, que com $25 \$ 800$ réis de gastos de envio forma os 6:033\$500 réis que ficaram pendentes de devolução. ${ }^{188}$

E, ressaltou ainda que haviam sido enviados mais sacas de café ao final de fevereiro de 1937. Ao citar o embarque dos últimos dias de fevereiro, incluiu como um dos principais elos políticos para que fosse possível o desenrolar da conexão entre o governo brasileiro e os sublevados espanhóis, o deputado Adalberto Correa, presidente da Comissão Nacional de Repressão ao Comunismo.

A revelação, por parte de Chacel, dos envolvidos nas negociatas de café ocorreu justamente no instante em que ele estava sendo afastado do comando da Comisión Nacionalista Española. Assim, essas considerações aparecem como uma prestação de contas finais junto aos militares no território espanhol:

Para dar por terminada minha intervenção nas remessas em questão, estou à espera do certificado da chegada a Lisboa e destino dos 2.000 sacos de café remetidos em fins de fevereiro. Esse certificado já comuniquei a V. Ex. que o solicitava a requerimento do Sr. Presidente da Comissão Nacional (brasileira) de Repressão ao Comunismo, Sr. Adalberto Correa. ${ }^{189}$

Uma condição que nos parece extremamente pertinente, e é citada por Chacel, é a de que Correa fazia questão de se desvincular e, consequentemente o governo Vargas, de quaisquer ligações com os envios que chegariam aos militares por meio de Lisboa:

Esse senhor tendo se responsabilizado pela entrega a mim pela entrega da mercadoria, único espanhol que interviu na recepção e remessa da mercadoria, entende indispensável para ele ter este certificado, que junto com o enviado pelo Sr. Erices em 6 de março constituirão prova da intervenção da Comisión brasileira e de que as quantidades recebidas aqui e as chegadas a Lisboa são exatamente iguais. ${ }^{190}$

É conclusivo que uma ampla parcela da documentação dos representantes da Junta Nacionalista Española e da Comisión Nacionalista Española afirmassem e voltassem a

\footnotetext{
${ }^{188}$ Carta de Julián Chacel al Secretario de Relaciones Exteriores del gobierno del Estado Español (Salamanca), Sr. D. Francisco Serrat. 20/04/1937. AGA

189 Ibidem.

190 Ibidem.
} 
ressaltar o envio de café por meio de Portugal e com confirmações desde Burgos e Salamanca. No entanto, ao analisarmos os dados de importação e exportação elaborados pelo governo português, se apresentava o seguinte cenário:

\begin{tabular}{|c|c|c|}
\hline \multicolumn{3}{|c|}{$\mathbf{2 . 1 2}$ - Importações e exportações de Café por Portugal, 1936-1937 (Em kg) } \\
\hline & 1936 & 1937 \\
\hline $\begin{array}{c}\text { Importação anual de café do } \\
\text { Brasil para consumo }\end{array}$ & 1.442 .858 & 1.397 .706 \\
\hline $\begin{array}{c}\text { Exportação nacional ou } \\
\text { nacionalizada para a Espanha }\end{array}$ & 1.415 .258 & 857.104 \\
\hline $\begin{array}{c}\text { Reexportação de café para a } \\
\text { Espanha }\end{array}$ & 1.486 .597 (São Tomé \& Príncipe) & ---------------------- \\
\hline $\begin{array}{c}\text { Baldeação e trânsito internacional } \\
\text { para a Espanha }\end{array}$ & 29.228 (Angola) & 128.229 (Angola) \\
\hline $\begin{array}{c}\text { Trânsito Indireto para a Espanha } \\
\text { Indang }\end{array}$ & - & $\begin{array}{c}279.236 \text { (São Tomé) } \\
5.869 .317 \text { (Angola) } \\
5.063 \text { (Moçambique) }\end{array}$ \\
\hline
\end{tabular}

Fontes: PORTUGAL. INSTITUTO NACIONAL DE ESTATÍSTICA. Estatística Comercial. Ano de 1936. Importações e Exportações por classe e artigos da pauta. Lisboa: Imprensa Nacional, vol. 1, 1937, pp. 68, 158, 198, 225; PORTUGAL. INSTITUTO NACIONAL DE ESTATÍSTICA. Estatística Comercial. Ano de 1937. Importações e Exportações por classe e artigos da pauta. Lisboa: Imprensa Nacional, vol. 1, 1938, pp. 69, 180, 234. (Adaptada pelo autor)

As estatísticas oficiais portuguesas não apresentavam nenhum dado de que o café enviado desde o Rio de Janeiro possuísse alguma programação de que seria nacionalizado, ou se em algum porto haveria uma baldeação para o destino final, ou seja, a zona sublevada espanhola. E, como estava destinado especificamente a uma pessoa física, isto é, Mariano Amoedo, então principal contato da Junta portuguesa, esse café esteve somado ao total de importação para o consumo e, por hipótese, pode ter sido posteriormente transportado por meio terrestre. ${ }^{192}$

E, enquanto os representantes de Burgos no Brasil traçavam seu apoio e enviavam mercadorias, divisas e outros tipos de doações aos sublevados, o governo dos Estados Unidos já estava envolto nas consequências do conflito espanhol tanto internamente, como em âmbito continental.

\footnotetext{
${ }^{191}$ Decidimos manter discriminado como estão os dados originais no que concerne as modalidades "Trânsito Indireto" e "Reexportação de café para a Espanha". Essa decisão foi tomada porque os próprios anuários não abordam se houve alguma alteração na quantificação dos respectivos dados.

${ }^{192}$ Intenciona-se em um futuro próximo e como desdobramento desta pesquisa tentar traçar o caminho pelo qual este café chegou à zona rebelde.
} 


\subsection{Estados Unidos: posicionamento e propostas continentais.}

É possível pontuar as ações da política externa dos Estados Unidos, entre o fim do século XIX e a década de 1930, em três eixos essenciais.

Primeiramente, o período do "corolário", caracterizado no decorrer da presidência de Theodore Roosevelt por um conjunto de intervencionismos que combinavam elementos militares, políticos e econômicos. Os casos mais emblemáticos foram a intervenção em Cuba, após o processo de independência da Espanha e a implementação na Constituição da Emenda Platt, em 1898. Um segundo, que se construiu ao final da Grande Guerra e que derivava das propostas de Woodrow Wilson, que levou o país a um isolacionismo internacional e que somente a partir do governo do presidente Herbert Hoover, em fins da década de 1920, apresentou tímidos avanços a respeito de uma presença mais ampla no cenário internacional. ${ }^{193}$ E o terceiro eixo, com a ascensão de Franklin Delano Roosevelt à presidência que, se por um lado, manteve algumas características do isolamento norte-americano, por outro, propôs ou pôs em prática atitudes que permitiram que os Estados Unidos tivessem uma presença mais efetiva no cenário internacional e, principalmente, latino-americano.

Em relação a esse último período, que corresponde diretamente ao recorte da nossa pesquisa, construiu-se uma indissociabilidade entre as propostas de política interna e externa nos Estados Unidos. Ou seja, tanto a política de recuperação econômica e social, o New Deal, bem como a Good Neighbor's Policy com seus princípios pan-americanistas, apresentaram um cruzamento que desejava impedir a crescente influência europeia no cenário latino-americano, principalmente de países como a Itália e a Alemanha. E que, consequentemente, pavimentaria uma supremacia hemisférica com o estímulo de estabilidades politicas nos países latinoamericanos, que seriam usados como mercados de consumo no interior da estratégia de Washington para a revitalização econômica.

Essa intersecção apresentou-se claramente no "Fireside Chat", no qual Roosevelt apresentou o New Deal:

Lado a lado com a nossa situação interna que é claro, nosso primeiro interesse, está a situação mundial, e quero enfatizar a vocês que a situação interna é inevitável e profundamente amarrada com as condições de todas as outras nações do mundo. Em outras palavras, nós podemos conseguir, provavelmente, uma justa medida de prosperidade para reverter aos Estados Unidos, mas isso não será permanente ao menos que consigamos uma volta à prosperidade ao redor do mundo.

\footnotetext{
193 Desde o século XIX, havia no interior das esferas executivas e legislativas uma série de debates em torno das propostas internacionalistas e isolacionistas da política externa dos Estados Unidos.
} 
Nas conferências que tivemos e temos com os líderes de outras nações, estamos em busca de quatro grandes objetivos: primeiro, uma redução geral de armamentos e que por meio dele, o fim do medo de invasão e de ataque armado, e, ao mesmo tempo, a redução no custo de armamento, em vista de ajudar no equilíbrio de orçamento do governo e diminuição de impostos; segundo, um corte nas barreiras de comércio, em vista de reiniciar o fluxo de comércio das colheitas e bens entre as nações; terceiro, a criação de uma estabilização de divisas, de forma que o mercado possa fazer contratos futuros; quarto, o restabelecimento de relações amigáveis e de maior confiança entre todas as Nações. ${ }^{194}$

A congruência das propostas presentes na apresentação do New Deal, com o papel que a política externa dos Estados Unidos teria a partir de 1933, consolidou-se com a $7^{\text {a }}$ Conferência Internacional dos Estados Americanos, ocorrida em dezembro daquele ano em Montevidéu. Um dos principais membros e arquitetos da política externa norte-americana, o então Secretário de Estado Cordell Hull, participou in loco de uma agenda cujo principal conteúdo foram as intervenções político-econômico-militares impetradas pelas administrações anteriores do executivo norte-americano, que ainda ressoavam no continente, principalmente na América Central e no Caribe. ${ }^{195}$ Assim, ao menos oficialmente, em 1934, Roosevelt abandonou de forma normativa a Emenda Platt e retirou os fuzileiros navais da sua ocupação no Haiti.

As discussões no decorrer da Conferência tiveram como destaque o debate acerca do direito de intervenção em assuntos internos ou externos de outro país. A sua justificativa sustentava-se no discurso de que em certas ocasiões essas intervenções eram necessárias. Com o fim do encontro, em 23 de dezembro de 1933, concertou-se que o artigo $8^{\circ}$ traria essa possibilidade de forma reservada. $\mathrm{O}$ discurso de encerramento da participação norte-americana afirmava que,

(...) de todo coração que com o fim do conflito armado como um instrumento de resolver disputas internacionais vai perder seu último suporte neste hemisfério. ${ }^{196}$

A promessa de Cordell Hull em Montevidéu transformou-se em um dos primeiros movimentos perante os outros países latino-americanos para desvincular a sua imagem belicista

\footnotetext{
${ }^{194}$ Franklin D. Roosevelt's Fireside Chats. "Outlining the New Deal Program” de 07 de maio de 1933. In: Franklin D. Roosevelt Presidential Digital Archives. Disponível em: 〈www.fdrlibrary.marist.edu〉. Acesso em: 23 jan. 2009.

195 Cf. SCHOULTZ, Lars. Beneath the United States: a history of U.S. policy toward Latin America. London/Cambridge: Harvard University Press, 1999.

196 U.S., Department of State, Publication 1983, Peace and War: United States Foreign Policy, 1931-1941. Washington, D.C.: Government Printing Office, 1943, p. 197.
} 
no continente. E, na mesma fala, o Secretário de Estado reafirmou o caráter de integração do New Deal, com as propostas da divulgada "Política de Boa Vizinhança":

Os Estados Unidos estão determinados de que sua nova política do New Deal - de liberalismo iluminista - poderá ter completo efeito e poderá ser reconhecido em sua total importância pelos seus vizinhos. O povo de meu país sente imensamente que o tão chamado direito à conquista deve ser banido para sempre desse hemisfério e que todos devem evitar e rejeitar esse direito a si mesmos. O New Deal claramente seria um esforço vazio se isso não tivesse significado. ${ }^{197}$

Ato contínuo da proposta de "pacificação" nas Américas e do seu isolamento em relação aos conflitos internacionais, a administração Roosevelt implementou uma série de instrumentos que aumentavam o grau de isolamento da participação norte-americana na seara internacional.

Esse carácter foi reforçado com a proclamação, por parte do Congresso dos Estados Unidos, de um Ato de Neutralidade em 1935 e outro, complementar em 1936.

A proclamação do Ato de Neutralidade, em 31 de agosto de 1935, pouco antes da invasão Abissínia pelas forças italianas, limitou as margens de manobras para a política externa de Roosevelt. Como está lavrado no próprio Ato, a partir do momento em que um estado de guerra fosse declarado entre duas nações, o Presidente instituiria um embargo de armas e poderia proibir as viagens de norte-americanos nos navios dos países beligerantes, exceto se fosse pelo próprio risco dos viajantes. Mesmo a sanção do Ato foi firmada com relutância pelo presidente dos Estados Unidos, pois segundo o próprio, a lei, ao invés de manter o país fora de qualquer conflito, pelo contrário, poderia forçá-lo, em alguma medida, a ser um partícipe. ${ }^{198}$

$\mathrm{Na}$ esteira do Ato de 1935, em fevereiro do ano seguinte, foi promulgado o Ato Complementar que envolvia a proibição de empréstimos a países em conflito.

Em torno das relações entre Estados Unidos e Espanha, no decorrer da década de 1930, ainda havia o distanciamento originado desde da Guerra Hispano-Americana em 1898.

O aumento da atenção dos Estados Unidos pela Espanha voltou a ocorrer a partir de 1934, quando da ascensão dos grupos conservadores e reacionários ao poder na Segunda República espanhola. Esse interesse foi alimentado pela assinatura de acordos de assistência do novo governo com a Alemanha e a Itália. Em grande medida, o interesse emergiu pela

${ }^{197}$ U.S., Department of State, Publication 1983, Peace and War: United States Foreign Policy, 1931-1941. Washington, D.C.: Government Printing Office, 1943, p. 198.

${ }^{198}$ FERREL, Robert H. O Preço do Isolamento. Diplomacia Americana, 1921-1945. In: LEUCHTENBURG, William (Org.). O Século Inacabado: A América desde 1900. Rio de Janeiro: Zahar Editores, 1976, p. 522. 
possibilidade de Alemanha e Itália utilizarem os portos espanhóis do Mediterrâneo para abastecimento de produtos e de tropas.

Em janeiro de 1936, o governo Roosevelt já estava ciente do movimento de tropas alemãs e italianas na região de Cádiz. Devido à solicitação ao Departamento de Estado, o Cônsul norte-americano enviou um telegrama à embaixada americana em St. Jean de Luz em que afirmava:

Em requisição ao Departamento a respeito de informação referente ao número de soldados estrangeiros na Espanha, segue-se o seguinte: cinco mil alemães e 8 mil italianos chegaram até o momento via Cádiz. ${ }^{199}$

Ao iniciar a Guerra Civil, os Estados Unidos estavam em período eleitoral. No entanto, as preocupações dos candidatos, principalmente de Roosevelt, residiam mais na condição interna dos Estados Unidos do que em sua política exterior. Em grande parte, essa ausência de preocupação associava-se diretamente ao isolacionismo que ambos os partidos compartilhavam. No entanto, o fato de se declarar neutro na contenda espanhola, foi favorável para os rebelados comandados por Franco. Pois, enquanto os nacionalistas recebiam armas de seus aliados germano-italianos, o governo legalista republicano ficou de mãos atadas sob o jugo da comunidade internacional.

A percepção do acirramento da polarização política no interior da Espanha já fazia parte das análises por parte do governo norte-americano. Nos dias anteriores ao estouro do conflito no Marrocos, o Embaixador Claude G. Bowers já expunha os embates e o crescimento do desequilíbrio causado pela vitória da Frente Popular. A situação crítica em Madri já havia feito a própria embaixada ter sido removida para San Sebastián. Em comunicação com Cordell Hull, Bower afirma que,

Por algum tempo o governo tem combatido sem destacado sucesso os métodos de violência pessoal que os elementos extremistas da esquerda e direita tem realizado. Esses métodos têm sido particularmente perceptíveis na conexão com as disputas trabalhistas, nas quais elementos irresponsáveis tem se esforçado pelo terrorismo e intimidação a fomentar desordem e evitar acordos em greves; e, ocasionalmente, em atos pessoais de violência dirigidos contra pessoas de proeminência política e filiações tanto da esquerda quanto da direita. ${ }^{200}$

199 "Telegram from Charles A. Bay to American Ambassador, St. Jean de Luz, January 9, 1936" In: General Correspondence of the Department of State. RG 59, NARA/II.

${ }^{200}$ From the Ambassador in Spain (Bowers) to Secretary of State. "Cable no. 1183. San Sebastián, July, 11, 1936. In: UNITED STATES. Foreign Relations of the United States. Europe. 1936. Washington, D.C.: Government Printing Office, vol. II, 1954, p. 437. 
Se os confrontos entre conservadores e partidos de esquerda eram notórios, a situação entre comunistas e anarquistas não era distinta. O consulado americano em Sevilha enviou um relatório em que apresentou alguns desses embates que adquiriram contornos de uma vendetta:

Atirador anarquista visitou o quartel-general dos comunistas e com uma metralhadora assassinou todos os ocupantes ${ }^{201}$

Além de tentar manter os Estados Unidos à parte de um envolvimento direto na Espanha, a decisão pelo embargo também atingiu as disputas internas pelo tipo de política externa estadunidense, ou seja, a disputa entre o isolacionismo vigente ou a participação, ao menos indireta, na dinâmica conflituosa do continente europeu nos anos de 1930. O caminho escolhido por Roosevelt e o Departamento de Estado tornou-se aceitável, pois:

Os isolacionistas a aprovaram porque nos mantinha fora do conflito. Os internacionalistas aprovavam porque estávamos cooperando com a Inglaterra e com a França. ${ }^{202}$

No entanto, essa tomada de decisão não foi aprovada no decorrer de todo o conflito. Embora, em princípio tenha sido amplamente aceita, no decorrer dos três anos da Guerra Civil Espanhola, houve o crescimento de uma oposição à neutralidade e ao embargo impetrado e mesmo ao seu final. Com o advento da Segunda Guerra Mundial, tornou-se notória a associação entre aqueles que seriam os vencedores e a Alemanha nazista. De acordo com as impressões de Hull, em suas memórias:

Do tempo que a promulgamos em agosto de 1936, não a modificamos até quando a Guerra Espanhola chegou ao fim, em março de 1939. Enquanto o tempo passou, essa política sofreu mais e mais sob o ataque de certos elementos desse governo. Alguns daqueles mais extremos ainda não perdoaram a administração Roosevelt pela sua recusa de ter se envolvido no conflito espanhol ajudando aquele governo na perigosa dimensão que eles pediam. $^{203}$

A conduta de neutralidade permitiu que no decorrer do conflito, houvesse duas representações políticas da Espanha nos Estados Unidos. O governo republicano estava

\footnotetext{
${ }^{201}$ Political Report: the Political Situation in Seville. From Consulate in Seville (Charles A. Bay) to Embassy in San Sebastián, July 18, 1936. General Correspondence of the The Department of State, RG 59. NARA/II.

${ }^{202}$ HULL, Cordell. The Memoirs of Cordell Hull. New York: Ed. Mcmillan, 1940, vol. I, p. 479.

${ }^{203}$ Ibidem. p. 481.
} 
representado pelo intelectual Fernando de los Ríos, enquanto que Franco havia enviado Juan F. de Cárdenas, um dos diplomatas partidários do levante militar e que no momento do início do conflito estava em Paris. Embora não estivesse em uma missão ou representação oficial em Washington, Cárdenas visitava regularmente o Departamento de Estado chefiado pelo subsecretário James C. Dunn, que era partidário do levante militar feito por Franco. Mas mesmo com a presença constante do enviado franquista, os Estados Unidos mantiveram suas relações diplomáticas com o governo de Madri até o fim da Guerra. ${ }^{204}$

Mesmo com a instituição do "embargo moral", nos primeiros anos da Guerra e mesmo a partir de 1937 com a proposta mais rigorosa do Ato de Neutralidade daquele ano, o fornecimento de alguns insumos não foram interrompidos. Principalmente aqueles que eram derivados do petróleo e o fornecimento de créditos no mercado internacional. O principal artifício para os contatos comerciais com os insurretos, foi a utilização das filiais da Standard Oil, da Vacuum Oil Company, em Tanger, e da Texas Oil Company (Texaco), que abasteceram durante toda a Guerra a zona nacionalista. Uma das justificativas para a venda somente aos rebeldes, era que os portos republicanos não eram seguros, enquanto que os dos rebelados estavam abertos e possuíam segurança suficiente. Segundo Herbert Feiss, assessor econômico na Embaixada norte-americana, entre 1936 e 1939 as forças de Franco receberam 1.866.000 toneladas de petróleo e 12.800 caminhões de empresas norte-americanas. ${ }^{205}$

Ademais, o ambiente interno nos Estados Unidos estimulava essa ajuda indireta para alimentação aos rebelados franquistas. Em grande parte, a associação feita pela Cúria norteamericana de que o governo republicano representava uma força ateia e "comunizante" ou ainda, na melhor das hipóteses, um elemento fraco da democracia que estaria sob o controle de Moscou e do Partido Comunista Espanhol.

Com o desenrolar das três primeiras semanas de conflito, os relatórios das representações diplomáticas norte-americanas apresentavam as aceleradas derrotas das tropas leais ao governo da Frente Popular. Em sua maioria, os reports continham três tipos de informações: a dinâmica das resistências que se construíam frente a um exército mais poderoso, as ações tomadas pelas tropas ocupantes, principalmente aquelas que apontavam o fuzilamento de líderes trabalhistas e sindicais e os avanços territoriais dos militares sublevados. Tanto que na Andaluzia,

\footnotetext{
${ }^{204}$ MATTHEWS, Herbert. Metade da Espanha Morreu: uma reavaliação da Guerra Civil Espanhola. Rio de Janeiro: Civilização Brasileira, 1975. p. 184

${ }^{205}$ Ibidem. p. 185
} 
Consolidação de posições militares nessa região quase completa. Com exceção de Málaga, todos os territórios ao sul ad linha de Badajós até Sevilha e de Córdoba à Granada, inclusive, está seguramente no controle dos militares. ${ }^{206}$

No interior das negociações internas quanto a qual posicionamento tomar frente ao conflito, o Departamento de Estado analisava, de forma concomitante, o cenário espanhol e principalmente europeu, pois se as políticas de apaziguamento deveriam fazer efeito na Europa, com a Guerra Civil Espanhola foi afetada a política externa norte-americana:

\begin{abstract}
Enquanto formulávamos e declarávamos nossa política em relação à Guerra Civil Espanhola, era especialmente evidente que desde o início do conflito, a maioria das nações europeias tinha um interesse muito concreto no conflito. Nossos telegramas estavam cheios de mensagens de nossos diplomatas fornecendo as atitudes e prováveis ações desses governos. No decorrer de uma semana após o começo da guerra, era fortemente evidente que as pacíficas nações da Europa, particularmente Grã-Bretanha e França, fariam um grande esforço para limitar o conflito à Espanha. ${ }^{207}$
\end{abstract}

Dentro desse panorama, começou a se delinear os pilares da ação norte-americana em relação à Guerra Civil Espanhola e suas ações junto ao cenário internacional. O primeiro, estava situado na condição dos cidadãos norte-americanos em território espanhol. O segundo, dizia respeito a quais atitudes deveriam ser tomadas em relação aos contatos entre os Estados Unidos e os dois grupos em disputa, com a vinculação e o caráter que os Estados Unidos havia imprimido em sua política internacional desde a ascensão de Roosevelt. E, finalmente, a intersecção desse posicionamento em relação à América Latina e ao Brasil:

Portanto, nas três semanas após a deflagração da Guerra Espanhola, dois fatores eram evidentes para nós. O primeiro, era que os governos britânico e francês, acreditavam que um rígido acordo europeu para se abster de intervir nos assuntos espanhóis era o melhor caminho para evitar a disseminação do conflito. $O$ segundo era a iniciativa de relegar às nações europeias a negociação do problema espanhol. ${ }^{208}$

Em 7 de agosto, o Departamento de Estado enviou um telegrama às suas representações em que discutia o posicionamento que o governo tomaria frente ao desenvolvimento de uma guerra civil na Espanha. Embora os atos de neutralidade de 1933 e 1935 se referissem somente

\footnotetext{
206 "Telegram from Consulate in Seville (Charles A. Bay) to Department of State, no. 3, August 3, 1936. General Correspondence of The Department of State, RG 59. NARA/II.

${ }^{207}$ HULL, Cordell. op. cit., p. 476.

${ }^{208}$ Ibidem. p. 477.
} 
ao conflito entre países, criou-se o "embargo moral", no qual estendia a decisão de não tomar parte de nenhum dos dois lados na Espanha. De acordo com Cordell Hull:

Não tínhamos o direito legal de proibir a exportação de armas para a Espanha, como não tínhamos o direito legal de proibir a exportação de materiais essenciais de guerra, além de armas, para a Itália e Etiópia. Mas poderíamos utilizar a pressão moral do governo para manter os nossos cidadãos fora de envolver a nação nos negócios internos de outra nação e de contribuir para o prolongamento ou disseminação da guerra. ${ }^{209}$

No entanto, mesmo com os apelos governamentais em torno da instituição desse embargo moral, as empresas norte-americanas continuaram a perceber o mercado espanhol como uma área de próspera venda de produtos. E, com a Guerra Civil, emergiu um novo filão de vendas, que era a área bélica. Um dos casos mais emblemáticos em relação à tentativa de venda de materiais militares foi a proposta de venda de aviões da Glenn L. Martin Company. A consulta feita pela empresa ao Departamento de Estado, em 10 de agosto, fez o subsecretário de Estado, William Phillips, a interromper as férias de Hull. A resposta, segundo o mesmo, havia sido definitiva.

(...) parece razoável assumir que a venda de aeronaves, (...), não seguiria o espírito da política de governo. ${ }^{210}$

Essa situação de abastecimento das tropas rebeladas por alemães se manteve mesmo com a assinatura desses últimos ao tratado elaborado pelo Comitê de Não-intervenção. E a própria representação diplomática já apontava aquela que seria a dinâmica comercial-militar entre a Espanha e a Alemanha, ou seja, a troca de material de guerra por matéria-prima e outras riquezas:

Tráfego no porto esteve em seu máximo em relação ao mês devido à presença de numerosos vapores alemães. Material de Guerra é descarregado em uma seção fechada e remota do porto. Exportações em níveis improcedentes. Há uma escassez de moedas de prata e a condição de ter todas faturas em pesetas causa apreensão geral. ${ }^{211}$

\footnotetext{
${ }^{209}$ HULL, Cordell. op. cit., p. 478.

${ }^{210}$ Ibidem.

211 “Telegram from Consulate in Seville (Charles A. Bay) to Departament of State. November 27, 1936. General Correspondence of the The Department of State, RG 59. NARA/II.
} 
Enquanto a Espanha possuía uma quantidade escassa de prata, aumentavam-se os rumores da extração de outros minérios para fornecimento da Alemanha, como no caso do Norte da África:

Existem rumores também de que os alemães exigiram e obtiveram um contrato de trezentos mil toneladas de minério de ferro do Marrocos Espanhol. ${ }^{212}$

Ao final de novembro, algumas semanas antes da Conferência de Buenos Aires, chegaram mais confirmações da presença alemã junto ao círculo de comando dos militares comandados por Franco. A situação de despreparo militar desse último é apontada, pelo próprio governo americano, mas também por militares alemães. E que o comando das estratégias militares deveria estar sob o controle das tropas hitleristas. A informação, que provém de um correspondente internacional, dá conta de que:

(...) Capitão Roland Strunk disse ser o agente-chefe de Hitler na Espanha. Ele confirma que Franco poderia ter capturado Madrid no primeiro dia e declara que devido à tal situação, ele informou Franco que deve aceitar o comando alemão da campanha também ou a Alemanha iria retirar o seu material. Franco aceitou. ${ }^{213}$

Em 14 de dezembro de 1936 o próprio Charles A. Bay conseguiu novas informações acerca das ações do enviado alemão. Ao repassar tais informações ao consulado norteamericano em Gibraltar, reafirmou a dependência dos militares nacionalistas em relação às forças alemães, pois Strunk teria afirmado que o embate já havia ultrapassado a barreira de um conflito interno e alcançado amplas proporções no cenário internacional:

Do tempo que a promulgamos em agosto de 1936, não a modificamos até quando a Guerra Espanhola chegou ao fim em março de 1939. Enquanto o tempo passou, essa política sofreu mais e mais sob o ataque de certos elementos desse governo. Alguns daqueles mais extremos ainda não perdoaram a administração Roosevelt pela sua recusa de ter se envolvido no conflito espanhol ajudando aquele governo na perigosa dimensão que eles pediam. ${ }^{214}$

\footnotetext{
212 "Telegram from Consulate in Seville (Charles A. Bay) to Departament of State. December 30, 1936. General Correspondence of the The Department of State, RG 59. NARA/II.

213 "Telegram from Consulate in Seville (Charles A. Bay) to Departament of State. Srictly Confidential. November 29, 1936. General Correspondence of the The Department of State, RG 59. NARA/II.

${ }^{214}$ HULL, Cordell. op. cit., p. 481.
} 
Ainda em dezembro de 1936, o princípio não intervencionista dos Estados Unidos foi reforçado com a Declaração de Princípios e Cooperação proclamada na Conferência de Buenos Aires. O documento dispunha sobre a absoluta autonomia jurídica e o respeito de outrem em termos de soberania, com a democracia se estendendo de forma comum a toda América. No entanto, os resultados da reunião na capital argentina repousaram muito mais em um discurso teórico do que passível de ser posto em prática, pois, pelo fato da Declaração ser um instrumento conjunto, ao invés de um tratado, fez com que estivesse revestido de um caráter mais opcional que obrigatório.

Frente a uma situação de instabilidade na Europa, que além da Guerra Civil também comportava o rearmamento alemão e a invasão da Etiópia pelos italianos, a proposta norteamericana ia ao encontro da criação de uma "Doutrina Monroe hemisférica" que, como decisão final, implicaria a consulta, a colaboração e a decisão coletivas, fosse em caso de intervenção militar alienígena à América Latina ou a própria participação dos países em conflitos em outros continentes. A tentativa de impor uma decisão coletiva, por parte dos norte-americanos, naufragou. Quando Hull solicitou nas negociações preliminares da Conferência, a criação de uma Comissão Consultiva Interamericana para monitorar as questões a respeito da paz, ela foi vista como uma tentativa de impor uma política hemisférica que estaria sob o controle dos Estados Unidos. ${ }^{215}$ Com o endurecimento da posição argentina, aprovou-se na declaração final que, em caso de guerra externa, as consultas se restringiriam somente se as nações assim o desejassem. $^{216}$

Todo ato suscetível de distúrbio de paz da América afeta cada um deles, e justifica o início do procedimento de consulta provida pela Convenção pela Manutenção, Preservação e Restabelecimento de Paz, assinado nesta Conferência. ${ }^{217}$

No decorrer dos dois anos seguintes, o posicionamento norte-americano a respeito da influência da Guerra Civil no continente americano se pautou pela abordagem individual entre os países das Américas e a vigilância sobre a interferência de outros países na contenda.

\footnotetext{
215 SCHOULTZ, Lars. op. cit., 2000. p. 355.

216 RAPOPORT, Mario y SPIGUEL, Claudio. Relaciones tumultuosas: Estados Unidos y el primer peronismo. Buenos Aires: Emecé Editores, 2009. p. 23

${ }^{217}$ Declaration of Principles of Inter-American Solidarity and Cooperation, Buenos Aires, December 21, 1936. In: UNITED STATES, Department of State. Peace and War: United States Foreign Policy, 1931-1941 (Washington, D.C.: U.S., Government Printing Office, 1943, p. 352.
} 
Sobre a continuidade do fluxo de armas de origem italiana, o embaixador dos Estados Unidos na Itália afirmou, em janeiro de 1937, que:

(...) os recursos espanhóis de Franco são muito limitados e ele irá requisitar substancial contínua ajuda estrangeira para suprimentos e homens, presumidamente da Itália e Alemanha. Atualmente outras estimativas expõe sua necessidade de no mínimo 20.000 tropas estrangeiras treinadas até mesmo para manter sua presente posição. Também é relatado que Franco tem mostrado perda de comando e sua organização militar é mais ineficiente. Afirmam que os melhores de suas tropas espanholas foram mortas nos dias iniciais da guerra e que Franco não está fazendo esforços para aumentar outros exércitos na Espanha, mas primariamente irá confiar em tropas estrangeiras. ${ }^{218}$

Com o aumento das necessidades das tropas comandadas por Franco, houve a continuidade do fornecimento de tropas e armas italianas, além de acrescentar o próprio efetivo militar dos rebelados. Ainda, da perspectiva das representações dos Estados Unidos, desde Sevilha o cônsul norte-americano comunicou que,

Outro contingente de aproximadamente 4.000 italianos chegaram em Cádiz na última semana, deste modo com um total de aproximadamente 8.000 chegadas ao longo da última quinzena excluída as da Cruz Vermelha (...). Estas forças são em sua maior parte de infantaria e artilheiros e dizem que vem diretamente da Abissínia. Cruzador Baleares navio-irmão do Cruzador Canarias, recentemente lançado, está sendo agora equipado em Cádiz com armas e estará pronto para serviço dentro de uma semana. ${ }^{219}$

Enquanto o Cônsul norte-americano em Sevilha descreve a constante chegada de armamentos e pessoal para apoio dos rebelados na região do Mediterrâneo, o embaixador Phillips, na Itália, analisou uma reunião feita entre o embaixador inglês e o Conde Ciano, então ministro de relações exteriores da Itália fascista:

Ele [Ciano] afirmou que o governo italiano voluntariosamente aceitaria parar com todos os voluntários italianos e retirar aqueles que haviam chegado, se os governos da França, Rússia e Bélgica, que ele descreve como os principais países envolvidos do outro lado, realizassem equivalente ação. Drummond [embaixador inglês na Itália] se impressionou pelo evidente desejo de Ciano tanto quanto possível de evitar maiores complicações europeias e pareceu

\footnotetext{
218 Telegram 852.00/4274. From The Ambassador in Italy (Phillips) to the Secretary of State. 06/01/1937. UNITED STATES OF AMERICA. DEPARTMENT OF STATE. op. cit., 1954, p. 215.

${ }^{219}$ Telegram 852.00/4293. From The Consul at Seville (Bay) to the Secretary of State. 07/01/1937. UNITED STATES OF AMERICA. DEPARTMENT OF STATE. op. cit., p. 216.
} 
especialmente satisfeito de ter assegurado de que este é o mais profundo desejo do Duce. ${ }^{220}$

Em relação à França, no começo de 1937, as suas preocupações centraram-se no contínuo envio de tropas alemãs para ajudar os nacionalistas rebelados. Um dos principais pontos de atenção era o abastecimento de pessoal e insumos no Marrocos Espanhol, que poderia trazer problemas tanto às relações francesas com suas colônias, como ao controle comercial do Mediterrâneo por parte da Inglaterra. Sobre isso, o embaixador norte-americano discutiu os temores franceses e afirmou que:

(...) o governo francês tem temido que de forma camuflada, o envio pelos alemães para reforçar Franco teria enviado tropas para o Marrocos Espanhol e ocupado aquele território. A ocupação alemã do Marrocos Espanhol cortaria as comunicações francesas com as colônias do norte africano; cortaria as comunicações da Inglaterra no Mediterrâneo e que isso seria intolerável para a França ou Inglaterra. ${ }^{221}$

Embora o ministro alemão Neurath negasse sistematicamente o envio de tropas para o Marrocos Espanhol e estimulasse um acordo comercial e financeiro com o governo francês por meio de Schacht, presidente do Reichsbank e ministro da economia do Terceiro Reich, os temores da França não eram infundados. Ainda de acordo com o embaixador americano:

(...) dois dias atrás chegou a informação, que o governo francês havia recebido de seus agentes no Marrocos Espanhol, que 300 soldados alemães haviam desembarcado no Marrocos Espanhol e que contratos haviam sido feitos por agentes alemães no Marrocos Espanhol por alojamentos e suprimentos para 3.000 tropas alemães em Ceuta e vizinhança. Além disso, ao mesmo tempo, François-Poncet em Berlim e o Cônsul francês em Munique informaram o governo francês que tinham tido informação que 3.000 Reichwehr tropas da Bavária estavam para ir para o Marrocos Espanhol para chegar aproximadamente 10 de Janeiro. ${ }^{222}$

Além da associação direta das pretensões "fascistas" espanholas de tomar o controle no interior do país, Roosevelt não possuía uma inclinação de apoio à Segunda República, como os membros do seu gabinete o tinham, como os Secretários do Tesouro e do Interior, respectivamente, Henry Morgenthau e Harold L. Ickes, além da sua esposa Eleanor e de Claude

\footnotetext{
${ }^{220}$ Telegram 852.00/4292. From The Ambassador in Italy (Phillips) to the Secretary of State. 07/01/1937. UNITED STATES OF AMERICA. DEPARTMENT OF STATE. op. cit. p. 216.

${ }^{221}$ Telegram 852.00/42305. From The Ambassador in France (Bullitt) to the Secretary of State. 09/01/1937. UNITED STATES OF AMERICA. DEPARTMENT OF STATE. op. cit., p. 217. ${ }^{222}$ Ibidem.
} 
Bowers, embaixador na Espanha. Mesmo com apoios mais ou menos contundentes de seu círculo próximo, as políticas tomadas pelos Estados Unidos, principalmente a de nãointervenção, beneficiaram o General Franco. ${ }^{223}$

As preocupações de Roosevelt se tornavam cada vez mais públicas conforme aumentava a ajuda militar da Itália e da Alemanha aos rebeldes. Em 1937 foi promulgado um Ato de Neutralidade, direcionado à Guerra Civil Espanhola e que proibia o fornecimento de materiais aos dois grupos em conflito, abrindo a possibilidade de um posicionamento que contemplasse também guerras civis. Esse dispositivo foi criado em $1^{\circ}$ de maio de 1937, que seguia o mesmo rumo dos Atos anteriores, mas que apresentava cláusulas que incluíam algumas especificidades, como a enumeração de itens que poderiam ser comprados dos Estados Unidos por beligerantes e a proibição irrestrita de viagens de norte-americanos em navios beligerantes. No entanto, havia um elemento que dava a Roosevelt maior margem de manobra em relação à Guerra Civil na Espanha e frente ao surgimento de conflitos. ${ }^{224}$

No entanto, a partir de fevereiro e março de 1938, começou a haver uma alteração na postura norte-americana em relação ao conflito. Uma série de planos e ações estavam em curso para apoiar a República na tentativa de evitar a vitória de Franco, e consequentemente, o crescimento político e militar da Alemanha e da Itália. ${ }^{225}$ Pois, com a clara associação existente entre Franco, Hitler e Mussolini, além da presença do poder conservador de Salazar, a influência dos países aumentaria com o acréscimo da Espanha. Ademais, voltando-se a um pensamento militar, o cenário estratégico da França e da Inglaterra iria se encontrar em uma situação bastante delicada, pois, a Alemanha já possuía forte presença na fronteira pelo Oeste, pelo Sul e pelo Sudoeste. As fronteiras já eram fruto de preocupação devido à presença italiana e à própria anexação da Áustria, em 12 de março. Dessa forma, o controle das passagens, por meio dos Pirineus, em mãos de um governo francamente a favor da Alemanha, traria um enorme desequilíbrio no continente e tornaria a França um alvo que poderia ser alcançado com certa facilidade.

Esse interesse cresceu progressivamente até o fim do conflito, ao final de março de 1939. Ele não estava restrito somente à evolução do conflito, no qual as dificuldades do governo republicano haviam crescido ainda mais após a derrota na batalha de Teruel, em princípios de 1938. E também ao crescimento da ajuda de Hitler e Mussolini a Franco, além dos passos de

\footnotetext{
223 THOMÁS, Joan Maria. Roosevelt and Franco during the Second World War: from the Spanish Civil War to Pearl Harbor. New York: Palgrave Macmillan, 2008, p.5.

${ }^{224}$ FERREL, Robert H. op. cit., In: LEUCHTENBURG, William (org.). op. cit., p. 523.

225 THOMÁS, Joan Maria. op. cit., p.5.
} 
Hitler, dentro da política europeia durante a primavera de 1938, com a intenção de modificar o mapa europeu. A escalada de alterações à qual Hitler e Mussolini estavam instituindo já estavam em curso desde o ano de 1935, com o pedido de revisão do Tratado de Versalhes feito pela Alemanha, a invasão italiana na Abissínia e a própria intervenção de ambos na Espanha. Além disso, a Áustria havia sido anexada em março e as demandas alemãs de maio de 1938 em ocupar a região dos Sudetos tchecos, que foram concluídos com a invasão do exército hitlerista em outubro daquele ano. ${ }^{226}$

De forma mais generalizada, os Estados Unidos modificaram sua política para a Guerra Civil Espanhola a partir da Conferência de Munique, em 1938, principalmente devido à declaração de Hitler que proclamava uma política de anexações que levaria a Europa a um novo conflito. Após a Batalha do Ebro, Roosevelt apoiou a ideia Franco-Britânica de um armistício e confiou ao Secretário-assistente de Estado, Adolph Berle, um apoio junto ao Vaticano. E, também considerou a possibilidade de que Cordell Hull apresentasse na Conferência de Lima, em dezembro de 1938, a proposta de uma moção por um armistício na Espanha. Tal oferta, no entanto, não encontrou respaldo e não foi aprovada entre os países latino-americanos. ${ }^{227}$

Tardiamente, ainda em 1938, houve uma tentativa de se terminar com o embargo de proibição de vendas de armas para a Espanha. Havia dois caminhos para isso. Um deles, seria por meio do envio da proposta para o Congresso em janeiro de 1939. E, o outro, seria a partir da utilização do próprio Roosevelt de suas prerrogativas presidenciais. Pois, da mesma forma que havia impetrado o Ato de Neutralidade de 1937, que impedia o comércio de armas com países em guerra civil, fruto e direcionado à Espanha desde a resolução conjunta do Congresso em janeiro de 1937, Roosevelt acreditava que o fim daquele direcionado à Espanha poderia ser resolvido por um ato independente.

Com as preocupações no âmbito planetário do crescimento das forças fascistas, a situação regional não era distinta. Com sede em Lima, Peru, a $8^{\text {a }}$ Conferência Internacional de Estados Americanos ampliou o sistema de consultas entre os países do continente acerca de ameaças que poderiam desestabilizar a região. Claro que as ameaças se vinculavam diretamente aos interesses dos Estados Unidos.

No entanto, em 1938, já estava claro para os Estados Unidos e para os outros países americanos que a Guerra Civil Espanhola havia ultrapassado as fronteiras da Europa. Os seus efeitos, eram encarados pelos Estados Unidos de duas formas: por um lado, uma vigilância

226 THOMÁS, Joan Maria op. cit., p.6

${ }^{227}$ Ibidem, p. 7. 
diplomática sobre os posicionamentos específicos de cada país e a tentativa de influenciá-los para que mantivessem um perfil de neutralidade, como foi o caso brasileiro logo nas primeiras semanas de conflito; e, por outro, análises de como espanhóis que apoiavam o governo republicano e a presença de forças conservadoras se comportavam entre si e perante os governos nos territórios que estavam localizados.

A Conferência de Lima trouxe uma alteração a esse perfil, com a elaboração de documentos que apresentariam contundentes críticas à sublevação, ao próprio General Francisco Franco e ao próprio custo do conflito. A estratégia utilizada pelos Estados Unidos envolvia o envio de um telegrama ao governo franquista e republicano como uma das resoluções da $\operatorname{Lima}^{228}$ e uma proposta de mediação de armistício. ${ }^{229}$

O telegrama apresentava de forma peremptória uma proposta de trégua entre as partes em conflito:

A Conferência Internacional dos Estados Americanos, durante sessão em Lima, agindo no direito que as nações constituem para o reconhecimento para interesses de humanidade e civilização, propõe a conclusão de um armistício entre as forças rivais na Espanha que durará pelo período de um ano, a ser declarado por ambos os lados, com o entendimento que durante esse ano deverá ser feita uma tentativa para reconstituir uma nação espanhola unificada. ${ }^{230}$

O documento continha também a proposta de constituição de uma zona desmilitarizada para que, por meio de uma comissão apontada por ambos os lados, pudesse ser mediada as negociações e restabelecer um Estado espanhol unificado.

Deve ser acordado que apropriada cidade espanhola seja estabelecida como um distrito federal no qual nenhuma tropa deve ser estacionada, administrada por um comitê conjunto no qual ambos os lados estariam igualmente representados, que deve servir como assento da comissão anteriormente sugerida. ${ }^{231}$

No caso da resolução que seria apresentada, o governo norte-americano se utilizou de um de seus Estados-títeres no Caribe para a elaboração de uma resolução conjunta. O rascunho existente expõe o então governo cubano como o organizador de um tratado que envolveria até

\footnotetext{
${ }^{228}$ Cuban draft on Spain. Berle Papers, December 1938. FDR/PL

${ }^{229}$ Proposed telegram from the Lima Conference to the Spanish Government and to General Franco. Berle Papers, November $19^{\text {th }} 1938$. FDR/PL

${ }^{230}$ Ibidem, p. 2.

${ }^{231}$ Ibidem, p. 3.
} 
mesmo nações que apoiavam os republicanos, como o México. Em seu preâmbulo, o documento confidencial afirmava que:

Várias repúblicas deste continente, e especialmente o Uruguai, México e Cuba, desde as suas condições de poder e agindo nos estreitos limites impostos pela peculiar natureza do conflito espanhol, realizou certos pontos de seus conhecidos esforços para o estabelecimento da paz e de um possível e construtivo acordo da angustiante controvérsia. ${ }^{232}$

No entanto, pela falta de resultados em sua estratégia, parece que faltou aos Estados Unidos "combinar com os outros". Pois, tanto o telegrama como a resolução foram rechaçados no decorrer da Conferência. Além do próprio México, aliado ao governo republicano, por outro lado, haviao governo argentino com seus estreitos laços com o maior aliado de Franco, a Alemanha. Por motivos díspares, ambos não aprovaram a continuidade dessa proposta que já havia chegado em Lima plenamente redigido. ${ }^{233}$

Entre a Conferência de Lima e o fim da Guerra Civil, em março do ano seguinte, restou aos Estados Unidos aumentar a vigilância e o controle continental sobre os grupos de espanhóis vinculados ao fascismo. As representações locais falangistas, fosse em território norteamericano ou em outros países americanos, já haviam se tornado um dos braços do eixo nas Américas. Com o transcorrer da Segunda Guerra Mundial, também a partir de 1939, o governo Roosevelt voltou-se para o isolamento da Espanha do cenário internacional e tratou os espanhóis como colaboradores nazistas.

\footnotetext{
${ }^{232}$ Cuban draft on Spain. Berle Papers, December 1938, p. 01. FDR/PL

${ }^{233}$ Cf. TIERNEY, Dominic. FDR and the Spanish Civil War. Neutrality and Commitment in the Struggle that divided America. Durham and London: Duke University Press, 2007, p. 115-123.
} 


\section{O adeus à República Espanhola: alinhamento e reconhecimento do Estado franquista (1938-1939)}

\subsection{O Estado Novo no Brasil: esmorecimento republicano e fortalecimento sublevado}

O golpe que levou à criação do Estado Novo em 10 de novembro de 1937, promoveu a centralização do poder em Getúlio Vargas e a organização estatal brasileira imbuiu-se de uma lógica sustentada no fascismo europeu. Ainda que se possa discutir um completo mimetismo do fascismo europeu como forma do estadonovismo brasileiro, são indubitáveis as influências da Carta del Lavoro italiana e uma parcela da ritualística nazifascista europeia. No momento de sua criação o Estado varguista deixou de ter uma influência estrutural e constitucional de Weimar e se dirigiu à Roma de Mussolini.

No âmbito externo, houve uma inquestionável associação do novo regime com os Estados conservadores europeus. E, em um momento em que os embates políticos cresciam no continente europeu, a partir das demandas alemãs de ampliação de suas áreas de influência cresciam, a tendência inicial do governo Roosevelt foi de preocupação pela criação do Estado Novo, pois talvez estivesse em formação o "pior dos mundos" para as pretensões dos Estados Unidos na América Latina e, especialmente, em relação ao Brasil.

Com o alinhamento que a Argentina estabeleceu junto à Alemanha, o contraponto internacional era o Brasil. No entanto, com o surgimento do Estado Novo, em fins de 1937, além do caráter "italiano" que se revestia politicamente o Estado, a trajetória econômica BrasilEstados Unidos já se encontrava ameaçada.

Com o avanço da política comercial e de propaganda alemã, o Estado nazista havia se tornado o segundo parceiro comercial brasileiro, superando a Grã-Bretanha e com forte ameaça ao posicionamento, até então hegemônico, dos Estados Unidos. ${ }^{234}$ Mesmo com as tentativas anteriores do governo Roosevelt em impedir o avanço econômico alemão sobre a América Latina, ${ }^{235}$ houve um incremento nos intercâmbios entre Brasil e Alemanha. No âmbito comercial, a criação do sistema de caixa de compensação era vantajosa para o governo

\footnotetext{
${ }^{234}$ CORSI, Francisco Luiz. Estado Novo: Política Externa e Projeto Nacional. São Paulo: UNESP, 2000, p. 59.

${ }^{235}$ Em 1934, havia sido aprovado o Reciprocal Trade Agreement Act, que promoveria uma redução em até 50\% nos acordos bilaterais. A condição para tal redução se sustentava inicialmente na criação de reciprocidade das exportações de origem estadunidense. Cf. CORSI, Francisco Luiz. Op. Cit., p. 53.
} 
brasileiro, pois evitava a saída de divisas; e, no ano seguinte, em 1938, houve a assinatura de um contrato de fornecimento de armamentos pela empresa Krupp. ${ }^{236}$

Como vimos anteriormente, o ano de 1937, já havia sido de intensos contatos entre o Estado brasileiro e os representantes sublevados espanhóis no Brasil, com a ocorrência constante dos fluxos de envio de café e doações.

No mesmo diapasão da polarização interna brasileira do segundo semestre de 1937, também cresceram as preocupações do Encarregado de Negócios republicano a respeito da própria condição da Segunda República perante o governo brasileiro. Na última quinzena de outubro do mesmo ano, Fernando Morales Llamas registrou a condição pela qual passava o cenário político interno brasileiro. O eixo principal de sua análise era o tratamento generalizante que se prestava àqueles que, de alguma forma, faziam oposição ao Estado Vargas. Em suma, o rótulo de comunista cabia a todos que discutiam a primazia de Getúlio:

Por outro lado, a confusão intencionalmente difundida, que qualifica sob o denominador comum de 'comunismo' a todos os matizes do anti-facismo e da democracia ou simplesmente da oposição ao Governo, permite dirigir contra todos, sem distinção, a ofensiva governamental que além de fomentar o quanto pode uma sensação de pânico que paralise qualquer reação ao seu amparo e para dar forma de legalidade a uma instauração do fascismo no poder, se prepara uma reforma constitucional cuja aprovação facilmente se imporá e pela maioria das Câmaras - o Estado de Guerra não há deixado a salvo as imunidades parlamentares - que, permitindo ao partido Integralista (fascista) se acomodar no regime, também permita a este dar o poder aos seus inimigos de véspera conservando à cabeça da Nação ao atual Presidente, ou se as circunstâncias lhe impedirem, pondo no lugar uma pessoa de sua confiança e agrado. ${ }^{237}$

Ainda no mesmo informe enviado ao governo republicano, a partir das consequências da declaração de Estado de Guerra, Llamas continuou com a sua abordagem sobre a situação interna da política brasileira. Os boatos de um novo levante comunista, como havia ocorrido em 1935, teria sido a causa das atitudes de intervenção política da administração de Getúlio Vargas:

Congresso dos Deputados aprovou ontem petição Presidente da República para declarar estado de guerra todo país. Hoje será aprovado por Senado sem dificuldade. Petição obedece a requerimento conjunto do Ministro da Guerra e Ministro da Marinha anunciando existência grave conspiração comunista. Há preocupação país, surpreendido com tão grave medida em pleno período

\footnotetext{
${ }^{236}$ CORSI, Francisco Luiz. EstadoNovo: Política Externa e Projeto Nacional. São Paulo: UNESP, 2000, p. 59.

237 "Informe político" Do Encarregado de Negócios Fernando Morales Llamas ao Ministro de Estado. 23/10/1937. Rio de Janeiro. AMAE.
} 
eleitoral presente. Opinião geral assinala causa fundamental a pressão de elementos fascistas brasileiros em íntimo contato com afins internacionais aspiram prorrogação mandato Getúlio Vargas. Estado guerra dificultará muito meu trabalho defesa legalidade espanhola iniciada com grande fruto. ${ }^{238}$

Enquanto a missão diplomática republicana se preocupava com um cenário desfavorável que poderia piorar ainda mais a sua situação em terras brasileiras, a Junta Nacionalista Española en el Brasil mantinha a mesma estratégia dos anos anteriores: ações, por meio de contatos políticos, para obter, ao menos, o reconhecimento do status de beligerância. Se por um lado, as atitudes não haviam sido frutíferas, por outro, conseguiram perceber por meio das consultas feitas a outros governos e principalmente junto aos Estados Unidos, que a decisão de Vargas não seria isolada. A estratégia dual de negociação ${ }^{239}$ com o governo Roosevelt e a Alemanha nazista se confrontava com a estratégia de Burgos. De acordo com Cárcer y Lassance,

É significativo o rumo da política exterior que o Brasil, se apartando ou desinteressando-se cada dia mais dos assuntos europeus, para entrar em cheio na órbita dos Estados Unidos. Parece atacado pelo vírus da democracia em sua forma mais aguda.

(...) O próprio Ministro de Relações Exteriores, Sr. Pimentel Brandão, normalmente tão prudente, pronunciou um discurso muito inoportuno em um banquete, atacando aos países totalitários europeus. ${ }^{240}$

Se no período anterior ao Estado Novo, o papel da Guerra Civil Espanhola e dos grupos em combate possuíam protagonismo, ainda que de modo subsumido, na política externa brasileira, a partir de 10 de novembro com o golpe de Vargas, a Guerra Civil Espanhola tomou uma dimensão mais contundente. O "novo" papel do conflito espanhol envolveu diretamente a situação política brasileira, com uma associação direta entre a Segunda República Espanhola e o comunismo internacional. Enquanto o governo republicano e sua missão diplomática tinham

\footnotetext{
238 “Telegrama cifrado, no 21". Do Encarregado de Negócios Fernando Morales Llamas ao Ministro de Estado. 03-10-1937. Rio de Janeiro. AMAE

${ }^{239}$ A historiografia sobre os embates econômicos entre a Alemanha e o Brasil possui um conceito até certo ponto hegemônico sobre o tema, o da equidistância pragmática. De acordo com Gerson Moura: “(...) a política externa dos anos 30 pode ser descrita como uma política de equidistância pragmática entre as duas potências, tanto em questões comerciais, como políticas e militares". MOURA, Gerson. Neutralidade Dependente: o caso do Brasil, 1939-1942. In: Estudos Históricos, Rio de Janeiro, vol. 6, n. 12, 1993, p. 179. O mesmo autor desdobra ainda mais o conceito apresentado em sua obra, que apresenta um panorama sobre o posicionamento brasileiro na década de 1930 e durante a Segunda Guerra Mundial. Cf. Moura, Gerson. Sucessos e Ilusões: Relações Internacionais do Brasil durante e após a Segunda Guerra Mundial. Rio de Janeiro: FGV, 1991.

${ }^{240}$ Informa acerca politica interior e exterior del Brasil. Do Representante do Estado Nacional Espanhol no Rio de Janeiro (José de Carcer) ao Secretario de Relaciones Exteriores do Governo do Estado Espanhol em Salamanca. no. 104. 17/08/1937. AMAE
} 
motivos pelo caminho ideológico ora apresentado, o Gobierno de Burgos e seus representantes em solo brasileiro viam o novo regime como uma possibilidade a mais para serem reconhecidos como o governo de jure e de facto para o Estado espanhol.

A partir de então, a vigilância e o controle sobre cidadãos espanhóis e a própria missão diplomática republicana foram umas das constantes tônicas frente aos efeitos do conflito espanhol no Brasil. Mas, de forma concomitante, a tolerância aos atos da Junta e da Comisión se mantiveram. Ainda que em diversos momentos os próprios representantes dos sublevados desconfiassem das intenções de Vargas.

Na Península Ibérica, ainda em novembro de 1937, a repercussão sobre a alteração da condução política brasileira repercutiu em território espanhol. Em correspondência com o ministro Pimentel Brandão, o embaixador Alcebíades Peçanha apresentou as preocupações que o governo republicano tinha frente ao Estado Novo:

(...) que teve nesta capital a suspensão da Constituição e os actos governamentaes que della decorrem, foi a de animadversão dos meios extremistas, denotando, ainda uma vez, quanto estes interessam pela expansão communista no Brasil. ${ }^{241}$

As afirmações de Peçanha estavam muito mais próximas de um conservadorismo que atacava a própria Segunda República, ao fazer essa ilação de que o governo republicano seria uma ponte para o início de uma revolução comunista.

Embora a retórica do então embaixador brasileiro na Espanha estivesse próxima da retórica anticomunista em 1937, o surgimento do Estado Novo e todo o ambiente político conservador que o revestia, se apresentou de forma demolidora para as pretensões republicanas de que ainda conseguisse se manter como a administração legal. De acordo com Morales Llamas, ao tentar interceder pela própria legalidade do governo republicano, dez dias após o golpe de Vargas, seu desânimo é claro:

Sem grande fé no resultado da gestão, mas considerando que sempre se contribuirá para evitar que o mal se acentue, continuo enviando ao Ministério de Relações Exteriores protestos por quantos casos cheguem ao meu conhecimento que revelam a má disposição de espírito que nas esferas oficiais do país contra a causa da legalidade espanhola (...).

\footnotetext{
241 "Acontecimentos politicos do Brasil" - Oficio de Alcebíades Peçanha a Pimentel Brandão, no 60, 28/11/1937. AHI. Inclusive, no mesmo ofício, tem destaque por parte do embaixador de investimentos realizados por países do eixo: "A attitude da imprensa tem consistido na publicação de telegrammas breves de varias procedencias, sobre o Brasil, inclusive um de Londres sobre as vultuosas compras de titulos brasileiros, effecutadas por ordem de bancos italianos."
} 
Quanto seja reiterar a necessidade de diferenciar, como de fato são coisas perfeitamente diferentes, as atividades subversivas de elementos extremistas - si é que existem e as de caráter patriótico para com seu país de nossos compatriotas defensores das instituições Republicanas, entendo que é um trabalho útil que em parte pode impedir a manobra que para favorecer uma atuação mais ou menos ditatorial dos Poderes Públicos, antes promove que combate essa confusão. V. Exc em seu critério superior, me indicará se a minha atuação se encontra ou não atinada. ${ }^{242}$

Em princípios de 1938, a clara associação entre o governo republicano e o comunismo tomou contornos definitivos na análise do governo brasileiro e do Ministério de Relações Exteriores nacional. Uma das principais consequências do enfraquecimento contínuo que as representações diplomáticas da Segunda República sofreram foi as violações das malas diplomáticas direcionadas à Embaixada do Rio de Janeiro. Em 19 de janeiro de 1938, uma correspondência direcionada ao ministro brasileiro Mario de Pimentel Brandão apresentou fortes protestos sobre o rompimento dos lacres das correspondências:

Me permito remete a Vossa Excelência que um envelope dirigido ao Sr. Secretário desta embaixada, D. Fernando Morales Llamas, que foi aberto pela censura postal, rogando a Vossa Excelência que tome as medidas necessárias para que tal ato não possa se repetir.

(...)

Aproveito esta ocasião, Excelentíssimo Senhor Ministro, para lhe solicitar que examine de novo o conteúdo das Notas desta embaixada sobre as contínuas e reiteradas apreensões de folhetos, livros e impressos a ela dirigida. ${ }^{243}$

Além da própria desconfiança tomada em torno da representação diplomática da Segunda República, órgãos do governo brasileiro, como era o caso dos correios, que em agosto de 1938 já aceitavam as correspondências dos órgãos do governo de Franco, com franquia de documentos diplomáticos. A partir de correspondência da representação sublevada no Brasil que havia sido interceptada pelo governo republicano:

Em seu poder se encontram diferentes envelopes com os endereços indicados, e que ademais, aparece um carimbo em tinta com a inscrição de Representación del Gobierno Nacional de España - Brasil, em caráter de carimbo oficial.

Tais franquias certificadas foram aceitas pelas agências brasileiras de correios.

\footnotetext{
242 "Da conocimiento de quatro Notas a Relaciones Exteriores, protestando contra otras tantas consecuencias del ambiente poco favorable existente en el Brasil para la legalidad española". Do Encarregado de Negócios, Fernando Morales Llamas, ao Ministro de Relações Exteriores da Espanha. 20/11/1937. AMAE

${ }^{243}$ Comunicação da Embaixada da Espanha (Rio de Janeiro) ao Ministro Mario de Pimentel Brandão (Rio de Janeiro. 19/01/1938, p. 01. AHI
} 
Esta embaixada agradeceria muito ao Ministério de Relações Exteriores (...) que examinasse estes assuntos com um critério favorável que impedisse que fatos semelhantes pudessem se repetir. ${ }^{244}$

O aparente posicionamento privilegiado que a representação do Governo de Burgos no Brasil teria adquirido nos primeiros meses do Estado Novo, devido à associação do novo regime político brasileiro com os de viés conservador na Europa, sofreu um forte revés com a derrota da sublevação da Ação Integralista Brasileira em 1938. Ademais, a guinada que o governo varguista começou a fazer rumo aos Estados Unidos, principalmente com a ascensão do então embaixador em Washington, Oswaldo Aranha, ao cargo de ministro de relações exteriores, favoreceu ao Encarregado de Negócios dos sublevados perceber a adoção de um posicionamento publicamente pró-americano a partir de março de 1938. Segundo o próprio,

Para selar ainda mais a amizade yankee-brasileira, o Sr. Vargas nomeou Ministro de Relaciones Exteriores ao antigo Embaixador em Washington, Sr. Oswaldo Aranha, quem inaugurou sua atuação pronunciando um discurso do tipo 'democrático' no qual estende a mão a Roosevelt, seu governo e à nação norte-americana. ${ }^{245}$

Da mesma forma que a posse de Aranha causou desconforto para Cárcer, a alteração do posicionamento da imprensa, que até então apresentava um comportamento a favor dos países "totalitários", após a sublevação integralista as críticas começaram a se dirigir aos movimentos políticos e militares da Alemanha e Itália e daqueles que poderiam estar associados a eles, como era o caso dos militares rebelados. Ao observar que os aspectos, órgãos e posicionamentos de vieses favoráveis ao nazismo e fascismo transformaram-se em alvos de uma nova política de alinhamento pró-americana de Vargas, preocupa-se com a situação da representação do Governo de Burgos em território brasileiro:

Devemos reconhecer que por desgraça, a imprensa que tão a nosso favor estava em princípio, se manifesta mais fria para com a nossa Causa. Não aparecem artigos francamente contrários, mas dão marcada preferência às notícias de fonte vermelha ou simplesmente estrangeira que fazem ressaltar as tantas vezes mencionada e exagerada ajuda ítalo-alemã. Se vê claramente que nos incluem em sua declarada antipatia ao bloco fascista. ${ }^{246}$

\footnotetext{
244 "Memorandum". Da Embaixada da Espanha (Brasil) ao Ministério de Relações Exteriores do Brasil. 28/07/1938. AHI.

245 “Informe Político. no 46." De José de Carcer (Rio de Janeiro) ao Ministro de Asuntos Exteriores em Burgos. 31/03 /1938." AMAE.

${ }^{246}$ Do Encarregado de Negócios, José de Carcer (Rio de Janeiro) ao Ministro de Asuntos Exteriores em Burgos. 31/03 /1938." AMAE.
} 
E em conclusão à aproximação cada vez maior entre o governo brasileiro e o norteamericano, reforça a contradição que enxergava no Estado Novo brasileiro:

Em efeito, Excelentíssimo Senhor, as diretivas políticas do Brasil hoje em dia, não tem que buscá-las no Rio de Janeiro. Elas estão em Washington.

Existe, pois, aqui esta absurda contradição: Um país com uma Constituição totalitária (ou quase), de regime ditatorial, que diz combater ao comunismo e que pretende ser governado 'democraticamente' abrindo os braços ao judaísmo internacional y cobiçando a sombra protetora dos EUA. ${ }^{247}$

As preocupações de Cárcer não se restringiam à influência norte-americana ou aos efeitos que poderiam ter sobre a condição do Governo de Burgos na política interna brasileira. Mesmo porque, embora os rebelados tivessem declarado, como apontamos anteriormente, o Governo de Burgos em novembro de 1936, como o legítimo representante do Estado espanhol, a sua aceitação não era disseminada no âmbito internacional. Nas esferas da política latinoamericana, isso se refletia naqueles países que não haviam se alinhado com os Estados Unidos e que possuíam relações bastante aprofundadas com algum dos países do Eixo, como era o caso da Argentina.

A situação de tênue equilíbrio da questão argentina e a interferência do governo brasileiro tornou-se de ainda maior interesse e ressonância após o encontro de Oswaldo Aranha com José Maria Cantillo, o Ministro de Asuntos Exteriores da Argentina, após o retorno deste último de uma viagem à Roma.

Trataram, por fim, da questão de nosso reconhecimento. Segundo tenho entendido, esses senhores se limitaram a dizer que não seria feita nenhuma modificação substancial à política seguida até agora. Não pude obter ainda informes precisos sobre o que foi dito, mas o provável é que, tanto o Senhor Oswaldo Aranha, como o Embaixador yankee, tenham feito pressão sobre o Sr. Cantillo no sentido indicado. O creio tanto mais verossímil pelos informes que eu tinha davam a entender que o Ministro de Relações Exteriores da Argentina se mostrava muito favorável à nossa causa. ${ }^{248}$

As aproximações da representação dos sublevados no Brasil com a diplomacia alemã e italiana, apontava proximidades e distanciamentos durante o período da Guerra Civil. As aproximações davam-se como resultantes daquelas feitas no continente europeu no decorrer da

\footnotetext{
247 "Informe Político. Ofício no 46. " Do Encarregado de Negócios, José de Carcer (Rio de Janeiro) ao Ministro de Asuntos Exteriores em Burgos. 31/03/1938. AMAE

248 "Informe Político. Oficio n ${ }^{\circ}$ 60". Do Encarregado de Negócios, José de Carcer ao Ministro de Asuntos Exteriores em Burgos. Rio de Janeiro, 18/04/1938. AMAE
} 
Guerra Civil e que serviam como sustentáculo para as tentativas de reconhecimento do Governo de Burgos. No entanto, os contatos, ao menos no caso com a Alemanha, tiveram diversos momentos de recuo. Com o crescimento das críticas escritas pela imprensa e mesmo as do governo brasileiro aos países do Eixo, observava-se a ausência de atos ou declarações de defesa frente as críticas do governo brasileiro aos países ligados ou pertencentes ao Eixo. A iniciativa desse ato procede do embaixador alemão referindo-se que,

(...) emissão especial rádio noite do 16 corrente para América do Sul, (que ele qualificara como de 'contra-ataque') disse Representante da Alemanha que esta havia surtido efeito havendo notado apreciável mudança de atitude no Ministro de Relações Exteriores do Brasil que havia manifestado formalmente forte campanha anti-alemã. Me consta ontem Ministro de Justiça deu ordens terminantes ao Chefe da Censura nesse sentido. Embaixador alemão insistiu que seria de desejar que emissoras e imprensa países amigos tomassem atitude enérgica ante constantes e injustos ataques do Brasil à nações totalitárias, secundando desta forma ação do Reich. Disse, no entanto, que emissão a qual se eludia era demasiado violenta havendo telegrafado instruções para que no futuro não fosse atacada pessoa Presidente da República ${ }^{249}$

Ao remeter-se à sua atitude e do Embaixador italiano, reforçou sua posição de adotar um posicionamento defensivo frente à do embaixador alemão:

Tanto o Representante da Itália como eu nos abstemos de responder ou fazer qualquer comentário. Não pareceu oportuno que nós seguíssemos à Alemanha nesse terreno já que não fomos objeto humilhação nenhuma classe. Nos anunciou unicamente medidas de caráter geral. Creio interpretar desejos V.E. ao manter prudente expectativa. ${ }^{250}$

Ao analisar a Ação Integralista Brasileira em 1938, José de Cárcer, expôs as fraturas que percebeu no interior do grupo dos "camisas verdes" 251 e na frustrada tentativa de golpe, em 11 de maio do mesmo ano, ao atacar o Palácio Guanabara que redundou no banimento da AIB:

\footnotetext{
249 "Telegrama". Despacho n ${ }^{\circ}$ 78. Do Encarregado de Negócios, José de Carcer ao Ministro de Asuntos Exteriores em Burgos. Rio de Janeiro, 18/05/1938. AMAE

${ }^{250}$ Ibidem.

${ }^{251}$ Embora não pretendamos discutir o Integralismo, é necessário apontar que a produção historiográfica sobre o movimento integralista está envolta em diversas formas de construção historiográfica. As abordagens alcançam desde o ideário de Plínio Salgado e de outros líderes, como Gustavo Barroso, até aquelas que colocam o movimento como sendo uma reprodução puramente mimética do fascismo e/ou do nazismo. Nesse sentido, pode-se balizar essa discussão a partir dos estudos de CHASIN, José. O integralismo de Plínio Salgado: Forma de Regressividade no Capitalismo Hiper-tardio. São Paulo/Belo Horizonte: Ad Hominem/Una Editora, 1999. TRINDADE, Hélgio. INTEGRALISMO: o fascismo brasileiro na década de 30. Rio de Janeiro: DIFEL, 1979. VASCONCELLOS, Gilberto. A Ideologia curupira: Análise do Discurso Integralista. São Paulo: Brasiliense, 1979.
} 
Algumas noites atrás houve um conato de levante Integralista que foi sufocado sem dificuldade. Mas a sua preparação foi tão ingênua e tão infantis que os médios postos em prática que existem fundadas suspeitas de que foi tudo obra de agentes provocadores. ${ }^{252}$

O comentário quase caricato que Cárcer y Lassance enviou a Burgos sobre os integralistas foi fortalecido ao desenvolver a crítica a Plínio Salgado. Ao rememorar a negativa deste em participar do governo varguista na instituição do Estado Novo, em 1937, associou os fracassos do movimento como uma das deficiências de liderança do integralista. De forma subsumida, pode-se enxergar uma comparação com General Franco: enquanto este último avançava com os objetivos estabelecidos desde 1936 e havia desdobrado as formas administrativas iniciais em um estado que conseguiria expurgar o comunismo, ao integralista lhe faltavam condições mínimas de promover algum movimento semelhante no Brasil:

\begin{abstract}
Muita culpa tem o chefe do Integralismo, Plínio Salgado, quem por uma inconcebível falta de tática, não aceitou a mão que lhe estendia o Sr. Getúlio Vargas ao lhe oferecer a carteira de Instrução Pública. Como já tive a honra de adiantá-lo a V.E., o Sr P. Salgado demonstrou carecer por completo das características de um verdadeiro Chefe. ${ }^{253}$
\end{abstract}

A fracassada tentativa de derrubar Vargas, provocou um maior direcionamento das críticas do governo e da imprensa aos países europeus vinculados às posições nazifascistas e que consequentemente poderiam atingir os esforços da representação de Burgos no Brasil. A identificação do Integralismo como sendo uma representação ou mesmo um órgão vinculado à Alemanha e Itália que leva diretamente às ligações do grupo nacionalista com estes países. Conforme visão de Cárcer,

O resultado mais tangível do acontecido é o ataque sistemático da imprensa contra os europeus em geral e os países totalitários em especial, campanha que já se iniciou antes do movimento. ${ }^{254}$

E, da mesma forma em que teve lugar uma relação mais conflitiva com a Alemanha, com a emissão de programas que criticavam o governo de Hitler. Cárcer reforça a atitude, e de seu aliado italiano, em se distanciar de organizações ou ações que remetessem ao Integralismo

\footnotetext{
252 "Informe Político. N ${ }^{\circ}$. 46". De José Cárcer (Rio de Janeiro) ao Ministro de Asuntos Exteriores (Burgos). 31/03/1938. AMAE.

253 "Informe Político. Despacho no 78". Do Encarregado de Negócios, José de Carcer (Rio de Janeiro) ao Ministro de Asuntos Exteriores em Burgos. 18/05/1938. AMAE.

${ }^{254}$ Ibidem.
} 
ou às potências conservadoras da Europa. Ao comentar as repercussões do ataque integralista na imprensa, considera que,

Como V.E. poderá apreciar, o ataque é geral, mas se faz mais violento, mais pessoal, quando se trata da Alemanha. Tanto nós como a Itália, somente podemos nos queixar de certa frieza, sempre dentro da maior cortesia e isento de qualquer alusão ofensiva ou direta. De nossa parte, tivemos o maior cuidado e empenho em permanecer completamente alheios às lutas internas do Brasil, respeitando sempre suas leis e disposições. Esta linha de conduta, é preciso mais do que nunca mantê-la agora, nestes difíceis momentos. ${ }^{255}$

As preocupações de José de Cárcer pertenciam ao campo de uma certa razoabilidade. Pois, no ínterim entre o surgimento do Estado Novo e a tentativa da Ação Integralista, o governo brasileiro havia acelerado o processo de doações para o Gobierno de Burgos. E que se apresentava inicialmente sobre a inclinação do governo brasileiro aos militares espanhóis revoltosos.

\subsection{Os embarques de 1938: as interferências explícitas do Departamento Nacional do Café e do Lloyd Brasileiro}

A participação deliberada do governo brasileiro de enviar café à Guerra Civil Espanhola possui uma abordagem pela historiografia que enquadra ora o telegrama de agradecimento do General Franco em 1936, ora a doação pela Cruz Vermelha internacional em 1938. Recentemente, Angel Viñas publicou uma obra que aborda o enriquecimento de Vargas após $1940^{256}$ em um momento que já havia sido restaurada as conexões comerciais entre os dois países.

No entanto, existem embarques realizados em 1938, que foram feitos por meio do Departamento Nacional de Café e que chegaram ao governo franquista por intermédio de Portugal. E a diferenciação entre esses embarques é essencial para compreender que houve o envio para o General Francisco Franco, por meio da Junta Nacionalista sediada no Brasil e seu braço de propaganda, a Comisión Nacionalista Española. As negociações para o envio tiveram como lapso temporal entre final de 1937 e o ano de 1938 e envolveram, além das organizações sublevadas em território brasileiro, o DNC e a companhia de navegação Lloyd Brasileiro.

\footnotetext{
255 “Informe Político. Despacho no 78”. Do Encarregado de Negócios, José de Carcer (Rio de Janeiro) ao Ministro de Asuntos Exteriores em Burgos. 18/05/1938. AMAE

${ }^{256}$ Cf. VIÑAS, Ángel. La Otra Cara del Caudillo. Mitos y realidades en la biografía de Franco. Barcelona: Crítica, 2015.
} 
No biênio 1937/1938 o fluxo comercial de café variou entre remessas esparsas, como foi o caso das Ilhas Canárias, e o envio constante, ainda que em pouca quantidade, para o Marrocos Espanhol. Nesse caso, embora possamos inferir que havia um comércio regular desde o Brasil, não foi possível concluir se era direcionado ao exército rebelado estacionado no norte da África ou se era apenas para consumo da população local. Por outro lado, em relação ao território espanhol continental pode-se verificar que no ano de 1937 não se registra nenhum embarque, enquanto que em janeiro e fevereiro de 1938 houve um total de 10.166 sacas de café enviadas à Espanha.

Em um cenário amplo dos embarques de café para o território espanhol continental, as Ilhas Canárias e o Marrocos Espanhol temos a seguinte situação entre 1937 e 1938:

\begin{tabular}{|c|c|c|c|c|c|c|}
\hline \multicolumn{7}{|c|}{ 3.1 Variações mensais de exportação de Café, 1937-1938 (Em sacas de 60 kg) } \\
\hline & \multicolumn{2}{|c|}{ Espanha } & \multicolumn{2}{|c|}{ Ilhas Canárias } & \multicolumn{2}{|c|}{ Marrocos Espanhol } \\
\hline & 1937 & 1938 & 1937 & 1938 & 1937 & 1938 \\
\hline Janeiro & - & 5.166 & 950 & - & 500 & 1.477 \\
\hline Fevereiro & - & 5.000 & - & 700 & - & 1.715 \\
\hline Março & - & - & - & 589 & 63 & 1.520 \\
\hline Abril & - & - & - & - & 135 & 1.162 \\
\hline Maio & - & - & 250 & - & 188 & 1.139 \\
\hline Junho & - & - & 600 & - & 126 & 1.231 \\
\hline Sub-total $1^{o}$. Sem. & - & 10.166 & 1.800 & 1.289 & 1.012 & 8.244 \\
\hline Julho & - & - & - & 600 & 313 & 1.364 \\
\hline Agosto & - & - & - & - & 250 & 1.124 \\
\hline Setembro & - & - & - & - & 664 & 151 \\
\hline Outubro & - & - & - & - & 406 & 287 \\
\hline Novembro & - & - & - & - & 126 & 1.279 \\
\hline Dezembro & - & 1.000 & 600 & - & 589 & 1.025 \\
\hline Sub-Total $2^{o}$. Sem. & - & 1.000 & 600 & 600 & 2.348 & 5.230 \\
\hline Total: Ano & - & 11.166 & 2.400 & 1.889 & 3.360 & 13.474 \\
\hline
\end{tabular}

Fontes: BRASIL. DEPARTAMENTO NACIONAL DO CAFÉ. SECÇÃO DE ESTATÍSTICA. Anuário Estatístico do Café, 1939/40. Rio de Janeiro, 1941, pp. 378, 390 e 419.

Como vimos anteriormente, o envio de café das organizações sublevadas organizadas no Brasil ocorreu desde o princípio da Guerra Civil Espanhola. ${ }^{257}$ No entanto, nos envios que ocorreram no final do ano de 1938, surgiram os documentos originados de órgãos brasileiros.

${ }^{257}$ Cf. Capítulo 2, item 2.4. 
A trama para o envio do café durou todo o ano e foi articulada por José de Cárcer e o então presidente do DNC, Jaime Guedes. A estratégia estabelecida envolveu desde as quantidades que seriam embarcadas até a nomeação daqueles que seriam responsáveis pelo envio e pelo recebimento do café nos territórios espanhóis controlados pelos nacionalistas. $\mathrm{O}$ principal caminho que foi tomado pelo governo varguista para a sua colaboração junto aos rebelados espanhóis, passou necessariamente pela própria cabeça do governo brasileiro, Getúlio Vargas, por familiares seus e por órgãos e empresas estatais. Neste movimento de colaboração destacaram-se a participação direta do Departamento Nacional do Café (DNC) e do Lloyd Brasileiro.

Em 27 de junho de 1937, José Carcer recebeu um telegrama de Salamanca em que aceitava a doação de café engendrada no interior do governo varguista e que fossem tomados os meios necessários para o envio das sacas à zona controlada pelos militares rebelados:

Aceita-se satisfação donativo café abonando saldo refere-se aqui pesetas caso não conseguir isenção gestiona abono cargo créditos bloqueados Brasil. ${ }^{258}$

O processo de doação de café ao Governo Nacional, sediado em Salamanca, iniciou-se por meio do responsável pela propaganda do café brasileiro no Estado espanhol, José Fernandez Alcazar. Em fins de novembro, em um telegrama enviado ao secretário de relações exteriores dos rebelados, José de Cárcer expõe que por meio do "controlador de propaganda", houve o oferecimento de aproximadamente 50 mil sacas de café.

Segundo o próprio ao se encontrar com o presidente do Departamento Nacional do Café, Jaime Guedes, foi tratado que,

(...) caso nosso governo aceite donativo deveria comprometer-se pagar salário a Alcazar que elevasse cento e cinquenta libras mensais pagáveis ao interessado na Espanha durante um ano. Tramito isenção imposto oficial doze mil réis por saca assim como desconto frete esperando consegui-lo. Devendo entrar entendimento definitivo com departamento quinta-feira próxima mediante troca cartas rogo V.E. instruções antes essa data autorizado concluir acordo bases indicadas se o estima oportuno mesmo quando fosse mister pagar imposto referência. ${ }^{259}$

\footnotetext{
258 Telegrama n. 80656 da Secretaria de Relaciones Exteriores (Salamanca) ao Representante do Governo Nacional no Brasil, Jose de Carcer. 27/06/1937. AGA.

${ }^{259}$ Telegrama de José de Cárcer, representante do Governo Nacional no Brasil, Rio de Janeiro, ao secretário de relações exteriores do Governo Nacional da Espanha. 29/11/1937
} 
A generosa oferta compreendia tanto o desconto nos impostos, bem como um acordo para a manutenção do representante do DNC junto ao território controlado pelos militares rebelados:

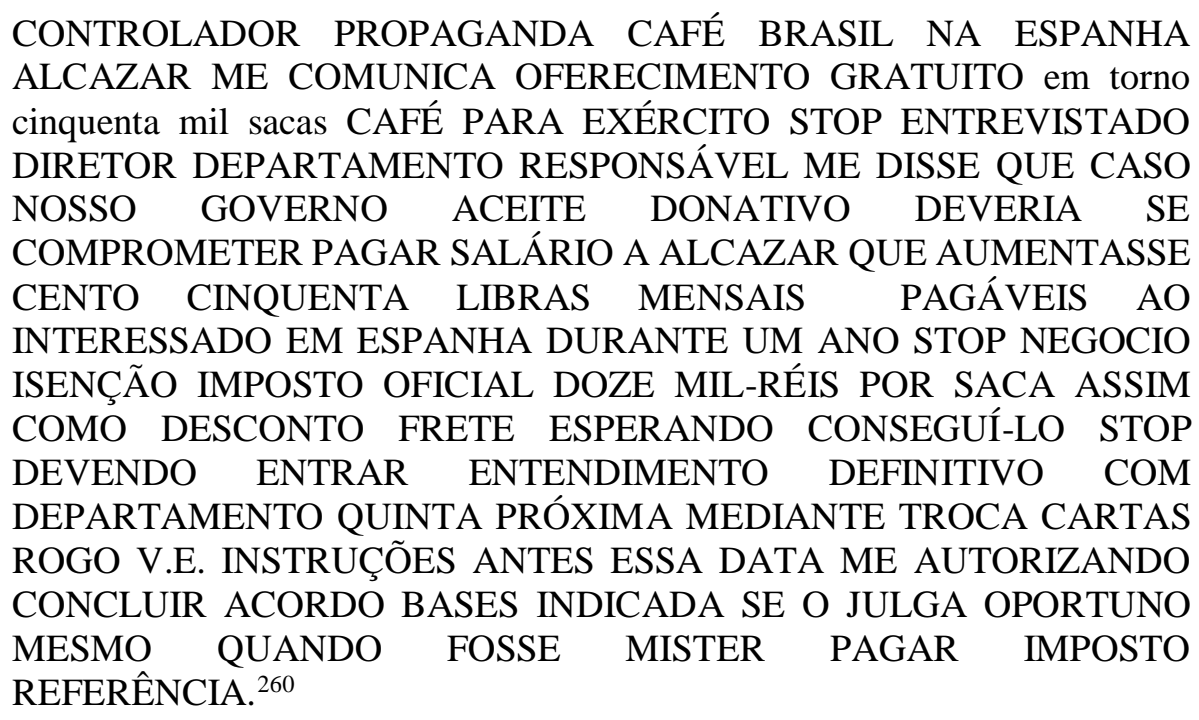

Entretanto, por motivos ainda não identificados, houve uma abrupta queda na quantidade de sacas de café que Cárcer y Lassance aceita. Das 50.000 sacas iniciais, diminuiuse para um total de 10.000. A diminuição no montante total pode estar vinculada aos custos que a Comisión e a Junta Nacionalista teriam que arcar com o envio e que havia ficado sob os seus auspícios.

Em 9 de dezembro, Cárcer responde a Jaime Guedes a respeito da aceitação do donativo feito e as condições propostas pelo governo brasileiro. Ainda que seja a resposta de um acordo verbal feito entre as duas partes, o representante do Governo Nacional não teima em ressaltar a participação de Vargas em tal donativo do Departamento Nacional do Café às forças militares nacionalistas,

Tenho a satisfação de confirmar, por meio desta, o entendimento verbal que com Vossa Excelencia tive, e de novo agradeço em nome do meu Governo e no meu próprio nome, o valioso donativo de dez mil saccos de café, livre de taxas que fez ao nosso Exercito, por intermédio de V.Excia., o Exmo. sr. Presidente Dr. Getulio Vargas, deixando reconhecida essa heroica tropa se bate pela Civilização contra as ideas devastadoras do Communismo. ${ }^{261}$

\footnotetext{
260 Telegrama 87. De Jose Fernández de Carcer, representante do Governo Nacional da Espanha no Brasil, ao Secretario Relaciones Exteriores (Salamanca). 29/11/1937. 51/16463. AGA

${ }^{261}$ Carta de Jose de Cárcer, Representante do Governo Nacionalista no Brasil, a Jaime Guedes, presidente do Departamento Nacional do Café, 09/12/1937. AGA
} 
$\mathrm{O}$ acerto final entre as duas partes, ou seja, o DNC e o representante do Governo Nacional de Espanha, expunha as condições finais da doação realizada. Assim, ficou-se definido que,

\begin{abstract}
A nossa Agência desta Capital está autorizada a entregar esse donativo ao Sr. Victor Fernandez Alonso, Presidente da 'Comission Nacionalista Española, e cujos embarques deverão ser feitos parceladamente, em quantidades não excedentes a três mil sacas. ${ }^{262}$
\end{abstract}

Ademais, também designava, em definitivo, o responsável por receber e acompanhar a doação no território controlado pelos nacionalistas. Em uma carta apontada como "Confidencial" e de origem da Presidência do DNC, José Fernandez Alcazar foi designado como o fiscal de recebimento das sacas doadas pelo governo brasileiro. Em seu conteúdo, afirma que:

(...) este Departamento, tendo feito um donativo de 10.000 (dez mil) sacas de café ao Governo Nacional de Espanha resolveu designa-lo para fiscal da sua aplicação naquelle pais, mediante uma remuneração (...) que lhe será paga pelo referido Governo. ${ }^{263}$

Além do donativo feito ao exército nacionalista, José de Cárcer iniciou um processo de obtenção de outras vantagens para o embarque do café para o território espanhol. Esse processo tomou corpo com a solicitação junto ao Diretor do Lloyd Brasileiro, o Almirante Graça Aranha, em que obteve um desconto de 30\% "nas despesas referentes ao transporte de cinco mil saccos de café com destino a Salamanca para o Exercito Nacionalista Espanhol". ${ }^{264}$

$\mathrm{O}$ próprio representante eleito do DNC junto às regiões franquistas, José Fernandez Alcazar, recebeu em correspondência confidencial do presidente do Departamento Nacional do Café, uma comunicação para sua designação como fiscal de que,

Levamos ao conhecimento de V.S. que este Departamento, tendo feito um donativo de 10.000 (dez mil) sacas de café ao Governo Nacional de Espanha, resolveu designa-lo para fiscal da sua aplicação naquele pais, mediante uma

\footnotetext{
${ }^{262}$ Carta de Jaime Guedes, presidente do Departamento Nacional do Café, a José Carcer, Representante do Govêrno Nacional de Espanha. Rio de Janeiro. 23/12/1937. AGA

${ }^{263}$ Ibidem.

${ }^{264}$ Correspondência entre José de Cárcer, representante do Governo Nacional da Espanha no Brasil, e o Almirante Graça Aranha, Diretor do Lloyd Brasileiro. Rio de Janeiro, 22/12/1937. AGA
} 
remuneração mensal de $£-150$ (cento e cincoenta) libras esterlinas), que the será paga pelo referido Governo. ${ }^{265}$

O pagamento do frete foi feito pela Comissión Nacionalista Española, que embora segundo o próprio representante afirmava que não havia o valor em caixa, mas que de vido ao parcelamento do embarque, essa situação havia sido contornada.

(...) como os envios serão escalonados, com o produto das arrecadações mensais poderão sem grande esforço se reintegrar as somas adiantadas para tal fim. ${ }^{266}$

A confirmação por parte de Jaime Guedes, Presidente do DNC, veio somente nos últimos dias de 1937, quando apresentou todos os termos do embarque concedido ao Governo Nacional. Além da negociação realizada relacionada ao embarque em si, durante os dois últimos meses de 1937, algumas pendências não haviam sido apresentadas no interior da documentação analisada. Dessa forma, se por um lado, a quantidade, a forma de embarque, o pagamento e os intermediários haviam sido determinados, havia também a forma como se daria o desembarque e o recebimento da mercadoria por meio do fiscal do DNC, José Fernandez de Alcazar.

O parcelamento do embarque, o receptor ainda no Brasil e seu par no território do Governo Nacional apresentaram-se na correspondência recebida por José de Carcer:

Confirmamos a concessão do donativo de 10.000 sacos de café ao Governo Nacional da Espanha. Nossa Agência desta capital está autorizada a entregar esse donativo ao Sr. Victor Fernandez Alonso, Presidente da COMISSÃO NACIONALISTA ESPAÑOLA, cujos embarques deverão ser efetuados em partidas que não excedam de três mil sacas. Designamos para fiscal da aplicação de dito café na Espanha ao Sr. José Fernandez de Alcazar, mediante uma remuneração mensal de $£-150$ (Cento cinquenta libras esterlinas), que the será pago pelo Governo Nacional daquele país. ${ }^{267}$

Ainda em 30 de dezembro de 1937, Cárcer enviou uma correspondência à Secretaria de Relações Exteriores do Governo Nacional. Nesse documento, assinalou que da doação das 10.000 sacas havia surgido diversos problemas para o embarque. As dificuldades

\footnotetext{
${ }^{265}$ Correspondência confidencial de Jaime Guedes, presidente do Departamento Nacional do Café, e José Fernandez Alcazar, Rio de Janeiro, 23/12/1937. AGA.

${ }^{266}$ Carta de José de Cárcer, representante do Governo Nacional de Espanha, ao Secretario de Relaciones Exteriores. Rio de Janeiro. 30/12/1937. AGA.

${ }^{267}$ Carta de Jaime Guedes, Presidente do Departamento Nacional do Café, a Jose de Carcer, representante do Governo Nacional da Espanha no Brasil. 27/12/1937 (AGA). Em anexo, na mesma pasta, existe uma tradução para o espanhol.
} 
concentravam-se em todos os quesitos necessários para o embarque de qualquer mercadoria, ou seja, os impostos de exportação, os gastos de transporte e de seguro.

No mês anterior ao primeiro embarque, José de Carcer por meio de uma carta confirmou junto ao diretor do Lloyd Brasileiro, o Almirante Graça Aranha, uma diminuição no preço dos custos. O conteúdo da missiva solicitava:

(...) o abatimento de trinta por cento nas despesas referentes ao transporte de cinco mil sacos de café com destino a Salamanca para o Exercito Nacionalista Espanhol ${ }^{268}$

Em resposta, na primeira semana de 1938, o presidente da Comisión Nacionalista Española, Victor Fernandez Alonso, a quem José de Cárcer havia delegado a responsabilidade pelo embarque da doação recebeu a seguinte correspondência do Lloyd:

Em referencia á sua carta de 22 de Dezembro ultimo sobre o transporte de café para a Hespanha Nacionalista, pedimos a fineza do seu comparecimento a esta Séde (Directoria) afim de tratar do assumpto. ${ }^{269}$

As dificuldades do pagamento do frete por parte da Comissión Nacionalista foram amenizadas por um desconto que foi fornecido pelo Lloyd Brasileiro. O primeiro embarque, concretizado em 24 de janeiro, que Cárcer cita em sua correspondência, foi de um total de 5.000 sacas transportadas pelo vapor "Cuyabá". Além da afirmação do próprio representante do Governo Nacional, verifica-se que o Lloyd apoiou esse embarque de forma incondicional, que envolveu tanto o abatimento no frete, bem como na alteração, de forma oculta, da rota do vapor da companhia:

(...) desejo agradecer a Vossa Excelência o apreciável abatimento concedido no frete dessa remessa.

Ao agradecimento junto o meu reconhecimento e satisfação sabendo que o próximo vapor da linha da Europa tem ordem para fazer escala em Vigo, o primeiro passo para o restabelecimento do serviço há tempos interrompido e o marco de uma nova era de intercâmbio hispano-brasileiro ${ }^{270}$

\footnotetext{
${ }^{268}$ Carta de Jose Fernández de Carcer, representante do Governo Nacional da Espanha no Brasil, ao Almirante Graça Aranha, Diretor do Lloyd Brasileiro. 22/12/1937. AGA

${ }^{269}$ Carta do Almirante Haroldo de Graça Aranha, Diretor do Lloyd Brasileiro, a Victor Fernandez Alonso, Presidente da "Comision Nacionalista Española". Rio de Janeiro. 03/01/1938. AGA

${ }^{270}$ Carta de José de Cárcer ao Almirante Graça Aranha. 22/01/1938. AGA
} 
A forma oculta pela qual foi realizada a doação junto ao Governo Nacionalista, começou a tomar contornos muito mais claros a partir deste momento. Pois, segundo o descrito por Cárcer, o navio deveria aportar em Vigo, região Noroeste do território espanhol e que já desde os primeiros meses do conflito intestino já estava sob o controle dos nacionalistas. E, afirma, que tal escala do "Raul Soares" deveria ser realizada de forma célere e discreta, pois a sua passagem por Vigo não constaria na rota original do navio:

(...) que está disposta a atracar no porto de Vigo caso este Governo o consinta, não obstante não figurar tal porto como escala de sua rota.

Caso o barco se detenha em Vigo, seria muito conveniente, por razões que V.E. compreenderá, fosse isento o barco de qualquer imposto ou taxa de porto, lhe concedendo toda a documentação grátis e também solicitaram com grande interesse que se procure por todos os meios efetuar o desembarque com a máxima rapidez para que isso não representasse um sensível atraso em seu itinerário normal, o que impediria deter-se em viagens futuras.

Pelo anteriormente exposto, rogo a V.E. dê as oportunas ordens para que as autoridades marítimas de Vigo concedam todas as facilidades ao desembarque de referência, procurando descarregar o barco no menor tempo possível ${ }^{271}$

Um segundo embarque de 5.000 sacas foi realizado em 25 de fevereiro de 1938 e transportado por meio do vapor "Almirante Alexandrino", com programação para chegar no dia 17 do mês seguinte:

(...) tenho a honra de informar a V. Exc. Que no vapor brasileiro "Almirante Alexandrino" que saiu deste porto no dia 25 passado, embarcaram com a destino a Vigo 5.000 sacas de café, segundo envio das 10.000 oferecidas por este governo ao nosso glorioso exército. ${ }^{272}$

Ressaltamos que a diferença que se apresenta nos embarques de 1938 e aqueles de finais de 1936, é a sustentação documental sobre eles. Enquanto, em 1936, somente por meio das comunicações dos líderes da Junta Nacionalista Española e da Comisión Española Nacionalista havia registros; no biênio posterior, reuniram-se tanto as documentações originárias dos órgãos sublevados no Brasil, os conhecimentos de embarque e pagamentos de taxas de embarque e as comunicações do presidente do Lloyd Brasileiro.

\footnotetext{
271 “Informa proximo embarque 5.000 sacas café destinadasa nuestro Ejercito". Carta de José de Cárcer, representante do Governo Nacional de Espanha, ao Secretario de Relaciones Exteriores. Rio de Janeiro. 30/12/1937. AGA.

272 "Comunica embarque de 5.000 sacas café destinadas porto de Vigo e remete conhecimento de carga". Carta de José de Cárcer a Secretaria de Asuntos Exteriores. 06/03/1938. AGA
} 
A doação secreta executada por meio do DNC é distinta às outras duas que foram discutidas pela historiografia sobre os embarques de 1938 e ressaltada recentemente ${ }^{273}$ : a de um embarque dedicado aos republicanos e a um segundo embarque enviado ao governo franquista.

No caso do café doado ao governo republicano em fins de 1938, ele não iria diretamente ao território espanhol desde os portos brasileiros. O seu envio seria feito primeiramente a portos dos Estados Unidos e de lá partiriam para a Espanha. A triangulação feita foi reconhecida pelo próprio Cárcer y Lassance:

(...) embarque de 10.000 sacos de café que este Governo destina à população civil da Espanha, tenho a honra de informar a V.E. que segundo me comunica nosso Cônsul em Santos, o Departamento Nacional do Café de tal cidade recebeu a autorização para proceder tal embarque.

A mercadoria irá, parece, a bordo do "Algie", da AMERICAN REPUBLIC LINE, que sairá deste porto no dia 28 do corrente com destino aos portos de Jacksonville, Norfolk e Baltimore. ${ }^{274}$

O envio de forma triangulada por portos americanos e a Cruz Vermelha dos Estados Unidos, reflete nos números (ou na falta deles) de exportação para a Espanha continental em janeiro de 1939. De acordo com os dados disponíveis, entre janeiro e abril de 1939 não houve nenhum tipo de exportação para portos espanhóis. ${ }^{275}$ A confirmação por parte de Cárcer do referido embarque aconteceu em 6 dezembro e foi avalizado, segundo o próprio, pelo DNC e o MRE brasileiro:

(...) me foi informado neste Ministério de Relações Exteriores, foram embarcadas no porto de Santos 10.000 sacas de café com destino à Cruz Vermelho norte-americana, nos dias 29 e 30 de novembro passados.

Este governo concedeu este donativo a pedido da referida entidade e se destina às "populações necessitadas de Espanha".

Se deixou a critério de dita Cruz Vermelha, a distribuição dessa partida de café, não intervindo, por conseguinte, o governo brasileiro em sua partilha posterior.

\footnotetext{
${ }^{273}$ Em entrevista recente, dois pesquisadores das relações entre Brasil e Espanha, Carlos Sixirei Paredes e Ismara Izepi de Souza, citados no decorrer desta pesquisa, comentaram, em junho de 2016, acerca da documentação sobre os embarques que desenvolvemos nesse item da nossa pesquisa. "Como o café brasileiro enriqueceu o ditador espanhol Francisco Franco". Disponível em:

$<$ http://operamundi.uol.com.br/conteudo/noticias/44469/como+o+cafe+brasileiro+enriqueceu+o+ditador+espanh ol+francisco+franco.shtml $>$. Acesso em: 18 jul. 2016.

274 "Sobre envio 10 mil sacos de café". José de Cárcer (Rio de Janeiro) al Ministro de Asuntos Exteriores (Burgos). 16/11/1938. AGA.

275 BRASIL. DEPARTAMENTO NACIONAL DO CAFÉ. SECÇÃO DE ESTATÍSTICA. Anuário Estatístico do Café, 1939/40. Rio de Janeiro, 1941, p. 390.
} 
A mercadoria foi embarcada para Nova York no vapor "Argentina", da American Republic Lines. ${ }^{276}$

A análise que José de Carcer y Lassance enviou, sobre os embarques dedicados à Cruz Vermelha nos Estados Unidos, poderiam sugerir mais uma alteração do posicionamento de Vargas sobre o conflito espanhol e os interesses dos sublevados no Brasil. Mas, em setembro de 1938, ele receberia uma solicitação que não deixaria mais margens a dúvidas a respeito de qual lado o governo brasileiro estava em relação à Guerra Civil Espanhola: o pedido de fornecimento de material para a Exposição Anticomunista.

\subsection{A Exposição Anticomunista e o ataque o governo republicano}

Após a adesão ao Pacto Anti-Komintern, em 6 de novembro de 1937, a Itália começou a planejar gestões para que o Brasil também aderisse a ele. Ademais, Ciano também adiciona a Espanha com o Brasil como uma forma de prolongamento do Eixo no Atlântico e a Polônia, como uma trincheira antirrussa. Ainda que o então embaixador em Roma, Guerra Duval, não se animasse muito com a ideia, ela foi transmitida ao Itamaraty. Em relação à Alemanha, a partir de 11 de novembro de 1937, ela também iniciou a busca pela ampliação do Pacto na América Latina. Além do Brasil, também desejava a inclusão do Chile e da Argentina. ${ }^{277}$ Entretanto, como parte da estratégia de suas relações com os Estados Unidos, o governo brasileiro recusou a sua adesão ao Pacto.

Após assumir o Ministério de Relações Exteriores em março de 1938, Oswaldo Aranha reforçou a tendência pró-americana no cerne do governo federal. Com a ampla presença de imigrantes estrangeiros, principalmente de membros do Eixo, como também espanhóis, o governo brasileiro agiu para evitar manifestações de presença externa. Essas ações sustentaramse por meio do Decreto-Lei n ${ }^{\circ} 383$, de 18 de abril de 1938. Especificamente no segundo artigo de tal Decreto havia a proibição de ações estrangeiras de cunho político. Em princípios de 1938, o Decreto atingia de forma bastante contundente a tentativa de retomada de organização do Partido Comunista, desmantelado e proibido devido ao levante de 1935. Duas alíneas, particularmente chamam a atenção:

\footnotetext{
276 "Sobre donativo 10 mil sacas de café. Cruz Roja Norteamericana". José de Cárcer (Rio de Janeiro) al Ministro de Asuntos Exteriores (Burgos). 06/12/1938. AGA.

${ }^{277}$ RODRIGUES, José Honório; SEITENFUS, Ricardo A. S. Uma História Diplomática do Brasil (1531-1945). Rio de Janeiro: Civilização Brasileira, 1995, p. 376-377.
} 
Al. 1 - Organizar, criar ou manter sociedade, fundações, companhias, clubes e quaisquer estabelecimentos de caráter político, ainda que tenham por fim exclusivo a propaganda ou difusão, entre os seus compatriotas, das idéias, programas ou normas de ação de partidos políticos do país de origem.

(...)

Al. 3. - Hastear, ostentar ou usar bandeiras, flâmulas e estandartes, uniformes, insígnias ou quaisquer símbolos de partido político estrangeiro. ${ }^{278}$

No interior das determinações históricas do período, este Decreto deveria ter ampla abrangência, no entanto, percebe-se claramente que ele foi direcionado ao Partido Comunista e à Ação Nacional Libertadora, principalmente no que tange à demonstração de símbolos de partidos políticos estrangeiros. Além de atingir claramente os interesses alemães, cuja colônia estava bastante enraizada, com formação e escolas em alemão que seriam proibidas, com predominância de professores brasileiros e sem ajuda externa. ${ }^{279}$ Havia também uma crise em relação à Itália, principalmente pelo apoio que deu aos integralistas. ${ }^{280}$

Nesse sentido, a Comissão Nacionalista, comandada por Jose de Carcer, também deveria ter sido atingida, no entanto, isso não aconteceu. Um dos pontos de inflexão que mostrou o apoio e a aproximação do governo brasileiro junto aos conservadores espanhóis ocorreu a partir da Mostra Anticomunista, em outubro de 1938. Nesse evento, que se vinculava à Exposição do Estado Novo, grande parcela do material de propaganda anticomunista foi fornecido pelo Governo Nacional sediado em Burgos.

Em setembro de 1938, houve a comunicação ao Ministério do Interior e ao Servicio Nacional de Propaganda a respeito de uma solicitação de envio de materiais para o Brasil de forma bastante acelerada. $\mathrm{O}$ percurso a ser utilizado seria a rota inversa daquela empregada para as doações de café e outros insumos:

Nosso representante, dada a premência do tempo, pois a Exposição será inaugurada em 10 de novembro próximo, solicita a urgência do envio e recomenda que o remeta pelo caminho do seu despacho anterior - o Comissário ou Capitão de um buque alemão da Companhia Hamburguesa que pare em Lisboa - o melhor material fotográfico que possa dispor, pois tanto a Itália como a Alemanha, se preparam para contribuir à referida Exposição Anticomunista, com grande aporte de elementos de informação. ${ }^{281}$

\footnotetext{
${ }^{278}$ Diário Oficial de 19 de abril de 1938, p. 7357-7359.

279 Cf. RODRIGUES, José Honório; SEITENFUS, Ricardo A. S. Uma História Diplomática do Brasil (15311945). Rio de Janeiro: Civilização Brasileira, 1995, p. 385-386.

${ }^{280}$ Ibidem. p. 387-388.

281 “Exposición anticomunista en el Brasil. Da Secretaria de Relaciones Exteriores al Señor Ministro del Interior y Servicio Nacional de Propaganda (Burgos). 20/09/1938. AMAE.
} 
A Exposição Nacional do Estado Novo ou (Exposição Anticomunista e de Obras e Realizações do Presidente Getúlio Vargas) criada como propaganda para o enaltecimento do governo varguista ocorreu entre 10 e 25 de dezembro de 1938. De forma geral, a organização dos diversos pavilhões intencionava demonstrar os avanços que a estrutura governamental de Vargas teria obtido, a partir de exemplos oriundos dos diversos ministérios. No entanto, a exposição não se concentrou somente em mostrar as possíveis vantagens do processo industrial, das reformas educacionais implementadas ou mesmo da dinâmica agrícola. Como foi descrito em A Noite, também houve a criação de um “curiosíssimo 'stand' de propaganda anticomunista". ${ }^{282} \mathrm{O}$ destaque dado à exposição anticomunista não era algo casual de alguns periódicos, mas foi apresentado e divulgado de forma ampla pela imprensa no período. $\mathrm{O}$ rescaldo de novembro de 1935 ainda estava presente. Como expôs o Jornal do Brasil:

Constitue ponto de grande atração o Pavilhão Anti-Comunista, onde se acha exposta farta documentação organizada diretamente pelo Ministerio da Justiça, e que impressiona realmente pelo mal informado sobre o comunismo. Ao centro desse pavilhão ergue-se uma coluna votiva, em homenagem a memoria dos militares sacrificados em 27 de novembro de 35 , na defesa do regime. ${ }^{283}$

A imagem registrada pelo Jornal do Brasil e relacionada com a notícia, mostrava em destaque a construção feita pelo Estado Novo:

282 "As realizações do governo do Sr. Getúlio Vargas" In: A Noite. Rio de Janeiro, 24 de novembro de 1938, p. 01. 283 "Exposição Nacional do Estado Novo. O pavilhão anti-comunista". In: Jornal do Brasil. Rio de Janeiro, 13 de dezembro de 1938. p. 7. 


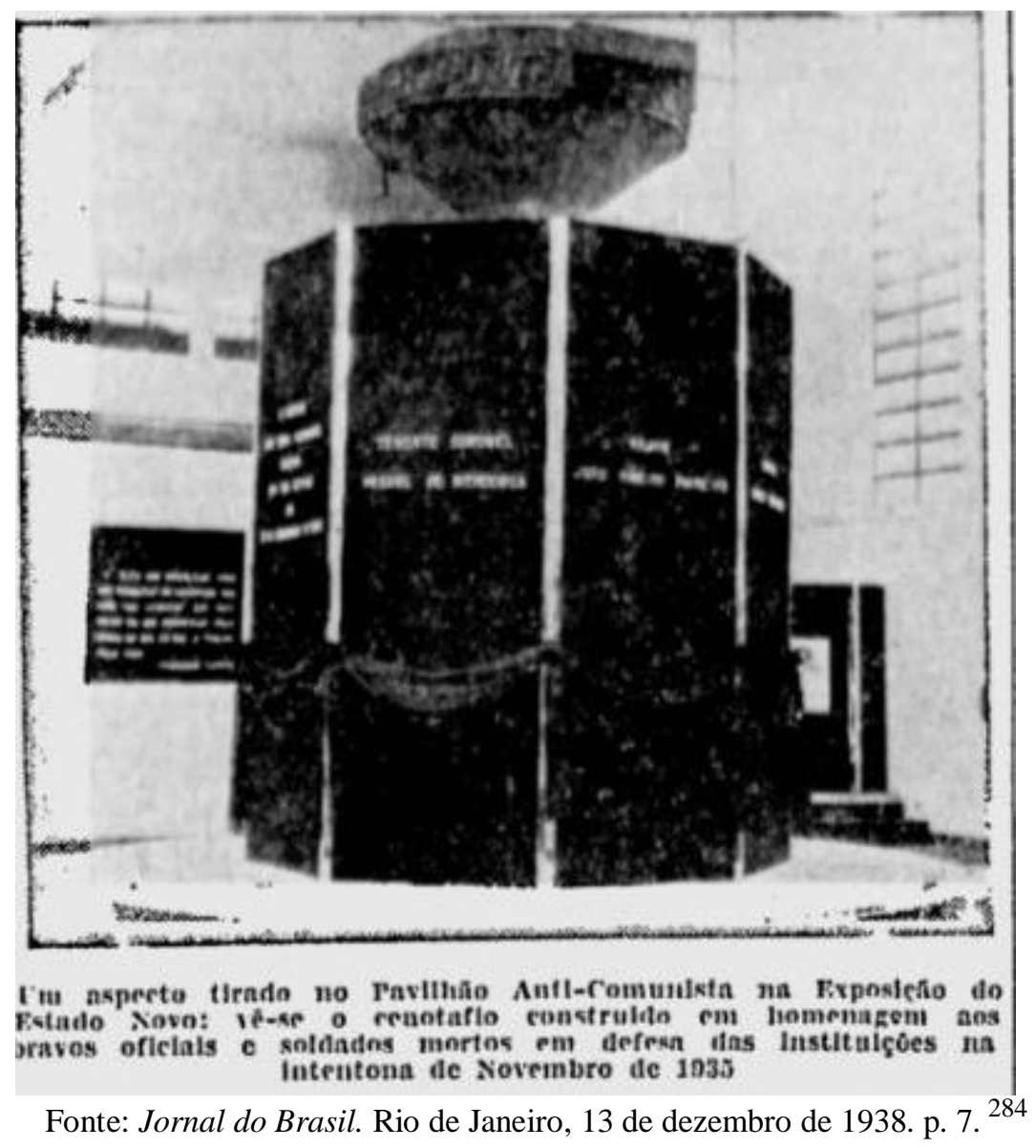

A legenda da imagem relacionava-se com a visão estadonovista sobre a Revolução de 1935. E, coadunava-se com o posicionamento de um dos idealizadores da Exposição, o ministro da Justiça, Francisco Campos. A oficialização do evento como de expressão do anticomunismo do período varguista pode ser observada na nota enviada pelo Interventor Ernani do Amaral ao jornal Gazeta de Notícias em 5 de novembro de 1938:

O Sr. Prefeito, attendendo á solicitação feita pelo Sr. Ministro da Justiça, determinou providencias para que até o dia 20 do mez corrente, sejam entregues áquelle Ministerio, os pavilhões da Feira de Amostras, onde serão instalados os trabalhos da Exposição Anti-Communista e de Obras e Realizações do Presidente Getulio Vargas. ${ }^{285}$

Em 23 dezembro de 1938, quinze dias após o início da Exposição Anticomunista, José Prieto Del Rio, Encarregado de Negócios da Segunda República, direcionou, como não poderia

\footnotetext{
${ }^{284}$ A imagem possui a seguinte legenda: "Um aspecto tirado no Pavilhão Anti-Comunista na Exposição do Estado Novo: vê-se o cenotafio construído em homenagem aos bravos oficiais e soldados mortos em defesa das instituições na Intentona de Novembro de 1935".

285 “Os pavilhões da Feira de Amostras vão ser entregues ao Ministerio da Justiça” In: Gazetas de Noticias. Rio de Janeiro, 05 de novembro de 1938, p. 02.
} 
ser diferente, suas críticas aos materiais da exposição. É ignorado se ele tinha conhecimento de que a solicitação do envio do material havia partido do próprio governo brasileiro. No entanto, ele analisou e apontou diversos elementos, tanto em relação ao grafismo, quanto às afirmações de tal exposição que estavam direcionadas à situação espanhola.

Ao visitar a seção anticomunista da Exposição do "Estado Novo", um visitante insuficientemente informado sobre os acontecimentos da Espanha, sairá com a impressão de que a República Espanhola é um Estado comunista e que promoveu ou tolerou os fatos que se tratam de provar à base de uma documentação que não oferece nenhuma garantia de autenticidade. ${ }^{286}$

Um dos excertos da resposta do governo brasileiro às reclamações de Prieto Del Rio, o colocava em uma situação delicada pela constante negação do governo republicano em relação à participação do comunismo, principalmente por meio da União Soviética, no conflito espanhol:

Informa o Senhor Ministro da Justiça que os documentos exibidos no Pavilhão Anti-Comunista da Exposição do Estado Novo se referem, como aliás, reconhece a própria Legação espanhola na reclamação que nos dirigiu, atentados perpetrados na Espanha por elementos comunistas, à revelia do Govêrno espanhol..$^{287}$

E o governo brasileiro, enquanto permitia a livre circulação de donativos de particulares para os conservadores e militares espanhóis, fazia questão de salientar que as ações de Socorro Vermelho eram danosas:

O Socorro Vermelho serve-se, porém da generosidade dos povos latinoamericanos e de sua simpatia pelo heroico povo da Espanha para, sob o disfarce de obras filantrópicas, exercer a sua ação dissolvente. (...) Tais abusos se verificam múltiplas vezes com referência a obras de beneficência de outra espécie, sem que com isso seja atingido o bom nome da sociedade ou da associação de cujo nome se abusa. ${ }^{288}$

A citação do "Socorro Vermelho" à ajuda nas áreas republicanas foi extraída de sua própria iniciativa de envio de ajuda. Embora a ajuda comunista fosse desassociada de outras formas de "auxílio à Espanha Republicana", a comunicação do governo brasileiro mantinha

\footnotetext{
286 "Memorandum". Da Embaixada da Espanha (Brasil) ao Ministério de Relações Exteriores do Brasil. 23/12/1938. AHI.

287 "Exposição do Estado Novo. Reclamação da Embaixada da Espanha". Da Secretaria de Relaciones Exteriores do Brasil ao Sr. José Prieto del Rio, Encarregado de Negócios interino da Espanha. 26/12/1938, p. 1. AHI.

${ }^{288}$ Ibidem. p.2. AHI.
} 
como uma estratégia de desestruturação social de um Estado espanhol em guerra. Inclusive, expondo que essa ação estava espalhada, ao menos pelo Cone Sul do continente americano:

Em Buenos Aires e em Montevidéo as seções do Socorro Vermelho destinadas a angariar donativos que dizem ser para a Espanha Republicana, são particularmente ativas. ${ }^{289}$

Claramente a recepção do comunicado brasileiro foi tratada como um atestado do completo abandono dos republicanos por parte do governo brasileiro:

Não posso considerar como satisfatória a explicação e o resultado obtido quase ao final da Exposição. Essa atitude de um Centro Oficial, a respeito à Espanha, republica demonstra minha constante afirmação de que grande parte da Administração nos é hostil; mas, acredito que nas circunstâncias presentes, não é possível obter mais, dada a tendência da política interior do Brasil a uma influência a cada dia maior do Exército e da Igreja. ${ }^{290}$

Com o fim da Exposição Anticomunista em 25 de dezembro, os questionamentos acerca da exibição apresentada, que era notadamente contra o governo republicano, são os derradeiros direcionados ao Itamaraty. Em fevereiro de 1939, as articulações para o reconhecimento do governo de Franco estão sobre a mesa de Getúlio Vargas.

\subsection{O fim da Guerra Civil Espanhola: o reconhecimento e a retomada do comércio hispano-brasileiro}

Em fevereiro de 1939, Ciro de Freitas Vale comunica a Getúlio que o embaixador brasileiro na Argentina, Rodrigues Alves, havia recebido um chamado do Ministério das Relações Exteriores da Argentina, para tratar do processo de reconhecimento do governo do General Franco. Os argumentos utilizados pela chancelaria argentina substanciavam-se na tentativa de fazer uma declaração conjunta de parte dos países da América do Sul, ou seja, que,

(...) na próxima segunda-feira, dia 20, e buscava o acôrdo do Brasil, do Uruguai, do Paraguai e da Bolívia, a fim de que esse ato fosse realizado em conjunto. E, na justificativa fornecida, que um apoio dessa envergadura (...) era justificado pela convicção de que o reconhecimento do General Franco sería de molde a desanimar a resistência do Govêrno republicano. ${ }^{291}$

\footnotetext{
289 "Exposição do Estado Novo. Reclamação da Embaixada da Espanha". Da Secretaria de Relaciones Exteriores do Brasil ao Sr. José Prieto del Rio, Encarregado de Negócios interino da Espanha. 26/12/1938, p.2. AHI

290 “Información Política” Do Encarregado de Negócios do governo republicano, José Prieto del Rio, ao Ministro de Estado (Barcelona). 31/12/1938. AMAE

${ }^{291}$ Carta de Ciro de Freitas Vale a Getúlio Vargas, 17/02/1936. GV c. 1936.02.07, volume XXXI/32, p.1.
} 
Em reposta a Rodrigues Alves, Freitas Vale, expõe que os argumentos do governo argentino para que fosse definido um apoio às forças franquistas eram pífias. E que não iria interferir em um caso ultramarino, pois, como havia declarado anteriormente a outros Estados americanos,

(...) o Brasil esperaria a solução européia de um caso nitidamente europeu, isto é, aguardaria o resultado dos esforços atualmente desenvolvidos pela GrãBretanha e pela França para então tomar decisão definitiva sobre o assunto. ${ }^{292}$

E, no momento em que o Brasil reconhecesse o governo de Franco, essa declaração estaria de acordo com os arranjos feitos com os Estados Unidos, fato que a Argentina já possuía conhecimento, pois

(...) quando fôr oportuno, reconhecer o Gôverno do General Franco, mas que antes nos concertaremos, conforme combinação feita por ocasião da visita do Ministro Cantilo, com o Gôverno dos Estados Unidos da América. ${ }^{293}$

Entre 18 de fevereiro e $1^{\circ}$ de março, o Itamaraty iniciou uma série de consultas sobre o processo de reconhecimento apresentado por Cárcer y Lassance. A solicitação do representante do Gobierno de Burgos era incisiva:

Depois de quase três anos de luta ininterrupta, o Governo Nacional da Espanha ocupa hoje uma posição tão predominante e sólida, que, assim havendo compreendido a grande maioria dos países europeus, com eles mantém relações diplomáticas.

(...)

O Governo Nacional da Espanha tem todas as características de um Governo legal e preenche todos os preceitos do Direito Internacional. ${ }^{294}$

As condições para que isso acontecesse, de acordo com documento enviado às missões brasileiras no exterior, eram bastante claras. O telegrama timbrado como "Reservado", afirmava que:

(...) desejo comunicar que o Govêrno nacionalista da Espanha voltou a solicitar formalmente seu reconhecimento pelo do Brasil. Nada se opõe em princípio a tal reconhecimento uma vez que o General Franco consiga vitória

\footnotetext{
${ }^{292}$ Carta de Ciro de Freitas Vale a Getúlio Vargas, 17/02/1936. GV c. 1936.02.07, volume XXXI/32, p.2.

${ }^{293}$ Ibidem.

${ }^{294}$ Carta de José de Cárcer y Lassance (Rio de Janeiro) ao Ministro de Relações Exteriores do Brasil. 16/02/1939, p. 01. AHI
} 
completa, ou coisa que seria de desejar, tenham resultado esforços pacificadores atualmente desenvolvidos pela Grã-Bretanha e pela França. ${ }^{295}$

Em 24 de fevereiro, Vargas já havia resolvido pelo reconhecimento do governo do General Franco, inclusive com o apoio de um de seus principais interlocutores, Oswaldo Aranha, que em 1939 era embaixador nos Estados Unidos:

Estou inteiramente de acordo com o ponto de vista do Presidente da República, cabendo-nos, porém, o resguardo, da melhor forma possível, da situação dos asilados na nossa Embaixada. ${ }^{296}$

O recebimento das chaves entregues da repartição diplomática espanhola no Rio de Janeiro foi feito pelo chefe interino de Gabinete do Ministro de Relações Exteriores. Em suma, o governo republicano espanhol terminou pelas mãos de funcionários do segundo escalão do Itamaraty. No mesmo $1^{\circ}$ de março de 1939 , o governo brasileiro oficialmente reconheceu o novo Estado franquista.

Em resposta, é-me grato comunicar a V.S. que, diante das seguranças apresentadas pelo Govêrno Nacional quanto à extensão da autoridade permanente e efetiva que exerce sôbre grande parte do território espanhol e na esperança de assim apressar o fim da guerra civil, transmiti hoje à Embaixada do Brasil em Portugal instruções no sentido de comunicar oficialmente à Embaixada nacionalista em Lisbôa o reconhecimento por parte do Brasil do Govêrno presidido pelo General Francisco Franco. ${ }^{297}$

Com o fim da Guerra Civil Espanhola, em $1^{\circ}$ de abril de 1939, o governo comandando pelo General Franco começou uma ofensiva diplomática para assegurar a legitimidade do seu governo constituído. Por um lado, essa ação já havia começado nas semanas anteriores ao fim das ações militares, com a assinatura de uma série de tratados com os países que haviam apoiado o levante em 1936. Dessa forma, em 17 de março já havia assinado o Tratado HispanoPortuguês de Amizade de Não-Agressão; aderiu ao Pacto Antikominterm, em 27 de março, e ao Pacto Hispano-Germanico de Amizade e Não-agressão, em 31 de março de 1939.

\footnotetext{
295 "Reconhecimento do Govêrno da Espanha Nacionalisa". Do Ministério de Relações Exteriores às missões diplomáticas brasileiras. 22/02/1939. AHI

296 Correspondência de Oswaldo Aranha, embaixador em Washigton D.C e o Ministro Cyro de Freitas Valle. 24/02/1939. AHI

297 "Reconhecimento do Govêrno Nacionalista da Espanha". Da Secretaria de Estado as Relações Exteriores (Rio de Janeiro) ao Snr. José de Cárcer y Lassance, Representante do Govêrno Nacional de Espanha. 01/03/1939. AHI
} 
Com o fim dos conflitos militares ao final de março de 1939, o Itamaraty enviou ao Encarregado de Negócios do Estado franquista, Cárcer y Lassance, uma solicitação do reconhecimento dos agentes consulares no território espanhol:

Não estando ainda instalada a Missão diplomática do Brasil junto ao Govêrno Nacional da Espanha e até que sejam encaminhadas as respectivas Cartaspatentes para a solicitação do "exequatur" do estilo, muito agradecerei a Vossa Senhoria o obséquio de solicitar do seu Govêrno o reconhecimento provisório dos (...) agentes consulares brasileiros na Espanha. ${ }^{298}$

Com o fim da Guerra Civil Espanhola e a retomada das relações diplomáticas e comerciais de modo pleno, Brasil e Espanha começaram a agir de forma que houvesse uma aceleração na aproximação entre os dois países.

Para o Brasil, o estabelecimento de contatos comerciais com o governo franquista permitia reestruturar tanto o comércio geral entre as duas partes, quanto, especificamente, o de café. Tanto que uma das estratégias iniciais do governo brasileiro foi a manutenção de práticas que foram recorrentes durante a Guerra Civil, sobretudo as de doações de café.

Logo em maio de 1939, o governo brasileiro ofereceu uma nova doação de 10.000 sacas de café, nos mesmos moldes daquelas que haviam ocorrido entre 1937 e 1938:

Recebi uma comunicação escrita deste Departamento Nacional de Café na qual me diz que o Presidente da República, Senhor Getúlio Vargas, ordenou que seja feito um donativo de 10.000 (dez mil) sacos de café ao nosso governo para que o partilhe como estime oportuno, dispondo assim mesmo que todos os gastos, inclusive o frete, ocorram por conta do mencionado Departamento. ${ }^{299}$

Embora o formato de remessa dos donativos fosse o mesmo, inclusive em seu conteúdo, com a carta de maio de 1939 reafirmando a divisão dos envios em três embarques diferentes, com os encargos abatidos pelo DNC, nota-se na própria documentação que não existem mais as antigas restrições de circulação diplomática. Ao contrário do que ocorreu no percurso do conflito interno espanhol, as doações pós-Guerra Civil foram públicas e sem rubricas que as classificassem como reservadas ou secretas, como foi comum entre agosto de 1936 e março de 1939.

298 "Reconhecimento provisório dos Consules brasileiros na Espanha". Da Secretaria de Estado as Relações Exteriores (Rio de Janeiro) ao Senhor José Cárcer y Lassance (Rio de Janeiro). 31/03/1939. AHI.

299 "Donativo 10.000 sacos café". De José de Carcer, Encargado de Negocios de España (Rio de Janeiro), al Ministro de Asuntos Exteriores (Burgos). 17/05/1939. AGA. 
No entanto, é necessário notar que os atos de "boa-fé" para auxiliar os espanhóis com necessidades possuíam uma objetivação. Os motivos da continuidade das doações de café se encaixavam na necessidade de se manter as exportações da principal mercadoria brasileira. E, com o pleno domínio do franquismo em território espanhol e o seu reconhecimento, por parte do governo brasileiro, haveria a constituição de um novo nicho nas exportações nacionais.

Tanto que se observarmos o Gráfico 3.1, é perceptível o crescimento na tonelagem das exportações ao Estado espanhol.

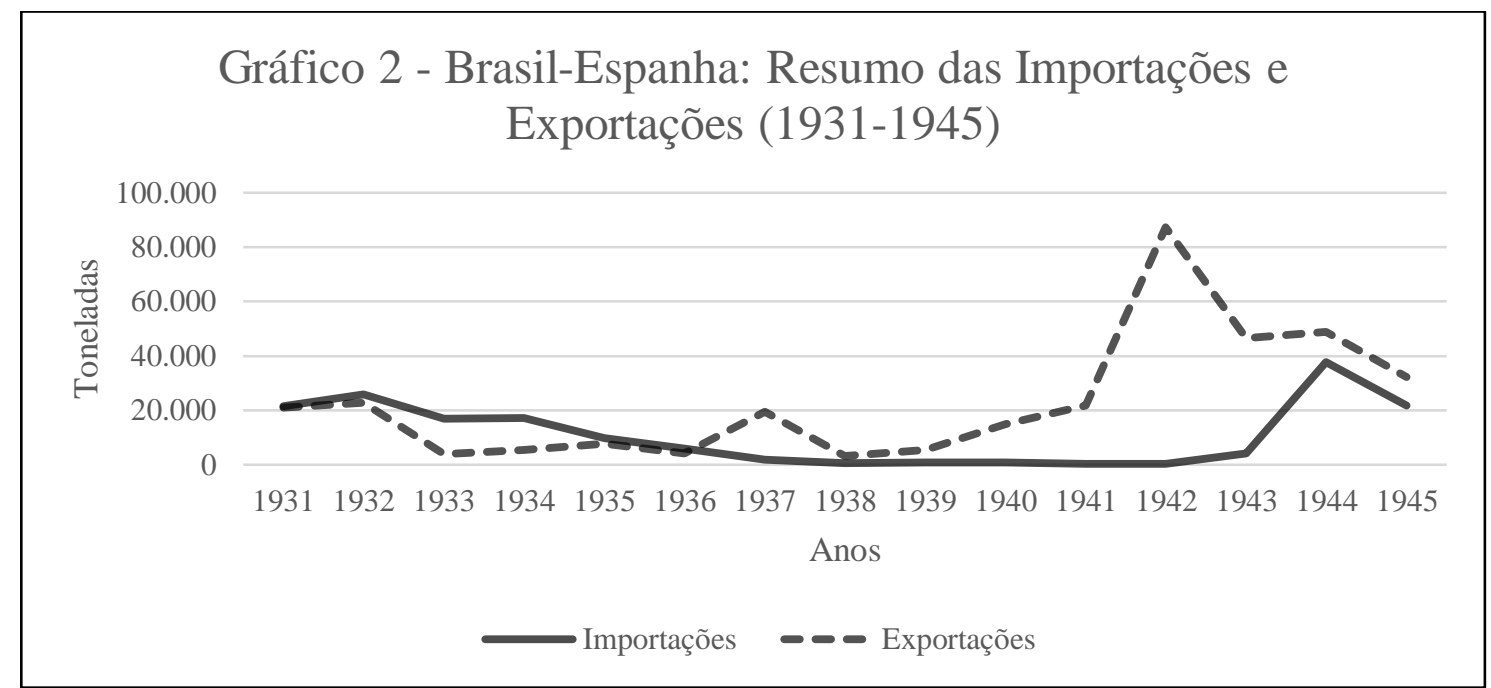

Fontes: BRASIL. MINISTÉRIO DA FAZENDA. SERVIÇO DE ESTATÍSTICA ECONÔMICA E FINANCEIRA DO TESOURO NACIONAL. Quadros Estatísticos. No. 2-Q.E.A. 1930-1937. Rio de Janeiro: Imprensa Nacional, 1940, p. 37; BRASIL. MINISTÉRIO DA FAZENDA. SERVIÇO DE ESTATÍSTICA ECONÔMICA E FINANCEIRA DO TESOURO NACIONAL. Quadros Estatísticos. 1937-1946. Rio de Janeiro: Imprensa Nacional, 1949, pp. 12;14.

A trajetória do comércio geral entre os dois países, que foi parcialmente abordada no decorrer desta pesquisa, apontou que desde 1931 houve um constante declínio das importações brasileiras desde o Estado espanhol. O nadir dessa trajetória foi em 1941, com a chegada de apenas 311 toneladas, com um valor bem abaixo, mesmo com a Guerra Civil em curso, do que havia ocorrido em 1938, com 551 mil quilos. ${ }^{300}$ Essa diminuição do fluxo exportado para o Brasil, pode ser explicado a partir das próprias consequências do efeito devastador do conflito intestino espanhol, que pôs as condições materiais e humanas, do então atrasado capitalismo espanhol, em condições ainda mais deletérias. A lenta trajetória de recuperação das exportações da Espanha franquista somente alcançaria um patamar superior ao de 1931, em 1944 com um total de 37.735 toneladas. $^{301}$

\footnotetext{
${ }^{300}$ BRASIL. MINISTÉRIO DA FAZENDA. SERVIÇO DE ESTATÍSTICA ECONÔMICA E FINANCEIRA DO TESOURO NACIONAL. Quadros Estatísticos. 1937-1946. Rio de Janeiro: Imprensa Nacional, 1949, p. 12. 301 Ibidem.
} 
Em relação às exportações nacionais para o território espanhol, entre 1937 e 1945, a balança comercial havia se tornado favorável ao Brasil. Com exceção de um pico em 1937, devido ao envio de grandes quantidades de carne ao governo republicano, o volume de exportações brasileiras teve um ascendente que alcançou um pico de 87.315 toneladas de produtos ao território espanhol. Um pouco mais que o montante de 86.189 toneladas, ou seja, a quantidade total do que o Brasil havia exportado à Espanha desde $1933 .{ }^{302} \mathrm{E}$, mesmo com uma queda nos dois anos seguintes, o volume de exportações brasileiras, superou o de importações.

No caso específico do café, o carro-chefe de ajuda do Estado Varguista aos militares revoltosos de 1936, com o fim da Guerra Civil, houve um grande incremento no volume das exportações para a Espanha, de sobremaneira entre 1941 e 1943:

\begin{tabular}{|c|c|c|c|c|c|c|c|}
\hline \multicolumn{7}{|c|}{ 3.2 Exportação de Café para a Espanha (1939-1945) } \\
\hline Anos (Ano-calendário) & $\mathbf{1 9 3 9}$ & $\mathbf{1 9 4 0}$ & $\mathbf{1 9 4 1}$ & $\mathbf{1 9 4 2}$ & $\mathbf{1 9 4 3}$ & $\mathbf{1 9 4 4}$ & $\mathbf{1 9 4 5}$ \\
\hline Sacas de 60 kg & 11.253 & 5.339 & 82.628 & 110.892 & 183.502 & 69.493 & 2.610 \\
\hline
\end{tabular}

Fontes: BRASIL. DEPARTAMENTO NACIONAL DO CAFÉ. SECÇÃO DE ESTATÍSTICA. Anuário Estatístico do Café, 1943/1945. Rio de Janeiro, 1946, p. 323; BRASIL. SECRETARIA DA FAZENDA DO ESTADO DE SÃO PAULO. SUPERINTENDÊNCIA DOS SERVIÇOS DO CAFÉ. Anuário Estatístico 1954/1956. São Paulo: Departamento Estatística e Publicidade da SSC - São Paulo, 1956, p. 63.

Enquanto no campo econômico, as relações entre o Brasil e Espanha cresciam paulatinamente, no campo político, elas foram balizadas pelos efeitos da Segunda Guerra Mundial.

\footnotetext{
${ }^{302}$ BRASIL. MINISTÉRIO DA FAZENDA. SERVIÇO DE ESTATÍSTICA ECONÔMICA E FINANCEIRA DO TESOURO NACIONAL. Quadros Estatísticos. No. 2-Q.E.A. 1930-1937. Rio de Janeiro: Imprensa Nacional, 1940, p. 37; BRASIL. MINISTÉRIO DA FAZENDA. SERVIÇO DE ESTATÍSTICA ECONÔMICA E FINANCEIRA DO TESOURO NACIONAL. Quadros Estatísticos. 1937-1946. Rio de Janeiro: Imprensa Nacional, 1949, p. 12;14.
} 


\section{Considerações Finais}

Entre os anos de 1939 e 1941, as relações entre os dois países não foram abaladas pela condição que o Estado espanhol se encontrou a partir de setembro de 1939, com o avanço do Eixo pelo continente europeu e do teatro de operações do Oriente.

Com a declaração de guerra realizada pelos Estados Unidos, em dezembro de 1941, contra os japoneses e sua entrada no front europeu no ano seguinte, o Estado espanhol é posto no mesmo patamar que as outras nações do Eixo. Enquanto que até o fim da Guerra Civil, as preocupações do governo Roosevelt se dirigiam às suas ações com os governos latinoamericanos, com a expansão da Segunda Guerra ao Atlântico Norte, os Estados Unidos tomam preocupações adicionais tanto frente à política externa espanhola, bem como a interna.

De forma correlata, as relações hispano-brasileiras, ao menos no campo político, se alteraram. A partir das resoluções assumidas na III Reunião de Consulta dos Ministros de Relações Exteriores das Repúblicas Americanas, realizada no Rio de Janeiro, entre 18 e 25 de janeiro de 1942, que aprovou uma resolução que recomendava o rompimento das relações com os países do Eixo, a Espanha franquista entrou na alça de mira dos Estados Unidos. Em um momento em que o governo brasileiro estabelecia também o seu alinhamento junto ao governo Roosevelt, as relações políticas hispano-brasileiras entraram na berlinda.

A situação de controle que o Estado espanhol passou a sofrer a partir de 1942, foi potencializado quando o governo brasileiro rompeu suas relações com os países do Eixo e a Espanha franquista ficou no encargo de atender pelos interesses diplomáticos e consulares de Alemanha, Itália e, em menor escala Japão. De forma associada ao seu papel diplomático nas relações entre o Eixo e o governo brasileiro, órgãos internos da política franquista tomaram dimensões planetárias. Esse foi o caso da Falange, que havia se tornado o partido único, ainda em fins de 1937, e era apresentada como sendo um instrumento político que apresentou suporte tanto aos espanhóis, bem como de outros nacionais do Eixo.

Em 1942, o Estado espanhol encontrava-se isolado das relações na arena internacional e com sérias dificuldades para recuperar-se dos resultados materiais e humanos do conflito terminado três anos antes. Na mesma situação, estavam as forças de propaganda do regime franquista, principalmente aquelas que agiram no continente americano.

Com esse cenário desfavorável, tem-se a proposta de uma alteração na forma de ação da Falange nas Américas, ou seja, ao invés da exposição é preferível que os agentes da Falange 
tenham uma ação discreta, tanto que o boletim de instrução para a Falange afirma que, "O lema ‘Agredir para vencer', será substituído por Discrição para vencer’”.303

De acordo com um boletim de instrução da Falange Española:

(...) perante as circunstancias especialmente difíceis pelas quais passam nosss organizações de propaganda e combate na América, perseguida por certos governos a serviço do judaísmo internacional, ficam interrompidas até novo aviso nossas relações ordinárias e proibidas as visitas aos escritórios, pontos de reunião, embora continuem abertos com fins puramente comerciais. ${ }^{304}$

Embora o trecho não especifique diretamente quais governos que atacavam as seções locais da Falange, ao levarmos em consideração o cenário existente, certamente os Estados Unidos eram um deles.

Ao abordar as práticas partidárias e de seu líder Serrano Suñer, o Cuñadisímo, este era visto pelas agências de vigilância militar dos Estados Unidos como o articulador do partido do papel da Falange, tanto em suas ações internas, como nas externas:

Suporte do Eixo, com a falta de um programa político alternativo entre os apoiadores de Franco e das habilidosas manobras de Serrano Suñer fizeram o Partido, que acredita no totalitarismo internamente e no imperialismo no estrangeiro, um ativo participante em quase todas as fases da vida espanhola. Por causa de que alguns de seus membros são suspeitos de deslealdade, as atividades do Partido estejam sendo impopulares em certos níveis e porque a Alemanha deseja manter o prestigio da Falange alto, existe agora um extensivo processo de expurgo do Partido. ${ }^{305}$

Embora considerassem o Estado espanhol pró-Eixo, também foram expostas a delicadeza e o frágil equilíbrio do cenário interno espanhol, com uma população ainda dividida ideologicamente no mesmo diapasão que durante a Guerra Civil Espanhola. Ademais, os papéis dúbios das potências de vieses democráticos e das ações militares desempenhadas pela aliança ítalo-germânica de apoio aos militares revoltosos se entrelaçavam com a situação espanhola no começo dos anos de 1940:

\footnotetext{
${ }^{303}$ Boletin extraordinario de Instrucciones de la Falange, 02/1942. GV c 1942.02.00, volume XXXVII/3, p.2.

304 Ibidem. p.1.

305 COORDINATOR OF INFORMATION. Western European Section. Memorandum No 5. “THE FALANGE PARTY OF SPAIN. December 15, 1941 (NARA/II). O Coordinator of Information foi o orgão de informação e espionagem criado em julho de 1941 e serviu como o passo inicial para a criação do Office of Strategic Services (OSS). A OSS se tornou, durante a Segunda Guerra, o departamento de inteligência do governo norte-americano e que proveu informações tanto sobre países do Eixo e da União Soviética, bem como deu suporte aos diversos movimentos partisans durante o conflito. Em setembro de 1945 a OSS foi extinta com a criação da Central Intelligency Agency (CIA).
} 
A Espanha "oficial”, particularmente a imprensa, rádio e Suner, é pró-Eixo. As classes superiores temem uma vitória das Nações Unidas que podem significar o retorno do republicanismo, que eles temem. O resto das pessoas tem aversão ao Eixo, embora não amem os Aliados. Eles não esqueceram que Alemanha e Itália interviram contra eles na guerra civil e que as grandes democracias não vieram em sua ajuda. Acima de tudo, o povo da Espanha quer evitar posteriores discórdias e sofrimentos; mas a promessa de comida, trabalho e a liquidação da Falange, seja qual for a sua origem, poderia ser muito atraente. ${ }^{306}$

A tênue linha de equilíbrio que envolvia os interesses, principalmente comerciais do Brasil na Espanha franquista e o papel de principal aliado dos Estados Unidos no âmbito continental, tem que ser plenamente considerado. E, mesmo que a influência dos Estados Unidos nas relações hispano-brasileiras não seja o escopo desse trabalho, a presença da Falange, o papel da colônia espanhola e as relações bilaterais são ainda objeto de estudos que precisam ser abordados.

Abordar a finalização de uma pesquisa a respeito da Guerra Civil Espanhola, sejam quais forem os temas e problemáticas adotadas, ainda que de 80 anos depois do seu término, é um problema em si. Distante de qualquer relativismo a ser considerado, o problema reside em quantidade gigantesca de documentos existentes, nos mais distantes rincões do planeta e numa vasta gama de idiomas.

Dentro das dificuldades inerentes ao tema, o que apresentamos em nosso trabalho foi o quadro, talvez inicial, das relações entre as estruturas e órgãos estatais brasileiros e os sublevados espanhóis a partir da sua representação centrada no Rio do Janeiro e com tentáculos por todo o país, que visavam a legitimação do golpe de estado realizado por militares a partir de julho de 1936. Como afirmado no decorrer deste trabalho, havia uma visão hegemônica na historiografia sobre os limites de se investigar tal tema, principalmente por não terem sido localizadas fontes documentais que sustentassem maior aprofundamento. No entanto, o processo de pesquisa em diversos arquivos mostrou a existência de farta documentação sobre a interferência e, sobretudo, o apoio de elementos do governo brasileiro em advogar e apoiar materialmente os militares revoltosos espanhóis.

Dessa forma, por meio de subterfúgios e percursos alternativos entre o ano de 1936 e 1938, houve o apoio sistemático do Estado brasileiro ao comando do General Francisco Franco. Uma sustentação que envolveu tanto o envio e a facilitação de diversas remessas de café, o suporte ao envio de doações diretas por meio de Portugal, mesmo no decorrer de 1938, quando

306 COORDINATOR OF INFORMATION. Psychology Division. Divisional Report N ${ }^{\mathrm{o}} 15$. "CURRENT ATTITUDES IN SPAIN". March 12, 1942. Summary. NARA/II 
do início do afastamento do governo brasileiro dos países nazifascistas. Tanto que de forma concomitante, o governo brasileiro solicitou o apoio dos representantes da Junta Nacionalista Española en el Brasil.

Certamente, aqueles que abordarem esse trabalho, vão localizar lacunas, que podem provocar uma "famosa" pergunta: E o papel de Getúlio Vargas?

Como outros pesquisadores que abordaram o tema anteriormente, não foi possível localizar e analisar, por meio de fontes documentais, sua interferência pessoal e direta. É indubitável que a ausência, dentro de um cenário, principalmente a partir de 1937, onde a centralidade do Estado se consolidou nele, cause estranheza. Mas a princípio, os agradecimentos que aparecem em seu nome possuem um caráter mais voltado à administração do que à própria pessoa. Nenhum documento apresentou comentários ou posicionamentos sobre a ajuda aos rebelados, a não ser a respeito do posicionamento e os conflitos no interior do governo brasileiro. Ao menos, por enquanto... 


\section{CORPO DOCUMENTAL}

\section{- FONTES IMPRESSAS}

ACHESON, Dean. Present At The Creation: My years in the State Department. New York: Signet, 1970.

AZAÑA, Manuel. Diarios Completos: Monarquía, República, Guerra Civil. Barcelona: Crítica: 2000.

BERLE, Adolf A. Navigating the rapids, 1918-1971; from the papers of Adolf A. Berle. $1^{\text {st }}$ ed. New York: Harcourt Brace Jovanovich, 1973.

BRASIL. DEPARTAMENTO NACIONAL DO CAFÉ. SECÇÃO DE ESTATÍSTICA. Anuário Estatístico do Café, 1939/40. Rio de Janeiro, 1941.

BRASIL. Instituto Brasileiro de Geografia e Estatística. Repertório Estatístico do Brasil. Quadros Retrospectivos no. 1 (Separata do Anuário Estatístico do Brasil - Ano V - 1939/1940). Rio de Janeiro: Serviço Gráfico do Instituto Brasileiro de Geografia e Estatística, 1941. BRASIL. MINISTÉRIO DA FAZENDA. SERVIÇO DE ESTATÍSTICA ECONÔMICA E FINANCEIRA DO TESOURO NACIONAL. Quadros Estatísticos. No. 3-Q.E.A. 1932-1939. Rio de Janeiro: Imprensa Nacional, 1940.

BRASIL. MINISTÉRIO DAS RELAÇÕES EXTERIORES. MINISTRO (JOSÉ CARLOS DE MACEDO SOARES). Relatório apresentado ao Dr. Getúlio Vargas, Presidente dos Estados Unidos do Brasil pelo Ministro de Estado de Relações Exteriores. Rio de Janeiro: Imprensa Nacional, 1936. 2 vols.

BRASIL. MINISTÉRIO DAS RELAÇÕES EXTERIORES. MINISTRO (MÁRIO DE PIMENTEL BRANDÃO). Relatório apresentado ao Dr. Getúlio Vargas, Presidente dos Estados Unidos do Brasil pelo Ministro de Estado de Relações Exteriores. Rio de Janeiro: Imprensa Nacional, 1937. 2 vols.

BRASIL. MINISTÉRIO DAS RELAÇÕES EXTERIORES. Relatório apresentado ao Dr. Getúlio Vargas, Presidente dos Estados Unidos do Brasil pelo Ministro de Estado de Relações Exteriores. Rio de Janeiro: Imprensa Nacional, 1938.

BRASIL. MINISTÉRIO DAS RELAÇÕES EXTERIORES. MINISTRO (OSWALDO EUCLIDES DE SOUZA ARANHA) Relatório apresentado ao Presidente dos Estados Unidos do Brasil pelo Ministro de Estado de Relações Exteriores. Relativo ao ano de 1939. Rio de Janeiro: Imprensa Nacional, 1943. 
BRASIL. MINISTÉRIO DAS RELAÇÕES EXTERIORES. MINISTRO (OSWALDO EUCLIDES DE SOUZA ARANHA) Relatório apresentado ao Presidente dos Estados Unidos do Brasil pelo Ministro de Estado de Relações Exteriores. Relativo ao ano de 1940. Rio de Janeiro: Imprensa Nacional, 1943.

BRASIL. MINISTÉRIO DAS RELAÇÕES EXTERIORES. MINISTRO (OSWALDO EUCLIDES DE SOUZA ARANHA) Relatório apresentado ao Presidente dos Estados Unidos do Brasil pelo Ministro de Estado de Relações Exteriores. Relativo ao ano de 1941. Rio de Janeiro: Imprensa Nacional, 1943.

BRASIL. MINISTÉRIO DAS RELAÇÕES EXTERIORES. MINISTRO (OSWALDO EUCLIDES DE SOUZA ARANHA) Relatório apresentado ao Presidente dos Estados Unidos do Brasil pelo Ministro de Estado de Relações Exteriores. Ano de 1942. Rio de Janeiro: Imprensa Nacional, 1944.

BRASIL. MINISTÉRIO DAS RELAÇÕES EXTERIORES. MINISTRO (OSWALDO EUCLIDES DE SOUZA ARANHA) Relatório apresentado ao Presidente dos Estados Unidos do Brasil pelo Ministro de Estado de Relações Exteriores. Ano de 1943. Rio de Janeiro: Imprensa Nacional, 1944.

BRASIL. MINISTÉRIO DAS RELAÇÕES EXTERIORES. Relatório apresentado ao Presidente dos Estados Unidos do Brasil pelo Ministro de Estado de Relações Exteriores. Ano de 1944. Rio de Janeiro: Imprensa Nacional, 1949.

CARRERAS, Albert y TAFUNELL, Xavier (Coords.). Estadísticas históricas de España. Siglos XIX-XX. $2^{\mathrm{a}}$.Ed. Bilbao: Fundación BBVA, 2005.

CHURCHILL, Winston S. The Second World War. Londres: Cassell \& Co., 1952.

CUNHA, Vasco Tristão Leitão da. Diplomacia em Alto-mar: depoimento ao CPDOC. $2^{\mathrm{a}}$ ed. Rio de Janeiro: Editora FGV, 2003.

ESPAÑA. Dirección General de Aduanas. Sección de Estadística. Resumen provisional de estadística del comercio exterior: enero a marzo de 1938. Madrid: Sucesores de Rivadeneyera, 1938.

ESPAÑA. Dirección General de Aduanas. Sección de Estadística. Resumen provisional de estadística del comercio exterior: julio a deciembre de 1936. Madrid: Sucesores de Rivadeneyera, 1936.

ESPAÑA. MINISTERIO DE TRABAJO. DIRECCIÓN GENERAL DE ESTADÍSTICA. Anuario Estadístico de España. Madrid, Año XX, 1943. 
ESPAÑA. MINISTERIO DE TRABAJO, SANIDAD, Y PREVISIÓN. SUBDIRECCIÓN GENERAL DE ESTADÍSTICA. Pequeño Anuario Estadístico de España. Madrid: Talleres Tipográficos PLUTARCO, 1936.

GIL ROBLES, José María. No fue posible la paz. Barcelona: Ariel, 2006.

HULL, Cordell. The Memoirs of Cordell Hull. New York: Ed. Macmillan, $19402 \mathrm{v}$.

HULL, Cordell. Addresses and Statements by The Honorable Cordell Hull. Secretary of State of the United States of America. In Connection with His Trip to South America to attend the Inter-American Conference for the Maintenance of Peace held at Buenos Aires, Argentina, December 1-23, 1936. Washington, D.C.: United States Government Printing Office.

NIXON, Edgar B. (editor). Franklin D. Roosevelt and Foreign Affairs. Cambridge: The Belknap Press, 1969. 3 vols.

PORTUGAL. INSTITUTO NACIONAL DE ESTATÍSTICA. Estatística Comercial. Ano de 1936. Importações e Exportações por classe e artigos da pauta. Lisboa: Imprensa Nacional, vol. 1, 1937.

PORTUGAL. INSTITUTO NACIONAL DE ESTATÍSTICA. Estatística Comercial. Ano de 1937. Importações e Exportações por classe e artigos da pauta. Lisboa: Imprensa Nacional, vol. $1,1938$.

ROOSEVELT, Franklin D. The Public Papers and Addresses of Franklin D. Roosevelt. With a Special Introduction and Explanatory notes by President Roosevelt. New York: The MacMillian Company, 1941. 4 vols.

UNITED STATES. Department of State. Foreign Relations of the United States. Europe. 1936.

Washington, D.C.: Government Printing Office, vol. II, 1954.

UNITED STATES, Department of State. Peace and War: United States Foreign Policy, 1931 1941 (Washington, D.C.: U.S., Government Printing Office, 1943.

UNITED STATES, Department of State. Peace and War: United States Foreign Policy, 1931 1941 (Washington, D.C.: U.S., Government Printing Office, 1943.

UNITED STATES. Government Printing Office. Foreign Relations of the United States, 19361945. Washington, DC.

VARGAS, Getúlio. A nova política do Brasil. Rio de Janeiro: Livraria José Olimpio, 19381941, 10 vols.

VARGAS, Getúlio. Diretrizes da nova política do Brasil. Rio de Janeiro: Livraria José Olimpio, 1942. 
VARGAS, Getúlio. 1930-1940, a República dos Estados Unidos do Brasil e o exército brasileiro. Rio de Janeiro: Livraria José Olimpio, 1941.

VERGARA, L., Fui secretário de Getúlio Vargas. Porto Alegre: Ed. Globo, 1960.

WELLES, Summer. Dias Decisivos. Rio de Janeiro: Empresa Gráfica “O Cruzeiro”, 1945.

WELLES, Summer. The World of The Four Freedoms. New York/Morningside Heights: Columbia University Press, 1943.

\section{- PERIÓDICOS}

Folha Da Manhã

Jornal do Brasil

Gazeta de Notícias

\section{- ARQUIVO HISTÓRICO DO MINISTÉRIO DAS RELAÇÕES EXTERIORES - RIO DE JANEIRO, BRASIL}

Oficio de Alcebíades Peçanha a Pimentel Brandão, "A imprensa e os asylados", n 35. 11/07/1937.

Oficio de Alcebíades Peçanha a Mário de Pimentel Brandão, "O reconhecimento do Governo de Burgos", n 36. 14/07/1937.

Oficio de Alcebíades Peçanha a Mário de Pimentel Brandão "Acontecimentos políticos do Brasil", nº 60. 28/11/1937.

- CPDOC/FUNDAÇÃO GETÚlio VARGAS - RIO DE JANEIRO, BRASIL

“Carta de Oswaldo Aranha a Getúlio Vargas”, GV c 1936.05.00 (Vol. XXII/54). Washington.

“Telegrama de Getúlio Vargas a Oswaldo Aranha”, GV c 1936.08.13 (Vol. XXIII/50). Rio de Janeiro.

“Carta de Getúlio Vargas a Oswaldo Aranha”, OA cp 1936.08.17/1. Rio de Janeiro.

“Carta de Oswaldo Aranha a Getúlio Vargas”, GV c 1936.08.26 (Vol. XXIII/58). Washington

“Telegrama de Alcebíades Peçanha a Getúlio Vargas” GV c 1936.11.07 (Vol. XXIV/55a). Madri 
“Carta de Franscisco Franco a Getúlio Vargas", GV c 1936.10.29/1 (Vol. XXIV/44). Salamanca.

"Carta de Oswaldo Aranha a Getúlio Vargas", GV c 1937.06.04/1 (Vol. XXVI/54). Washington.

“Telegramas entre Oswaldo Aranha e Getúlio Vargas" GV c 1937.07.12 (Vol. XXVI/80a e 80b). Washington, Rio de Janeiro.

“Carta a José Fernandes Alcazar a Oswaldo Aranha” OA cp 1937.09.04/1. sem local.

“Carta de Oscar Correia a Oswaldo Aranha”, OA cp 1939.08.08. Nova Iorque.

“Telegrama de João Batista Luzardo a Getúlio Vargas” GV c 1940.04.03/2 (Vol. XXXIII/68).

Montevidéu.

“Telegramas de Aberlado Roças a Getúlio Vargas”, GV c 1943.02.09 (Vol. XL/21, 25 e Vol. XLI/4). Madrid.

"Discurso no Itamaraty, em homenagem ao embaixador da Espanha, Raimundo Fernandez Cuesta Y Merelo.” OA pi Aranha, O. 1942.11.09. Rio de Janeiro.

“Carta de João Neves a Getúlio Vargas” GV c 1944.02.09/2 (Vol. XLIII/32). Lisboa.

\section{- ARCHIVO GENERAL DE LA ADMINISTRACIÓN (AGA)}

"Los acuerdos comerciales del Brasil actualmente en Vigor." Servicio Comercial del Ministerio de Asuntos Exteriores. 28/09/1934.

“Informe comercial no 31.” Da Camara Oficial Española de Comercio e Industria en Rio de Janeiro al Embajador Español. 16/01/1935.

Informe no 1166-1935. Da Camara Oficial Española de Comercio e Industria en Rio de Janeiro al Embajador Español. 28/10/1935.

Telegrama no. 80656 da Secretaria de Relaciones Exteriores (Salamanca) ao Representante do Governo Nacional no Brasil, Jose de Carcer. 27/06/1937.

"Telegrama Oficial” De Miguel Cabanellas (Burgos) a Eduardo Viñals (Rio de Janeiro). 08/09/1936.

Carta de Luis Viñals y Fons (Rio de Janeiro) ao General Presidente da Junta de Defesa Nacional (Miguel Cabanellas) em Burgos. 30/09/1936.

Carta de Miguel Cordomí (São Paulo) ao Secretario de Estado. Gobierno Nacional de Burgos. 04/11/1936. 
ACTA DE LA CONSTITUCION DE LA “Junta Oficial Nacionalista Española en el Brasil”

“Telegrama Oficial” De Miguel Cabanellas (Burgos) a Eduardo Viñals (Rio de Janeiro). 08/09/1936.

Carta de Luis Viñas (Rio de Janeiro) a José de Carcer y Lassance (Burgos). 03/09/1936.

Carta de Victor Fernández Alonso, da Comisión Nacionalista Española (Rio de Janeiro), al Secretário de Relaciones Exteriores de la Junta Técnica de Defensa, Francisco Serrat y Bonastre (Salamanca). 28/01/1937.

Carta de Julián Chacel al Secretario de Relaciones Exteriores del gobierno del Estado Español (Salamanca), Sr. D. Francisco Serrat. 20/04/1937.

"Informa sobre politica interior y dimisión Ministros Relaciones Exteriores y Justicia”. De José Carcer (Rio de Janeiro) a Francisco Serrat y Bonastre, Secretario de Relaciones Exteriores (Salamanca). 03/01/1937.

Telegrama 87. De Jose Fernández de Carcer, representante do Governo Nacional da Espanha no Brasil, ao Secretario Relaciones Exteriores (Salamanca). 29/11/1937(?). 51/16463.

Carta de Jose de Cárcer, Representante do Governo Nacionalista no Brasil, a Jaime Guedes, presidente do Departamento Nacional do Café, 09/12/1937.

Carta de Jose Fernández de Carcer, representante do Governo Nacional da Espanha no Brasil, ao Almirante Graça Aranha, Diretor do Lloyd Brasileiro. 22/12/1937.

Carta de Jaime Guedes, presidente do Departamento Nacional do Café, a José Carcer, Representante do Govêrno Nacional de Espanha. Rio de Janeiro. 23/12/1937.

Carta de Jaime Guedes, Presidente do Departamento Nacional do Café, a Jose de Carcer, representante do Governo Nacional da Espanha no Brasil. 27/12/1937

Carta de José de Cárcer, representante do Governo Nacional de Espanha, ao Secretario de Relaciones Exteriores. Rio de Janeiro. 30/12/1937.

Carta do Almirante Haroldo de Graça Aranha, Diretor do Lloyd Brasileiro, a Victor Fernandez Alonso, Presidente da "Comision Nacionalista Española”. Rio de Janeiro. 03/01/1938.

“Sobre envio 10 mil sacos de café.”. José de Cárcer (Rio de Janeiro) al Ministro de Asuntos Exteriores (Burgos). 16/11/1938.

"Sobre donativo 10 mil sacas de café. Cruz Roja Norteamericana”. José de Cárcer (Rio de Janeiro) al Ministro de Asuntos Exteriores (Burgos). 06/12/1938.

“Donativo 10.000 sacos café". De José de Carcer, Encargado de Negocios de España (Rio de Janeiro), al Ministro de Asuntos Exteriores (Burgos). 17/05/1939. 


\section{- ARCHIVO DEL MINISTERIO DE ASUNTOS EXTERIORES DE ESPAÑA - MADRI, ESPANHA.}

De Julián Chacel ao General Presidente da Junta de Defesa Nacional (General Miguel Cabanellas) em Burgos. no. 3. 12/08/1936. R/1001(3).

De Julián Chacel ao General Presidente da Junta de Defesa Nacional (General Miguel Cabanellas) em Burgos. no. 4. 20/08/1936. R/1001(3).

De Julián Chacel ao General Presidente da Junta de Defesa Nacional (General Miguel Cabanellas) em Burgos. no. 13. 01/09/1936. R/1001(3).

“Telegrama” Do General Presidente da Junta de Defesa Nacional (General Miguel Cabanellas) em Burgos a Embaixada no Rio de Janeiro (Luis de Viñals y de Fons). 08/09/1936. R/1001(3). Do Segundo Secretário Luis de Viñals y de Fons da Embaixada no Rio de Janeiro ao General Presidente da Junta de Defesa Nacional (General Miguel Cabanellas) em Burgos. 30/09/1936. $\mathrm{R} / 1001(3)$.

"Informa acerca visita Ministro Relações Exteriores do Brasil." Do Representante do Estado Nacional Espanhol no Rio de Janeiro (José de Carcer) ao Secretario de Relaciones Exteriores do Governo do Estado Espanhol (Francisco Serrat y Bonastre) em Burgos. no. 3. 15/12/1936." E/94.

"Acerca reconocimiento beligerancia." Do Representante do Estado Nacional Espanhol no Rio de Janeiro (José de Carcer) ao Secretario de Relaciones Exteriores do Governo do Estado Espanhol em Burgos. no. 87. 06/07/1937.” R/1001 (2)

“Acerca reconocimiento nuestra beligerancia.” Do Representante do Estado Nacional Espanhol no Rio de Janeiro (José de Carcer) ao Secretario de Relaciones Exteriores do Governo do Estado Espanhol em Salamanca. no. 92. 03/08/1937.” R/1001 (2)

"Informa acerca politica interior e exterior del Brasil" Do Representante do Estado Nacional Espanhol no Rio de Janeiro (José de Carcer) ao Secretario de Relaciones Exteriores do Governo do Estado Espanhol em Salamanca. no. 104. 17/08/1937.” R/1001 (2)

"Informe Político" Do Representante do Estado Nacional Espanhol no Rio de Janeiro (José de Carcer) ao Secretario de Relaciones Exteriores do Governo do Estado Espanhol em Salamanca. no. 161. 25/11/1937.” R/1001 (2)

"Informe Político do Encargado de Negócios no Rio de Janeiro (José de Carcer) al Ministro de Asuntos Exteriores em Burgos. no. 46. 31/03/1938." R/1001(3) 
“Informe Político do Encargado de Negócios no Rio de Janeiro (José de Carcer) al Ministro de Asuntos Exteriores em Burgos. no. 60. 18/04/1938.” R/1001(3).

"Informe Político". Despacho no 78. Rio de Janeiro, 18 de Maio de 1938. Do Encarregado de Negócios, José de Carcer ao Ministro de Asuntos Exteriores em Burgos. R/1001 (3)

Informe Político do Encargado de Negócios no Rio de Janeiro (José de Carcer) al Ministro de Asuntos Exteriores em Burgos. no. 149. 05/10/1938.” AMAE, R/1001(3).

Nota do Subsecretario de Negocios al Ministro de Interior e al Servicio Nacional de Propagada em Burgos. no 51558. 20/09/1938. AMAE, R/1001 (3).

Informe enviado por R. M. de Pujadas al Ministro de Asuntos Exteriores em Burgos." 13/10/1938 AMAE, R/1001(3).

“Comunicação enviada pelo Ministerio de Hacienda al Subsecretario de Relaciones Exteriores em Burgos." 10/08/1938. AMAE, R/1001(3).

"Comunicação enviado pela Secretaria de Relaciones Exteriores al Secretario General de S.E. el Jefe de Estado (Seción de Donativos) em Burgos. no. 4256. 20/12/1937. AMAE R/1001 (3) “Comunicação enviado pelo Secretario General de S.E. el Jefe de Estado (Seción de Donativos) al Secretario General de S.E. el Jefe de Estado em Burgos. 07/01/1937. AMAE R/1001 (3) Carta enviada pelo American Friends Service Comittee (David Blickenstaff e Paul Bowman) na Filadélfia ao Subsecretário de Relações Exteriores. 20/12/1938. R/1001(3)

"Sobre donativo 10 mil sacas de café Cruz Vermelha Norteamericana." Do Encarregado de Negócios no Rio de Janeiro (José de Carcer) ao Ministro de Assuntos Exteriores em Burgos. no. 181. 06/12/1938. AMAE, R/1001(3).

"Sobre donativo este Gobierno 10 mil sacas de café." Do Encarregado de Negócios no Rio de Janeiro (José de Carcer) ao Ministro de Assuntos Exteriores em Burgos. no. 171. 08/11/1938. AMAE, R/1001(3).

Do Quartel General do Generalíssimo ao Subsecretário de Assuntos Exteriores. no. 10.717. 27/11/1938. AMAE, R/561

“Telegrama.” Do Encarregado de Negócios no Rio de Janeiro (José de Carcer) ao Ministro de Assuntos Exteriores em Burgos. no. 10. Cifrado. 02/12/1938. AMAE, R/1001(3).

"Noticia envio café Brasil para Zona Roja." Do Encarregado de Negócios do Governo Nacional da Espanha no Brasil (José de Carcer) ao Ministro de Assuntos Exteriores em Burgos. no. 148. 05/10/1938. AMAE, R/1001(3).

“Telegrama cifrado". Do Encarregado de Negócios Fernando Morales Llamas ao Ministro de Estado., nº 21. 03-10-1937. Rio de Janeiro. 
Oficio do Chanceler encarregado do Consulado espanhol em Porto Alegre, Alvaro Raya Ibãnez, ao Secretário de Relações Exteriores do Governo de Burgos. "Dando cuenta orientación imprimida a la gestión del firmante como Encargado de este Consulado, interessando instrucciones." Oficio nº10, 8 de Dezembro de 1936. Porto Alegre.

Do Encarregado de Negócios, José de Carcer ao Ministro de Asuntos Exteriores em Burgos."Informe Político". Despacho nº 78, 18 de Maio de 1938. Rio de Janeiro.

Do Encarregado de Negócios Fernando Morales Llamas ao Ministro de Estado. "Informe político". 23-10-1937. Rio de Janeiro.

Do Encarregado de Negócios, José de Carcer ao Ministro de Asuntos Exteriores em Burgos."Informe Político". Oficio n 46. 31 de Março de 1938. Rio de Janeiro.

Do Encarregado de Negócios, José de Carcer ao Ministro de Asuntos Exteriores em Burgos. “Informe Político". Oficio no 60. Rio de Janeiro, 18 de Abril de 1938.

Do Subsecretario de Negocios ao Ministro de Interior e ao Servicio Nacional de Propaganda em Burgos. "Nota n ${ }^{\circ} 51558 ” .20$ de Setembro de 1938.

Da embaixada espanhola no Rio de Janeiro ao Ministerio de Asuntos Exteriores. "Informe Político". 17 de Dezembro de 1938.

- NATIONAL ARCHIVES (NARA II) - COLLEGE PARK, MARYLAND, ESTADOS UNIDOS.

\section{General Correspondence of the Department of State - RG 59}

Telegram from Charles A. Bay to American Ambassador, St. Jean de Luz. January 9, 1936. "Political Report: The Political Situation in Seville. From Consulate in Seville (Charles A. Bay) to Embassy in San Sebastián. July 18, 1936".

"Telegram from Consulate in Seville (Charles A. Bay) to Department of State. No. 3. August 3, 1936.

"Telegram from Consulate in Seville (Charles A. Bay) to Secretary of State. Strictly Confidential. No. 4. August 9, 1936.

"From Consulate in Seville (Charles A. Bay) to the Department of State. Military uprising in Seville and vicinity. Confidential. August 26, 1936. 
"Telegram from Consulate in Seville (Charles A. Bay) to Departament of State. Strictly Confidential. August 12, 1936.

"Telegram from Consulate in Seville (Charles A. Bay) to Departament of State. November 27, 1936.

"Telegram from Consulate in Seville (Charles A. Bay) to Departament of State. Srictly Confidential. November 29, 1936.

"Telegram from Consulate in Seville (Charles A. Bay) to Departament of State. December 30, 1936.

"Brazilians Relations with the Barcelona Government." Do Embaixador dos Estados Unidos no Rio de Janeiro (Jefferson Caffery) ao Secretário de Estado. No. 861. 05/09/1938. 732.52/3.

"THE FALANGE PARTY OF SPAIN." Western European Section. Coordinator of Information. Memorandum No 5. 15/12/1941

"Relations of Brazilian Government with the Barcelona Government." Do Embaixador dos Estados Unidos no Rio de Janeiro (Jefferson Caffery) ao Secretário de Estado. Strictly Confidential. No. 921. 26/09/1938. 732.52/6.

“CURRENT ATTITUDES IN SPAIN". Psychology Division. Coordinator of Information. Divisional Report No $15.12 / 03 / 1942$.

"Relations of Brazilian Government with the Barcelona Government." Do Embaixador dos Estados Unidos no Rio de Janeiro (Jefferson Caffery) ao Secretário de Estado. Strictly Confidential. No. 921. 26/09/1938. 732.52/6.

"Spanish Falange". Office of Naval Intelligence. 28/10/1942. 852.202/7. 


\section{REFERÊNCIAS BIBLIOGRÁFICAS}

ACTAS DEL CONGRESO INTERNACIONAL. El Régimen de Franco (1936-1975). Madrid: s/l, 1993.

AGUIAR, Cláudio. Os espanhóis no Brasil. Rio de Janeiro: Tempo Brasileiro, 1991.

AIETI. Elementos para una renovada política iberoamericana: España y América Latina en el sistema internacional. Madrid: AIETI, 2000.

ALBUQUERQUE, José Augusto Guilhon (org.). Sessenta Anos de Política Externa Brasileira (1930-1990) volume I: Crescimento, modernização e política externa. São Paulo: Cultura Editores Associados/NUPRI-USP, 1996.

ACCIOLY, Hildebrando, NASCIMENTO E SILVA, G. E. \& CASELLA, Paulo Borba. Mnaul de Direito Internacional Público. 20a. Edição. São Paulo: Saraiva, 2012.

ALMEIDA, Paulo Roberto de. “Brasileiros na Guerra Civil Espanhola, 1936-1939” In: Revista de Sociologia e Política. Curitiba, UFPR, ano 4, no. 12, junho de 1999, pp. 35-66.

ALPERT, Michael. A new international history of the Spanish Civil War. $2^{\circ}$ ed. New York: Palgrave Mcmillan, 2004.

AYLLÓN PINO, Bruno. Las relaciones entre Brasil y España ponderadas desde la perspectiva de la política exterior brasileña (1979-2000). Madrid: Tesis Doctoral, Universidad Complutense de Madrid, 2004.

BANDEIRA, Luiz Alberto Moniz. Brasil, Argentina e Estados Unidos: Conflito e integração na América do Sul (Da Tríplice Aliança ao Mercosul 1870-2003). Rio de Janeiro: Revan, 2003. Estado Nacional e Política Internacional na América Latina: $O$ continente nas relações Argentina - Brasil (1930-1992.). 2a . edição. São Paulo: Ensaio, 1995 . Formação do Império Americano: da guerra contra a Espanha

à guerra no Iraque. 3a . Edição. Rio de Janeiro: Civilização Brasileira, 2009. - Presença dos Estados Unidos no Brasil (Dois séculos de história). $2^{\mathrm{a}}$ edição. Rio de Janeiro: Civilização Brasileira, 1978.

BARBOSA, Wilson do Nascimento. Balanço da Economia Brasileira, 1940-1980. São Paulo: LCTE Editora, 2006.

BATTIBUGLI, Thaís. A militância antifascista: comunistas brasileiros na Guerra Civil Espanhola (1936-1939). São Paulo: Dissertação de Mestrado, Universidade de São Paulo, 2002. 
BENNASSAR, Bartolomé. La guerre d'Espagne et sés lendemains. Paris: Perrin, 2004.

BEEVOR, Antony. La Guerra Civil Española. Barcelona: Crítica, 2005.

BRANCATO, Sandra Maria Lubisco. “As relações Brasil/Espanha na transição para o Estado Novo.” In: Estudos Ibero-Americanos, XIII(2), 1987, pp. 151-160.

BROUÉ, Pierre. A Revolução Espanhola, 1931-1939. São Paulo: Perspectiva, 1992.

BROUÉ, Pierre \& TÉMINE, Emile. La Revolución y la guerra de España. Mexico D.F.: Fondo de Cultura Económico, 1989.

CALLEJA, Eduardo G. La violencia política y la crisis de la democracia republican (19311936). Hispania Nova: Revista de Historia Contemporánea, número 1, 1998-2000.

CAMARGO, Fernando F. De. O ideário falangista de José Antonio Primo de Rivera (19311939). São Paulo: Dissertação de Mestrado, PUC-SP, 2002.

CARONE, Edgard. A República Nova (1930-1937). São Paulo: DIFEL, 1974.

CARONE, Edgar. A segunda república (1930-1937). São Paulo: Difel, 1978.

CARONE, Edgar. O Estado Novo (1937-1945). Rio de Janeiro: Difel, 1977.

CARR, Edward. Vinte anos de crise 1919-1939. Brasília: Editora da Universidade de Brasília, 1981.

CERVANTES, Ángel \& PEREIRA, Juan Carlos. Relaciones Diplomáticas entre España y America Latina. Madrid: Editorial Mapfre, 1992.

CUEVAS, Pedro C. González. Historia de las derechas españolas: De la Ilustración a nuestros días. Madrid: Biblioteca Nueva, 2000.

DANESE, Sérgio. Diplomacia Presidencial: História e Crítica. Rio de Janeiro:Topbooks, 1999.

DINH, Nguyen Quoc, DAILLIER \& PELLET, Alain. Direito Internacional Público. 2a. Ed. Lisboa: Fundação Calouste Gulbenkian, 2003.

EICHENGREEN, Barry. Hall of Mirrors. The Great Depression, The Great Recession and the uses - and misuses - of History. New York: Oxford University Press, 2015.

FAUSTO, Boris \& DEVOTO, Fernando J. Brasil e Argentina: um ensaio de história comparada (1850-2002). São Paulo: Editora 34, 2004.

FONTANA, Josep. España bajo el franquismo. Barcelona: Crítica, 1986.

. História: análise do passado e projeto social. Bauru: EDUSC, 1998.

FRIEDMAN, Max Paul. Nazis and Good Neighbors: The United States Campaign against the Germans of Latin América in World War II. Cambridge: Cambridge University Press, 2003. 
GÓMEZ, ESCALONILLA, Lorenzo D. Diplomacia franquista y politica cultural hacia Iberoamerica, 1939-1953. Madrid: Consejo Superior de Investigaciones Científicas, 1988.

GÓMEZ, ESCALONILLA, Lorenzo D. Imperio de papel. Acción cultural y política exterior durante el primer franquismo. Madrid: Consejo Superior de Investigaciones Científicas, 1992. HOBSBAWM, Eric. A Era dos Extremos. São Paulo: Cia das Letras, 1995. . Nações e Nacionalismo desde 1870: programa, mito e realidade. Rio de Janeiro: Paz e Terra, 1990. Sobre História. São Paulo: Cia das Letras, 1998.

IBÁRRURI, Dolores et al. Guerra y Revolución em España (1936-1939). Moscú: Editorial Progreso, 3 tomos, 1967.

JACSKON, Gabriel. La República española y la Guerra Civil. 2a. Ed. Barcelona: Grijalbo, 1976.

JACKSON, Gabriel. "The Spanish Popular Front, 1934-7” In: Journal of Contemporary History, Vol. 5, No. 3, Popular Fronts (1970).

JIMÉNEZ REDONDO, Juan Carlos. "La política del bloque ibérico: las relaciones hispanoportuguesas (1936-1949). Mélanges de la Casa de Velázques (MCV), 1993, t. XXIX (3).

LEUCHTENBURG, William (org.). O Século Inacabado: A América desde 1900. Rio de Janeiro: Zahar Editores, vol. 2, 1976.

MARTINEZ RUIZ, Elena. Guerra Civil, Comercio y Capital Extranjero. El sector exterior de la economía española (1936-1939). Estudios de História Económica, no. 49. Madrid: Banco de España, 2006.

MARX, Karl. O Capital. Crítica da Economia Política. Livro Primeiro. O Processo de Produção do Capital. Tomo 1. São Paulo: Nova Cultural, 1996.

MARX, Karl \& ENGELS, F. Escritos sobre España. Extractos de 1854. Madrid: Editorial Trotta/Fundación de Investigaciones Marxistas, 1992.

MATTHEWS, Herbert. Metade da Espanha Morreu: uma reavaliação da Guerra Civil Espanhola. Rio de Janeiro: Civilização Brasileira, 1975.

MAZZUOLI, Valerio de Oliveira. Curso de Direito Inernacional Público. 7a. Edição. São Paulo: Revista dos Tribunais, 2013.

MOMPÓ, Enric. Octubre de 1934. Barcelona: mimeo, 2001.

MOMPÓ, Enric. La Revolución sin cabeza. Barcelona: mimeo, 2001.

MORADIELLOS, Enrique. El reñidero de Europa. Las dimensiones internacionales de la guerra civil española. Barcelona: Ediciones Península, 2001. 
MOTTA, Rodrigo Patto Sá. Em guarda contra o "Perigo Vermelho": o anticomunismo no Brasil (1917-1964). São Paulo: Perspectiva/FAPESP, 2002.

MOURA, Gerson. Autonomia na Dependência: A Política Externa Brasileira de 1935 a 1942. Rio de Janeiro: Nova Fronteira, 1980.

MOURA, Gerson. Sucessos e ilusões: Relações internacionais do Brasil durante e após a Segunda Guerra Mundial. Rio Janeiro: Editora da Fundação Getúlio Vargas, 1991.

NASSER, Reginaldo Mattar. O lugar do Hemisfério na Ordem Mundial: percepções norteamericanas. São Paulo: Doutorado em Ciências Sociais, PUC/SP, 2005.

NADAL, Jordi. El fracaso de la revolución industrial en España, 1814-1913. Barcelona: Ariel, 1975.

NETO, Lira. Getúlio (1930-1945). Do governo provisório à ditadura do Estado Novo. São Paulo: Cia. das Letras, 2013.

PARDO, Rosa. Con Franco hacia el Imperio. La política exterior española en América Latina, 1939-1945. Madri: UNED, 1995.

PARIS, Robert. As Origens do Fascismo. São Paulo: Perspectiva, 1972.

PASTOR, Manuel. Los Orígenes del fascismo en España. Madrid: Tucar, s/d.

PAYNE, Stanley G. Franco y José Antonio: El Extraño Caso del Fascismo Español. Barcelona: Planeta, 1997.

PAYNE, Stanley G. Falange: Historia del fascismo español. Paris: Ruedo Iberico, 1970.

PEREIRA, Juan Carlos (coord.). La política exterior de España (1800-2003): Historia, Condicionantes y Escenarios. 1a. edición. Barcelona: Ariel, 2003.

PRADOS DE LA ESCOSURA, Leandro. De imperio a nación. Crecimiento y atraso económico en España (1780-1930). Madrid: Alianza Editorial, 1993.

PRESTON, Paul. The Coming Of The Civil War: Reform, Reaction and Revolution in The Second Republic. London: Routledge, 1994.

PRESTON, Paul. Franco. A Biography. New York: BasicBooks, 1994.

RAPOPORT, Mario y SPIGUEL, Claudio. Relaciones tumultuosas: Estados Unidos y el primer peronismo. Buenos Aires: Emecé Editores, 2009.

RODRIGUES, Pedro. "Brasileiros na Espanha” In: Temas das Ciências Humanas. São Paulo, volume 9, 1980, pp. 125-128.

SANCHEZ-ALBORNOZ, Nicolás (comp.) La modernización de España, 1830-1930. Madrid: Alianza Editorial, 1987. 
SÁNCHEZ ASIAÍN, José Ángel. La financiación de la guerra civil española. Una aproximación histórica. Barcelona: Crítica, 2012.

SCHOULTZ, Lars. Beneath the United States: a history of U.S. policy toward Latin America. London/Cambridge: Harvard University Press, 1999.

SOUZA, Ismara Izepe de. Caminhos que se cruzam: relações históricas entre Brasil e Espanha (1936-1960). São Paulo: Tese de Doutoramento, Universidade de São Paulo, 2009.

TAMAMES, Ramón. La República/La Era de Franco. Madrid: Alfaguara/Alianza Editorial, 1979.

TENA, Antonio J. Las estadísticas históricas del comércio internacional: fiabilidade y comparabilidade (1890-1960). Estudios de Historia Económica, no. 24. Madrid: Banco de España - Servicios de Estudios, 1992.

TIERNEY, Dominic. FDR and the Spanish Civil War. Neutrality and Commitment in the Struggle that divided America. Durham and London: Duke University Press, 2007.

THOMÁS, Joan Maria. Roosevelt and Franco during the Second World War: from the Spanish Civil War to Pearl Harbor. New York: Palgrave Macmillan, 2008.

TOGLIATTI, Palmiro. Escritos sobre la guerra de España. El testimonio histórico del dirigiente extranjero que más influyó en la lucha contra el fascismo en España. Barcelona: Editorial Crítica, 1980.

TROTSKY, Leon. Escritos sobre España. Paris: Ruedo Ibérico, 1971.

TUÑON DE LARA, Manuel. La II República. Madrid: Siglo Veintiuno, 1976.

TUÑON DE LARA, M. \& NÚÑEZ DE ARENA, M. Historia del movimento Obrero Español. Barcelona: Nova Terra, 1979.

TUÑON DE LARA, Manuel et alii. La Guerra Civil Española. 50 años después. Barcelona: Labor, 1989.

VILAR, Pierre. La Catalogne dans l'Espagne moderne: recherches sur les fondements économiques des structures nationales. Paris: S.E.V.P.E.N., 1962.

VILAR, Pierre. Crecimiento y Desarrollo. Economia e historia. Reflexiones sobre el caso español. Barcelona: Ariel, 1983.

VILAR, Pierre. La guerra civil española. 5ª . Ed. Barcelona: Crítica, 2005.

VILAR, Pierre. A História da Espanha (1936-1939). Rio de Janeiro: Paz e Terra, 1992.

VILAR, Pierre. Oro y moneda en la historia (1450-1920). 3ª . Ed. Barcelona: Ariel, 1974.

VIÑAS, Angel. La Alemania nazi y el 18 de julio. 2a . edición. Madrid: Alianza Universidad, 1977. 
VIÑAS, Angel. En El Combate por la Historia. La República, La guerra civil, el franquismo. Barcelona: Pasado \& Presente, 2012.

VIÑAS, Angel. El escudo de la República. El oro de España, la apuesta soviética y los hechos de mayo de 1937. Barcelona: Crítica, 2010.

VIÑAS, Angel. El honor de la República. Entre o acoso faccioso, la hostilidade britânica y la política de Stalin. Barcelona: Crítica, 2010.

VIÑAS, Ángel. La Otra Cara del Caudillo. Mitos y realidades en la biografía de Franco. Barcelona: Crítica, 2015.

VIÑAS, Angel. La Soledad de la República. El abandono de las democracias y el viraje hacia la Unión Soviética. Barcelona: Crítica, 2006.

VIÑAS, Angel et al. Política Comercial Exterior em España (1931-1975). Madrid: Banco Exterior de España, 1979, 2 vols.

VIÑAS, Angel. La Soledad de la República. El abandono de las democracias y el viraje hacia la Unión Soviética. Barcelona: Crítica, 2010. 
ANEXOS 


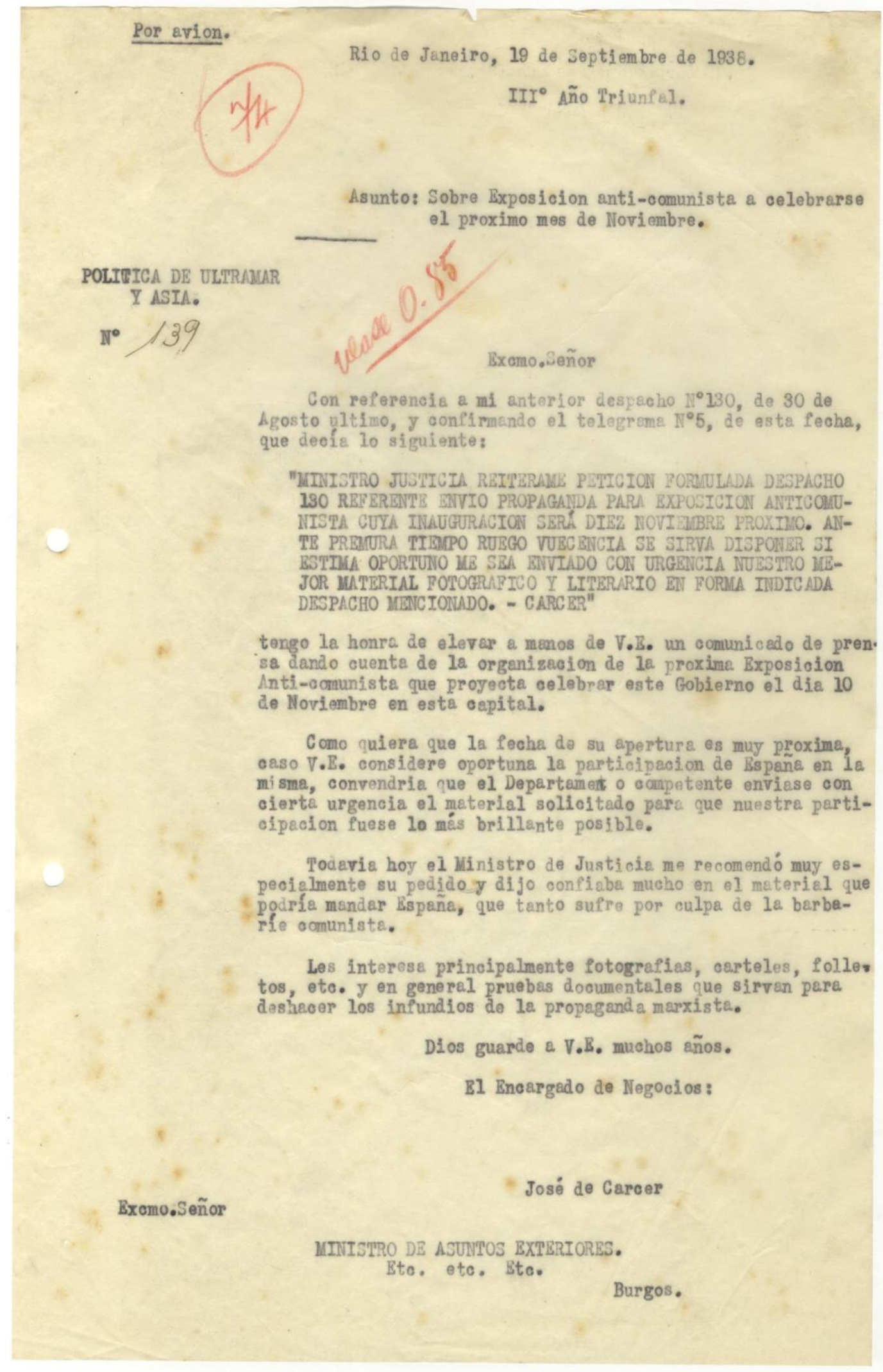


. Beer ob eqdujo ab a .o tiarat eb olя - Is invirt or̂h "III

Bl telegrama a que antes me reliero (si es verídico) es una prueba más de la evolucion sufrida por este pais con relacion a nuestra Causa y que en varias ocasiones

Procuraré arepiguar lo que hay de cierto en este asunto aunoue es más que probable que solo obtendré contestaciones evasivas pues a muchos les he de ser desagradable confesar le verdad?. om xd

Dios guarde a $\mathrm{V} \cdot \mathrm{B}$. muchos anos.

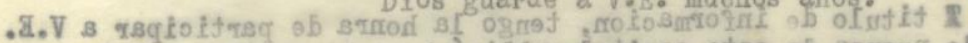

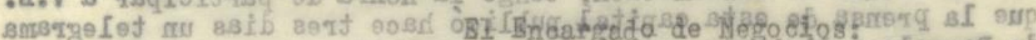

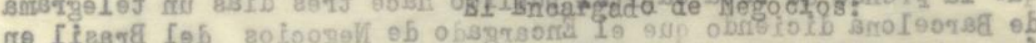

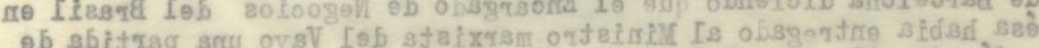
- "îmsqad $\mathrm{s}$ olfix

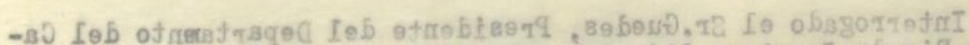

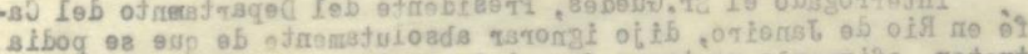

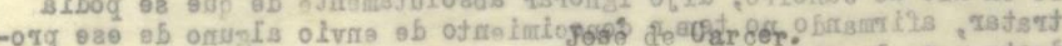
-stor sros BI araq ofoub

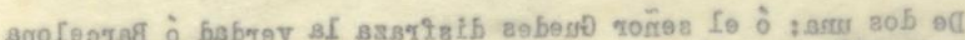

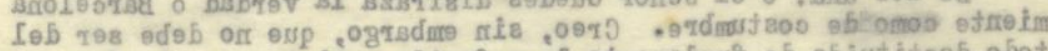

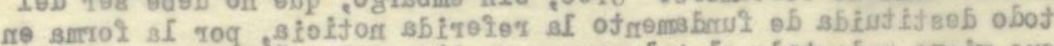

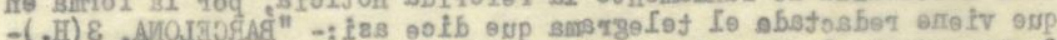

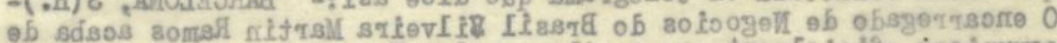

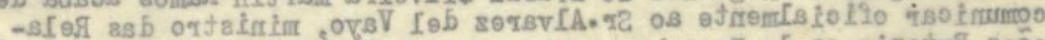

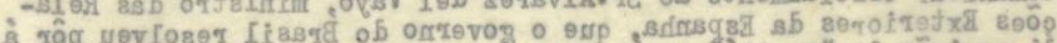

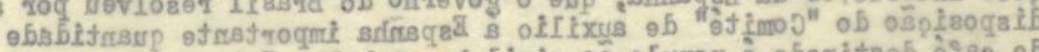

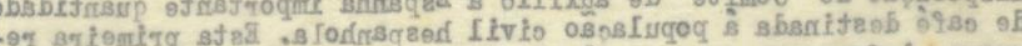
- 0 q

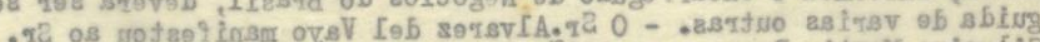

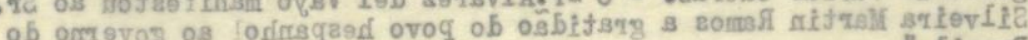

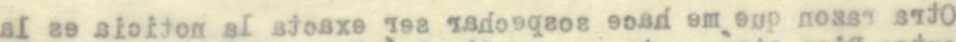

सU.

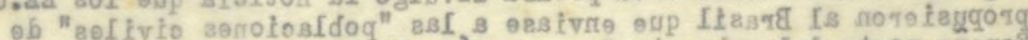

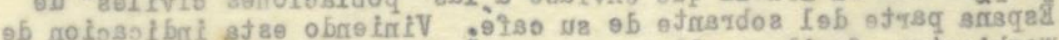

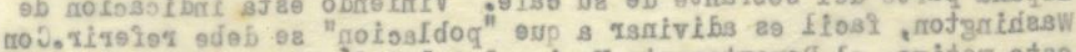

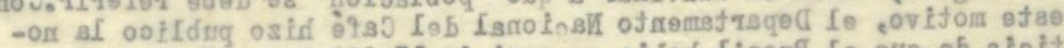

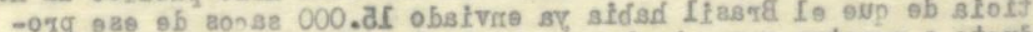
- вveramo a

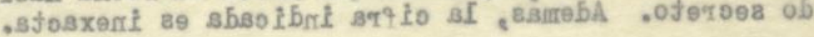

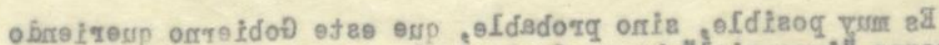

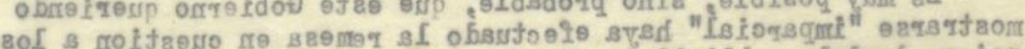

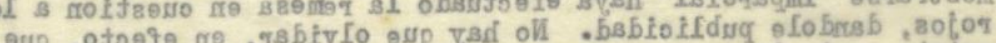

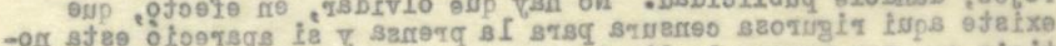

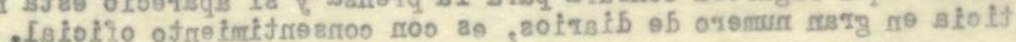

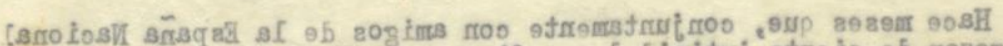

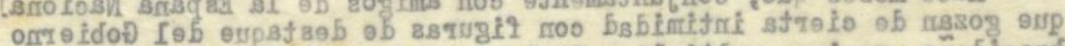

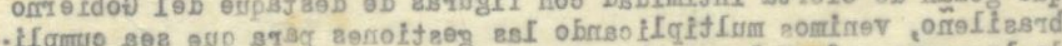
17 mo sea

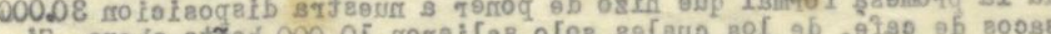

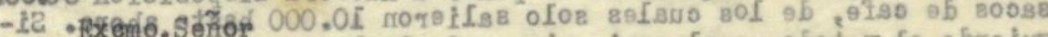

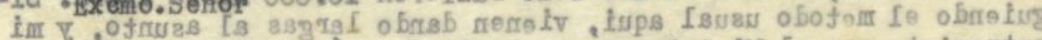

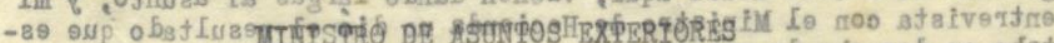
\& \& Burgos 


\begin{tabular}{|c|c|}
\hline $\begin{array}{l}\text { ULT. y ASTA. } \\
\mathbb{N}^{\circ} / 488\end{array}$ & 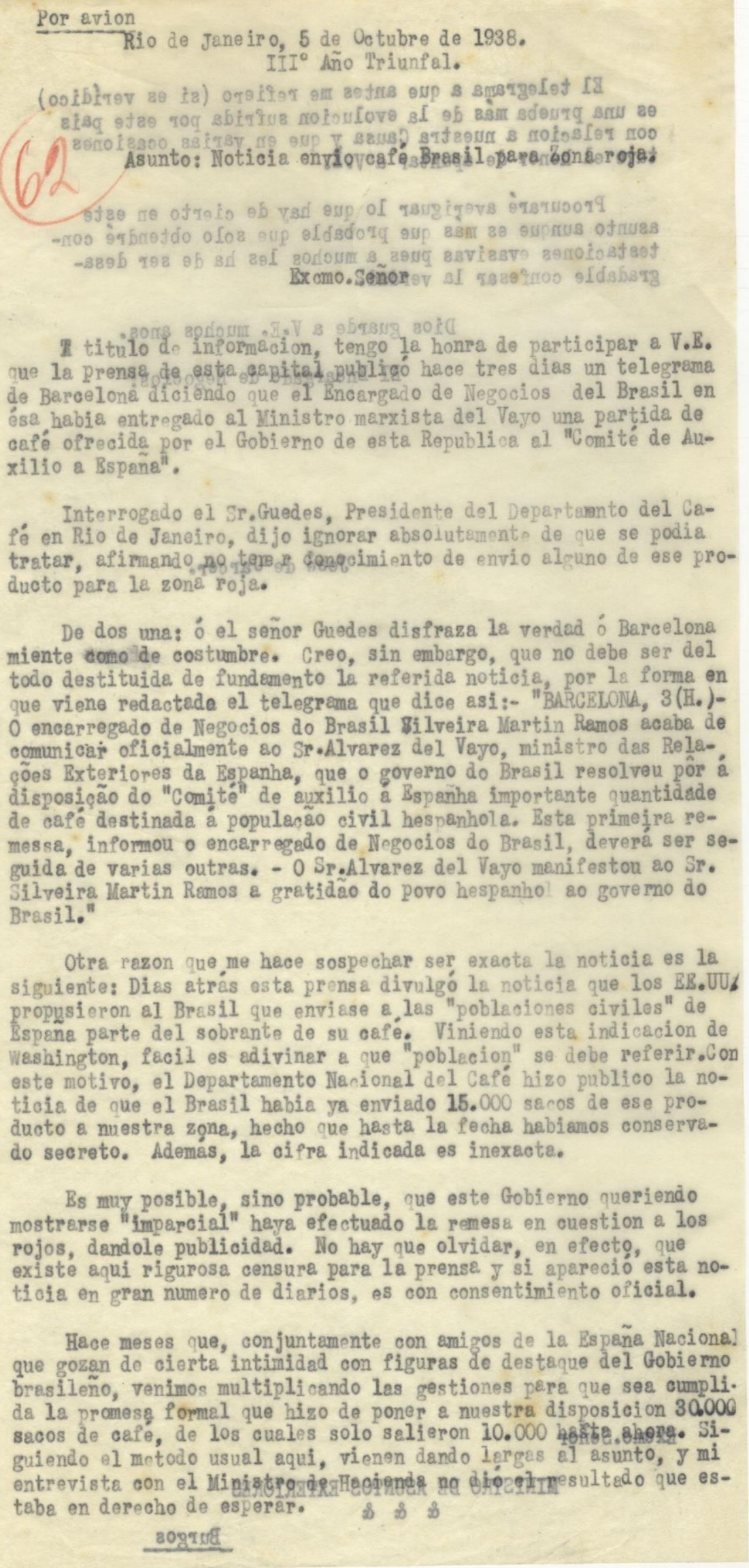 \\
\hline
\end{tabular}




\section{Por avion}

Rio de Janeiro, 8 de Noviembre de 1938.

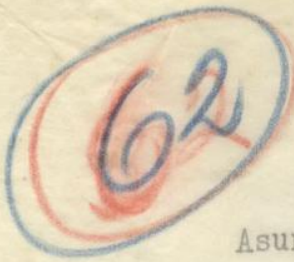
IIIO Año Triunfal.

N@ $|7|$

Asunto: Sobre donativo este Cobierno $10 \mathrm{mil}$ sacas de café.

ULTR.Y ASIA.

\section{Excmo.Señor}

En relacion con mi Despacho No153, de 12 de Octubre proximo pasado, referente a un embarque de café para la zona roja, tengo la honra de informar a V.E. que este Ministro de Hacienda, cumpliendo una resolucion del Presidente de la Republica, autorizó el dia 3 del corriente, al "Departamento Nacional del Café" a conceder un donativo de 10.000 sacos de café para distribuir entre las poblaciones més necesitadas de España, concedien do al mismo tiempo la exencion del pago de impuestos y la entrega al Banco del Brasil de las letras de exporta cion en moneda extranjera referentes a este donativo.

Bste donativo se hizo a raiz del llamamiento que el Presidente Roosevelt lanzó a las Republicas Americanas para enviar socorros a "los españoles que sufren,por intermedio de la Cruz Roja Americana.

Segun informa la Agencia Havas, diche Cruz Roja anuncia que el vapor "ALGIC" cargará en el puerto de Santos 1.320.000 libras-peso de café, of recido por este Gobierno. Este café se embarca para los puertos de Burdeos y el Havre para ser dividido en partes iguales entre las poblaciones civiles de Bspaña.

Dios guarde a $\nabla . \mathbb{B}$. muchos años.

Bl Incargado de Negocios:

\section{José de Carcer.}

\section{Excmo.Señor}

-MINISTRO DE ASUNTOS BXTERIORBS-

$\& \quad \& \quad \&$

Burgos. 


\section{Por avion.}

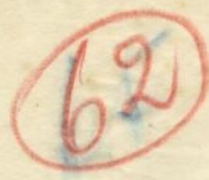

Rio de Janeiro, 16 de Noviembre de 1938.

III Año Triunfal.

Asunto: Sobre envio 10 mil sacos de café.

No $1 / 3$

ULTRAMAR Y ASIA.

Excmo.Señor

Con referencia a mis anteriores despachos y en ultimo tẽenino al №ł71, de 8 del corriente, relativos al embarque de 10.000 sacos de café, que este Gobierno destina a la poblacion civil de España, tengo la honra de informar a V.B. que segun me comunica nuestro Cónsul en Santos, se ha recibido ya en el Departamento Nacional del Café, de dicha ciudad, la autorizacion para proceder a dicho embarque.

La mercancia irá, al parecer, a bordo del "Algic", de la AMERICAN REPUBLICS LINE, que saldrá de este puerto el dia 28 del corriente con destino a los puer. tos de Jacksonville, Norfolk y Baltimore.

Este cargamento de café, segun me informan, debió haber sido embarcad el 27 del pasado Octubre en el "West Imboden", de la antes citada Compañía, que se dirigia a Boston y Philadelphia, pero fué necesario desistir de ello por no haber llegado la autorizacion de embarque.

Dios guarde a $\mathrm{V}: \mathrm{F}$. muchos años.

El Encargado de Negocios:

José de Carcer.

Excmo.Señor

MINISTRO DE ASUNTOS EXTERIORES

\& \& \& Burgos. 
Rio de Janeiro, 6 de Diciembre de 1938.

ULTRAMAR Y ASIA.

N: 187 III\& Año Triunfal.

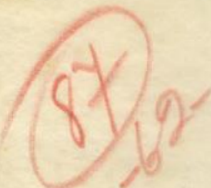

Asunto: Sobre donativo $10 \mathrm{mil}$ sacas de café Cruz Roja Norteamericana.

\section{Excmo.Señor}

En confirmacion a mi telegrama $\mathbb{N}: 10$, de 2 del corriente, contestando al de V.B. No3, de igual fecha, tengo la honra de participar a $\nabla . B$. que segun me fué informado en este Ministerio de Relaciones Bxteriores, han sido embarcadas en el puerto de Santos 10.000 sacas de café con destino a la Cruz Rojạ Norteamericana, los dias 29 y 30 de Noviembre ppdo.

Este donativo lo concedió este Gobierno a pedido de la referida entidad y se destina a las "poblaciones necesitadas de España".

Se dejó al criterio de dicha Cruz Roja, la distribucion de esa partida de café, no interviniendo, por consiguiente, el Gobierno brasileño, en su uiterior reparto.

La mercancia fué embarcada para Nueva York en el vapor "Argentina", de la AMERICAN REPUBLIC LINES.

Dios guarde a V.B. muchos años.

Bl Encargado de Negocios:

José de Carcer.

\section{Excmo.Señor}

MINISTRO DE ASUNTOS EXTERIORES

\& \& \&

Burgos. 
tades personales. Pero de nada sirve el sistema brusco y tenemos aqui mismo el ejemplo de Alemenia que por querer emplearlo está en relaciones muy tirantes y sin Embajador hace muchos meses.

Bl resultado tangible de nuestra recusa $-y$ eso no tiene solucion- vá a ser el siguiente: Recientes leyes muy estrictas obligan a todos los extranjeros que quieren permanecer aqui, a sacer una cartera de identidad expedida por estas autoridades. Para ello deben presentar, entre otros documentos, una cedula expedida por el consulado de su pais que acredite su personalidad y nacionali dad. Ahora bien, estas autoridades no reconocen las cedulas expedidas por nuestra representacion. Hasta aqui, y siempre mediante el. sistema de amistades, hemos obtenido que en algunos casos fuese reconocida, pero ahora vá a ser más dificll. In consecueneia, cientos de nuestros compatriotas simpatizantes y que tienen interés en permanecer en ell Brasil por sus negocios, etc., se van a ver obligados a recurrir a los consulados rojos para que le sean expedidas cedulas personeles. Sin tomar en cuenta lo que esto supone en la recaudacion consular, veremos alejarse de nosotros a muchos que sin ser ardientemente adeptos, sentian cierta simpatia por nuestra Causa.

Wuy lejos de mi pensamiento está el atreverme siquiera a discutir la decision del Consejo de Ministros. Desde el punto de vista moral tiene perfectamente razon, pero como no se puede pensar por ahora en un reconocimiento "de jure", es mi modesto parecer que con un intercambio de Agentes hubiesemos nosotros lucrado mucho más que el Brasil, que no tiene en Bspaña ni subditos ni intereses de importancia.

Dios guarde a V.E. muchos años.

BI Encartado de Nlegocios:

José de Carcer.

Excmo.Señor

MINISTRO DE ASUNTOS BXTIRRIORES

\& \& \& Burgos. 
Rio de Janeiro, 3 de Enero de 1939.

III Año Triunfal.

Ult. y Asia.

Asunto: Sobre intercambio Agentes con el Brasil.

N\& $/$

\section{Bxcmo.Señor}

Tengo el honor de referime en último térnino al te-

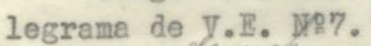

Mi telefreme $\mathbb{N} 180$, de 25 de Noviembre del año proximo pasado, explica como partió de este Gobierno la iniciativa de un intercambio de Agentes con el nuestro.

Transmitida la propuesta, $\nabla . B$. tuvo a bien indicar que aceptaria bajo ciertas condiciones, indicadas en el telegrama $N 22$, de 27 de Noviembre ultimo.

Con esos datos, redacté un Memorandum que debia servir de base para iniciar las negociaciones.

Para decir la verdad, pensé en un principio que este cobierno no acepteria la totalidad de nuestros exigencias pues tenia la impresi on que deseaba un agente permanemte comercial, como el de chile.

Pero fueron desarrollandose las conversaciones en una atmosfera favorable. Despues de varias entrevistas con el Secretario General del Ministerio de Relaciones Exteriores, tanto on su Departamento como en casa de amigos comunes, este Gobierno acabó aceptando todas las condiciones de V.E.: Exclusion dè todo caracter comercial; agente con cartas de gabinete; inmunidad diplomatica; franquicias; derecho de nombrar sub-agentes con funciones con sulares; ete. y naturalmente, validez ante estas autoridades de todos los documentos expedidos por nosotros. En resumen, era un reconocimiento "de facto" total.

pero desde el momento en que nuestro Consejo de Ministros estima preferible no proceder al intercambio de Agentes, me abstendré como es natural de tocar en el asun to y procuraré por todos los medios suavizar el resentimiento que forzosamente se manifestará por parte de estas Autoridades. In efecto, Exomo.Señor, ni ol Brasil ni el brasileño séasemeja a los demás paises amerícanos. Bl natural dé este pais es susceptible en extremo y de él puede conseguirse mucho por metodos suaves y cultivando amis 
se entregaron a Rusia, fué por venderles, aúnque a precios prohibitivos, el armamento y material que necesitaban y que les era negado por los demás paises.

Mientras conferiaban llegó a sus oidos la noticia de la entrada de Nuestras tropas en Barcelona, se le humedecieron los ojos y expresó su tristeza en formalalgo teatral, cosa que aquí siempre impresiona $\mathrm{y}$ produce buen efecto.

No se conocen todavia sus propositos, pero no seria de extrañar que embarease el próximo día 29 para los Estados Unídos en el vapor "New Amsterdam", aprovechando la oportunidad de poder viajar junto con este luinistro de Relaciones Exteriores que va a Wanshington para conferenoiar con el Presidente Roosevelt. En mi proximo despacho continuaré informando a V.E. Dios guarde a.V.E. muchos años. El Encargado de Negocios

\section{José de Cárcer}

Excmo. Señor

MINISTRO DE ASUNTOS EXTERIORES

\&

\&

\&

BURGOS 


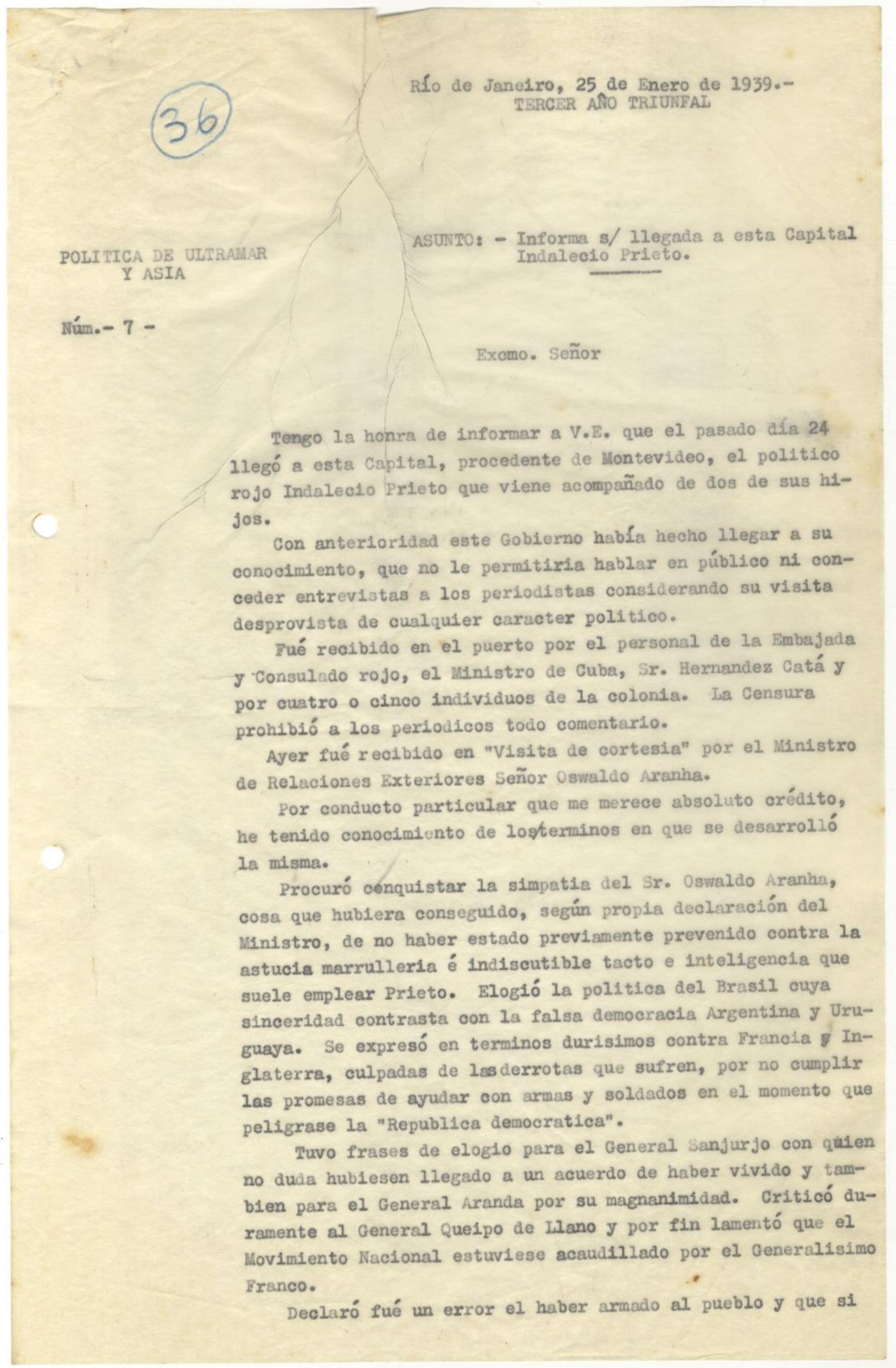


nıo de janeiro, $ょ$ ae redrero de lysy

III Año Triunfal.

Asunto: Deseo Brasil desarrollar intercambio comercial con la España Nacional.

1ㅇ 8

Ult. y Asia. Comercio.

Excmo.Señor

Persona que goza de la intimidad del Presidente de la Republica vino a decirme que seria el deseo del Sr.Getulio Vargas el ver desarrollarse intensamente el intercambio entre Brasil y la España Nacional. Este país, añadió, èstá dispuesto a fornecernos de materias primas como algodon por ejemplo, y está pronto a darnos las mayores facilidades de pago.

Mi interlocutor sugerió el envio a Rio de Janeiro de un técnico de nuestro Departamento de Industria y Comercio para estudiar la cuestion sobre el terreno..

Todo lo cual tengo la honra de poner en el superior conocimiento de V.B. para los efectos que estime oportunos.

Dios, guarde a V.E. muchos años.

Bl Encargado de Negocios:

José de Parcer.

Excmo.Señor

MINISTRO DE ASUNTOS EXTERIORES

\& \& \& \&

Burgos. 
la conveniençia de teper la opinión de una ú otra Representacion, le fue contestado que no teniamos que nada que ver con eso.

Añadire que la Camara todavia ostenta en su balcó el escudo del extinto régimen.

Ante esta situación, ante la resistencia de toda esa gente que no quieręn ponerse a mal unos con otros y para quienes la nocion de dignidad y Patria son meras palabras sin sentido, me he visto obligado aesscri bir una carta a Nanuel babanellas en la que hago resal tar

$L^{\circ}$ - Que la Camara de Comercio no puede, ostentar el titulo de "oficial" sin expresa autorización de nues organismos competentes (ilinisterio de Industria y Comerc10).

$2^{\circ}-$ Que la presencia de España como secretario es inadmisible y que dudo que nuestras Autoridades 10 aprueben.

$3^{\circ}$ - Dandole un plazo de 48 horas para retirar el escudo dell balcón. Pasado ese plazo lo hare retirar po la policia.

Esta es la situación actual. A medida que se va--yan modificando, me apresurare a informar a V.E.

Dios guarde a V.E. muchos años EI Encargado de Negocios

José de Cárcer

Excmo. Señor

Ministro de Asúntos Exteriores

BURGOS 
Por Avión

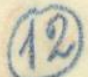

Ult.y Asia

$\mathbb{N}^{\circ} 42$
Rio de Janneiro, 18 de Nayo de 1939

Año de la Victoria

Asúnto: sobre Camara de Comercio Española en Rio de Janeiro.

Como VR. sabe, la Camara de Comercio Española en Rio de Janeiro, cuyo presidente era Antonio España Parames, durante todo el tiempo del glorioso lovimiento Nacional se mantuvo al servicio de los rojos. Su presi dente firmo un acto de adhesion a los marxistas y,era asiduo frecuentador de las representaciones diplomáticas y consulares de esa gente en esta Capital.

Según me dicen, Antonio España Parames y otros miembros de la directiva de la Camara de comerc10, tuvieron la falta de pudor de enviar a V.E. un telegrama de felicitaciones a raiz do la entrada de nuestras tropas en lladrid.

Desde entonces, España Parames venia haciendo toł

da clase de intrigas-pan de cada dia entre la colonia para quedarse en la Camara de Comercio.

con objeto de tẹrmi nar con estas anomalias, cité a los compatriotas más destacados, (por decirlo asi) a comparecer a esta Embajada. Al propio tiempo pedf al abogado Sr. D'Utra para que asistiese a la reunion, ca so fuese necesario hacer alguna consibte de caracter juridico.

Acudieron 33 personas a quienes hice ver la necesidad de incautarnos de la camara de comercio, limpian dola de los elementos que tan contrarios nos fueron. Todo el mundo parecia de acuerdo, tanto es as I $^{\circ}$ que se redactó la siguiente acta que todos firmanos: "ACTA - Reunidos en esta Embajada de España en la fecha de hoy para discutir asuntos relacionados con la Camara Bepeñoiacdo comercio e Industria, de esta capital, los infrascritos han decidido nombrar una comISIIO compuesta de los Señores, lianuel Barreiroș Cabanelas, Joaquin Vivas Martin, José Fernandez González, Fel1sindo Carreiro y Zeferino Gondar, encargada de tramitala Incautacion de la c1 tada Camara Espanola de Comere1 - Industria, que hasta ahora se habia mantenido al ser vicio del Gobierno rojo.

Quedó entendido que si estas gestiones no dieran resultado, esta Embajada acudiria a todos los medios legales para obtener dicha incautacion cuanto antes.

Y para que conste, firmamos la presente en dos ejemplares.

A los pocos dias, cual taélué mi extrañeza al saber que la citada Comisión se habia incautado de la Camara de Comercio, manteniendo a España como guardian provisorio. Despues de 10 cual convocaron una Asamblea en e1 Centro Gallego, donde solo acudieron, me dicen, unas veinte personas y eligieron la directiva de la Ca mara, siendo Presidente lianuel Cahanelas y Secretario el mencionado España.

Todo esto Pue hëcho naturalmente sin consultar ni la embajada ni el consulado y cuando alguien hizo nota: 


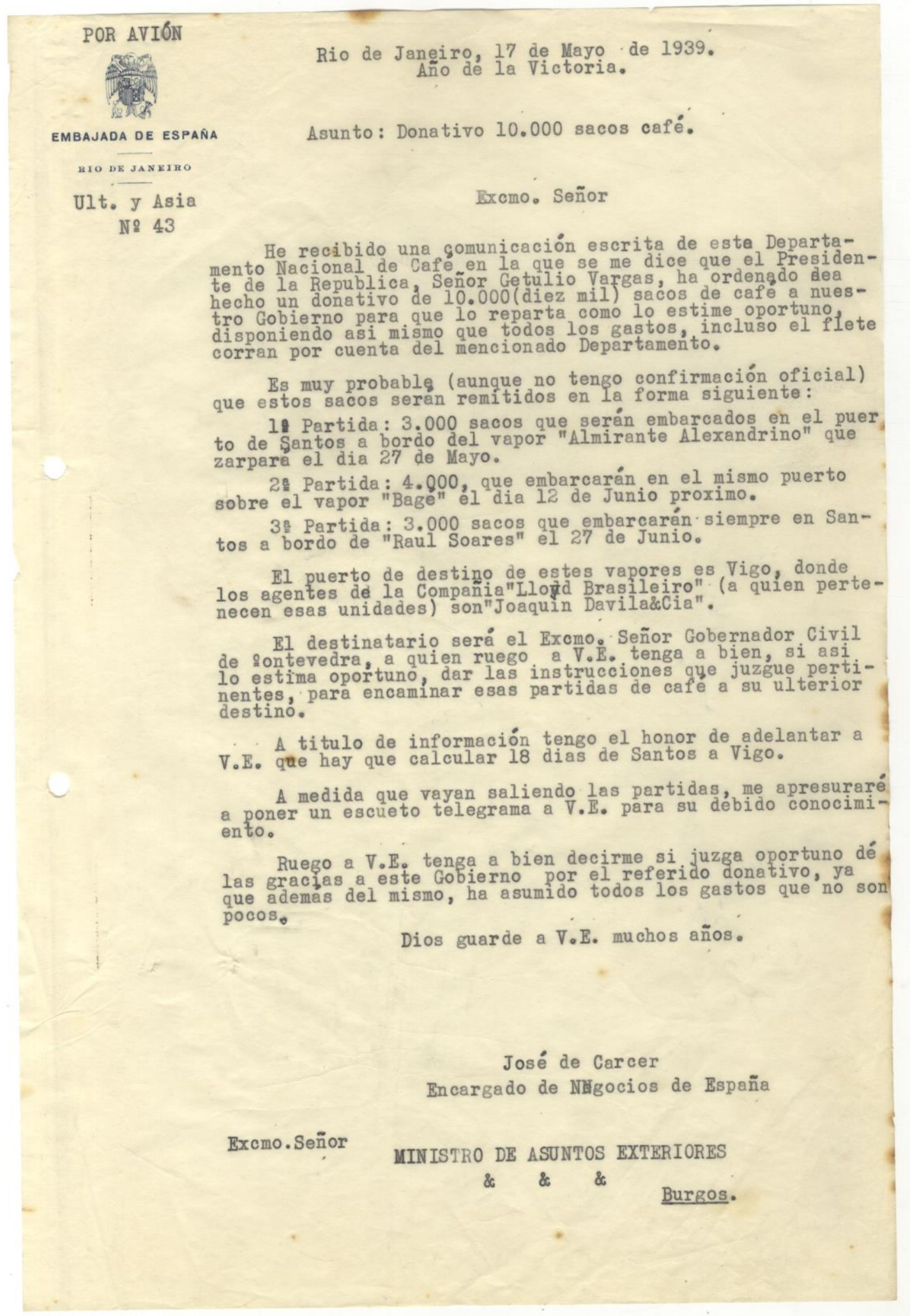




\section{Río de Janeiro, 30 de Agosto de 1938.- TERGER ANOO TRIUNFAL}

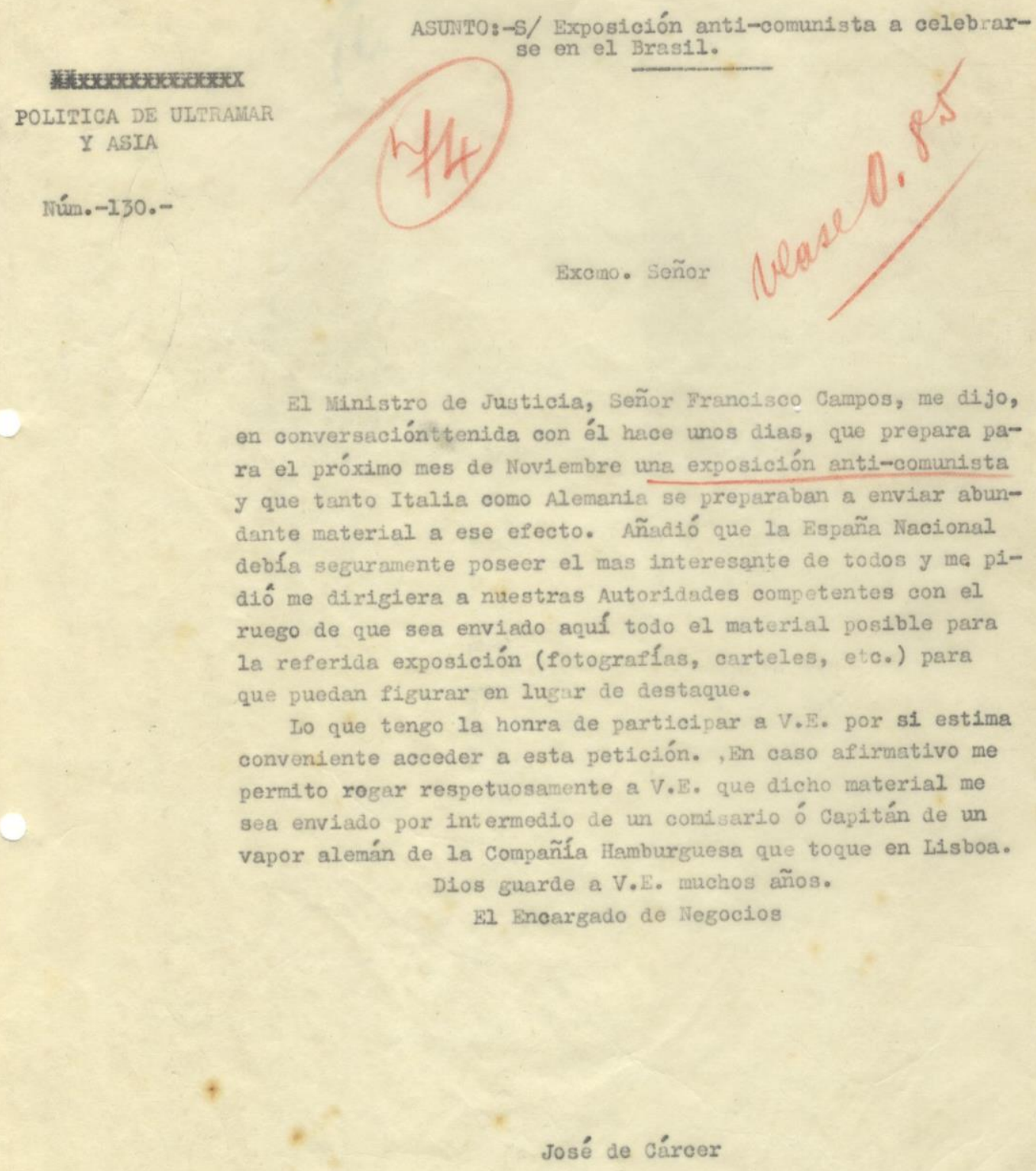

Excmo. Señor

MINISTRO DE ASUNTOS EXTERIORES

\&

8

BURGOS 
